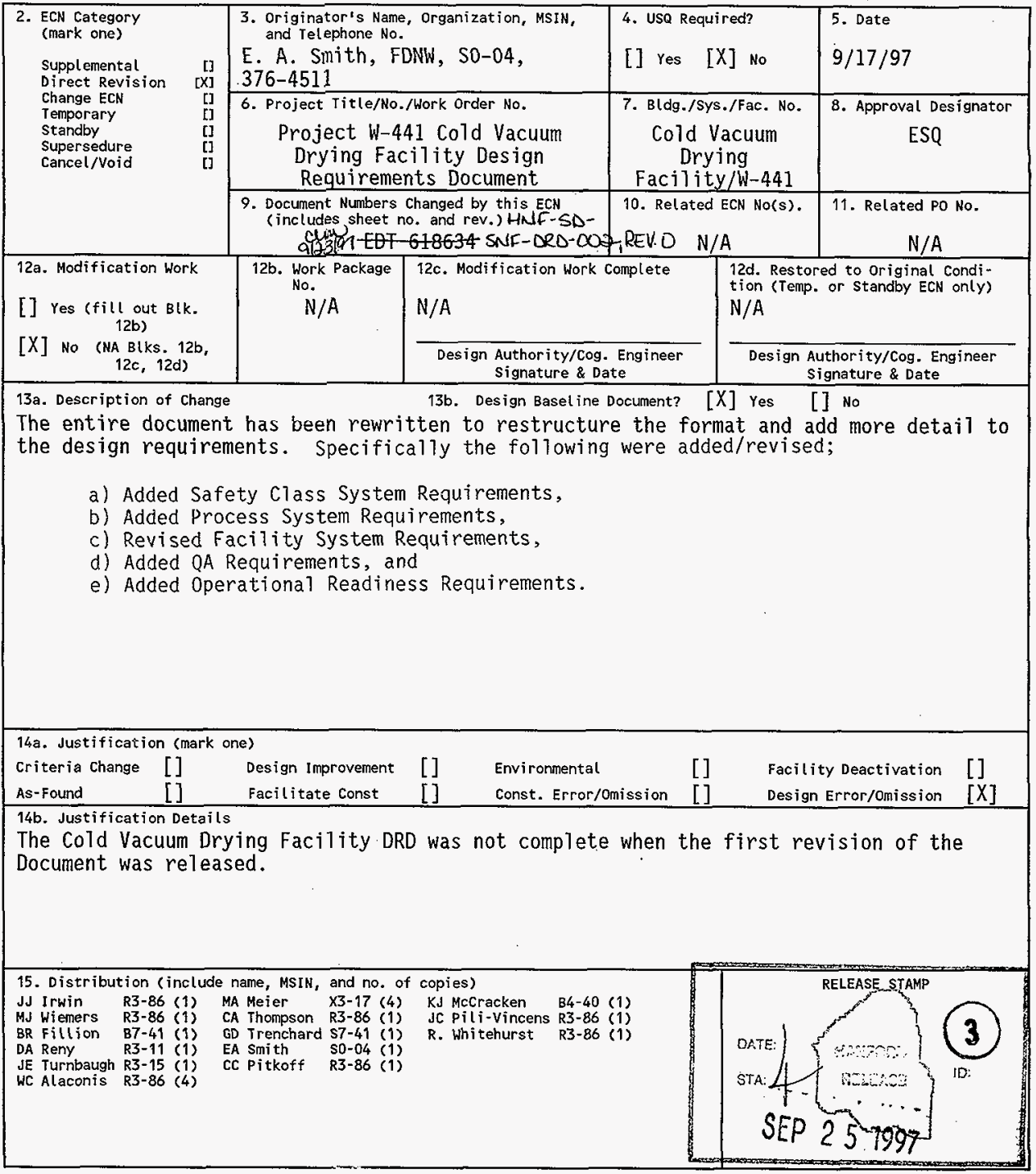

A-7900-013-2 (05/96) GEF095 


\section{ENGINEERING CHANGE NOTICE}

Page 2 of 2

\begin{tabular}{l|l} 
16. Design & 17. Cost Impact
\end{tabular}

Verification

Required

[] Yes [X] No
ENGINEERING

Additional [] \$

[] $\$$

CONSTRUCTION

19. Change Impact Review: Indicate the related documents cother than the engineering documents identified on side 13 that will be affected by the change described in Block 13 . Enter the affected document number in Block 20. SDD/DD

Functional Design Criteria

Operating Specification

Criticality Specification

Conceptual Design Report

Equipment Spec.

Const. Spec.

Procurement Spec.

Vendor Information

OM Manual

FSAR/SAR

Safety Equipment List

Radiation Work Permit

Environmental Impact Statement

Environmental Report

Environmental Permit
[]

[]

[]

[]

[]

[]

[]

[]

[]

[]

[]

[]

[]

[]

[]
Seismic/Stress Analysis

Stress/Design Report

Interface Control Drawing

Calibration Procedure

Installation Procedure

Maintenance Procedure

Engineering Procedure

Operating Instruction

Operating Procedure

Operational Safety Requirement

IEFD Drawing

Cell Arrangement Drawing

Essential Material Specification

Fac. Proc. Samp. Schedule

Inspection Plan

Inventory Adjustment Request
[]

[]

[]

[]

[]

[]

[]

[]

[]

[]

[]

[]

[]

[]

[]
18. Schedule Impact (days)

Improvement

Delay
[]

20. Other Affected Documents: (NOTE: Documents (isted below will not be revised by this ECN.) Signatures below indicate that the signing organization has been notified of other affected documents listed below. Document Number/Revision

Document Number/Revision

Document Number Revision

$\mathrm{N} / \mathrm{A}$

21. Approvals

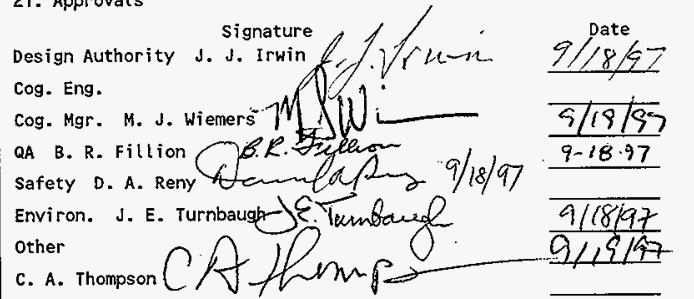

Signature

Date

Design Agent

Tank Calibration Manual

Health Physics Procedure

Spares Multiple Unit Listing

Test Procedures/Specification

Component Index

ASME Coded Item

Human Factor Consideration

Computer Software

Electric Circuit Schedule

ICRS Procedure

Process Control Manual/Plan

Process Flow Chatt

Purchase Requisition

Tickler File

PE

QA

Safety

Design

Environ.

other

\section{DEPARTMENT OF ENERGY}

Signature or a Control Number that tracks the Approval signature

ADDITIONAL 


\title{
Cold Vacuum Drying Facility Design Requirements
}

\author{
J. J. Irwin
}

Numatec Hanford Co., Richland, WA 99352

U.S. Department of Energy Contract DE-AC06-96RL.13200

EDT/ECN : 642492

Org Code: 2T640

B\&R Code: $39 \mathrm{EW} 70400$

UC: 510

Charge Code: LH062

Key Words: CNDF

Total Pages: $3 \pm 6$ 317

Abstract: This release of the Design Requirements Document is a complete restructuring and rewrite to the document previously prepared and released for project $W-441$ to record the design bas is for the design of the Cold Vacuum Drying Facility.

TBD information will be issued at a later date.

TRADEMARK DISCLAIMER. Reference herein to any specific comercial product, process, or service by trade name, trademark, manufacturer, or otherwise, does not necessarily constitute or imply its endorsement, recommendation, or favoring by the United states Government or any agency thereof or its contractors or subcontractors.

Printed in the United States of America. To obtain copies of this document, contact: Document Control Services, P.O. Box 950, Mailstop H6-08, Richland WA 99352, Phone (50́9) 372-2420; Fax (509) 376-4989.
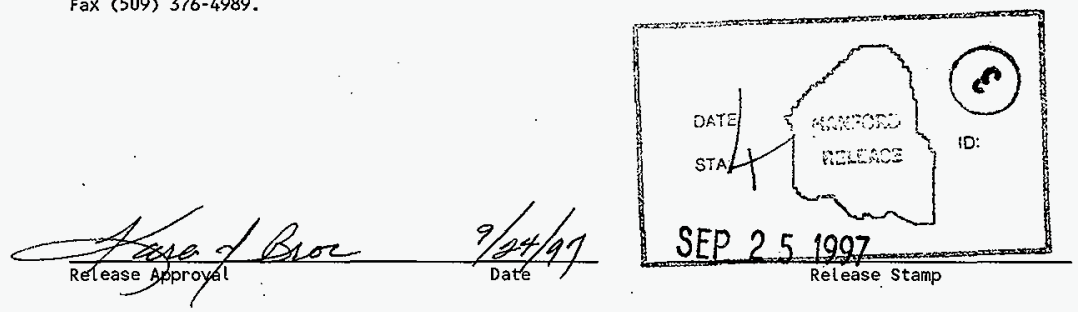

\section{Approved for Public Release}




\section{RECORD OF REVISION}

(1) Document Number

HNF-SD-SNF-DRD002

(2) Titie

Project W-441 Cold Vacuum Drying Facility Design Requirements Document

CHANGE CONTROL RECORD

(3)

Revision

(4) Description of Change - Replace. Add, and Delete Pages

$0 \quad$ (7) EDT 618634

${ }^{1}$ RS
Replace table of contents with updated version.

Rewrite of entire drd. . See ECN 642492
Authorized for Release

(5) $\operatorname{Cog}$. Engr.

(6) Cog. Mgr, Date

Rew ite of entire drd. see ecN 642492

\begin{tabular}{|l|l|}
\hline & \\
\hline &
\end{tabular}


HNF-SD-SNF-DRD-002 REV 1

This page intentionally left blank. 


\section{CONTENTS}

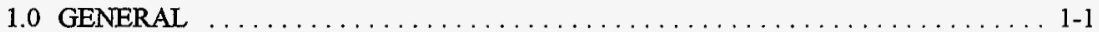

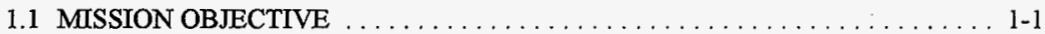

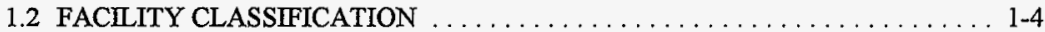

1.3 SCOPE OF THE DESIGN REQUIREMENTS DOCUMENT $\ldots \ldots \ldots \ldots \ldots \ldots 1-5$

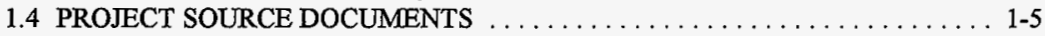

1.4.1 Process and Facility Source Documents . . . . . . . . . . . . . 1-7

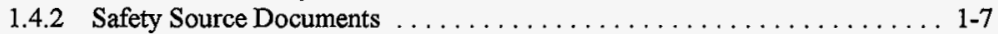

1.4 .3 Environmental Compliance Source Documents $\ldots \ldots \ldots \ldots \ldots \ldots \ldots$ 1-10

1.4.4 Quality Assurance Source Documents . . . . . . . . . . . . . 1-10

1.5 REFERENCES . . . . . . . . . . . . . . . . . . . . . . . 1-13

2.0 PROCESS AND FACILITY FUNCTIONAL REQUIREMENTS $\ldots \ldots \ldots \ldots \ldots \ldots$.

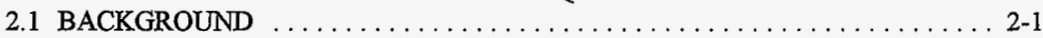

2.2 PROCESS AND FACILITY FUNCTIONAL REQUIREMENTS . . . . . . . . 2-8

2.2 .1 Facility Processing Mission Goals . . . . . . . . . . . . . . . . . 2-8

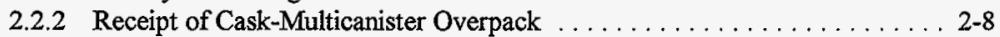

2.2.3 Cold Vacuum Drying Process Requirements . . . . . . . . . . . . . 2-9

2.2.4 Tempered Water System Requirements . . . . . . . . . . . . . . . . . . 2-10

2.2.5 Process Water Conditioning Requirements . . . . . . . . . . . . 2-11

2.2.6 Process Controls Requirements . . . . . . . . . . . . . . . . . 2-11

2.2.7 Cask-Multicanister Overpack Release from Cold Vacuum Drying

Facility ............................. 2-11

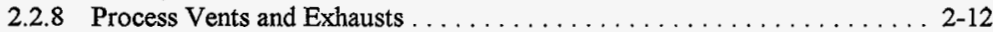

2.2.9 Cold Vacuum Drying Facility Requirements . . . . . . . . . . 2-12

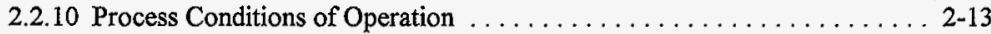

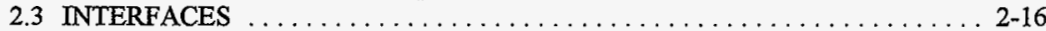

2.3.1 Multicanister Overpack Interfaces . . . . . . . . . . . . . 2-17

2.3.2 Multicanister Overpack Cask and Transporter Interfaces . . . . . . . . . 2-22

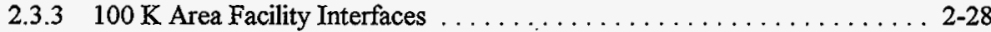

2.4 REFERENCES . . . . . . . . . . . . . . . . . . . . . . . . . . . . . . . 2-29

3.0 SAFETY FUNCTIONAL REQUIREMENTS $\ldots \ldots \ldots \ldots \ldots \ldots \ldots \ldots \ldots \ldots$. . . . . . .

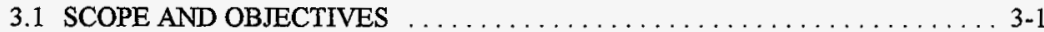

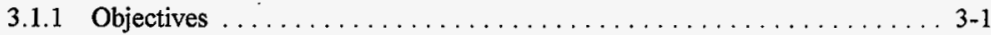

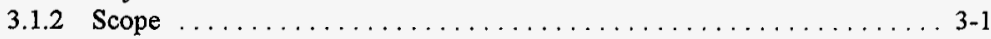

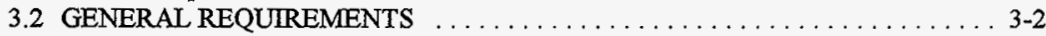

3.2 .1 Facility Hazards . . . . . . . . . . . . . . . . . . . . . . 3-2

3.2.2 Application of U.S. Department of Energy Orders and Statutes to Hazards . 3-3

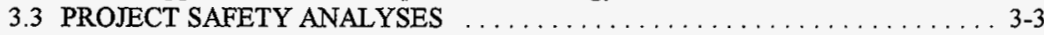

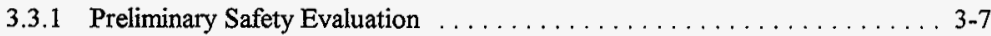

3.3.2 Shielding and Radiation Exposure Analysis $\ldots \ldots \ldots \ldots \ldots \ldots \ldots \ldots . . \ldots$

3.3 .3 Criticality Safety Evaluation Report . . . . . . . . . . . . . . 3-9 


\section{CONTENTS (Continued)}

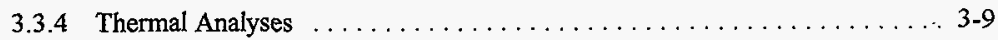

3.3.5 Nuclear Safety Hazards and Operability Study . . . . . . . . . . . . . 3-9

3.3.6 Multicanister Overpack Hydrogen Explosion . . . . . . . . . . . . . . . . 3-11

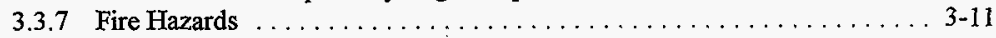

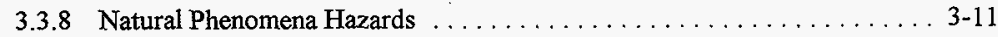

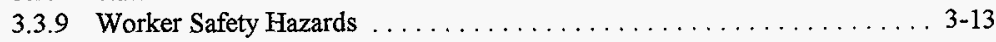

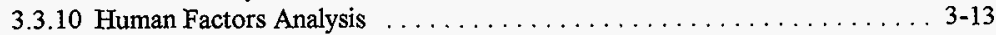

3.4 SAFETY FUNCTIONS AND DESIGN FEATURES $\ldots \ldots \ldots \ldots \ldots \ldots \ldots, 3-14$

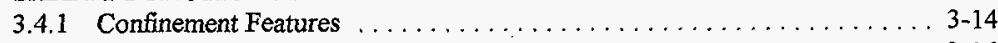

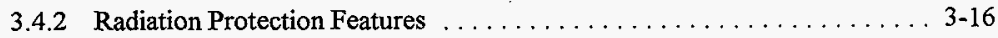

3.4.3 Criticality Prevention Features $\ldots \ldots \ldots \ldots \ldots \ldots \ldots \ldots \ldots \ldots \ldots \ldots . .17$

3.4.4 Multicanister Overpack Thermal Reaction Prevention Features ........ 3-18

3.4.5 Multicanister Overpack Hydrogen Deflagration/Detonation Prevention

Features $\ldots \ldots \ldots \ldots \ldots \ldots \ldots \ldots \ldots \ldots \ldots \ldots \ldots \ldots \ldots \ldots \ldots, 3-18$

3.4.6 Fire Protection Features . . . . . . . . . . . . . . . . . . . . 3-18

3.4.7 Natural Phenomena Hazard Mitigation Features . . . . . . . . . . . 3-18

3.4.8 Worker Safety Hazards Protection Features .................. 3-19

3.5 SAFETY BASIS SUMMARY AND REQUIREMENTS $\ldots \ldots \ldots \ldots \ldots \ldots .3-20$

3.5.1 Facility and Process Safe Shutdown $\ldots \ldots \ldots \ldots \ldots \ldots \ldots \ldots \ldots, 21$

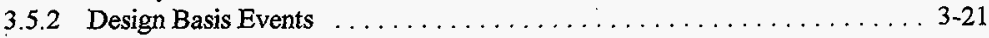

3.5.3 Environmental Qualification ......................... 3-24

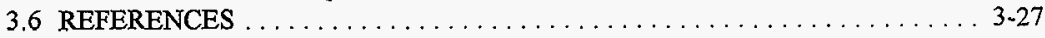

4.0 QUALITY ASSURANCE REQUIREMENTS $\ldots \ldots \ldots \ldots \ldots \ldots \ldots \ldots \ldots \ldots$ 4-1

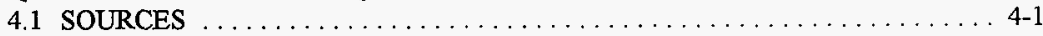

4.2 QUALITY ASSURANCE PROGRAM ................... 4 .1

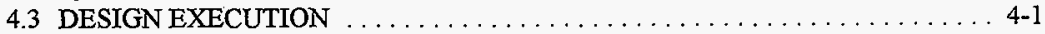

4.4 GRADED APPROACH $\ldots \ldots \ldots \ldots \ldots \ldots \ldots \ldots \ldots \ldots \ldots \ldots \ldots \ldots \ldots \ldots, 3$

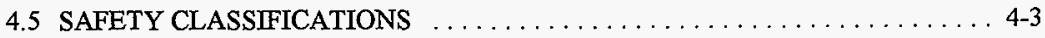

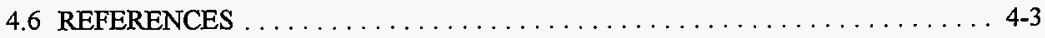

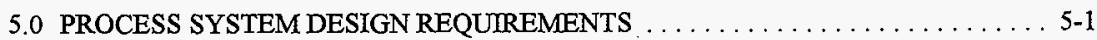

5.1 PROCESS GENERAL REQUIREMENTS $\ldots \ldots \ldots \ldots \ldots \ldots \ldots \ldots \ldots$. $5-1$

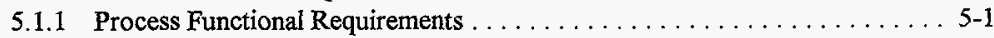

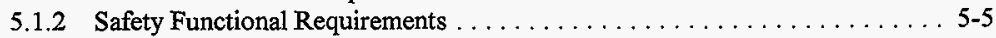

5.1.3 Testing, Surveillance and Maintenance Requirements . . . . . . . . 5-6

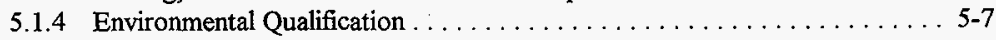

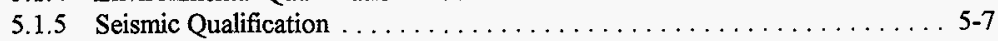

5.1 .6 Human Factors $\ldots \ldots \ldots \ldots \ldots \ldots \ldots \ldots \ldots \ldots \ldots \ldots . \ldots \ldots$ 


\section{CONTENTS (Continued)}

5.2 VACUUM AND PURGING SYSTEM DESIGN REQUIREMENTS . . . . . . . 5-9

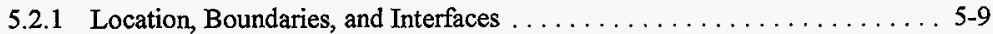

5.2 .2 Process Functional Requirements . . . . . . . . . . . . . . 5-10

5.2 .3 Safety Functional Requirements . . . . . . . . . . . . . . . . 5 5-10

5.2 .4 Process Performance Requirements $\ldots \ldots \ldots \ldots \ldots \ldots \ldots \ldots \ldots \ldots$ 5-11

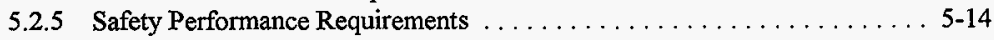

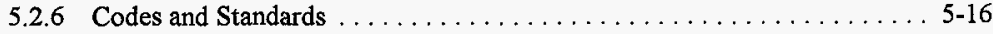

5.3 TEMPERED WATER SYSTEM DESIGN REQUIREMENTS $\ldots \ldots \ldots \ldots \ldots$. . 5-17

5.3 .1 Location, Boundaries, and Interfaces . . . . . . . . . . . . . . 5-17

5.3 .2 Process Functional Requirements . . . . . . . . . . . . . . 5-17

5.3 .3 Safety Functional Requirements . . . . . . . . . . . . . . . 5 $5-17$

5.3 .4 Process Performance Requirements $\ldots \ldots \ldots \ldots \ldots \ldots \ldots \ldots \ldots$. $\ldots \ldots$.18

5.3 .5 Safety Performance Requirements $\ldots \ldots \ldots \ldots \ldots \ldots \ldots \ldots \ldots . \ldots \ldots$

5.3 .6 Codes and Standards . . . . . . . . . . . . . . . . . 5-20

5.4 PROCESS WATER CONDITIONING SYSTEM DESIGN

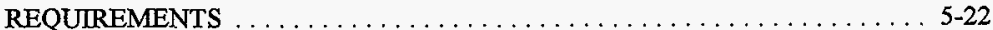

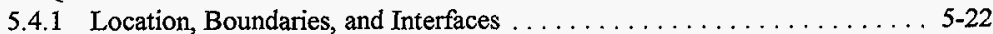

5.4 .2 Process Functional Requirements . . . . . . . . . . . . . . . 5-22

5.4 .3 Safety Functional Requirements . . . . . . . . . . . . . . . 5-22

5.4 .4 Process Performance Requirements . . . . . . . . . . . . . 5-23

5.4 .5 Safety Performance Requirements $\ldots \ldots \ldots \ldots \ldots \ldots \ldots \ldots \ldots \ldots$. $\ldots \ldots$

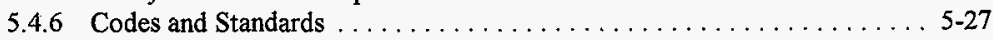

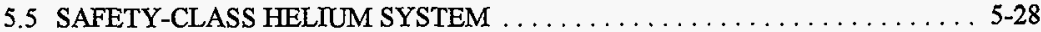

5.5 .1 Location, Boundaries, and Interfaces . . . . . . . . . . . . . . 5-28

5.5 .2 Process Functional Requirements . . . . . . . . . . . . . . . 5-28

5.5 .3 Safety Functional Requirements . . . . . . . . . . . . . . . 5-28

5.5 .4 Process Performance Requirements . . . . . . . . . . . . . . . . . . 5-29

5.5.5 Safety Performance Requirements . . . . . . . . . . . . . . . . . . 5-29

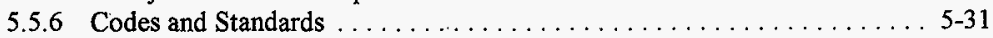

5.6 SAFETY-CLASS INSTRUMENTATION AND CONTROL SYSTEM . . . . . 5-31

5.6 .1 Location, Boundaries, and Interfaces . . . . . . . . . . . . . . . 5-31

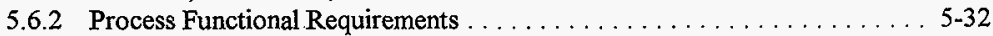

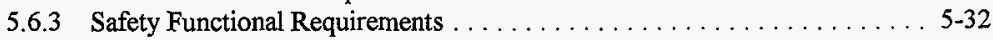

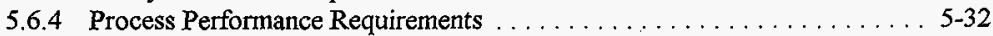

5.6.5 Safety Performance Requirements $\ldots \ldots \ldots \ldots \ldots \ldots \ldots \ldots \ldots \ldots \ldots \ldots$

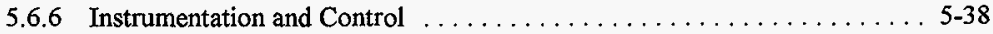

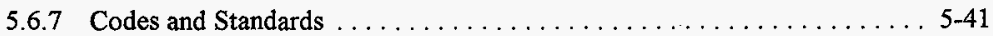

5.7 REFERENCES . . . . . . . . . . . . . . . . . . . . $5-41$ 


\section{HNF-SD-SNF-DRD-002 REV 1}

\section{CONTENTS (Continued)}

6.0 FACLITY DESIGN REQUIREMENTS $\ldots \ldots \ldots \ldots \ldots \ldots \ldots \ldots \ldots \ldots \ldots$ 6-1

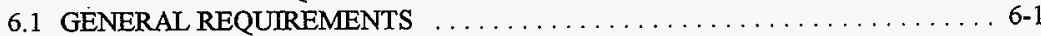

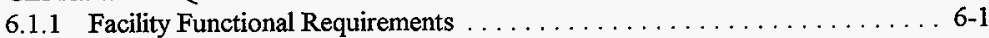

6.1 .2 Safety Functional Requirements . . . . . . . . . . . . . . . . .

6.1.3 Testing, Surveillance and Maintenance Requirements ........... 6-5

6.1 .4 Environmental Qualification ........................6.6 6

6.1 .5 Seismic Qualification . . . . . . . . . . . . . . . . . . . . . . $6-8$

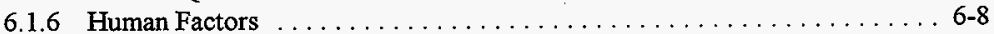

6.2 CIVIL DESIGN REQURREMENTS . . . . . . . . . . . . . . . . . . . 6-9

6.2 .1 Location, Boundaries, and Interfaces . . . . . . . . . . . . . . 6-9

6.2 .2 Facility Functional Requirements . . . . . . . . . . . . . . . . . . . 6-9

6.2.3 Safety Functional Requirements . . . . . . . . . . . . . . . . . 6-10

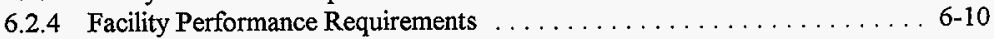

6.2.5 Safety Performance Requirements . . . . . . . . . . . . . . . . 6-11

6.2 .6 Codes and Standards . . . . . . . . . . . . . . . . . . . . . 6-11

6.3 STRUCTURAL DESIGN REQUIREMENTS $\ldots \ldots \ldots \ldots \ldots \ldots \ldots \ldots .6 .12$

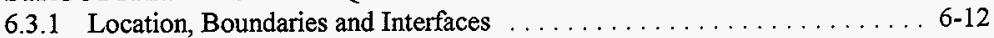

6.3.2 Facility Functional Requirements . . . . . . . . . . . . . . . . . 6-12

6.3.3 Safety Functional Requirements . . . . . . . . . . . . . . . . . 6-12

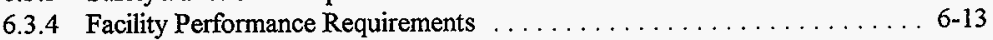

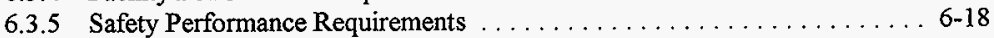

6.3 .6 Codes and Standards . . . . . . . . . . . . . . . . . . . . . . . 6-26

6.4 ARCHITECTURAL DESIGN REQUIREMENTS $\ldots \ldots \ldots \ldots \ldots \ldots \ldots .6 .26$

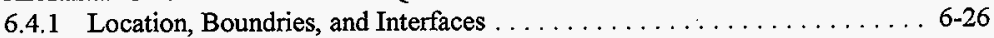

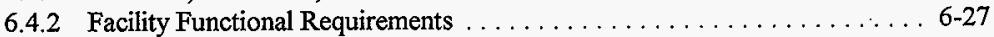

6.4 .3 Safety Functional Requirements . . . . . . . . . . . . . . . . . . . 6-28

6.4 .4 Facility Performance Requiirements . . . . . . . . . . . . . . . . 6-28

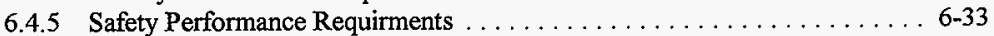

6.4 .6 Codes and Standards .......................... 6-33

6.5 HEATING, VENTILATING, AND AIR CONDITIONING DESIGN CONSIDERATIONS AND STANDARD PRACTICES $\ldots \ldots \ldots \ldots \ldots \ldots \ldots 6-34$

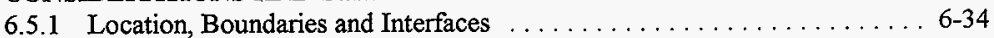

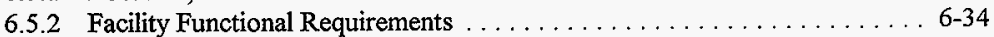

6.5 .3 Safety Functional Requirements . . . . . . . . . . . . . . . . 6-37

6.5.4 Functional Performance Requirements . . . . . . . . . . . . . 6-38

6.5.5 Safety Performance Requirements . . . . . . . . . . . . . . . . . 6-44

6.5 .6 Codes and Standards . . . . . . . . . . . . . . . . . . . . . . . . . . . 6 6-44

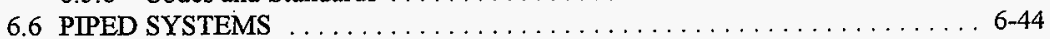

6.6.1 Location, Boundaries, and Interfaces. . . . . . . . . . . . . . 6-44

6.6 .2 Facility Functional Requirements . . . . . . . . . . . . . . . . . 6-45

6.6 .3 Safety Functional Requirements . . . . . . . . . . . . . . . 6-47

6.6 .4 Functional Performance Requirements . . . . . . . . . . . . . 6-47 


\section{CONTENTS (Continued)}

6.6.5 Safety Performance Requirements . . . . . . . . . . . . . . . . 6-52

6.6 .6 Codes and Standards Documents . . . . . . . . . . . . . . . . . 6-52

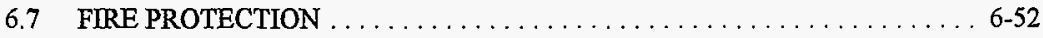

6.7.1 Location, Boundaries, and Interfaces . . . . . . . . . . . . 6-53

6.7 .2 Facility Functional Requirements $\ldots \ldots \ldots \ldots \ldots \ldots \ldots \ldots \ldots, 6 \ldots \ldots$

6.7 .3 Safety Functional Requirements . . . . . . . . . . . . . . . . 6-54

6.7 .4 Functional Performance Requirements . . . . . . . . . . . . 6-55

6.7 .5 Safety Functional Requirements . . . . . . . . . . . . . . . . . . . 6-59

6.7 .6 Codes, Standards, and Source Documents . . . . . . . . . . . . 6-59

6.8 RADIOACTIVE EFFLUENT HANDLING AND DISPOSAL . . . . . . . 6-59

6.8 .1 Locations, Boundaries, and Interfaces . . . . . . . . . . . . . 6-59

6.8 .2 Facility Functional Requirements $\ldots \ldots \ldots \ldots \ldots \ldots \ldots \ldots \ldots 6.59$

6.8.3 Safety Functional Requirements . . . . . . . . . . . . . . . . . . . . 6-60

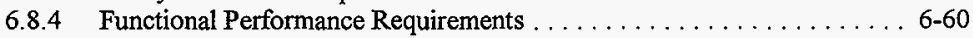

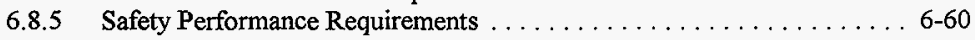

6.8 .6 Codes and Standards ........................... 6-60

6.9 SPECIALTY EQUIPMENT AND TOOLS REQUTREMENTS . . . . . . . 6-61

6.9.1 Locations, Boundaries, and Int 6 - 639 .2Facility Functional Requirements6-61

6.9 .3 Safety Functional Requirements . . . . . . . . . . . . . . . . . 6-623

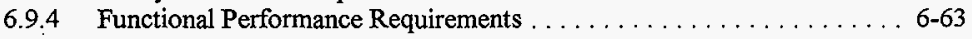

6.9.5 Safety Performance Requirements . . . . . . . . . . . . . . 6-65

6.10 SECURITY SYSTEM REQUIREMENTS $\ldots \ldots \ldots \ldots \ldots \ldots \ldots \ldots .6 .65$

6.10 .1 Location, Boundaries and Interfaces . . . . . . . . . . . . 6-65

6.10.2 Cold Vacuum Drying Facility Security System Functional

Requirements ........................6.65

6.10 .3 Safety Functional Requirements . . . . . . . . . . . . . . . . 6-68

6.10 .4 Functional Performance Requirements . . . . . . . . . . . . . . . 6-68

6.10 .5 Safety Performance Requirements . . . . . . . . . . . . . . . . . . 6-71

6.10 .6 Codes, Standards, and Source Documents . . . . . . . . . . . . 6-71

6.11 COMMUNICATIONS SYSTEM REQUIREMENTS $\ldots \ldots \ldots \ldots \ldots \ldots, 6-72$

6.11 .1 Location, Boundaries and Interfaces $\ldots \ldots \ldots \ldots \ldots \ldots \ldots \ldots, 6-72$

6.11 .2 System Functional Requirements . . . . . . . . . . . . . . . . . . 6-72

6.11 .3 Safety Functional Requirements . . . . . . . . . . . . . . . 6-73

6.11.4 Communications Performance Requirements ............ 6-73

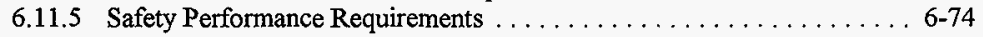

6.11 .6 Codes, Standards, and Source Documents . . . . . . . . . . . . . 6-75

6.12 RADIATION MONITORING SYSTEM . . . . . . . . . . . . . . . . . 6-76

6.12 .1 Location, Boundaries, and Interfaces . . . . . . . . . . . . 6-76

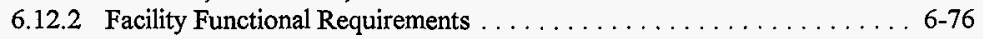

6.12 .3 Safety Functional Requirements . . . . . . . . . . . . . . . . . . . 6-77

6.12 .4 Functional Performance Requirements . . . . . . . . . . . . . . 6-77

6.12.5 Safety Performance Requirements . . . . . . . . . . . . . . . . . . . 6-83

6.12 .6 Codes, Standards, and Source Documents . . . . . . . . . . . . 6-83 


\section{CONTENTS (Continued)}

6.13 MONITORING AND CONTROL SYSTEM-FACILITY . . . . . . . . 6-83

6.13 .1 Location, Boundaries and Interfaces $\ldots \ldots \ldots \ldots \ldots \ldots \ldots \ldots . \ldots 63$

6.13 .2 Facility Functional Requirements . . . . . . . . . . . . . . 6-84

6.13 .3 Safety Functional Requirements . . . . . . . . . . . . . . 6-85

6.13 .4 Functional Performance Requirements . . . . . . . . . . . . 6 6-85

6.13 .5 Safety Performance Requirements . . . . . . . . . . . . . 6-88

6.13 .6 Codes and Standards . . . . . . . . . . . . . . . . . . 6.88

6.14 ELECTRICAL POWER DISTRIBUTION AND LIGHTING SYSTEM . . . . $6-89$

6.14 .1 Location, Boundaries and Interfaces . . . . . . . . . . . . . 6-89

6.14 .2 Facility Functional Requirements . . . . . . . . . . . . . . . 6-90

6.14 .3 Safety Functional Requirements . . . . . . . . . . . . . . . . . 6-90

6.14 .4 Functional Performance Requirements . . . . . . . . . . . . . . . . . . . 6-90

6.14.5 Safety Performance Requirements . . . . . . . . . . . . . 6-104

6.14 .6 Codes and Standards . . . . . . . . . . . . . . . . . . 6-104

6.15 REFERENCES .......................... 6-104

7.0 DESIGN AND OPERATIONAL READINESS DOCUMENTATION $\ldots \ldots \ldots \ldots \ldots$. . .

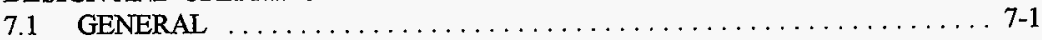

7.2 AS-LOW-AS-REASONABLY-ACHIEVABLE REQUIREMENTS $\ldots \ldots \ldots$. .

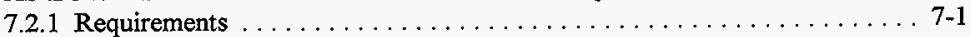

7.2.2 As-Low-As-Reasonably-Achievable Analysis Documentation . . . . . . . . 7-1

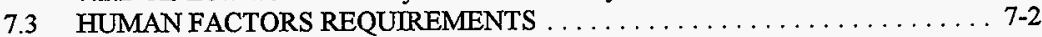

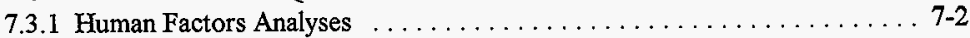

7.4 OPERATIONS AND MAINTENANCE REQUIREMENTS $\ldots \ldots \ldots \ldots \ldots . .74$

7.4.1 Operating and Maintenance Manual Requirements . . . . . . . . . . 7-4

7.4 .2 Waste Management Plan . . . . . . . . . . . . . . . . . 7-5

7.4.3 Occupational Safety and Health Administration Requirements

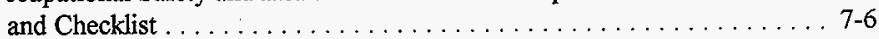

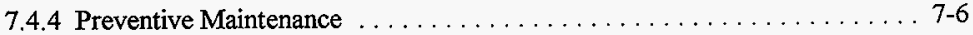

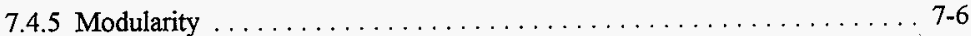

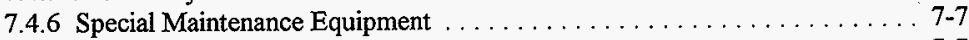

7.4 .7 Calibration and Testing . . . . . . . . . . . . . . . . . . . . . $7-7$

7.4 .8 Components and Spare Parts List $\ldots \ldots \ldots \ldots \ldots \ldots \ldots \ldots \ldots \ldots \ldots$

7.5 TEST REQUTREMENTS $\ldots \ldots \ldots \ldots \ldots \ldots \ldots \ldots \ldots \ldots \ldots \ldots \ldots \ldots$

7.5.1 Test and Inspection Requirements Plans . . . . . . . . . . . . . 7-8

7.5.2 Integrated Systems Test Plans $\ldots \ldots \ldots \ldots \ldots \ldots \ldots \ldots \ldots \ldots \ldots . \ldots \ldots$

7.5.3 Spent Nuclear Fuel Project Process Validation Requirements . . . . . . . . 7-9

7.6 EQUIPMENT TURNOVER $\ldots \ldots \ldots \ldots \ldots \ldots \ldots \ldots \ldots \ldots \ldots \ldots$

7.6.1 Equipment Packages . . . . . . . . . . . . . . . . . . . . . 7-9

7.7 DECONTAMINATION AND DECOMMISSIONING . . . . . . . . . . 7-10

7.7.1 Decontamination and Decommissioning Compliance Plans . . . . . . . 7-10

7.8 REFERENCES $\ldots \ldots \ldots \ldots \ldots \ldots \ldots \ldots \ldots \ldots \ldots \ldots \ldots \ldots \ldots$ 


\section{CONTENTS (Continued)}

\section{APPENDIXES}

A REQUIREMENTS FROM THE CODE OF FEDERAL REGULATIONS AND U.S. DEPARTMENT OF ENERGY ORDERS . . . . . . . . . . . . . . A-1

B U.S. NUCLEAR REGULATORY COMMISSION EQUTVALENCY

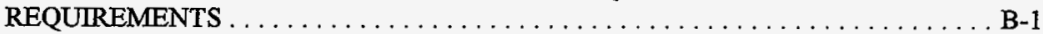

C DEFINITION OF LOW SPECIFIC ACTIVITY MATERIAL $\ldots \ldots \ldots \ldots \ldots \ldots$ C-1

D PROCESS CONDITIONS OF OPERATION $\ldots \ldots \ldots \ldots \ldots \ldots \ldots \ldots \ldots \ldots$ D-1

E SAMPLE STRUCTURES AND EQUIPMENT LIST FOR THE COLD VACUUM DRYING FACILITY . . . . . . . . . . . . . . . . . . . E-1 
HNF-SD-SNF-DRD-002 REV 1

\section{LIST OF FIGURES}

2-1 Cold Vacuum Drying Facility Relationship to Other Spent Nuclear Fuel

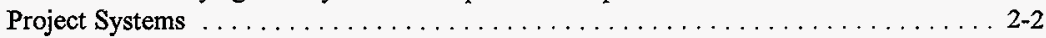

2-2 Generalized Description of Water Removal from a Multicanister Overpack . . . . . . 2-4

2-3 Water Removed by Fuel Drying (Masses Based on a Nominal Mark IV

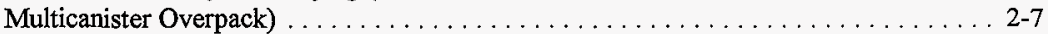

2-4 Cask-Multicanister Overpack Configuration upon Receipt at the Cold Vacuum

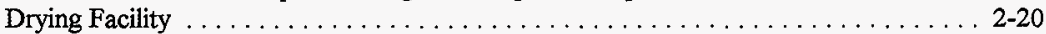

5-1 Example of Cold Vacuum Drying Facility Safety Class Logic Panel Train A . . . . . . 5-34

5-2 Example of Safety Class Relay Logic Schematic . . . . . . . . . . . . . . 5-35 


\section{LIST OF TABLES}

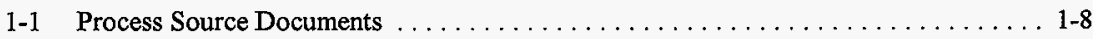

1-2 Cold Vacuum Drying Facility Safety Requirements Sources . . . . . . . . . . . . 1-9

1-3 Environmental Compliance Source Documents $\ldots \ldots \ldots \ldots \ldots \ldots \ldots \ldots \ldots \ldots$

1-4 Quality Assurance Source Documents . . . . . . . . . . . . . . . . 1-12

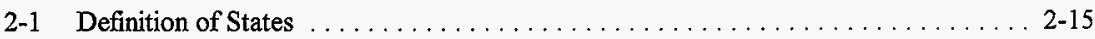

2-2 Multicanister Overpack Configuration and Content Description ........... 2-18

2-3 Concentration of Radionuclides in Water Contained by a Multicanister Overpack . . 2-21

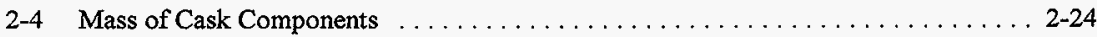

2-5 Multicanister Overpack Cask and Multicanister Overpack Weights $\ldots \ldots \ldots \ldots \ldots$ 2-25

2-6 Dose Rates for a Wet Multicanister Overpack with Cask Lid Removed . . . . . . . 2-26

2-7 Dose Rates for a Dry Multicanister Overpack with Cask Lid in Place . . . . . . . . 2-26

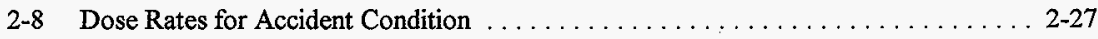

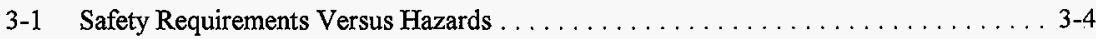

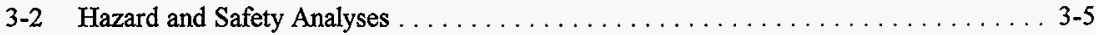

3-3 Safety Analyses Design Bases and Requirements $\ldots \ldots \ldots \ldots \ldots \ldots \ldots \ldots \ldots \ldots \ldots$

3-4 Preliminary List of Safety-Class and Safety-Significant Functions Required by

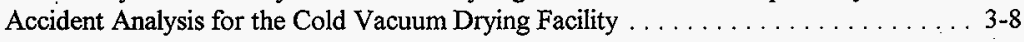

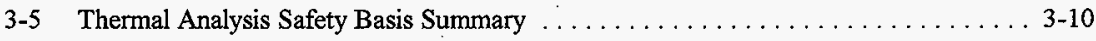

3-6 Cold Vacuum Drying System Safety-Class Performance Category 3 Natural Phenomena Design Loads $\ldots \ldots \ldots \ldots \ldots \ldots \ldots \ldots \ldots \ldots \ldots \ldots \ldots \ldots \ldots \ldots \ldots, 12$

3-7 Hazards, Safety Functions, Design Basis Accidents, Safety Classifications and

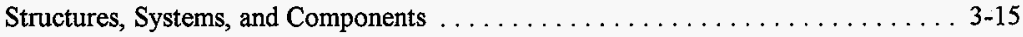

3-8 Structure, System, and Component Safety Design Requirements $\ldots \ldots \ldots \ldots \ldots$ 3-22 


\section{LIST OF TABLES (Continued)}

3-9 Matrix of Design Basis Event Conditions to be Incorporated into Design . . . . . . . . 3-25

3-10 Environmental Qualification Requirements for General Services, Safety-Significant and Safety-Class Structures, Systems, and Components . . . . . . . . . . 3-26

4-1 Cold Vacuum Drying Facility Quality Assurance Requirements Sources $\ldots \ldots \ldots$ 4-2

5-1 Process and Safety Functional Requirements $\ldots \ldots \ldots \ldots \ldots \ldots \ldots \ldots . \ldots \ldots$. $\ldots \ldots \ldots$

5-2 Required Codes and Standards for the Cold Vacuum Drying Facility Process System Structures, Systems, and Components. . . . . . . . . . . . . . . . 5-3

5-3 Environmental Qualification Requirements for General Services, Safety-Significant and Safety-Class Structures, Systems, and Components . . . . . . . . . . . . . 5-8

5-4 Vacuum Purge System Design Requirements . . . . . . . . . . . . . . . . . 5-16

5-5 Tempered Water System Design Requirements $\ldots \ldots \ldots \ldots \ldots \ldots \ldots \ldots . . \ldots \ldots \ldots$

5-6 Process Water Conditioning System Design Requirements . . . . . . . . . . . . . 5 5-27

5-7 Safety Class Helium System Design Requirements ............... 5-31

5-8 Safety Class Instrumentation and Control System Design Requirements . . . . . . . . 5 5-41

$6-1$ Facility and Safety Functional Requirements $\ldots \ldots \ldots \ldots \ldots \ldots \ldots \ldots \ldots \ldots \ldots$

6-2 Required Codes and Standards for the Cold Vacuum Drying Facility Process System Structures, Systems, and Components . . . . . . . . . . . . . . 6-3

6-3 Environmental Qualification Requirements for General Services, Safety-Significant and Safety-Class Structures, Systems, and Components . . . . . . . . . . . . 6-7

6-4 Heating, Ventilating, and Air Conditioning System Design Requirements . . . . . . . 6-37

6-5 Facility Systems Interfaces for the Cold Vacuum Drying Facility $\ldots \ldots \ldots \ldots \ldots 6-46$

6-6 Structure, System, and Component Structural Performance Categories . . . . . . 6-52

6-7 Codes, Standards, and Source Documents that Apply to Cold Vacuum Drying

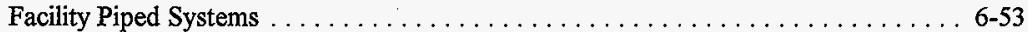




\section{LIST OF TABLES (Continued)}

6-8 Codes, Standards, and Source Documents Applicable to the Design of Fire Protection Systems in the Cold Vacuum Drying Facility .

6-9 Cold Vacuum Drying Facility Security System Design Requirements

6-10 Codes, Standards, and Source Documents Applicable to the Design of the Cold Vacuum Drying Facility Security System

6-11 Cold Vacuum Drying Facility Communication System Design Requirements

6-12 Codes, Standards, and Source Documents Applicable to the Design of the Cold Vacuum Drying Facility Communications System

6-13 Monitoring and Control System Design Requirements $\ldots \ldots \ldots \ldots \ldots \ldots .68$

6-14 Codes and Standards Applicable to the Design of the Cold Vacuum Drying Monitoring and Control System

6-15 Minimum Distance Separating Transformers from Buildings.

6-16 Demand Factors.

6-17 Electrical Enclosures.

6-18 Motor Ratings $6-98$

6-19 Electrical Power System Design Requirements

7-1 Codes and Standards Applicable to Human Factors Engineering on the Cold Vacuum Drying Facility 
HNF-SD-SNF-DRD-002 REV 1

\section{LIST OF TERMS}

$\begin{array}{ll}\text { ACGIH } & \text { American Conference of Governmental Industrial Hygienists } \\ \text { ALARA } & \text { as low as reasonably achievable } \\ \text { ASHRAE } & \text { American Society of Heating, Refrigeration, and Air Conditioning Engineers } \\ \text { CSB } & \text { Canister Storage Building } \\ \text { CVDF } & \text { Cold Vacuum Drying Facility } \\ \text { DBA } & \text { design basis accident } \\ \text { DBE } & \text { design basis earthquake } \\ \text { DOE } & \text { U.S. Department of Energy } \\ \text { DRD } & \text { Design Requirements Document } \\ \text { HEPA } & \text { high-efficiency particulate air (filter) } \\ \text { HVAC } & \text { heating, ventilating, and air conditioning } \\ \text { I\&C } & \text { instrumentation and control } \\ \text { IEEE } & \text { Institute of Electrical and Electronics Engineers, Inc. } \\ \text { ISRS } & \text { in-structure response spectra } \\ \text { IWTS } & \text { Integrated Water Treatment System } \\ \text { IXM } & \text { ion exchange module } \\ \text { MCO } & \text { multicanister overpack } \\ \text { MCS } & \text { monitor and control system } \\ \text { NA } & \text { not applicable } \\ \text { NC } & \text { normal conditions } \\ \text { NEC } & \text { National Electrical Code } \\ \text { NFPA } & \text { National Fire Protection Association } \\ \text { NPH } & \text { natural phenomena hazard } \\ \text { NRC } & \text { U.S. Nuclear Regulatory Commission } \\ \text { PC } & \text { performance category } \\ \text { PWC } & \text { process water conditioning } \\ \text { RL } & \text { U.S. Department of Energy, Richland Operations Office } \\ \text { SC } & \text { safety class } \\ \text { SCHe } & \text { safety class helium } \\ \text { SCI\&C } & \text { safety class instrumentation and control } \\ \text { SNF } & \text { spent nuclear fuel } \\ \text { SS } & \text { safety significant } \\ \text { SSC } & \text { structure, system, and component } \\ \text { SSI } & \text { soil structure interaction } \\ \text { TBD } & \text { to be determined } \\ \text { TRU } & \text { transuranic } \\ \text { TWS } & \text { tempered water system } \\ \text { UBC } & \text { Uniform Building Code } \\ \text { UL } & \text { Underwriters Laboratories } \\ \text { UPS } & \text { uninterruptible powrer supply } \\ \text { VPS } & \text { vacuum purge system } \\ & \\ & \end{array}$




\section{HNF-SD-SNF-DRD-002 REV 1}

\subsection{GENERAL}

\subsection{MISSION OBJECTIVE}

The objectives of the U.S. Department of Energy (DOE) at the Hanford Site include cleaning up the Site, protecting the health and safety of workers and the public, and protecting the environment. The cleanup will be accomplished in accordance with the Hanford Federal Facility Agreement and Consent Order (Tri-Party Agreement) and in compliance with applicable federal, state, local laws, and American Indian treaty rights. The Hanford Site cleanup must also comply with DOE policies and directives.

Approximately 2,100 metric tons (2,300 tons) of spent nuclear fuel (SNF) are stored in the $\mathrm{K}$ Basins at the Hanford Site. Much of this fuel has been broken as a result of handling, resulting in corrosion of the SNF and contamination of the basin water. A project is underway to remove the SNF from the basins and place it in stable dry storage, because the basins, which are approximately 40 years old, have leaked.

In November 1994, the DOE approved the SNF Project "Path Forward" recommendation (Lytle 1994) to resolve the safety and environmental concerns associated with the deteriorating SNF stored in the K Basins at the Hanford Site. The Path Forward recommendation (Bergman 1994) involved a series of projects to safely retrieve, package, transport, condition, and store K Basins fuels and sludge.

The scope of the SNF Project includes retrieval of all SNF at the K Basins for packaging and transportation to interim storage (WHC-SD-SNF-SD-005). The configuration of systems selected for $\mathrm{K}$ Basin fuel retrieval and storage was based on evaluations of alternative strategies that resulted in defining a group of systems for placing the fuel in dry storage (WHC-SD-SNF-SD-005). A two-step drying process was selected from the alternatives evaluated to expedite the schedule for removal of fuel from the $\mathrm{K}$ Basins.

The SNF project is responsible for the following activities.

- Remove the SNF from the K Basins.

The SNF will be repackaged so that it is contained in baskets stacked within an overpack vessel called the multicanister overpack (MCO). The MCO, which will be loaded in the basin below the water so that it contains SNF and contaminated water, will be placed in a shield cask on a transport trailer for removal from the basin building.

- Drain and dry the SNF and MCO.

The transport trailer with the cask and MCO will be pulled from the basin building to a nearby facility, called the Cold Vacuum Drying Facility (CVDF), at the K Basin site 
where the water will be drained from the $\mathrm{MCO}$ and the first drying process will be performed. This step will dry the SNF and fill the MCO with an inert gas, thus reducing the corrosion rate and stabilizing the fuel so that it can be temporarily stored safely while awaiting a final treatment step leading to long term storage. The product of this step is a dried SNF in a inert gas pressurized (slightly above atmospheric) MCO.

- Move the SNF to the Canister Storage Building (CSB).

The dried and inert gas-filled $\mathrm{MCO}$, which will remain in the cask on the transporter, will be towed to a location on the Hanford Site that is approximately $16 \mathrm{~km}$ (10 $\mathrm{mi})$ distant.

- Hot condition the SNF for placement into storage.

The SNF will be dehydrated at high temperature and dehydrided to prepare for 40-year storage in sealed MCOs. The hot conditioning will be accomplished using equipment installed in an annex of the CSB.

- Store the SNF.

The dry, stabilized, SNF contained in the MCOs will be placed into storage in the CSB.

- Process K Basin sludge.

The sludge from the basin floor, consisting of accumulated dirt and corrosion products, will be vacuumed from the pool, separated, dewatered and converted into a storable or disposable form.

- Decommission the $\mathrm{K}$ Basins.

Debris will be removed, basin water will be processed, and the basins will be decontaminated and decommissioned.

The process flow diagrams for the SNF and CVDF are shown on drawings H-2-825868 and H- $1-81166$ respectively.

A number of related projects have been established in order to provide equipment and facilities to accomplish the removal and long term storage of the SNF:

- Fuel retrieval facilities and equipment

Equipment for handling the cask and $\mathrm{MCO}$, for handling fuel, and for cleaning fuel will be designed and constructed. $\mathrm{K}$ Basins facility modifications will be made. 
- Water treatment

A new water treatment system will be provided for the basin water to handle the increased load during removal operations.

- CVDF

A new nonreactor, nuclear facility (hazard category 2, performance category [PC] 2 and 3) with drying equipment will be designed and constructed.

- $\mathrm{MCO}$

An MCO design will be completed and approximately 430 will be purchased.

- Cask-transporter system

Casks and transport trailers will be built.

- $\mathrm{CSB}$

A building and equipment will be designed and constructed for the storage of the SNF. The CSB will contain an annex for hot conditioning the SNF.

- Hot Conditioning System equipment

The hot conditioning process equipment will be provided.

- MCO handling machine

The machine for transporting the MCO within the CSB and for effecting input and output operations with the storage tubes will be designed and constructed.

- Sludge treatment process

Process equipment will be provided to treat the sludge. The sludge treatment process will be conducted at the CVDF following the removal of all fuel from the $\mathrm{K}$ Basins. Sludge processing at the CVDF is outside the scope of this document.

As part of the Path Forward the CVDF Project was created to provide part one of a two-step fuel drying and conditioning process that achieves the earliest possible removal of free water from repackaged fuel and halts further fuel degradation. The purpose of the CVDF Project is to provide the processes and facilities required to drain and dry the water- and SNF-filled $\mathrm{MCO}$ after they have been removed from the $\mathrm{K}$ Basins. 
The CVDF will be a facility constructed at the $\mathrm{K}$ Basin site within a few hundred meters of the basins. The CVDF location was chosen based on a site selection evaluation that was done to determine the optimal site on which to build. The criteria used to determine the site were technical feasibility, schedule feasibility, operations, cost and regulatory requirements. This evaluation is documented in Letter 2002-PI-96-004 (Swenson 1996).

The CVDF will remove free water from the MCOs to reduce the potential for continued fuel-water corrosion reactions. The cold vacuum drying process involves the draining of bulk water from the $\mathrm{MCO}$ and subsequent vacuum drying at $50^{\circ} \mathrm{C}\left(122^{\circ} \mathrm{F}\right)$. The $\mathrm{MCO}$ will be evacuated to a pressure of $400 \mathrm{~Pa}$ ( 3 torr) or less and backfilled with an inert gas (helium). The MCO will be sealed and then transported with the cask to the CSB. The CVDF will have a minimum of four drying stations (with capability to expand to a fifth station), and will provide excess capacity to simplify transport operations as defined by WHC-SD-SNF-TI-016, Development of Design Basis Capacity for SNF Project Systems. The CVDF subproject acquires the required process systems, supporting equipment, and facilities. The cold vacuum drying operations deliver an MCO containing dried fuel to the cask-transporter system for shipment to the CSB. The CVDF subproject also provides equipment to dispose of solid wastes generated by the cold vacuum drying process and shall transport process water removed from the MCO back to the KW Basin.

\subsection{FACILITY CLASSIFICATION}

The CVDF is a "Nuclear Facility," as defined in DOE Order 6430.1A, General Design Criteria, "Glossary of Terms," and is designated a "Special Facility," as defined by Paragraph 1300-1.1. The criteria given in Division 13, "Special Facilities," are the basic guidance for the design of the facility. Application of Division 13 requirements involves the general requirements given in Section 1300 as well as the requirements given in the applicable facility type section. In addition, the special facilities-specific paragraphs labeled - 99.0 in "Discipline Divisions" apply.

The most appropriate facility type is "irradiated fissile material storage facility," which is governed by the requirements of Section 1320. In addition, the -99.14 paragraphs in "Discipline Requirements Divisions" apply as well.

Paragraph 1320-1 defines the criteria covered by this section. The key criteria are as follows.

- The material has been exposed to neutron fluence in a nuclear reactor (e.g., SNF and target elements).

- The irradiated material is properly clad or canned when received such that leakage from the assemblies is minimized. 
- The integrity of the canning must be ensured.

- The section applies to water pool-type or dry-type storage.

The existence of some contamination in the drying process system is considered to be a minor perturbation that does not significantly change the character of the facility from being a temporary storage facility.

\subsection{SCOPE OF THE DESIGN REQUIREMENTS DOCUMENT}

This Design Requirements Document (DRD) establishes the basic process, safety and quality assurance requirements, criteria, and data for the CVDF systems and facility. This DRD also establishes the operational readiness documentation required for testing, operation, maintenance, decontamination and decommissioning.

\subsection{PROJECT SOURCE DOCUMENTS}

The design of the CVDF will be governed by DOE Directives (orders) and standards, federal regulations, Washington State regulations, Hanford Site standards, and various industry standards and guidelines. In order to provide a design for the safe and efficient performance of this function, numerous regulations, policies, and directives must be used for guidance. WHC-SD-SNF-FRD-020, $K$ Basin Spent Nuclear Fuel Cold Vacuum Drying Facility Functions and Requirements, summarizes the requirements of the CVDF subproject and identifies federal, state, and local regulations and laws that may be applicable to the CVDF Subproject. HNF-S-0435, Performance Specification for the K-Basin Spent Nuclear Fuel Cold Vacuum Drying Facility, provides functional design and performance requirements for the K Basin SNF CVDF. These performance requirements provide the basis for the design, development, and testing of equipment to safely and efficiently vacuum dry the K Basin SNF.

The scope of this section is to demonstrate an understanding of the documents that are applicable to the CVDF subproject and that have an impact on the design, operation and maintenance of the CVDF. The documents can be roughly categorized as design basis guidance and reference material. The Functions and Requirements Document (WHC-SD-SNF-FRD-020) identifies a considerable number of documents that are passed down from the project-level functional hierarchy and, as such, may have an impact on the design of the CVDF Subproject. This review has determined that the bulk of the documents are applicable to the CVDF Subproject but do not have an impact on the design.

The Functions and Requirements Document (WHC-SD-SNF-FRD-020) outlines the CVDF functions and traces the relationship to the SNF Project through the work breakdown structure and organizational block diagrams. The technical requirements and descriptions are organized by work breakdown structure number and the associated requirement references are listed. The requirements listed include federal, state, and local laws and regulations as well as Hanford Site 
rules and regulations. The functions and requirements in WHC-SD-SNF-FRD-020 implement the requirements set forth in WHC-SD-SNF-PMP-01 1, Spent Nuclear Fuel Program Project, Project Management Plan, which requires management, development, and maintenance of baseline documentation. The requirements listed in WHC-SD-SNF-FRD-020 consist mainly of requirements from the Code of Federal Regulations, DOE orders, Washington Administrative Codes, the Revised Code of Washington, Hanford Site controlled manuals, and other miscellaneous documents.

The Code of Federal Regulations is a codification of applicable regulations promulgated by an issuing federal agency and published in the Federal Register. The Code is divided into 50 titles that represent broad areas subject to federal regulations. Each title is divided into chapters, which usually bear the name of the issuing agency. Each chapter is further subdivided into several parts to address specific regulations. Historically, the Code of Federal Regulations have applied to commercial nuclear reactor facilities but not to government-owned, contractor-operated sites such as the Hanford Site. The federal government desires to provide adequate protection of the public from radioactive material releases associated with normal operations and accidents and natural phenomena. To this end, the Congress has legislated that this is generally the responsibility of the DOE where DOE facilities are involved and generally the responsibility of the U.S. Nuclear Regulatory Commission (NRC) where commercial facilities are involved. The Congress has further established the Defense Nuclear Facilities Safety Board as an oversight agency for the DOE. 10 CFR 30.12, "Persons Using Byproduct Material Under Certain Department of Energy and Nuclear Regulatory Commission Contracts," indicates that prime contractors of the DOE are exempt from the regulations to the extent that the contractor working under his prime contract manufactures, produces, transfers, receives, acquires, owns, possesses, or uses byproduct material for the performance of work for the $\mathrm{DOE}$ at a government-owned, contractor-operated site. The wording very specifically says prime contractors because such contractors operate DOE-owned facilities on the DOE's behalf. This exemption applies to the CVDF. The DOE established in the K Basin Spent Nuclear Fuel Project - Regulatory Policy, dated August 4, 1995, the requirement for the SNF Project facilities to achieve "nuclear safety equivalency" comparable to that of NRC-licensed facilities. An evaluation was performed to identify any additional requirements that were needed to supplement the existing and applicable DOE requirements to establish nuclear safety equivalency with the NRC-licensed facilities. The additional requirements were consolidated into 29 items. All items are to be implemented in accordance with the NRC regulations with the exception of the design earthquake, which will be implemented in a manner that established equivalence in safety, as opposed to direct equivalence to the regulation.

The DOE orders establish policies, guidelines, and requirements for the safe operation and maintenance of DOE-owned facilities. Historically, these orders have been considered to be the governing regulations, not the Code of Federal Regulations, for the DOE government-owned, contractor-operated sites. In addition to DOE orders, several supplemental guidance documents, which are specific to the Hanford Site, are also listed in the Functions and Requirements Document (WHC-SD-SNF-FRD-020).

The Washington Administrative Code and the Revised Code of Washington are compiled by the various agencies of Washington State. Washington Administrative Codes and Revised Codes 
of Washington are normally considered to be additional requirements to federal guidelines rather than as replacements. However, Washington Administrative Codes promulgate similar requirements as the Code of Federal Regulations in many instances. Hence, compliance with either federal or state regulations is normally considered adequate. Since 10 CFR 30.12 exempts the CVDF from the Code of Federal Regulations, in this case it is the state regulations that apply. The Hanford site has created several controlled manuals. The purpose of these controlled manuals is to establish various compliance requirements and guidelines in conjunction with applicable DOE orders, and federal, state, and local laws and regulations.

DOE Order 6430.1A gives the main requirements needed for the design. The quality assurance requirements are given in 10 CFR Part 930.120, "Nuclear Safety Management."

\subsubsection{Process and Facility Source Documents}

The documents listed in Table 1-1 shall be used in the design of the CVDF structures, systems, and components (SSCs). Codes, standards, and DOE directives are always undergoing a process of revision and replacement. The CVDF Project shall be based on the versions that were in effect on January 1, 1996.

\subsubsection{Safety Source Documents}

The source documents for implementation of safety on the CVDF design are derived from DOE orders, federal and state statutes, and project-imposed NRC equivalency requirements. A Preliminary Safety Evaluation was performed (WHC-SD-SNF-PSE-003), which evaluated hazards to determine a safety basis for facility design. The regulatory requirements sources are listed in Table 1-2.

DOE Order 6430.1A, provides overall general safety design requirements applicable to all SSCs. The applicable sections of DOE Order 6430.1A for CVDF are listed in Appendix A. The applicability of these sections is based on CVDF being designated as a nuclear facility under "special facilities," which includes consideration under section 1304, "Plutonium Processing and Handling Facilities," and Section 1324, "Irradiated Fissile Material Storage Facilities."

The Preliminary Safety Evaluation for SNF Project CVDF (WHC-SD-SNF-PSE-003) provides a preliminary hazard analysis and design basis accidents (DBAs). The facility is categorized as a Hazard Category 2 facility in accordance with DOE-STD-1027-92, Hazard Categorization and Accident Analysis Techniques for Compliance with DOE Order 5480.23, Nuclear Safety Analysis Reports. DBAs are defined further in Section 3.5.2. 
HNF-SD-SNF-DRD-002 REV 1

Table 1-1. Process Source Documents.

\begin{tabular}{|c|c|c|}
\hline Document & Title/date & Applicable requirement \\
\hline \multicolumn{3}{|c|}{ DOE orders and federal statutes } \\
\hline DOE Order $5300.1 \mathrm{C}$ & Telecommunications & $\begin{array}{l}\text { General communications system } \\
\text { requirements }\end{array}$ \\
\hline DOE $6430.1 \mathrm{~A}$ & General Design Criteria & See Appendix A. \\
\hline DOE/RL-92-36 & $\begin{array}{l}\text { Hanford Site Hoisting and Rigging } \\
\text { Manual }\end{array}$ & All cranes and hoists in the CVDF \\
\hline \multicolumn{3}{|c|}{ National standards } \\
\hline MIL-STD-1472D & $\begin{array}{l}\text { Human Engineering Design Criteria } \\
\text { for Military Systems, Equipment, and } \\
\text { Facilities }\end{array}$ & Guidelines for Human Factors \\
\hline \multicolumn{3}{|c|}{ Project Hanford Management Contract documents } \\
\hline GH-CLIM-01 & $\begin{array}{l}\text { Design Climate Data for Hanford } \\
\text { Site }\end{array}$ & Data for HVAC system design \\
\hline GC-LOAD-01 & $\begin{array}{l}\text { Standard Architectural-Civil Design } \\
\text { Criteria, Design Loads for Facilities }\end{array}$ & $\begin{array}{l}\text { Structural design criteria for PC-2 } \\
\text { structures }\end{array}$ \\
\hline \multicolumn{3}{|c|}{ SNF and CVDF Project Documents } \\
\hline WHC-SD-SNE-RPT-011 & $\begin{array}{l}\text { Spent Nuclear Fuel Project Design } \\
\text { Basis Capacity Study }\end{array}$ & $\begin{array}{l}\text { Defines overall flow for the set of } \\
\text { processes that make up the project. }\end{array}$ \\
\hline WHC-SD-SNF-PD-011 & $\begin{array}{l}\text { Spent Nuclear Fuel Project } \\
\text { Operational Staffing Plon }\end{array}$ & $\begin{array}{l}\text { Defines projected staffing } \\
\text { requirements for the SNF Project }\end{array}$ \\
\hline WHC-SD-SNF-SUP-003 & SNF Starfup Plon & $\begin{array}{l}\text { Defines projected startup activities for } \\
\text { the SNF Project }\end{array}$ \\
\hline FINF-SD-SNF-CN-027 & $\begin{array}{l}\text { SNF Process Validation } \\
\text { Requirements }\end{array}$ & $\begin{array}{l}\text { Provides CVDF requirements for the } \\
\text { first } 24 \mathrm{MCO} \text { to be processed }\end{array}$ \\
\hline WHC-SD-SNF-DGS-002 & $\begin{array}{l}\text { SNF Equipment and Piping Labeling } \\
\text { Guide }\end{array}$ & $\begin{array}{l}\text { Labeling format requirements for } \\
\text { equipment }\end{array}$ \\
\hline
\end{tabular}

$\mathrm{CVDF}=$ Cold Vacuum Drying Facility.

DOE = U.S. Department of Energy.

HVAC = heating, ventilating, and air conditioning

$\mathrm{MCO}=$ multicanister overpack.

SNF $=$ spent nuclear fuel. 
Table 1-2. Cold Vacuum Drying Facility Safety Requirements Sources.

\begin{tabular}{|c|c|c|}
\hline Document & Title/date & Applicable requirements \\
\hline \multicolumn{3}{|c|}{ DOE orders and federal statutes } \\
\hline DOE Order 5400.5 & $\begin{array}{l}\text { Radiation Protection of the Public and } \\
\text { the Environment }\end{array}$ & DOE radiation exposure guidelines \\
\hline DOE Order 5480.7A & Fire Protection & Facility fire protection \\
\hline DOE Order 5480.24 & Nuclear Criticality Safety & Criticality control \\
\hline DOE Order 5480.28 & $\begin{array}{l}\text { Natural Phenomena Hazards } \\
\text { Mitigation }\end{array}$ & Seismic, wind, tomado and flood \\
\hline DOE Order 6430.1A & General Design Criteria & All SSCs \\
\hline HSRCM-1 & $\begin{array}{l}\text { Hanford Site Radiological Control } \\
\text { Manual }\end{array}$ & $\begin{array}{l}\text { Hanford Site radiation protection } \\
\text { guidelines }\end{array}$ \\
\hline $10 \mathrm{CFR} 835$ & Occuaptional Radiation Protection & Worker radiation protection \\
\hline 29 CFR 1910 & Occupational Safety and Health & OSHA industrial hygiene and safety \\
\hline \multicolumn{3}{|c|}{ Project Hanford Management Contract documents } \\
\hline WHC-CM-4-11 & ALARA Program Manual & $\begin{array}{l}\text { Guidelines for implementing } \\
\text { ALARA }\end{array}$ \\
\hline WHC-CM-4-29 & Nuclear Criticality Safety & $\begin{array}{l}\text { Guidelines for implementing } \\
\text { criticality control }\end{array}$ \\
\hline WHC-CM-4-46 & Safety Analysis Manual & $\begin{array}{l}\text { Guidelines for implementing safety } \\
\text { analyses }\end{array}$ \\
\hline WHC-SD-GN-DGS-30011 & Radiological Design Guide & $\begin{array}{l}\text { Guidlines for implementing } \\
\text { shielding }\end{array}$ \\
\hline \multicolumn{3}{|c|}{ SNF and CVDF Project documents } \\
\hline WHC-SD-SNF-PSE-003 & $\begin{array}{l}\text { Preliminary Safety Evaluation for the } \\
\text { Spent Nuclear Fuel Project Cold } \\
\text { Vacuum Drying Facility }\end{array}$ & $\begin{array}{l}\text { Facility hazard category, } \\
\text { DBAs, and safety classifications }\end{array}$ \\
\hline WHC-SD-SNF-DB-003 & $\begin{array}{l}\text { Spent Nuclear Fuel Project Path } \\
\text { Forward, Additional NRC } \\
\text { Requirements }\end{array}$ & $\begin{array}{l}\text { NRC equivalency design } \\
\text { requirements }\end{array}$ \\
\hline WHC-SD-SNF-DB-010 & $\begin{array}{l}\text { Cold Vacuum Drying System Natural } \\
\text { Phenomena Hazards }\end{array}$ & \\
\hline WHC-SD-SNF-FHA-003 & $\begin{array}{l}\text { Preliminary Fire Hazard Analysis for } \\
\text { the Cold Vacuum Drying System } \\
\text { Facility } 142 K\end{array}$ & Fire protection requirements \\
\hline HNTF-SD-SNF-CSER-005 & $\begin{array}{l}\text { Criticality Safety Evaluation Report } \\
\text { for Spent Nuclear Fuel Processing } \\
\text { and Storage Facilities }\end{array}$ & Criticality safety requirements \\
\hline
\end{tabular}

ALARA $=$ as low as reasonably achievable.

CVDF $=$ Cold Vacuum Drying Facility.

$\mathrm{DBA}=$ design basis accident.

DOE = U.S. Department of Energy.

OSHA = Occupational Safety and Health Administration.

SNFP = Spent Nuclear Fuel Project.

SSC = structure, system, and component. 
Worker radiation exposure safety within the plant is defined by HSRCM-1, Hanford Site Radiological Controlled Manual; 10 CFR 20, "Standards for Protection Against Radiation," equivalency; 10 CFR 835, "Occupational Radiation Protection;" and DOE N5480.6, DOE RadCon Manual. Of these the DOE N5480.6 is the most comprehensive and restrictive document. A program to achieve radiation exposure as low as reasonably achievable (ALARA) with an administrative control limitation of $500 \mathrm{mrem} / \mathrm{yr}$ per person is the stated whole body exposure criterion in HSRCM-1 and DOE N5480.6. 10 CFR 835 defines the DOE ALARA design target as $1.0 \mathrm{rem} / \mathrm{yr}$. 10 CFR 20 and DOE Order 5480.11, Radiation Protection for Occupational Workers, state the maximum allowable annual exposure is $5 \mathrm{rem}$. Thus the two ALARA design targets are $10 \%$ and $20 \%$ of the maximum allowable value. The CVDF design criterion will the DOE N5480.6 value (500 mrem) unless features required to achieve this value prove to be unreasonable (in which case the 10 CFR 835 and DOE Order 5480.11 limit of 1.0 rem will be observed).

It is the goal of the CVDF project to achieve "NRC equivalency." Interpretation of the application and appropriateness of specific NRC regulations and guidelines also depends upon knowledge of the design concept and preliminary hazards assumptions. HNF-SD-SNF-DB-003, Spent Nuclear Fuel Project Path Forward, Additional NRC Requirements, provides for additional NRC equivalency requirements. An applicability assessment of the NRC equivalency requirements is provided in Appendix B.

For these reasons, the definition of criteria and design concepts must be completed simultaneously and iteratively, in conjunction with hazard assessment, so that the design team can make decisions that will control the criteria that are applicable. The purpose of this document is to report the key criteria (and associated interpretations) that are deemed appropriate for the CVDF when concurrently developing the conceptual design and the preliminary hazards assessment. Assumptions are required in order to proceed with the conceptual definition of the CVDF. Formal safety analysis is required to verify or modify these assumptions. This report should be considered to be a living document in the sense that it should be revisited and updated as the design and safety analysis processes progress.

\subsubsection{Environmental Compliance Source Documents}

The documents listed in Table 1-3 shall be used in determining whether the CVDF complies with all applicable state and federal environmental regulations.

\subsubsection{Quality Assurance Source Documents}

The documents listed in Table 1-4 shall be used in developing quality assurance procedures for the control of the CVDF design activities. 
Table 1-3. Environmental Compliance Source Documents.

\begin{tabular}{|c|c|c|}
\hline Document & Title/date & Applicable requirement \\
\hline \multicolumn{3}{|c|}{ DOE orders and documents } \\
\hline DOE Order 5400.5 & $\begin{array}{l}\text { Radiation Protection of the Public } \\
\text { and the Environment }\end{array}$ & $\begin{array}{l}\text { SAR assessments and general CVDF } \\
\text { environmental compliance }\end{array}$ \\
\hline DOE $6430.1 \mathrm{~A}$ & General Design Criteria & See Appendix A. \\
\hline DOE/RL-96-47 & $\begin{array}{l}\text { US EPA Clean Air Act Notice of } \\
\text { Construction for the SNFP CVDF, } \\
\text { Project W-441 }\end{array}$ & NOC for CVDF \\
\hline DOE/RL-96-5S & $\begin{array}{l}\text { State of Washington Dept. of Ecology } \\
\text { Criteria Pollutants and Toxic Air } \\
\text { Pollutants Phase I Notice of } \\
\text { Construction for the Hanford Site } \\
\text { SNFP CVDF, Project W-44I }\end{array}$ & NOC for CVDF \\
\hline DOE/RL-96-54 & $\begin{array}{l}\text { State of Washington Dept. of Health } \\
\text { Notice of Construction for the } \\
\text { Honford Site SNFP CVDF, Project } \\
W-44 I\end{array}$ & NOC for CVDF \\
\hline DOE/RL-96-100 & $\begin{array}{l}\text { State of Washington Dept. of Ecology } \\
\text { Toxic Air Pollutants Phase II Notice } \\
\text { of Construction for the Hanford Site } \\
\text { SNFP CVDF, Project W-44I }\end{array}$ & NOC for CVDF \\
\hline \multicolumn{3}{|c|}{ Washington Administrative Codes } \\
\hline WAC $51-11$ & Washington State Energy Code & \\
\hline WAC $173-303$ & Dangerous Waste Regulations & $\begin{array}{l}\text { Modification, instaliation of new } \\
\text { equipment }\end{array}$ \\
\hline WAC $173-400$ & $\begin{array}{l}\text { General Regulations for Air Pollution } \\
\text { Sources }\end{array}$ & Use in preparation of $\mathrm{NOC}$ \\
\hline WAC $173-460$ & $\begin{array}{l}\text { Controls for New Sources of Toxic } \\
\text { Air Emissions }\end{array}$ & NOC \\
\hline WAC $173-460-040(8)$ & Commencement of Construction & NOC \\
\hline WAC $246-247$ & Radiation Protection - Air Emissions & NOC \\
\hline \multicolumn{3}{|c|}{ Project Hanford Management Contract documents } \\
\hline WHC-CM-7-5 & Environmental Compliance Manual & $\begin{array}{l}\text { Guidelines for compliance with state } \\
\text { and federal regulations }\end{array}$ \\
\hline
\end{tabular}

DOE $=$ U.S. Department of Energy.

CVDF $=$ Cold Vacuum Drying Facility.

NOC $=$ Notice of Construction

$\mathrm{SAR}=$ safety analysis report. 
Table 1-4. Quality Assurance Source Documents.

\begin{tabular}{|c|c|c|}
\hline Document & Title/date & Applicable requirement \\
\hline \multicolumn{3}{|c|}{ DOE orders and federal statutes } \\
\hline 10 CFR 830.120 & $\begin{array}{l}\text { Nuclear Safety Management, Quality } \\
\text { Assurance Requirements }\end{array}$ & See Section 4.0 of the CVDF DRD \\
\hline 10 CFR 72, Subpart G & $\begin{array}{l}\text { Licensing Requirements for the } \\
\text { Independent Storage of Spent Nuclear } \\
\text { Fuel and High Level Radioactive } \\
\text { Waste, Quality Assurance }\end{array}$ & CVDF Safety class SSCs \\
\hline DOE $6430.1 \mathrm{~A}$ & General Design Criteria & See Appendix A. \\
\hline DOE/RW/0333P & $\begin{array}{l}\text { Quality Assurance Requirements and } \\
\text { Description }\end{array}$ & (See HNF-SD-SNF-RPT-007) \\
\hline \multicolumn{3}{|c|}{ Project Hanford Management Contract documents } \\
\hline HNF-MP-599 (valid after 10/3079) & $\begin{array}{l}\text { Project Hanford Quality Assurance } \\
\text { Program Description }\end{array}$ & SNF Project \\
\hline HNF-SP-1228 & $\begin{array}{l}\text { Quality Assurance Program } \\
\text { Implementation Plan for Nuclear } \\
\text { Facilities }\end{array}$ & SNF Project \\
\hline \multicolumn{3}{|c|}{ SNF and CVDF Project documents } \\
\hline HNF-SD-SNE-QAPP-004 & $\begin{array}{l}\text { Spent Nuclear Fuel Project Quality } \\
\text { Assurance Program Plan }\end{array}$ & SNE Project \\
\hline WHC-SD-W441-QAPP-00I & $\begin{array}{l}\text { Quality Assurance Program Plan } \\
\text { Project W-44 I Spent Nuclear Fuel } \\
\text { Cold Vacuum Drying Facility }\end{array}$ & CVDF Project \\
\hline HNF-SD-SNF-DB-003 & $\begin{array}{l}\text { SNFP Path Forward Additional NRC } \\
\text { Requirements }\end{array}$ & CVDF safety-class SSCs \\
\hline WHC-SD-SNF-RPT-007 & $\begin{array}{l}\text { Application OfThe Office of Civilian } \\
\text { Radioactive Waste Management } \\
\text { Quality Assurance Requirements To } \\
\text { The Hanford Spent Nuclear Fuel } \\
\text { Project }\end{array}$ & SNF Project \\
\hline
\end{tabular}

$\mathrm{CVDF}=$ Cold Vacuum Drying Facility.

DOE $=$ U.S. Department of Energy.

$\mathrm{DRD}=$ DesignRrequirements Document.

SNFP = Spent Nuclear Fuel Project.

$\mathrm{SSC}=$ structure, system, and component. 
HNF-SD-SNF-DRD-002 REV 1

\subsection{REFERENCES}

10 CFR 20, "Standards for Protection Against Radiation," Code of Federal Regulations, as amended.

10 CFR 30.12, "Persons Using Byproduct Material Under Certain Department of Energy and Nuclear Regulatory Commission Contracts," Code of Federal Regulations, as amended.

10 CFR 72, "Licensing Requirements for the Independent Storage of Spent Nuclear Fuel and High-Level Radioactive Waste," and Subpart G, "Quality Assurance," Code of Federal Regulations, as amended.

10 CFR 830, "Nuclear Safety Management," Section 830.120, "Quality Assurance Requirements," Code of Federal Regulations, as amended.

10 CFR 835, "Occupational Radiation Protection," Code of Federal Regulations, as amended.

10 CFR 930.120, "Nuclear Safety Management," Code of Federal Regulations, as amended.

29 CFR 1910, "Occupational Safety and Health," Code of Federal Regulations, as amended.

DOE N5480.6, DOE RadCon Manual, U.S. Department of Energy, Washington, D.C.

DOE Order 5300.1C, 1992, Telecommunications, U.S. Department of Energy, Washington, D.C.

DOE Order 5400.5, 1993, Radiation Protection of the Public and the Environment, U.S. Department of Energy, Washington, D.C.

DOE Order 5480.7A, 1993, Fire Protection, U.S. Department of Energy, Washington, D.C.

DOE Order 5480.11, 1988, Radiation Protection for Occupational Workers, U.S. Department of Energy, Washington, D.C.

DOE Order 5480.24, 1992, Nuclear Criticality Safety, U.S. Department of Energy, Washington, D.C.

DOE Order $5480.28,1993$, Natural Phenomena Hazards Mitigation, U.S. Department of Energy, Washington, D.C.

DOE Order 6430.1A, 1989, General Design Criteria, U.S. Department of Energy, Washington, D.C.

DOE/RL-92-36, 1993, Hanford Site Hoisting and Rigging Manual, U.S. Department of Energy, Richland Operations Office, Richland, Washington. 


\section{HNF-SD-SNF-DRD-002 REV 1}

DOE/RL-96-47, 1996, U.S. Environmental Protection Agengy Clean Air Act Notice of Construction for the Spent Nuclear Fuel Project-Cold Vacuum Drying Facility, Project W-44I, U.S. Department of Energy, Richland Operations Office, Richland, Washington.

DOE/RL-96-54, 1996, State of Washington Department of Health Notice of Construction for the Hanford Site SNFP CVDF, Project W-44I, U.S. Department of Energy, Richland Operations Office, Richland, Washington.

DOE/RL-96-55, 1997, State of Washington Department of Ecology Criteria Pollutants and Toxic Air Pollutants Phase I Notice of Construction for the Hanford Site Spent Nuclear Fuel Project-Cold Vacuum Drying Facility, Project W-44I, U.S. Department of Energy, Richland Operations Office, Richland, Washington.

DOE/RL-96-100, 1996, State of Washington Department of Ecology Toxic Air Pollutants Phase II Notice of Construction for the Hanford Site SNFP CVDF, Project W-44I, U.S. Department of Energy, Richland Operations Office, Richland, Washington.

DOE/RW/0333P, 1996, Quality Assurance Requirements and Description, Office of Civilian Radioactive Waste Management, U.S. Department of Energy, Washington, D.C.

DOE-STD-1027-92, Hazard Categorization and Accident Analysis Techniques for Compliance with DOE Order 5480.23, Nuclear Safety Analysis Reports, U.S. Department of Enery, Washington, D.C.

GC-LOAD-01, Standard Architectural-Civil Design Criteria, Design Loads for Facilities, ICF Kaiser Hanford, Richland, Washington.

GH-CLMM-01, Design Climate Data for Hanford Site, ICF Kaiser Hanford, Richland, Washington.

HNF-MP-599, 1997, Project Hanford Quality Assurance Program Description, Rev. 0, Fluor Daniel Hanford, Incorporated, Richland, Washington.

HNF-S-0435, 1997, Performance Specification for the K-Basin Spent Nuclear Fuel Cold Vacuum Drying Facility, Rev. 1, Fluor Daniel Hanford, Incorporated, Richland, Washington.

HNF-SD-SNF-CN-027, SNF Process Validation Requirements, Fluor Daniel Hanford, Incorporated, Richland, Washington.

HNF-SD-SNF-CSER-005, 1997, Criticality Safety Evaluation Report for Spent Nuclear Fuel Processing and Storage Facilities, Rev. 3, Fluor Daniel Hanford, Incorporated, Richland, Washington. 


\section{HNF-SD-SNF-DRD-002 REV 1}

HNF-SD-SNF-DB-003, 1997, Spent Nuclear Fuel Project Path Forward, Additional NRC Requirements, Rev. 3, Fluor Daniel Hanford, Incorporated, Richland, Washington.

HNF-SD-SNF-QAPP-004, 1997, Spent Nuclear Fuel Project Quality Assurance Program Plan, Rev. 1, Fluor Daniel Hanford, Incorporated, Richland, Washington.

HNF-SP-1228, Quality Assurance Program Implementation Plan for Nuclear Facilities, Fluor Daniel Hanford, Incorporated, Richland, Washington.

HSRCM-1, 1994, Hanford Site Radiological Control Manual, Rev. 2, Westinghouse Hanford Company, Richland, Washington.

Lytle, J. E., 1994, Approval of Path Forward for N Reactor Spent Fuel Interim Storage, (Memorandum to T. P. Grumbly, U.S. Department of Energy, Washington, D.C., November 9), U.S. Department of Energy, Washington, D.C.

MII-STD-1472D, Human Engineering Design Criteria for Military Systems, Equipment, and Facilities, U.S. Department of Defense, Washington, D..

Swenson, J. A., 1996, Technical Issues Management Board Decision Memorandum No. 4 Cold Vacuum Drying Location (Letter 2002-PI-96-004 to J. C. Fulton, Westinghouse Hanford Company, January 29), Westinghouse Hanford Company, Richland, Washington.

Tri-Party Agreement, 1994, Hanford Federal Facility Agreement and Consent Order, as amended, Washington State Department of Ecology, U.S. Environmental Protection Agency, and U.S. Department of Energy, Olympia, Washington.

WAC 51-11, "Washington State Energy Code," Washington Administrative Code, as amended.

WAC 173-303, 1995, "Dangerous Waste Regulations," Washington Administrative Code, as amended.

WAC 173-400, 1995, "General Regulations for Air Pollution Sources," Washington Administrative Code, as amended.

WAC 173-460, 199,5 "Controls for New Sources of Toxic Air Emissions," Washington Administrative Code, as amended.

WAC 173-460-040(8), 1995, "Commencement of Construction," Washington Administrative Code, as amended.

WAC 246-247, 1995, "Radiation Protection - Air Emissions," Washington Administrative Code, as amended. 
HNF-SD-SNF-DRD-002 REV 1

WHC-CM-4-11, ALARA Program Manual, Westinghouse Hanford Company, Richland, Washington.

WHC-CM-4-29, 1997, Nuclear Criticality Safety, Westinghouse Hanford Company, Richland, Washington.

WHC-CM-4-46, Safety Analysis Manual, Westinghouse Hanford Company, Richland, Washington.

WHC-CM-7-5, 1996, Environmental Compliance Manual, Westinghouse Hanford Company, Richland, Washington.

WHC-SD-GN-DGS-30011, 1994, Radiological Design Guide, Rev. 0, Westinghouse Hanford Company, Richland, Washington.

WHC-SD-SNF-DB-010, 1996, Cold Vacuum Drying System Natural Phenomena Hazards, Rev. 1, Westinghouse Hanford Company, Richland, Washington.

WHC-SD-SNF-DGS-002, 1996, Spent Nuclear Fuel Project Equipment and Piping Labeling Guide, Rev. 0, Westinghouse Hanford Company, Richland, Washington.

WHC-SD-SNF-FHA-003, 1996, Preliminary Fire Hazard Analysis for the Cold Vacuum Drying System Facility, Rev. 0, Westinghouse Hanford Company, Richland, Washington.

WHC-SD-SNF-FRD-020, 1996, K Basin Spent Nuclear Fuel Cold Vacuum Drying Facility Functions and Requirements, Rev. 0, Westinghouse Hanford Company, Richland, Washington.

WHC-SD-SNF-PD-011, 1996, Spent Nuclear Fuel Project Operational Staffing Plan, Rev. 1, Westinghouse Hanford Company, Richland, Washington.

WHC-SD-SNF-PMP-011, 1995, Spent Nuclear Fuel Project, Project Management Plan, Rev. 0, Westinghouse Hanford Company, Richland, Washington.

WHC-SD-SNF-PSE-003, 1996, Preliminary Safety Evaluation for the Spent Nuclear Fuel Project's Cold Vacuum Drying System, Rev. 0, Westinghouse Hanford Company, Richland, Washington.

WHC-SD-SNF-RPT-007, 1996, Application of the Office of Civilian Radioactive Waste Management Quality Assurance Requirements to the Hanford Spent Nuclear Fuel Project, Rev. 0, Westinghouse Hanford Company, Richland, Washington.

WHC-SD-SNF-RPT-011, 1996, Spent Nuclear Fuel Project Design Basis Capacity Study, Rev. 0, Westinghouse Hanford Company, Richland, Washington. 
WHC-SD-SNF-SD-005, 1996, Spent Nuclear Fuel Project technical Baseline Description, Westinghouse Hanford Company, Richland, Washington.

WHC-SD-SNF-SUP-003, SNF Startup Plan, Westinghouse Hanford Company, Richland, Washington.

WHC-SD-SNF-TI-016, Development of Design Basis Capacity for SNF Project Systems, Rev. 1, Westinghouse Hanford Company, Richland, Washington.

WHC-SD-W441-QAPP-001, 1996, Quality Assurance Program Plan Project W-441 Spent Nuclear Fuel Cold Vacuum Drying Facility, Rev. 0, Westinghouse Hanford Company, Richland, Washington.

Drawings:

H-1-81166, SNF Project K Basin SNF Vacuum Drying Level 1 PFD, Rev.

H-2-825868, SNF Project Level o Process Flow Diagram, Rev. 1 
HNF-SD-SNF-DRD-002 REV 1

This page intentionally left blank. 
HNF-SD-SNF-DRD-002 REV 1

\subsection{PROCESS AND FACILITY FUNCTIONAL REQUIREMENTS}

\subsection{BACKGROUND}

The scope of this section is to discuss the process and facility requirements for the CVDF as determined by analysis, experimentation and overall SNF Project requirements. The cold vacuum drying process represents the first of the two drying steps required to support dry fuel storage. As shown on Figure 2-1, fuel is loaded into MCOs at each of the K Basins and transferred to the CVDF in a flooded condition in transportation casks. The cold vacuum drying process removes free (or bulk liquid) water from the MCO prior to transport to the CSB where the MCO is staged, processed through the second drying step, and stored. The CVDF subproject mission is to receive the MCOs, drain the bulk water, remove residual water by vacuum drying, and then backfill the MCO with an inert gas, helium. This will minimize the presence of constituents that react with uranium metal and metal hydrides in the fuel elements, inhibiting the corrosion process and providing interim stabilization for the fuel. Once complete, the $\mathrm{MCO}$ will be transported to the CSB. The requirement is to remove sufficient free water from inside the MCOs to allow transportation of the MCOs from the $\mathrm{K}$ Basins to the CSB in a sealed configuration without overpressurization.

Residual water is the primary constituent that limits the MCO storage time. This is due to continued decomposition by reaction with uranium metal and radiolysis, both causing the MCO pressure to increase. Water can exhibit three different drying characteristic, depending on how it is associated with solid materials in the MCO. These characteristics are described as follows.

- Free water - water present in the MCO as a liquid that is not chemically bonded to any substrate material and exhibits the normal vapor pressure of water. This includes water contained in the interstitial regions of particulate material or fuel element crevices.

- Hydration water - water present in the MCO that is distributed throughout the crystalline and amorphous structures of residual fuel corrosion products.

- Chemisorbed water - water present in the MCO as a surface phenomenon of solid substrates, such as uranium oxide.

Figure 2-2 qualitatively indicates that more extreme conditions are required to remove residual water as the strength of chemical bonds between water molecules and solid substrates increases. The operating conditions used in the cold vacuum drying process are not intended to produce a product that can be stored in the CSB over the entire storage period defined in the SNF Project goals ( 40 years extendable to 75 years). Achieving this goal depends on removing additional water from the fuel packaged in MCOs by hot conditioning (the second drying step) or other means. 
Figure 2-1. Cold Vacuum Drying Facility Relationship to Other Spent Nuclear Fuel Project Systems.

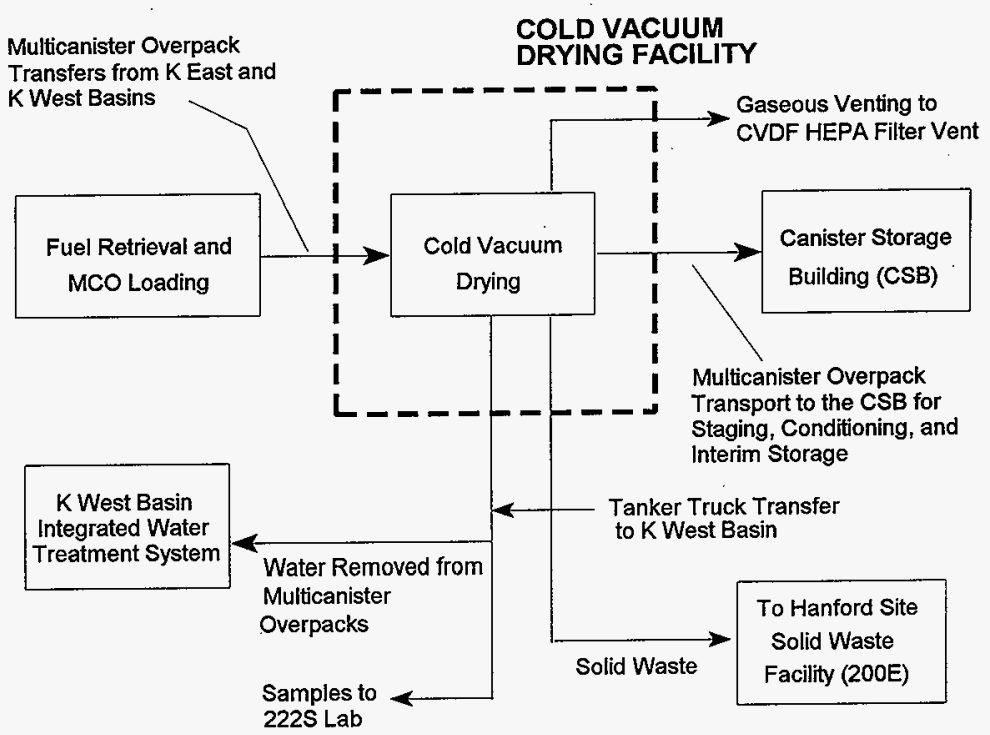


From WHC-SD-SNF-RPT-010, Spent Nuclear Fuel Project Operational Description, the general operational sequence for the cold vacuum drying process shall be as follows:

- A general exhaust system shall control process bay air flow control and maintain a process bay negative pressure differential with respect to the areas external to the process bay.

- Upon receipt of the MCO and transporter at the CVDF, the process bay transporter door must be opened. The heating, ventilating, and air conditioning (HVAC) systems shall be placed into a standby mode to keep from "cycling" the process bay dampers and the system fans attempting to maintain negative process bay pressure.

- As the transporter tractor is nearing entry into the CVDF bay, an exhaust boot shall be attached to the tractor exhaust. The exhaust boot is directed outside maintaining indoor air quality.

- After the transporter tractor has been decoupled and removed from the facility, the process bay door is closed and confinement is reestablished by returning the HVAC systems to normal operation mode.

- A local exhaust ventilation connection is made to the cask to check and bleed off any pressurized gas.

- The cask lid is removed and a local exhaust hood is installed over the cask-MCO to provide primary confinement release collection from the MCO.

- Backdraft dampers shall be installed in all HVAC dampered inlets and outlets to the process bay to help prevent the spread of contamination in the event of a process bay overpressurization.

- In the event of a facility shutdown or a facility or process bay loss of electrical power or loss of control air, all process bay dampers shall fail closed to maintain process bay confinement.

- The process bays confinements hall remain operational during CVDF normal operation periods.

- Transport cask-MCO into CVDF process bay, achieve confinement and secure cask transporter to the floor if required. The MCO will contain SNF covered with water; there will be a helium cover gas over the fuel. The MCO will be vented to the sealed cask through the MCO high-efficiency particulate air (HEPA) filter port. The cask annulus will contain deionized water.

- Check and bleed off cask pressure into vent system. 
Figure 2-2. Generalized Description of Water Removal from a Multicanister Overpack.

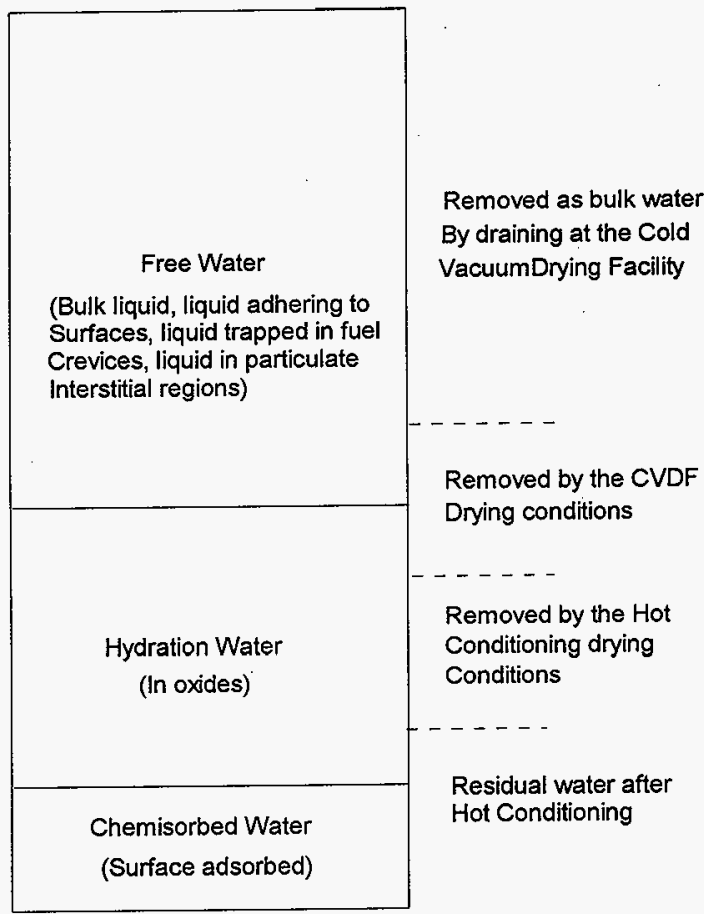


- Replace the cask lid with a seal ring and hood assembly, which seals the annulus between the MCO and the cask and which allows access to the MCO ports where process connections may be made.

- Connect lines to the cask so that the MCO can be heated or cooled by water flowing through the annulus between the cask and the MCO.

- Connect and check the drying process system lines to the MCO, and inert the MCO with helium.

- Establish warm water flow through the annulus and allow the MCO, filled with water, to warm to $50^{\circ} \mathrm{C}\left(122^{\circ} \mathrm{F}\right)$.

- Purge the MCO with helium using the short process tube to purge the headspace and verify flow path. Purge the MCO by cyclic pressurization of the $\mathrm{MCO}$ and venting out through the vacuum drying system.

- Draw the bulk water out of the MCO into a receiving vessel and cleanup system.

- Purge dry helium through the MCO to evaporate residual water and remove any hydrogen or other gases generated from the SNF by the cold vacuum drying process.

- Draw a vacuum in the MCO to evaporate residual water.

- Cycle between gas purge and evacuation according to a programmable recipe until the $\mathrm{MCO}$ interior reaches the acceptance criteria.

- Isolate the MCO and measure the rate of pressure rise (rebound test) to determine whether more drying is needed.

- Repeat gas purge and evacuation steps until an acceptable rate of pressure rise is achieved.

- Inert the MCO with helium to a pressure of $101 \mathrm{kPa}$ (1 atm) and then heat the MCO to $75^{\circ} \mathrm{C}\left(167^{\circ} \mathrm{F}\right)$ and monitor the offgas make-up for shipping acceptance test.

- Cool the $\mathrm{MCO}$ and its contents to $15^{\circ} \mathrm{C}\left(59^{\circ} \mathrm{F}\right)$.

- Fill the $\mathrm{MCO}$ with helium to a maximum gauge pressure of $21 \mathrm{kPa}\left(3 \mathrm{lbf} / \mathrm{in}^{2}\right)$.

- Disconnect the lines to the MCO and seal the MCO in accordance with the requirements found in WHC-SD-SNF-SARP-017, Safety Analysis Report for Packaging (Onsite) Multicamister Overpack Cask. 
- Drain and purge the annulus between the MCO and the cask with a dry gas (instrument air) to dry the annulus. Remove seal ring and process hood and reinstall the cask lid.

- Fill the annulus with helium to a maximum gauge pressure of $21 \mathrm{~Pa}\left(3 \mathrm{lbf} / \mathrm{in}^{2}\right)$.

- Disconnect the lines to the cask. Release cask-MCO for shipment to the CSB.

The general operational sequence for the MCO water removal and cleanup process shall be as follows.

- Draw the bulk water out of the MCO into a critically safe receiving vessel (vessel inner diameter of $595 \mathrm{~mm}$ [23.5 in.] or less). The average MCO will have approximately $0.57 \mathrm{~m}^{3}$ (150 gal) of water contaminated with fuel corrosion products, particulate, and ions in solution.

- Receiving vessel as used for the MCO bulk water.

- Transfer water from the cold vacuum drying equipment, removed during the purge and evacuation operations, to the receiving vessel. Flush transfer lines with deionized water into the receiving vessel.

- The cleanup system shall be critically safe. The cleanup system shall remove fuel corrosion products to low specific activity quantities (Appendix C). Sampling of the water before and after the cleanup stage shall be performed to determine ion exchange/filter media loading and to verify that low specific activity quantity material is produced.

- Transfer the processed water to a large holding tank. When sufficient water is collected, transfer water from the holding tank to a tanker truck for transport to the KW-Basin Integrated Water Treatment System (IWTS) System.

- When the ion exchange media and filter are loaded to its administrative limit (based upon nontransuranic [TRU] quantity), the media will be will be shipped to the Solid Waste Facility at the Hanford Site's 200 East Area.

Figure 2-3 provides a summary of water masses to be removed from a nominal Mark IV MCO. Bulk water removal is described above. Residual bulk water is defined as liquid water held in cupped regions of the solid materials contained by an MCO and held on surfaces by surface tension. This water is free to rapidly establish an equilibrium water vapor pressure in an MCO. A nominal MCO is projected to contain approximately $10 \mathrm{~kg}(22 \mathrm{lb})$ of residual bulk water after draining. However, the quantity of residual bulk water in a specific MCO will vary with the fuel condition. If an MCO contains only pristine fuel (no scrap basket), the residual bulk water is estimated to be approximately $5 \mathrm{~kg}(11 \mathrm{lb})$. Upper bound estimates for residual bulk water 


\section{HNF-SD-SNF-DRD-002 REV 1}

Figure 2-3. Water Removed by Fuel Drying (Masses Based on a Nominal Mark IV Multicanister Overpack).

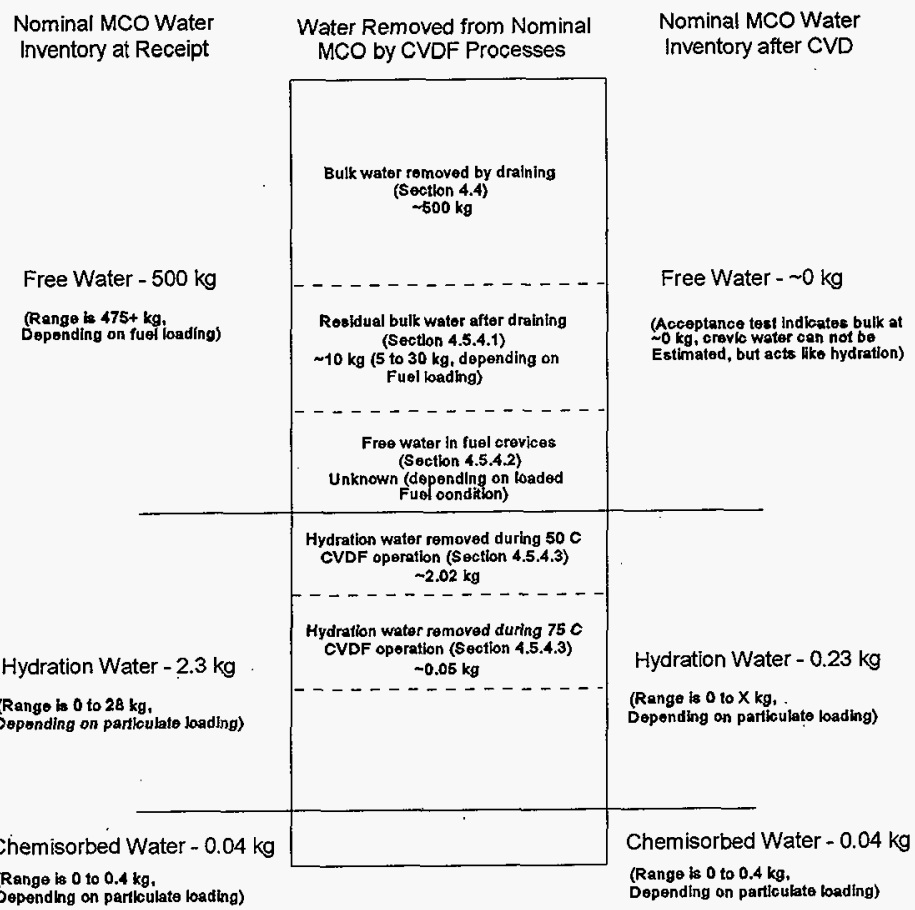


depend on the condition of fuel loaded. Assuming an MCO contains a scrap basket and each element contains a damaged end facing up to form a 51 -mm (2-in.) cupped region filled with water, the residual bulk water can be estimated to be as high as $32 \mathrm{~kg}(71 \mathrm{lb})$.

Corrosion reactions causing pressurization of the MCO must be assumed to be generating hydrogen. The potential also exists for generation of hydrogen and oxygen from radiolytic decomposition of water. However, the rate of water radiolysis does not produce significant gas quantities during time frames allowed for basin to CVDF transfers (see HNF-SD-SNF-TM-001). Therefore, gases within the cask-MCO are treated as mixtures of helium and hydrogen. The mass and composition of these gases are described in Section 2.3.1. Details on the other characteristics of the MCO contents (e.g., masses, radionuclides) are presented in Section 2.3.1

\subsection{PROCESS AND FACILTTY FUNCTIONAL REQUIREMENTS}

\subsubsection{Facility Processing Mission Goals}

a. The total number of MCOs to be processed shall be 430-225 from the K East Basin and 205 from the $\mathrm{K}$ West Basin.

b. The project design basis startup schedule shall be 6 months, with a 6-month startup from the $\mathrm{K}$ West Basin and a 3-month lag before a 3-month startup of $\mathrm{K}$ East Basin. Both basins shall achieve peak shipment operations 6 months after startup.

c. The peak shipment design basis capacity shall be 0.70 transport casks per day (i.e., approximately 5 total shipments per week for both basins).

d. The facility shall be available for processing 7 days a week, 3 shifts per day, for 340 working days per year.

e. The CVDF shall be designed to achieve processing of all $430 \mathrm{MCO}$ in a 2-year time period including startup.

f. A facility reliability-availability-maintainability evaluation shall be provided and documented to show the facility systems and operations can meet the processing mission goals.

\subsubsection{Receipt of Cask-Multicanister Overpack}

a. The CVDF shall provide a method of receipt and positioning of the cask-MCO transporter. 
- The CVDF shall receive MCOs filled with water and SNF. The MCOs will be contained within a shield cask that will be riding on a transporter trailer.

- The CVDF shall have processes implemented by process equipment systems that shail remove the bulk (liquid) water from the $\mathrm{MCO}$, dry (evaporate) the residual free water clinging to the SNF and MCO interior surfaces, decompose readily releasable waters of hydration, verify acceptable SNF dryness, perform a shipping acceptance test, prepare the cask-MCO for shipment to the CSB and prepare waste water for transport to the KW-Basin IWTS.

b. A method shall be provided to survey and decontaminate the top of the cask to safe, allowable levels.

c. The CVDF shall provide a method of securing (if required) the cask-MCO transporter in position for MCO processing. An evaluation of the tie-down system shall be performed to determine whether translation of the trailer impacts safety-class systems.

d. A method shall be provided to remove the cask cover to access the MCO. The cask shall be vented to HEPA filters prior to removal of the cask lid.

e. A method shall be provided to survey and decontaminate the top of the MCO to safe, allowable levels.

\subsubsection{Cold Vacuum Drying Process Requirements}

a. A method shall be provided to connect and disconnect the drying process system to the MCO.

b. A method shall be provided to drain the bulk water from the $\mathrm{MCO}$ to the process water collection (PWC) system.

c. A method shall be provided to remove the residual free water (and weakly bound hydration water) by evacuating the MCO.

d. A method shall be provided to recirculate helium through the MCO to assist the drying process. The system shall support a single-pass (purge) flow path or circulation through a loop containing a condenser.

e. The process system shall be capable of demonstrating free water removal at the conclusion of drying cycles by evacuating the MCO to less than $67 \mathrm{~Pa}(0.5$ torr) and monitoring the closed system pressure for up to 1 hour. The acceptance criterion is a $400-\mathrm{Pa}$ (3-torr) pressure rise, or less, in 1 hour from a base pressure of $67 \mathrm{~Pa}$ (0.5 torr). 
f. The process system shall be capable of demonstrating a pressure rise in an MCO measured at $75^{\circ} \mathrm{C}\left(167^{\circ} \mathrm{F}\right)$ is less than $1.4 \mathrm{kPa} / \mathrm{hr}\left(0.2 \mathrm{lbf} / \mathrm{in}^{2}\right.$ per hour $)$.

g. Gas sampling and analysis capability shall be provided to monitor the gases drawn from the MCO. Hydrogen, helium, water vapor, air, and krypton are the gases that shall be identified and the gas generation or flow rates shall be measured.

h. The introduction of halogenated oils, or oils with a low-vapor pressure at conditioning temperatures (e.g., $350^{\circ} \mathrm{C}\left[662^{\circ} \mathrm{F}\right]$ ), into an $\mathrm{MCO}$ shall be precluded during $\mathrm{MCO}$ processing.

i. The CVDF process design shall observe the following constraints to ensure maintaining the MCO structural integrity (HNNF-SD-SNF-DR-003).

- The internal design pressure of the $\mathrm{MCO}$ is a gauge pressure of $1.0 \mathrm{MPa}$ $\left(150 \mathrm{lbf} / \mathrm{in}^{2}\right)$.

- The $\mathrm{MCO}$ design maximum temperature is $375^{\circ} \mathrm{C}\left(707^{\circ} \mathrm{F}\right)$ and the design operating temperature is $350^{\circ} \mathrm{C}\left(662^{\circ} \mathrm{F}\right)$.

- The design thermal transient under normal conditions is $100^{\circ} \mathrm{C} / \mathrm{hr}\left(180^{\circ} \mathrm{F} / \mathrm{hr}\right)$ from $20^{\circ} \mathrm{C}$ to $350^{\circ} \mathrm{C}\left(68^{\circ} \mathrm{F}\right.$ to $\left.662{ }^{\circ} \mathrm{F}\right)$ over a maximum of five cycles.

- The design maximum temperature for fuel inside the $\mathrm{MCO}$ is $300^{\circ} \mathrm{C}\left(572^{\circ} \mathrm{F}\right)$.

- The design maximum temperature gradient between the $\mathrm{MCO}$ shell and $\mathrm{MCO}$ shield plug center is $100^{\circ} \mathrm{C}\left(212^{\circ} \mathrm{F}\right)$.

\subsubsection{Tempered Water System Requirements}

a. A method shall be provided to install a cask sealing ring to maintain cask annulus water at the top of the cask-MCO annulus region.

b. A method shall be provided to connect and disconnect the tempered water system (TWS) to the cask lower port.

c. A method shall be provided to control MCO temperature by a closed loop heating and cooling system that recirculates temperature controlled water through the annular region formed by the exterior MCO and cask cavity walls.

d. A method shall be provided to control the system temperature in the range of $10^{\circ} \mathrm{C}$ to $85^{\circ} \mathrm{C}\left(122^{\circ} \mathrm{F}\right.$ to $\left.185^{\circ} \mathrm{F}\right)$. 
e. Maximum pressure within the MCO cask annulus shall not exceed a gauge pressure of $276 \mathrm{kPa}\left(40 \mathrm{lbf} / \mathrm{in}^{2}\right)$.

\subsubsection{Process Water Conditioning Requirements}

a. A process water conditioning (PWC) system shall be implemented to transfer the water from the MCO to a critically safe receiver tank. Process water shall be any water removed from the MCO and/or system decontamination activities.

b. The MCO process water cleanup system shall conditioning the water such that transport of the water to KW-Basin IWTS shall be low specific activity quantities, or less, as defined in Appendix C.

c. The MCO process water cleanup system shall not produce TRU quantities in any ion exchange media.

\subsubsection{Process Controls Requirements}

a. There shall be a facility control system that interfaces with all process and facility systems for control and monitoring functions.

b. This system shall provide a central location for preprogrammed sequential operations, alarm response, and data management.

c. The control system shall be of a distributive design that places interfaces near the process that is being controlled or monitored.

\subsubsection{Cask-Multicanister Overpack Release from Cold Vacuum Drying Facility}

a. A method shall be provided to verify the integrity of the cask and MCO seals.

b. A method shall be provided for performing a final acceptance test by heating up the $\mathrm{MCO}$ to $75^{\circ} \mathrm{C}\left(167^{\circ} \mathrm{F}\right)$ and measuring the gas generation rate. The acceptance criterion is $1.4 \mathrm{kPa}\left(0.2 \mathrm{lbf} / \mathrm{in}^{2}\right)$ per hour or less in total pressurization rate averaged over a 12 -hour period.

c. A method shall be provided to cool the cask-MCO to $15^{\circ} \mathrm{C}\left(59^{\circ} \mathrm{F}\right)$ or lower at the conclusion of the drying cycle and final acceptance tests.

d. A method shall be provided to drain and dry the cooling water from the cask cavity (this defines the start of the transportation window to the CSB). 
e. A method shall be provided to backfill the MCO with industrial-grade helium at $115 \mathrm{kPa} \pm 7 \mathrm{kPa}\left(16.7 \pm 1 \mathrm{lbf} / \mathrm{in}^{2}\right)$. The added helium purity specification is $99.9 \%$.

f. A method shall be provided for reinstalling the cask lid before shipping to the CSB.

g. A method shall be provided for backfilling the cask- $\mathrm{MCO}$ annular region with industrial-grade helium to an absolute pressure of $115 \mathrm{kPa} \pm 7 \mathrm{kPa}\left(16.7 \pm 1 \mathrm{lbf} / \mathrm{in}^{2}\right)$.

\subsubsection{Process Vents and Exhausts}

a. The CVDF shall provide a method to prevent truck emissions from entering the CVDF.

b. The process offgas system shall provide ventilation through a process hood for contamination control at the top of the $\mathrm{MCO}$ before process connection during the drying cycle and acceptance tests, and before process disconnect and MCO inerting and sealing.

c. The process offgas system shall provide ventilation from all piping and equipment vent paths that may be contaminated.

\subsubsection{Cold Vacuum Drying Facility Requirements}

a. The CVDF shall provide protection from the design basis environmental conditions (see Chapter 3.0) for the process and utility systems contained within the CVDF and for the facility workers. The CVDF shall protect the environment and collocated and facility workers from process hazards.

b. A radiation monitoring system shall be provided.

c. A communications/Hanford Local Area Network (HLAN) system shall be provided.

d. A compressed air/instrument air system shall be provided.

e. A helium system shall be provided.

f. Cranes, hoists, and seismic restraints shall be provided.

g. Condensate and drainage systems shall be provided.

h. An electrical power distribution/lighting system shall be provided.

i. A service water system shall be provided. 
j. A fire protection and detection system shall be provided.

k. A deionized water system shall be provided.

1. A potable water system shall be provided.

m. A sewage collection system shall be provided.

n. An HVAC system shall be provided.

o. A reference air system shall be provided.

p. A contaminated water sampling and analysis system shall be provided.

q. A radioactive effluent handling and disposal system shall be provided.

r. A tempered water cooling system shall be provided.

s. A chilled water system shall be provided.

t. A vacuum purging system (VPS) chilled water system shall be provided.

u. An environmental (stack) monitoring system shall be provided.

v. A security system shall be provided.

\subsubsection{Process Conditions of Operation}

This section specifies the normal and off-normal thermal and hydraulic transients in the cask-MCO related heating and cooling systems and the vacuum drying system that will be considered in the evaluation and analyses of the structural design of the systems and components of the CVDF. This section does not include events related to any component testing.

The conditions of operation are based on both steady state and transient events. These events are the result of the following:

a. Functional testing prior to SNF loading and drying operation

b. Testing to characterize the design

c. Simulation of anticipated transients

d. Potential failures in the cask-MCO and CVDF systems 
e. Past experience and previous analysis of conditions of operations conducted for the Fast Flux Test Facility, Clinch River Breeder Reactor Plant, and for the systems support of DOE's Large Component Development Program.

The descriptions of these conditions of operations are based on available engineering analysis and current system understanding. As design of the K Basin SNF CVDF is completed, the descriptions of these conditions of operations will be updated. The selected conditions of operations describe conditions that may occur during plant operation and that are sufficiently severe or frequent to be of significance to the structural behavior of components. The frequency of occurrence is for use in component stress analysis and does not necessarily represent actual plant operation. The transient analysis of these events, when used as a basis for component structural design, will provide confidence that the component is appropriate for its application over the design life of the $\mathrm{K}$ Basin SNF CVDF.

Systems and components classified as safety class or safety significant and designated as PC-3 (see Section 3.4.7) are designed to meet the intent of the ASME Boiler and Pressure Vessel Code (ASME Code), Section VIII, and ANSU/ASME B31.3-1993, Plant and Petroleum Refinery Piping. To be consistent with this approach, CVDF duty cycle events are described in terms of ASME Code, Section III loading categories, namely, Levels A (normal operation), B (upset condition), C (emergency condition) and D (faulted condition). (See also McCormick [1981] for application of the four levels of operation.) The intent of these service loading categories is applicable to the CVDF and components. For other intended design basis criteria such as the ASME Code, Section VII, and ANSI/ASME B31.3-1993, it is the responsibility of the designer to select appropriate design conditions and load combinations based on the conditions of operations presented here. Alternative criteria development for application of Level D-type loading conditions to the ASME Code, Section VIII, and ANSI B31.3-1993 is the responsibility of the system-component designer.

CVDF testing and operation is expected to last up to 2.5 years. All equipment shall be designed for a minimum of 3 years, and if possible without significant cost, up to 5 years of lifetime including pre-operational testing, normal operation, and postoperational removal or storage. Redundant systems and replaceable components shall be provided as necessary to achieve this lifetime. Individual system design shall provide the required reliability to meet operational performance goals. The term "frequency" specified for each conditions of operations throughout this section means the design frequency of that event. Refer to Table 2-1 for a definition of system operating states versus typical temperatures.

The CVDF serves both $\mathrm{K}$ West Basin and $\mathrm{K}$ East Basin MCO shipments. The process, facility, and equipment are described in the WHC-SD-SNF-RPT-010. The process flow diagram is depicted on drawing $\mathrm{H}-1-81166$. 
Table 2-1. Definition of States.

\begin{tabular}{|l|l|l|l|l|l|l|}
\hline \multicolumn{1}{|c|}{ State variable } & \multicolumn{1}{|c|}{$\begin{array}{c}\text { Cold } \\
\text { standby }\end{array}$} & $\begin{array}{c}\text { Bulk water } \\
\text { drain }\end{array}$ & $\begin{array}{c}\text { Vacuum } \\
\text { pump down } \\
\text { and purge }\end{array}$ & Hot standby & $\begin{array}{c}\text { Post dry hot } \\
\text { monitoring }\end{array}$ & $\begin{array}{c}\text { Dry cold } \\
\text { standby }\end{array}$ \\
\hline $\begin{array}{l}\text { MCO vessel } \\
\text { temperature }\left({ }^{\circ} \mathrm{C}\right)\end{array}$ & 15 & 50 & 50 & 50 & 75 & 15 \\
\hline MCO pressure (torr) & 900 & 900 & $0.5-900$ & 900 & 900 & 900 \\
\hline
\end{tabular}

The conditions of operations descriptions presented in this section contain many events. Some of these events are planned, some others are part of the test program, and the other events are unplanned. Some of the events include an emergency shutdown. However, quantitative values for the trip parameters have not yet been selected. A tentative set will be used for the design thermal report and reported therein. When these parameters are developed, they will be included in the final design report document, as well as in the final design thermal report.

2.2.10.1 Normal Conditions of Operations (Level A). The ASME Code, Section III, defines Level A service limits as those sets of limits that must be satisfied for all Level A service loadings identified in the design specifications to which the component or support may be subjected in the performance of its specified service function. These limits are referred to as normal conditions, which are defined as "any conditions in the course of system startup, hot standby, operation in the design power range and system shutdown, other than upset, emergency, faulted conditions" to which the component is subjected. Level $A$ conditions are also termed operationally safe conditions. These Level $\mathrm{A}$ events include the planned test and operation program. Detailed Level A descriptions can be found in Appendix D.

2.2.10.2 Upset Conditions of Operations (Level B). The ASME Code defines Level B service limits as those sets of limits that must be satisfied for all Level B service loadings identified in the design specifications for which these service limits are designated. The component or support must withstand these loadings without damage requiring repair. These limits are referred to as upset conditions, which are defined as "any deviation from normal conditions anticipated to occur often enough that design should include a capability to withstand the conditions without operational impairment." The upset conditions include those transients that result from any single operator error or control malfunction, transients caused by a fault in a system component requiring its isolation from the system, and transients due to loss of load or power. Level $B$ service conditions include any abnormal incidents not resulting in a forced outage and also forced outages for which the corrective action does not include any repair of mechanical damage. Level B conditions may degrade a system to some extent but will not cause major system damage or injury to personnel. The system may be returned to service after appropriate recovery procedures are implemented. The estimated frequency of service Level B conditions is included in the detailed Level B event descriptions found in Appendix D. 
2.2.10.3 Emergency Conditions of Operations (Level C). The ASME Code defines Level C service limits as those sets of limits that must be satisfied for all Level $\mathrm{C}$ service loadings identified in the design specifications for which these service limits are designated. These sets of limits permit large deformations in areas of structural discontinuity. The occurrence of Level C stress limits may necessitate the removal of the component from service for inspection or repair of damage to the component or supports. These conditions are referred to as emergency conditions, which are defined as "those deviations for normal conditions which require shutdown for correction of the condition or repair of damage in the system." Level C events may cause personnel injury and, if immediate action is not taken, serious injuries or deaths and/or loss of the system. The conditions have a low probability of occurrence but are included to provide assurance that no gross loss of structural integrity will result as a concomitant effect of any damage developed in the system.

Since the individual emergency events are not expected to occur during the plant operating life, the number of event occurrences specified as a design basis are based on conservative judgement and acceptable plant investment risk. Detailed Level $\mathrm{C}$ event descriptions can be found in Appendix D.

2.2.10.4 Faulted Conditions of Operations (Level D). The ASME Code defines Level D service limits as those sets of limits that must be satisfied for all Level D service loadings identified in the design specifications for which these service limits are designated. These sets of limits permit gross general deformation with some consequential loss of dimensional stability and damage requiring repair, which may require removal of the component from service. These conditions are referred to as faulted conditions, which are defined as "those conditions or combinations of conditions associated with extremely low probability postulated events whose consequences are such that the integrity and operability of the system may be impaired to the extent that considerations of public health and safety are involved. Failure may cause severe system degradation, possibly causing loss of system and/or multiple deaths or injuries. Such considerations require compliance with safety criteria as may be specified by jurisdictional authorities." Unless otherwise noted, the cask-MCO or vacuum drying process bay will not be returned to service following a Level D event.

None of these events are expected to occur during the 2-year plant operating design life. However, each safety-class system or component must be designed to functionally perform during any single worst-case Level $D$ event and maintain its safety function. The effects of high temperature metal melt-through must be included in the component evaluations as appropriate. Detailed Level D event descriptions can be found in Appendix D.

\subsection{INTERFACES}

The cold vacuum drying process shall remove free water and some waters of hydration (principally uranium hydrate) from MCOs that have been loaded with SNF at the K Basins. The MCOs shall be received at the CVDF flooded with water in a sealed cask that is moved on a truck-trailer transporter. 


\subsubsection{Multicanister Overpack Interfaces}

2.3.1.1 Multicanister Overpack Configuration. The MCO provides primary containment for the SNF during transfer, fuel drying, conditioning, and interim storage. The MCO is a vertical, cylindrical stainless steel container that retains the spent fuel. The overall dimensions of the MCO are $610 \mathrm{~mm}$ ( $24 \mathrm{in}$.) in diameter by $4,064 \mathrm{~mm}$ (160 in.) tall. The wall thickness is $13 \mathrm{~mm}(0.5 \mathrm{in}$.). The shell is welded to a stainless steel bottom forging $610 \mathrm{~mm}(24 \mathrm{in}$.) in diameter. The bottom forging is $45 \mathrm{~mm}$ (1.76 in.) thick with a center area $22 \mathrm{~mm}$ (0.88 in.) thick, forming a 22-mm(0.88-in.-) deep pocket that minimizes residual water after draining. A 305-mm- (12-in.-) thick shield plug is inserted into the top of the MCO. The MCO top shield plug is connected to the MCO shell by a threaded assembly called the locking and lifting ring. The locking and lifting ring is threaded on the outside, mating with threads on the interior of the MCO. The locking and lifting ring compresses the MCO mechanical seal. The top of the shield plug has four penetrations (the vent and drain ports connect to two plug actuators/connector assemblies)-the long process tube, the short process tube, a rupture disk, and a relief valve downstream from a HEPA filter. For shielding purposes, all four penetrations have double bends as they penetrate the shield plug (HNE-SD-TP-SARP-017). The MCO vent and drain ports will be equipped with valves (threaded plugs with metallic seals) to accommodate connection with the CVDF system.

The MCO with SNE is depicted on the following drawings:

MULTI-CANISTER OVERPACK ASSEMBLY

MCO MECHANICAL CLOSURE

MCO MECHANICAL CLOSURE SHIELD PLUG

MCO PROCESS VALVES

K-BASIN SNF STORAGE BASKET MARK IA

K-BASIN SNF SCRAP BASKET MARK 1A

MCO MARK IV SNF STORAGE BASKET

MCO MARK IV SNF SCRAP BASKET
H-2-828041

H-2-828042

$\mathrm{H}-2-828045$

$\mathrm{H}-2-828047$

$\mathrm{H}-2-828060$

$\mathrm{H}-2-828065$

$\mathrm{H}-2-828070$

$\mathrm{H}-2-828075$

Table 2-2 lists the pertinent MCO configuration and content requirements.

2.3.1.2 Multicanister Overpack Connections. Figure 2-4 provides a sketch of the cask-MCO configuration upon receipt at the CVDF. The cask and $\mathrm{MCO}$ are flooded with water, except from a small gas space at the top of both vessels. The cask is transferred from the basins to the CVDF in a sealed configuration. However, the $\mathrm{MCO}$ is vented via a filtered vent port to the cask cavity (port 2, short draw tube, shown on Figure 2-4), allowing any gases that may develop from uranium corrosion reactions during transfer to equalize between the MCO and cask. The MCO safety rupture disk, port 4 , is also active on receipt at the CVDF. The other MCO ports are deactivated by the installation of port covers over closed block valves (i.e., process relief and long process (drain) port seal covers in place, ports 1 and 3 respectively). 
Table 2-2. Multicanister Overpack Configuration and Content Description. (2 sheets)

\begin{tabular}{|c|c|c|}
\hline Parameter or design data & Units & Specified design rating \\
\hline Internal design pressure & $\mathrm{kPa}$ (gauge)(psig) & $1,034(150)$ \\
\hline MCO operating vacuum pressure & $\mathrm{Pa}$ (torr) & $66.6(.5)$ \\
\hline $\begin{array}{l}\text { Surface areas (geometric) } \\
\text { - } \mathrm{MCO} \\
\text { - Fuel elements }\end{array}$ & $\mathrm{m}^{2}\left(\mathrm{ft}^{2}\right)$ & $\begin{array}{c}7.71(83) \\
85.28(918)\end{array}$ \\
\hline Design maximum MCO temperature at the CVDF & ${ }^{\circ} \mathrm{C}\left({ }^{\circ} \mathrm{F}\right)$ & $85(185)$ \\
\hline Operating maximum $\mathrm{MCO}$ temperature at the CVDF & ${ }^{\circ} \mathrm{C}\left({ }^{\circ} \mathrm{F}\right)$ & $75(167)$ \\
\hline $\begin{array}{l}\text { SNF decay heat per MCO, } \\
\text { - Average } \\
\text { - Maximum }\end{array}$ & Watts & $\begin{array}{l}400 \\
835\end{array}$ \\
\hline $\begin{array}{l}\text { Weight of empty MCO with Mark IV fuel storage } \\
\text { baskets (stainless steel) }\end{array}$ & $\mathrm{kg}(\mathrm{lb})$ & $2,111(4,654)$ \\
\hline $\begin{array}{l}\text { Weight of empty MCO with Mark } 1 \text { A fuel storage } \\
\text { baskets (stainless steel) }\end{array}$ & $\mathrm{kg}(\mathrm{lb})$ & $2,762(6,090)$ \\
\hline $\begin{array}{l}\text { Weight of fuel elements with Mark IV fuel, } \\
\text { - Uranium } \\
\text { - Cladding }\end{array}$ & $\mathrm{kg}(\mathrm{lb})$ & $\begin{array}{c}6,345(13,988) \\
443(977)\end{array}$ \\
\hline $\begin{array}{l}\text { Weight of fuel elements with Mark IA fuel, } \\
\text { - Uranium } \\
\text { - Cladding }\end{array}$ & $\mathrm{kg}(\mathrm{lb})$ & $\begin{array}{c}4,781(10,540) \\
409(902)\end{array}$ \\
\hline Weight of nominal SNF corrosion product & $\mathrm{kg}(\mathrm{lb})$ & $12(26)$ \\
\hline $\begin{array}{l}\text { Initial free water content } \\
\text { - Upon receipt } \\
\text { - Following bulk water drain }\end{array}$ & $L\left(\mathrm{ft}^{3}\right)$ & $\begin{array}{c}476-529(16.8-18.7) \\
5-32(0.18-1.13)\end{array}$ \\
\hline $\begin{array}{l}\text { Gas void volume } \\
\text { - Upon receipt } \\
\text { - After drying }\end{array}$ & $I\left(\mathrm{ft}^{3}\right)$ & $\begin{array}{c}21(0.74) \\
497-550(17.6-19.4)\end{array}$ \\
\hline $\begin{array}{l}\text { Hydrogen generation rate } \\
\text { - Safety basis } \\
\text { - Nominal }\end{array}$ & $\mathrm{g} / \mathrm{min}$ & $\begin{array}{l}2.4 \times 10^{-2} \\
\text { TBD }\end{array}$ \\
\hline MCO fuel fission gas release rate ${ }^{2}$ & Cilyr & 29 \\
\hline MCO particulate release ${ }^{b}$ & grams & 42.6 \\
\hline $\begin{array}{l}\text { MCO retained fuel particulate } \\
\text { - UO4-4H2O } \\
\text { - UO4-2H2O } \\
\text { - UO2 } \\
\text { - UH3 } \\
\text { - Chemisorbed water } \\
\text { Total particulate }\end{array}$ & $\mathrm{kg}$ & $\begin{array}{c}12-145 \\
0 \\
0 \\
\text { TBD } \\
0.04-0.4 \\
12-145\end{array}$ \\
\hline MCO particulate size distribution ${ }^{d}$ & $\mu m$ & $1-10$ \\
\hline
\end{tabular}


Table 2-2. Multicanister Overpack Configuration and Content Description. (2 sheets)

\begin{tabular}{|l|c|c|}
\hline \multicolumn{1}{|c|}{ Parameter or design data } & Units & Specified design rating \\
\hline Initial MCO gas composition at CVDF receipt & & \\
$-\mathrm{H}_{2}$ & gmole & 0.91 \\
$-\mathrm{He}$ & & 1.85 \\
$-\mathrm{H}_{2} \mathrm{O}$ & & 0.03 \\
\hline
\end{tabular}

Note: The material in this table is from HNF-SD-SNF-DR-003, Multi-Canister Overpack Design Report, except as noted.

"Release rates are found in DOE/RL-96-47, U.S. Environmental Protection Agency Clean Air Act Notice of Construction for Spent Nuclear Fuel Project-Cold Vacuum Drying Facility, Project W-441.

Release per MCO drying operation into the bulk water from HNF-SD-W441-CN-001. Particulate shall be assumed to be fuel per WHC-SD-SNF-TI-009, 105-K Basin Material Design Basis Feed Description for Spent Nuclear Fuel Project Facilities. Also see Table 2-3 for an estimate of radionuclide inventory on a MCO basis.

Fuel particulate descriptions is from HINF-SD-SNF-TM-001.

${ }^{d}$ Size distribution is from HNF-SD-SNF-TM-001.

$\mathrm{CVDF}=$ Cold Vactum Drying Facility.

$\mathrm{MCO}=$ multicanister overpack.

SNF $=$ spent nuclear fuel.

$\mathrm{TBD}=$ to be determined. 
Figure 2-4. Cask-Multicanister Overpack Configuration upon Receipt at the Cold Vacuum Drying Facility.
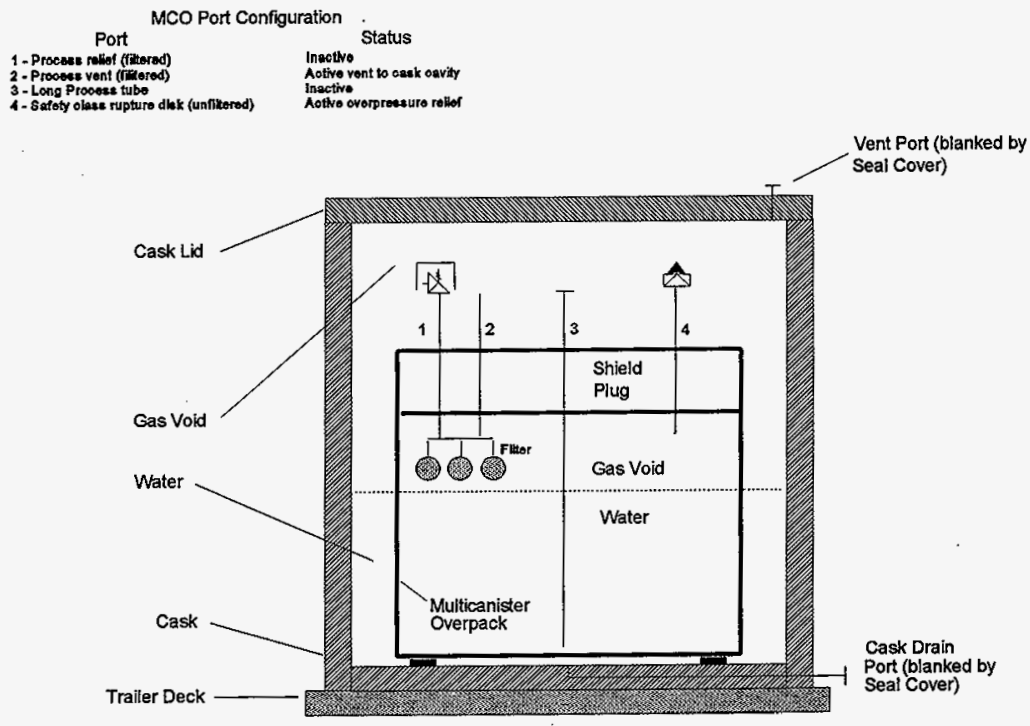
Table 2-3. Concentration of Radionuclides in Water Contained by a Multicanister Overpack.

\begin{tabular}{|c|c|c|c|c|c|}
\hline Isotope & $\begin{array}{l}\text { In water } \\
\text { inventory in an } \\
\text { average MCO } \\
\text { (Ci) }\end{array}$ & $\begin{array}{c}\text { Inventory in } \\
\text { water drained } \\
\text { from MCO } \\
4901 / \mathrm{MCO}(\mathrm{Ci} /)\end{array}$ & Isotope & $\begin{array}{l}\text { In water } \\
\text { inventory in an } \\
\text { average MCO } \\
\text { (Ci) }\end{array}$ & $\begin{array}{l}\text { Inventory in water } \\
\text { drained from } \\
\mathrm{MCO} 490 \mathrm{MCO} \\
\text { (Ci/l) }\end{array}$ \\
\hline $\mathrm{H}-3$ & $8.06 \mathrm{E}-04$ & $1.65 \mathrm{E}-06$ & Sn-121m & $1.75 \mathrm{E}-06$ & $3.58 \mathrm{E}-09$ \\
\hline$C-14$ & $1.53 \mathrm{E}-05$ & $3.11 \mathrm{E}-08$ & $\mathrm{Sn}-123$ & $3.83 \mathrm{E}-13$ & $7.82 \mathrm{E}-16$ \\
\hline Fe-55 & $4.05 \mathrm{E}-05$ & $8.26 \mathrm{E}-08$ & Sn-126 & $3.43 \mathrm{E}-06$ & $7.01 \mathrm{E}-09$ \\
\hline $\mathrm{Co}-60$ & $8.72 \mathrm{E}-05$ & $1.78 \mathrm{E}-07$ & Sb-124 & $6.67 \mathrm{E}-26$ & $1.36 \mathrm{E}-28$ \\
\hline $\mathrm{Ni}-59$ & $9.02 \mathrm{E}-07$ & 1.84 E-09 & $\mathrm{Sb}-125$ & 7.37 E-04 & $1.50 \mathrm{E}-06$ \\
\hline Ni-63 & $9.88 \mathrm{E}-05$ & $2.02 \mathrm{E}-07$ & Sb-126 & $4.80 \mathrm{E}-07$ & $9.79 \mathrm{E}-10$ \\
\hline Se-79 & $1.90 \mathrm{E}-06$ & $3.87 \mathrm{E}-09$ & $\mathrm{Sb}-126 \mathrm{~m}$ & $3.43 \mathrm{E}-06$ & $7.01 \mathrm{E}-09$ \\
\hline $\mathrm{K}_{\mathrm{r}-85}$ & $1.30 \mathrm{E}-02$ & $2.65 \mathrm{E}-05$ & $\mathrm{Te}-123 \mathrm{~m}$ & 6.07 E-19 & $1.24 \mathrm{E}-21$ \\
\hline Sr-90 & $2.22 \mathrm{E}-01$ & $4.54 E-04$ & $\mathrm{Te}-125 \mathrm{~m}$ & $1.80 \mathrm{E}-04$ & $3.67 \mathrm{E}-07$ \\
\hline Y-90 & $2.22 \mathrm{E}-01$ & $4.54 \mathrm{E}-04$ & $\mathrm{Te}-127$ & $2.09 \mathrm{E}-14$ & $4.26 \mathrm{E}-17$ \\
\hline$Y-91$ & $4.91 \mathrm{E}-22$ & $1.00 \mathrm{E}-24$ & $\mathrm{Te}-127 \mathrm{~m}$ & $2.13 \mathrm{E}-14$ & $4.35 \mathrm{E}-17$ \\
\hline Zr-93 & $8.81 \mathrm{E}-06$ & $1.80 \mathrm{E}-08$ & I-129 & $1.40 \mathrm{E}-07$ & $2.86 \mathrm{E}-10$ \\
\hline $\mathrm{Zr}-95$ & $3.71 \mathrm{E}-20$ & $7.57 \mathrm{E}-23$ & Cs-134 & $3.50 \mathrm{E}-04$ & $7.14 \mathrm{E}-07$ \\
\hline $\mathrm{Nb}-93 \mathrm{~m}$ & $5.44 \mathrm{E}-06$ & $1.11 \mathrm{E}-08$ & $\mathrm{Cs}-135$ & I.71 E-06 & $3.48 \mathrm{E}-09$ \\
\hline $\mathrm{Nb}-95$ & $8.22 \mathrm{E}-20$ & $1.68 \mathrm{E}-22$ & Cs-137 & 2.91 E-01 & $5.93 \mathrm{E}-04$ \\
\hline $\mathrm{Nb}-95 \mathrm{~m}$ & $2.76 \mathrm{E}-22$ & $5.62 \mathrm{E}-25$ & $\mathrm{Ba}-137 \mathrm{~m}$ & $2.75 \mathrm{E}-01$ & $5.61 \mathrm{E}-04$ \\
\hline Tc-99 & $6.34 \mathrm{E}-05$ & $1.29 \mathrm{E}-07$ & $\mathrm{Ce}-144$ & $2.01 \mathrm{E}-05$ & $4.11 \mathrm{E}-08$ \\
\hline $\mathrm{Ru}-106$ & $4.01 \mathrm{E}-05$ & 8.17 E-08 & $P_{T-144}$ & $1.99 \mathrm{E}-05$ & $4.06 \mathrm{E}-08$ \\
\hline Rh-106 & $4.01 \mathrm{E}-05$ & $8.17 \mathrm{E}-08$ & Pr-144m & $2.42 \mathrm{E}-07$ & $4.94 \mathrm{E}-10$ \\
\hline Pd-107 & $3.59 \mathrm{E}-07$ & $7.32 \mathrm{E}-10$ & Pm-147 & $1.02 \mathrm{E}-02$ & $2.08 \mathrm{E}-05$ \\
\hline $\mathrm{Ag}-110$ & $6.25 \mathrm{E}-12$ & $1.28 \mathrm{E}-14$ & $\mathrm{Sm}-151$ & $3.87 \mathrm{E}-03$ & $7.91 \mathrm{E}-06$ \\
\hline $\mathrm{Ag}-110 \mathrm{~m}$ & $4.71 \mathrm{E}-10$ & 9.61 E-13 & Eu-152 & $2.08 \mathrm{E}-05$ & $4.24 \mathrm{E}-08$ \\
\hline Cd-113m & $7.81 \mathrm{E}-05$ & $1.59 \mathrm{E}-07$ & Eu-154 & $2.36 \mathrm{E}-03$ & $4.81 \mathrm{E}-06$ \\
\hline In-113m & $4.71 \mathrm{E}-15$ & 9.61 E-18 & $\mathrm{Eu}-155$ & $4.86 \mathrm{E}-04$ & 9.93 E-07 \\
\hline Sn-113 & 4.71 E- 15 & $9.61 \mathrm{E}-18$ & Gd-153 & $2.82 \mathrm{E}-12$ & $5.75 \mathrm{E}-15$ \\
\hline $\mathrm{Sn}-119 \mathrm{~m}$ & $6.53 \mathrm{E}-09$ & $1.33 \mathrm{E}-11$ & Tb-160 & $6.10 \mathrm{E}-23$ & $1.24 \mathrm{E}-25$ \\
\hline \multicolumn{4}{|c|}{ Fission and activation product totals } & $1.04 \mathrm{E}+00$ & $2.13 \mathrm{E}-03$ \\
\hline $\mathrm{U}-234$ & $1.92 \mathrm{E}-05$ & $3.93 \mathrm{E}-08$ & $\mathrm{Pu}-241^{*}$ & $1.47 \mathrm{E}-01$ & $3.00 \mathrm{E}-04$ \\
\hline U-235 & $7.42 \mathrm{E}-07$ & $1.51 \mathrm{E}-09$ & $\mathrm{Pu}-242$ & $1.21 \mathrm{E}-06$ & 2.47 E-09 \\
\hline U-236 & $2.80 \mathrm{E}-06$ & $5.70 \mathrm{E}-09$ & Am-241 & $8.25 \mathrm{E}-03$ & $1.68 \mathrm{E}-05$ \\
\hline$U-238$ & $1.53 \mathrm{E}-05$ & $3.13 \mathrm{E}-08$ & Am-242 & $4.29 \mathrm{E}-06$ & 8.76 E-09 \\
\hline $\mathrm{Np}-237$ & $1.26 \mathrm{E}-06$ & $2.57 \mathrm{E}-09$ & Am-242m & $4.31 \mathrm{E}-06$ & 8.80 E-09 \\
\hline Pù-238 & $2.44 \mathrm{E}-03$ & $4.99 \mathrm{E}-06$ & Am-243 & $2.64 \mathrm{E}-06$ & $5.39 \mathrm{E}-09$ \\
\hline Pu-239 & $4.80 \mathrm{E}-03$ & $9.79 \mathrm{E}-06$ & $\mathrm{Cm}-242$ & $3.57 \mathrm{E}-06$ & $7.28 \mathrm{E}-09$ \\
\hline $\mathrm{Pu}-240$ & $2.62 \mathrm{E}-03$ & $5.34 \mathrm{E}-06$ & $\mathrm{Cm}-244$ & $3.17 \mathrm{E}-05$ & $6.47 \mathrm{E}-08$ \\
\hline \multicolumn{4}{|c|}{ Actinide totals } & $1.65 \mathrm{E}-01$ & $3.37 \mathrm{E}-04$ \\
\hline
\end{tabular}

Note: The material in this table is from HNF-SD-W441-CN-001. Does not include tritium from basin water.

*Plutonium-241 is not to be considered a TRU material and is not to be included in any TRU waste holding determination.

$\mathrm{MCO}=$ multicanister overpack.

TRU $=$ transuranic. 
a. The process drying system shall be capable of connecting to the MCO as described on drawing $\mathrm{H}-2-828045$ and $\mathrm{H}-2-828047$.

b. The process drying system shall be capable of accessing the MCO shielding plug interfaces by removing the MCO port covers as described on drawing H-2-828045.

c. The process drying system shall be capable of sealing the MCO after the cold vacuum drying operation is complete. The MCO ports shall be leak checked prior to installing the cask lid. The acceptance criterion for the leak check is that no observable bubble shall be exhibited following application of a bubble solution while the cask is pressurized with helium to a gauge pressure of $21 \mathrm{~Pa}\left(3 \mathrm{lbf} / \mathrm{in}^{2}\right)$.

d. Following acceptable leak checking the MCO port covers shall be installed on ports 2 (process vent/short process tube) and 3 (long process/drain tube); port covers shall be removed or verified to be removed from ports 1 (process relief/relief valve) and 4 (safety-class rupture disk).

\title{
2.3.2 Multicanister Overpack Cask and Transporter Interfaces
}

2.3.2.1 Multicanister Overpack Cask and Transporter Configuration. The cask and transporter are depicted on the following drawings that will appear in the vendors information file.

\author{
TN-WHC TRANSPORTATION SYSTEM ARRANGEMENT
}

TN-WHC TRANSPORTATION SYSTEM ASSEMBLY

TN-WHC CASK TRANSPORTATION SYSTEM ASSEMBLY AND PARTS LIST

\section{K BASIN TRANSPORT TRAILER WORK PLATFORM}

\section{K BASIN MCO/CASK CVD LID}

SNF is received at the CVDF packaged in an MCO which is transferred from either the $\mathrm{K}$ East or $\mathrm{K}$ West Basin in a cask loaded on a truck and trailer called the cask-MCO transporter. The MCO, containing fuel, remains in the cask and on the trailer throughout processing in the CVDF. The trailer is disconnected from the truck while processing activities are completed to minimize the inventory of flammable material in the CVDF (truck fuel tanks) and make efficient use of the truck vehicle.

The overall trailer length is $12.2 \mathrm{~m}(40 \mathrm{ft})$, overall width is $3.0 \mathrm{~m}(10 \mathrm{ft})$, and overall height with cask is $5,353 \mathrm{~mm}$ (17 ft, $6.75 \mathrm{in}$.). (Additional key feature descriptions, seismic restraints, access to cask lid, cask lid laydown, total weight, weight per tire, turning radius). The cask transportation assembly is shown on drawing $\mathrm{H}-1-81533$. The trailer has a work platform that is permanently attached to it. This work platform can be used.to work around the top of the cask 
and MCO while at the CVDF. The work platform is depicted on drawing H-1-81535 and H-1-81548.

The trailer will serve as a support mechanism for the cask-MCO during the vacuum drying process. The trailer will back into the CVDF and processing will proceed with the cask-MCO in a vertical position on the trailer. Movable platforms can be rolled over to service the cask and be pinned to the trailer and cask holder. The truck tractor shall leave prior to processing. Loading or unloading of the cask-MCO is avoided and no overhead crane will be required except to remove the cask top cover.

The trailer will have structural members and fastening devices that will allow the trailer to be secured to the concrete foundation at the CVDF. These additional structural restraints are to prevent loss of the safety function of the MCO during a design basis seismic event.

The cask is a vertical, cylindrical, stainless steel vessel. The cask has an outside diameter of $1,011 \mathrm{~mm}$ (39.81 in.) and height of 4,324 mm (170.25 in.). The overall packaging assembly, including the lifting device, has an outside diameter of $1,113 \mathrm{~mm}$ (43.83 in.) and overall height of $4,832 \mathrm{~mm}$ (190.25 in.). The cask has a cavity diameter of $640 \mathrm{~mm}(25.19 \mathrm{in}$.) and is $4,077 \mathrm{~mm}$ (160.5 in.) tall. The cask consists of a forged 186-mm- (7.31-in.-) thick, 4,324-mm- (170.25-in.-) long stainless steel cylinder with an integrally welded stainless steel bottom head that is $156 \mathrm{~mm}$ (6.13 in.) thick (HNF-SD-TP-SARP-017). The transport cask assembly is shown on drawing $\mathrm{H}-1-81535$.

The lid is a stainless steel forging with a $89-\mathrm{mm}-(3.5-\mathrm{in} .-)$ thick top and 76-mm (3-in.) sides, an outer diameter of $902 \mathrm{~mm}$ (35.5 in.), an inner diameter of $648 \mathrm{~mm}$ (25.5 in.), and a height of $279 \mathrm{~mm}$ (11 in.). The lid has a $102-\mathrm{mm}-(4-\mathrm{in.}-)$ tall, 106-mm- (4.16-in.-) wide flange at its base, which makes the diameter of the lid $1,011 \mathrm{~mm}$ (39.81 in.) at the flange. The base of the lid has a dove-tail groove that has its inner diameter $105 \mathrm{~mm}$ (4.12 in.) from the base exterior. The interior of the base of the lid also has a 55-mm- (2.16-in.-) wide, 28-mm- (1.09-in.-) tall notch that mates with a similar-sized extension in the cask shell. The lid is bolted to the cask body with 12,38-mm- (1.5-in.-) diameter bolts, which are arranged on a circle with a $926-\mathrm{mm}$ (36.44-in.) diameter. A single butyl rubber O-ring seal will form the containment boundary between the cask body and lid. Lid installation is guided by two alignment pins that are integral to the cask body (HNF-SD-TP-SARP-017). The transport cask lid assembly is shown on drawing H-1-85349.

Two lifting brackets are welded to the cask lid for lifting the cask and the lid. A 102-mm(4-in.-) diameter trunnion is welded to each lifting bracket. The brackets protrude $508 \mathrm{~mm}$ (20 in.) from the lid surface. Access to the MCO shielding plug interfaces for the vacuum drying process will be made by first removing the cask cover. The CVDF replaces the cover in preparation for transport of the cask-MCO to the CSB.

The cask arrives at the CVDF with a positive gas pressure as compared to atmospheric conditions. This condition is established at the basin prior to shipment by purging the head space of both the $\mathrm{MCO}$ and cask with helium during loading. The cask-MCO gas space is backfilled 
with helium to a gauge pressure of approximately $21 \mathrm{~Pa}\left(3 \mathrm{lbf} / \mathrm{in}^{2}\right)$ at the basin when the transfer is initiated. However, uranium corrosion reaction with water will generate hydrogen during the transfer while the cask is sealed.

The quantity of hydrogen generated during transfers depends on the surface area of uranium metal exposed to water in the $\mathrm{MCO}$, outside temperatures and solar radiant conditions during transfer, and the total time the cask is sealed. Thermal transient analysis for a series of bounding transport assumptions is presented in HNF-SD-TP-SARP-017. Based on results for a probable maximum MCO starting at $15^{\circ} \mathrm{C}\left(59^{\circ} \mathrm{F}\right)$, shipped during a hot day, and sealed for 8 hours during transfer, the gauge gas pressure within the cask is projected to be $83 \mathrm{kPa}\left(12 \mathrm{lbf} / \mathrm{in}^{2}\right)$. The gas pressure is projected to build to a gauge pressure of $379 \mathrm{kPa}\left(55 \mathrm{lbf} / \mathrm{in}^{2}\right)$ if the same $\mathrm{MCO}$ is sealed for 24 hours during transfer (a maximum transfer window of 24 hours is specified by HNF-SD-TP-SARP-017). The worst-case combination of conditions analyzed results in a gauge gas pressure of $655 \mathrm{kPa}\left(95 \mathrm{lbf} / \mathrm{in}^{2}\right)$ over a 24 -hour transfer window, which is projected to be the maximum pressure to be encountered in the CVDF receiving area.

The cask mass represents a significant thermal mass that must be considered in determining time periods required to heat or cool an MCO to a specified temperature. Therefore, the mass of key cask components from HNF-SD-TP-SARP-017 is summarized in Table 2-4.

Table 2-4. Mass of Cask Components.

\begin{tabular}{|l|c|}
\hline \multicolumn{1}{|c|}{ Cask component } & Mass, kg (lb) \\
\hline Cask shell (304L SS) & $15,590(34,370)$ \\
\hline Cask bottom (304L SS) & $1,032(2,275)$ \\
\hline Cask lid (304L SS) & $859(1,894)$ \\
\hline
\end{tabular}

Note: Information in this table is from page A2-5 of HNF-SD-TP-SART-017, Safety Analysis Report for Packaging (Onsite) Multicanister Overpack Cask, Rev. 0, Fluor Daniel Hanford, Incorporated, Richland, Washington.

The expected weights and centers of gravity of the MCO, MCO cask, contents, and ancillary equipment are summarized in Table 2-5. The total weight of the MCO cask with a $8,629-\mathrm{kg}(18,984-\mathrm{lb}) \mathrm{MCO}$ is $26,843 \mathrm{~kg}(59,054 \mathrm{lb})$ with the center of gravity located on the vertical centerline of the cask. Since the cask is nearly symmetrical, the center of gravity of the cask is near the geometrical center. The cask trailer and truck are assumed to weigh $20,412 \mathrm{~kg}$ $(45,000 \mathrm{lb})$. 
Table 2-5. Multicanister Overpack Cask and Multicanister Overpack Weights.

\begin{tabular}{|l|c|}
\hline \multicolumn{1}{|c|}{ Component } & $\begin{array}{c}\text { Weight } \\
\text { kg (lb) }\end{array}$ \\
\hline MCO sheil & $888(1,954)$ \\
\hline MCO shield plug & $557(1,226)$ \\
\hline Fuel baskets & $341(750)$ \\
\hline Water inside MCO & $2(4)$ \\
\hline Fuel & $6,841(15,050)$ \\
\hline Cask body & $17,173(37,780)$ \\
\hline Cask lid & $700(1,540)$ \\
\hline Lifting beam & $341(750)$ \\
\hline Trailer and truck & $20,412(45,000)$ \\
\hline Total & $47,627(105,000)$ \\
\hline
\end{tabular}

$\mathrm{MCO}=$ multicanister overpack.

The cask cavity external to the MCO vessel is received at the CVDF flooded with water. This water, while potentially contaminated during transfers from the basin, is assumed to be demineralized water. The volume of water received in the annular region is estimated from cask and MCO dimensions and corresponds to an initial mass of $120 \mathrm{~kg}$ ( $33.1 \mathrm{gal}$ ) water in the cask annular region upon receipt at the CVDF.

The expected radiation levels from the cask while at the CVDF are defined in WHC-SD-SNF-CAVR-001, Recent Dose Rate Calculational Summary for N-Reactor Fuel Handling and Shipping from $K$-Basin. The cask shielding evaluation supports the transport of N Reactor fuel from K Basin to the CSB in the MCO. The MCO shielding consists of shielding cask, cask lid, and MCO shield plug. A bounding source term consisting of $6.34 \mathrm{MTU}$ of Mark IV fuel was used as described in Chapter 2 of the Safety Analysis Report for Packaging (HNF-SD-TP-SARP-017).

The limits for this package are $1,000 \mathrm{mrem} / \mathrm{hr}$ at any point on the exterior surface of a package and $10 \mathrm{mrem} / \mathrm{hr}$ at a distance of $2 \mathrm{~m}(6.6 \mathrm{ft})$ from the package, and $2 \mathrm{mrem} / \mathrm{hr}$ at $6 \mathrm{~m}$ $(19.7 \mathrm{ft})$. After a hypothetical accident resulting in a loss of shielding, the limit as given in $10 \mathrm{CFR} 71.51$ is $1 \mathrm{rem} / \mathrm{hr}$ at $1 \mathrm{~m}(3.3 \mathrm{ft})$.

Three normal conditions were analyzed. In all normal conditions, the maximum dose rates were found to be at the bottom of the cask. The first normal transfer condition considers a wet 
MCO with cask lid removed. For a wet $\mathrm{MCO}$ with lid removed, the maximum dose rates are $1,640 \mathrm{mrem} / \mathrm{hr}$ at contact, $54 \mathrm{mrem} / \mathrm{hr}$ at $2 \mathrm{~m}(6.6 \mathrm{ft})$, and $7.3 \mathrm{mrem} / \mathrm{hr}$ at $6 \mathrm{~m}(19.7 \mathrm{ft})$. The second normal transfer condition considers a dry MCO with the cask lid in place. For a dry MCO with lid in place, the maximum dose rates are $1,800 \mathrm{mrem} / \mathrm{hr}$ at contact, $60 \mathrm{mrem} / \mathrm{hr}$ at $2 \mathrm{~m}$ $(6.6 \mathrm{ft})$, and $8.1 \mathrm{mrem} / \mathrm{hr} 6 \mathrm{~m}(19.7 \mathrm{ft})$. The third condition considered a dry MCO with the cask lid removed. The maximum dose rate at $1 \mathrm{~m}(3.3 \mathrm{ft})$ is $200 \mathrm{mrem} / \mathrm{hr}$.

The maximum total dose rates calculated for each condition at these distances are reported in Tables 2-6 and 2-7. Neutron dose rates were less than $10 \%$ of the corresponding photon dose rates. Dose rates for the third condition at $1 \mathrm{~m}(3.3 \mathrm{ft})$ are given in Table 2-8. The maximum dose rate at $1 \mathrm{~m}(3.3 \mathrm{ft})$ is $200 \mathrm{mrem} / \mathrm{hr}$.

Table 2-6. Dose Rates for a Wet Multicanister Overpack with Cask Lid Removed.

\begin{tabular}{|l|c|c|c|}
\hline \multirow{2}{*}{ Location relative to cask } & \multicolumn{3}{|c|}{ Dose rates in mrem/hr (MCNP uncertainty $\left.{ }^{*}\right)$} \\
\cline { 2 - 4 } & Contact & $2 \mathrm{~m}$ & $6 \mathrm{~m}$ \\
\hline Side & $48(2 \%)$ & $6.7(2 \%)$ & $1.4(2 \%)$ \\
\hline Top & $55(12 \%)$ & $1.3(5 \%)$ & $0.25(8 \%)$ \\
\hline Bottom & $1,640(2 \%)$ & $54(3 \%)$ & $7.3(9 \%)$ \\
\hline
\end{tabular}

"The one standard deviation statistical uncertainty (relative) in Monte Carlo calculation.

Table 2-7. Dose Rates for a Dry Multicanister Overpack with Cask Lid in Place.

\begin{tabular}{|l|c|c|c|}
\hline \multirow{2}{*}{ Location relative to cask } & \multicolumn{3}{|c|}{ Dose rates in mrem/hr (MCNP uncertainty) } \\
\cline { 2 - 4 } & Contact & $2 \mathrm{~m}$ & $6 \mathrm{~m}$ \\
\hline Side & $58(2 \%)$ & $8.5(1 \%)$ & $1.8(2 \%)$ \\
\hline Top & $8.2(15 \%)$ & $0.091(7 \%)$ & $0.011(17 \%)$ \\
\hline Bottom & $1,800(2 \%)$ & $60(3 \%)$ & $8.1(8 \%)$ \\
\hline
\end{tabular}

"The one standard deviation statistical uncertainty (relative) in Monte Carlo calculation. 
Table 2-8. Dose Rates for Accident Condition.

\begin{tabular}{|c|c|}
\hline Location relative to cask & $\begin{array}{c}\text { Dose rate } 1 \mathrm{~m} \text { from cask in mrem/hr (MCNP } \\
\text { uncertainty })\end{array}$ \\
\hline Side & $16(1 \%)$ \\
\hline Top & $11(5 \%)$ \\
\hline Bottom & $200(4 \%)$ \\
\hline
\end{tabular}

"The one standard deviation statistical uncertainty (relative) in Monte Carlo calculation.

After loading irradiated fuel assemblies, all MCO casks shall be surveyed prior to transport. out of the K Basins and the CVDF.

2.3.2.2 Cask and Transporter Connections. The cask, with lid installed, has two vent ports and one drain. The centers of the vent ports are located $127 \mathrm{~mm}(5 \mathrm{in}$.) from the exterior rim of the cask lid, while the drain port is positioned in the side of the cask body, $122 \mathrm{~mm}$ (4.79 in.) from the bottom. The drain port is closed with quick-disconnect couplings having an inside diameter of $16 \mathrm{~mm}(0.63 \mathrm{in}$.) The drain port is covered by a $152-\mathrm{mm}$ - (6-in.-) diameter, $19-\mathrm{mm}-(0.75$-in.-) thick cover that is bolted onto the cask with four $13-\mathrm{mm}(0.5$-in.) bolts. The vent ports are also closed with quick-disconnect couplings that have an inside diameter of $11 \mathrm{~mm}(0.44 \mathrm{in}$.). The vent ports are covered by $97-\mathrm{mm}-(3.81$-in.-) diameter, $19-\mathrm{mm}-(0.75$-in.-) thick covers that are bolted onto the lid with four $6-\mathrm{mm}(0.25$-in.) bolts. Each cover plate uses butyl rubber O-ring seals as the containment boundary (HNF-SD-TP-SARP-017). Leaktight containment $(0.1 \mathrm{~Pa}$ $\left[10^{-7} \mathrm{~atm} \mathrm{~cm} / \mathrm{s}\right]$, air) for the ports is provided by cover plates and butyl rubber $\mathrm{O}$-ring face seals. The cask ports are depicted on drawings H-1-81534 and H-1-81549.

The MCO cask closure lid uses a butyl rubber $\mathrm{O}$-ring face seal to maintain a leaktight $\left(0.1 \mathrm{~Pa}\left[10^{-7} \mathrm{~atm} \mathrm{~cm} / \mathrm{s}\right]\right.$, air) seal. The seal is located on the interface surface between the flange on the closure lid and the MCO cask shell. This seal is placed in an O-ring groove in the closure lid flange. The $\mathrm{O}$-ring will be compressed by tightening $1238-\mathrm{mm}(1.5-\mathrm{in}$.) bolts on the lid. The face seal is required to meet leaktight requirements upon initial loading of the cask and will undergo annual requalifications (not part of the CVDF subproject requirements).

2.3.2.3 Multicanister Overpack and Cask Annulus Seal Ring. A ring shall be provided by the CVDF project. The ring shall fit on the cask and be held in place with bolts using the bolt holes that are used for attaching the cask lid to the cask. The ring will include an inflatable seal system that retains water in the cask annulus while it is being circulated through the annulus with a maximum gauge pressure of $138 \mathrm{kPa}\left(20 \mathrm{lbf} / \mathrm{in}^{2}\right)$. The inflatable seal requires a source of instrument air at a gauge pressure of $310 \mathrm{kPa}\left(45 \mathrm{lbf} / \mathrm{in}^{2}\right)$ for inflation.

The interior of the seal ring will be open to allow process system connection access to the ports on the top of the MCO. The seal ring thickness shall be sized sufficiently to provide 
supplemental shielding for radiation streaming from the annulus. The cask-MCO seal ring is depicted on drawing $\mathrm{H}-1-83275$.

A piping connection will be provided for connecting to the cask annulus tempered water return.

2.3.2.4 Process Hood. A process hood shall be located on or near the top of the cask-MCO for localized contamination control. The process hood shall interface with the cask-MCO annulus seal ring as depicted on drawing $\mathrm{H}-1-83275$. The interior of the process hood shall be open to allow process system connection access to the ports on the top of the MCO.

2.3.2.5 Tempered Water System. A TWS shall be provided that will allow the circulation of temperature-controlled water through the cask annulus. The TWS will control the temperature of the MCO outer wall in the range of $15^{\circ} \mathrm{C}$ to $75^{\circ} \mathrm{C}\left(59^{\circ} \mathrm{F}\right.$ to $\left.167^{\circ} \mathrm{F}\right)$. The TWS supply shall connect to the cask lower drain port quick disconnect. The TWS return shall connect to the cask-MCO seal ring port quick disconnect.

2.3.2.6 Helium Supply. A supply of pressurized helium shall be provided to perform a final inerting and pressurization of the cask annulus. Helium at a gauge pressure of $21 \mathrm{kPa}\left(3 \mathrm{lbf} / \mathrm{in}^{2}\right)$ shall be introduced into the cask annulus following final TWS drain and prior to shipment of the cask-MCO to the CSB following the cold vacuum drying process. Helium filling the cask annulus shall be industrial grade purity.

\subsubsection{K Area Facility Interfaces}

The CVDF is to be located near the west boundary of the $100 \mathrm{~K}$ Area, west of the $165-\mathrm{KW}$ Power Control Building. Routine and emergency vehicle access to the facility is provided by the main gate to the $100 \mathrm{~K}$ Area. This site was selected for the following reasons:

- Gradually sloped contours that minimize grading requirements

- Close proximity to all required utilities

- Within the existing security boundary of the $100 \mathrm{~K}$ Area

- Minimal interference with underground structures existing at the time of construction.

The facility is situated to provide a flat, level surface at the transport access doors with the building slab at grade to the south and above grade to the north. The final site grading provides drainage to the north and no piping of storm water is provided. A parking area for maintenance vehicles is to be provided outside the building along with a large asphalt area as a cask transport turnaround.

2.3.3.1 Interfaces for Electrical Utilities. Normal building electrical power is to be provided from the $13.8 \mathrm{kV}$ overhead power lines that come to the north edge of the site perimeter. The main power supply is converted from overhead lines to an underground circuit at the CVDF site boundary to supply a transformer located outside the facility. The underground primary conduit 


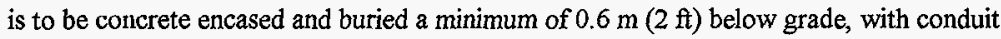
marking tape buried approximately $0.3 \mathrm{~m}(1 \mathrm{ft})$ below grade.

Power shall be routed from the outside transformer into the building through underground conduits and distributed by a free-standing, metal-enclosed switchboard to be located in an electrical and telecommunication room. Panelboards for power distribution, receptacles, and small loads are to be constructed with Federal Specification W-P-115, Type 1, Class 1.

\subsubsection{Interfaces for Piped System Utilities.}

2.3.3.2.1 Service Water. Service water (filtered river water) is supplied to the CVDF from the $100 \mathrm{~K}$ Area fire protection system. The fire protection line is an underground 8-in. PVC pipe originating on the west side of $165-\mathrm{KW}$ and will form a loop around the CVDF building. Fire hydrants are to be located at the northwest and southeast corners of the facility site. A 6-in. building service line shall enter the east side of the CVDF building supplying the building fire sprinkler system and a separate line shall feed input to the deionized water system.

2.3.3.2.2 Potable Water. Potable water is supplied to the CVDF from the $100 \mathrm{~K}$ Area sanitary water loop located in the KW support tunnel. The water service main is an underground 2-in. copper pipe originating from the west side of $165-\mathrm{KW}$ and entering the east side of the administrative area. Backflow preventers and pressure reducing valves are to be located inside the CVDF.

\subsubsection{Communications.}

2.3.3.3.1 Security. The security-monitoring system shall interface with the $100 \mathrm{~K}$ Area security system.

2.3.3.3.2 Phones. The Hanford Site phone system shall be extended to the CVDF.

2.3.3.3.3 Hanford Local Area Network. HLAN shall be extended to the CVDF.

\subsection{REFERENCES}

10 CFR 71, "Packaging and Transportation of Radioactive Material," Code of Federal Regulations, as amended.

ANSI B31.3-1993, 1993, Chemical Plant and Petroleum Refinery Piping, American Society of Mechanical Engineers, New York, New York.

ASME Code, 1995, Boiler and Pressure Vessel Code, American Society of Mechanical Engineers, New York, New York. 
DOE/RL-96-47, 1996, U.S. Environmental Protection Agency Clean Air Act Notice of Construction for Spent Nuclear Fuel Project--Cold Vacuum Drying Facility, Project W-441, U.S. Department of Energy, Richland Operations Office, Richland, Washington.

Federal Specification W-P-115

HNF-SD-SNF-DR-003, 1997, Multi-Canister Overpack Design Report, Rev. 0, Fluor Daniel Hanford, Incorporated, Richland, Washington.

HNF-SD-SNF-TM-001, 1997, Flowsheet Description for the Cold Vacuum Drying Facility Supporting the Spent Nuclear Fuel Project, Rev 0, Fluor Daniels Hanford, Incorporated, Richland, Washington.

HNF-SD-TP-SARP-017, 1997, Safety Analysis Report for Packaging (Onsite) Multicanister Overpack Cask, Rev. 0, Fluor Daniel Hanford, Incorporated, Richland, Washington.

HNF-SD-W441-CN-001, 1997, Radionuclide Inventory of BulkMCO Water at Cold Vacuum Drying Facility, Rev.0, Fluor Daniel Hanford, Incorporated, Richland, Washington.

McCormick, N. J., 1981, Reliability and Risk Analysis Methods and Nuclear Power Applications, Academic Press.

WHC-SD-SNF-CAVR-001, 1996, Recent Dose Rate Calculational Summary for N-Reactor Fuel Handling and Shipping from K-Basin, Rev. 0, Westinghouse Hanford Company, Richland, Washington.

WHC-SD-SNF-RPT-010, 1996, Spent Nuclear Fuel Project Operational Description, Rev. 0, Westinghouse Hanford Company, Richland, Washington.

WHC-SD-SNF-TI-009, 1995, 105-K Basin Material Design Basis Feed Description for Spent Nuclear Fuel Project Facilities, Rev. 0, Westinghouse Hanford Company, Richland, Washington.

Drawings:

H-1-81166, CVD Process Flow Diagram

H-1-81533, TN-WHC Transportation System Arrangement

H-1-81534, TN-WHC Transportation System Assembly

H-1-81535, TN-WHC Cask Transportation System Assembly and Parts List

H-1-81548, K Basin Transport Trailer Work Platform 
H-1-81549, K Basin MCO/Cask CVD Lid

H-1-83275

H-2-828041, Multi-Canister Overpack Assembly

H-2-828042, MCO Canister Detail

H-2-828045, MCO Mechanical Closure Shield Plug

H-2-828047, MCO Process Valves

H-2-828060, K-Basin SNF Storage Basket Mark 1A

H-2-828065, K-Basin SNF Scrap Basket Mark IA

H-2-828070, MCO Mark IV SNF Storage Basket

H-2-828075, MCO Mark IV SNF Scrap Basket 
HNF-SD-SNF-DRD-002 REV 1

This page intentionally left blank. 


\subsection{SAFETY FUNCTIONAL REQUIREMENTS}

\subsection{SCOPE AND OBJECTIVES}

\subsubsection{Objectives}

The safety of the public and the worker, and the protection of the environment shall be the primary considerations in the design, construction, startup, and operation of the CVDF. The CVDF design includes the means to protect the public, worker, and equipment from any hazards associated with the operation of the facility. The design and operation shall maintain the CVDF within its safety authorization basis and shall be in full compliance with applicable federal, state, and local laws and regulations. Operations shall be designed to be conducted efficiently. Exposures to radiation and toxic materials shall be held ALARA consistent with good industry practice and DOE orders. No lost-time accidents shall be a primary goal.

\subsubsection{Scope}

The scope of the safety requirements for CVDF is determined by the hazards associated with the operation of the facility. WHC-SD-SNF-PSE-003, Preliminary Safety Evaluation for the Spent Nuclear Fuel Project's Cold Vacuum Drying Facility, has been completed. Hazards were identified and ranked according to frequency of occurrence and potential consequences. Some hazards, which are classified as common industrial hazards, are not considered specifically in the hazards assessment but taken care of by common engineering and design safety practices. Therefore, common industrial hazards are not covered with specific safety requirements. The CVDF design will include features that ensure capability of compliance with Occupational Safety and Health Administration regulations during construction and operation. Hazards identified with credible potential accident consequences above the DOE SNF Project recommended risk guidelines (Sellers 1996) are required to be mitigated with engineered design and operating features.

The design of the CVDF shall specifically address protection of the public, operations personnel, and environment by means of engineered safety systems, environmental monitoring systems, and safety assessment of the design and proposed operations. Public and environmental safety assessments shall include analysis of both normal operational conditions and postulated off-normal/accident scenarios. This will be accomplished by applying technical requirements of applicable federal and state statutes, DOE orders and regulations, and specific NRC equivalency requirements deemed applicable to the CVDF. Other design guidance documents designated as "Applicable Documents" in Section 2.0 of HNF-S-0435, Performance Specification for the $K$ Basin SNF Cold Vacuum Drying Facility Low Temperature Vacuum Drying Module, will be used as general reference and background documents except where specifically required by DOE order, formal CVDF Project Management direction, or as called out in other sections of this DRD. 


\subsection{GENERAL REQUIREMENTS}

\subsubsection{Facility Hazards}

The Preliminary Safety Evaluation (PSE) for SNF Project CVDF (WHC-SD-SNF-PSE-003) provides a preliminary hazard analysis and DBAs. The facility is categorized as a Hazard Category 2 facility in accordance with DOE-STD-1027-92, Hazard Categorization and Accident Analysis Techniques for Compliance with DOE Order 5480.23, Nuclear Safety Analysis Reports. Design basis events (accidents) are defined further in Section 3.5.2.

Facility hazards were identified in a preliminary hazards assessment documented in the PSE (WHC-SD-SNF-PSE-003). The preliminary hazards assessment in the PSE identified nuclear, nonnuclear, natural phenomena, and worker safety hazards. These hazards are grouped into the above categories and listed below.

Nuclear Hazards

- Contamination - Contamination and exposure from radioactive isotopes released from the spent fuel in the form of contaminated gases, liquids or solids (particulates)

- Direct Radiation - Exposure from radiation field created by the spent fuel

- Criticality - Inadvertent nuclear criticality event

Nonnuclear Hazards

- Thermal Reaction - A fuel corrosion reaction in the MCO creating heat and escalating into fuel ignition and burn

- Explosion - Deflagration or detonation in the MCO from hydrogen gas produced from the fuel corrosion reaction

- Fire - A facility fire causing damage to structures, systems or components

- Loss of Support Utilities and/or Control Functions - Loss of support utilities and/or control functions to the facility and process causing upset conditions that may lead to accidents involving other facility hazards

Natural Phenomena Hazards

- Seismic - Seismic event causing structural or equipment failure

- Tornado Winds and High Winds - Winds causing structural or equipment failure

- Floods - Flood waters causing structural or equipment failure

- Volcanic Ash - Fallout of volcanic ash causing structural or equipment failure 
(Note: Snow loads and lightning are covered under structural loads and electrical systems.)

\section{Worker Safety Hazards}

- Process Hazards - Process hazards leading to multiple severe worker injuries or worker fatality.

- Common Industrial Hazards - Industrial hazards from the operation of common industrial systems and equipment (e.g., electrical shock, noise, working at heights).

\subsubsection{Application of U.S. Department of Energy Orders and Statutes to Hazards}

The hazards listed above are regulated by DOE orders and federal statutes. In addition, NRC equivalency requirements have been identified and are also applied to CVDF the same as DOE orders and federal statutes. The applicable DOE orders, federal statutes, and NRC equivalency requirements are listed from Section 1.4.2, Table 1-2. Table 3-1 lists the requirements sources that contain applicable requirements for each of the types of hazards. Codes and standards specific to the various design areas (e.g., Mechanical, Architectural, Structural, HVAC) are given in the design requirements sections of this DRD.

\subsection{PROJECT SAFETY ANALYSES}

The interpretation and application of the safety requirements require safety analyses to be performed to characterize the potential effects or consequences from the identified hazards. Table 3-2 lists the safety analyses performed to characterize the hazards listed in Table 3-1. The safety bases and safety design requirements results from each analysis are summarized in Table 3-3. These results, as fully defined in these reference analyses, shall be the safety bases for the safety design requirements.

The assumptions, results, and safety bases of safety analyses performed for the CVDF shall be incorporated into the facility's design documentation through formal assignment of all SSCs to safety classifications according to criteria based on the potential consequences of a failure. This assignment of a safety classification shall be performed in compliance with the requirements of WHC-CM-4-46, Safety Analysis Manual, Chapter 9.0, "Safety Structures, Systems, and Components," Revision 2, Change 1. The safety classification categories are designated safety class, safety significant, and general service, which represents all non-safety SSCs. The safety classification of SSCs will be appropriately reflected in equipment specifications, system descriptions, operating instructions, test procedures, and other design media (approved for construction drawings). Safety-class and safety-significant items shall be identified wherever they are depicted or listed in design documentation. 
Table 3-1. Safety Requirements Versus Hazards.

\begin{tabular}{|c|c|c|c|c|c|c|c|c|c|c|c|c|}
\hline \multirow[b]{2}{*}{ Requirements sources } & \multicolumn{3}{|c|}{ Nuclear hazards } & \multicolumn{4}{|c|}{ Nonnuclear hazards } & \multicolumn{4}{|c|}{ Natural phenomena hazards } & \multirow[b]{2}{*}{$\begin{array}{l}\text { Worker safety } \\
\text { hazards }\end{array}$} \\
\hline & Contamination & $\begin{array}{c}\text { Direct } \\
\text { radiation }\end{array}$ & Criticality & $\begin{array}{l}\text { Thermal } \\
\text { reaction }\end{array}$ & Explosion & Fire & $\begin{array}{l}\text { Loss of } \\
\text { support } \\
\text { utilities }\end{array}$ & Seismic & $\begin{array}{l}\text { Tornado } \\
\text { and high } \\
\text { winds }\end{array}$ & Floods & Volcanic ash & \\
\hline $\begin{array}{l}\text { General Design Critcria } \\
\text { DOE } 6430.1 \mathrm{~A}\end{array}$ & $\mathrm{x}$ & $\mathrm{x}$ & & $\mathrm{x}^{4}$ & $\mathrm{X}^{4}$ & $\mathrm{x}$ & $\mathrm{X}$ & $\mathrm{x}$ & $\mathrm{x}$ & $\mathrm{x}$ & & $x$ \\
\hline $\begin{array}{l}\text { Oceupational Radiation Protection } \\
10 \mathrm{CFR} 835\end{array}$ & $x$ & $\mathrm{x}$ & & & & & & & & & & \\
\hline $\begin{array}{l}\text { Nuclear Criticality Safety } \\
\text { DOE } 5480.24\end{array}$ & & & $\mathbf{x}$ & & & & & & & & & \\
\hline $\begin{array}{l}\text { Fire Protection } \\
\text { DOE } 5480.7 \\
\text { DOE-RL } 5480.7 A\end{array}$ & & & & & & $\begin{array}{l}\mathrm{x} \\
\mathrm{X}\end{array}$ & $\mathbf{x}$ & & & & & \\
\hline $\begin{array}{l}\text { NPH Mitigation } \\
\text { DOE } 5480.28\end{array}$ & & & & & & & & $\mathrm{X}$ & $\mathrm{x}$ & $\mathrm{x}$ & $\mathrm{x}$ & \\
\hline 29 CFR 1910 OSHA & & & & & & & $\mathbf{x}$ & & & & & $\mathrm{x}$ \\
\hline $\begin{array}{l}\text { NRC Equivalence } \\
\text { WHC-SD-SNF-DB-003 }\end{array}$ & $x^{1}$ & $\mathrm{X}^{2}$ & $\mathrm{X}^{3}$ & $\mathrm{X}^{4}$ & $\mathrm{X}^{4}$ & $x^{3}$ & $\mathbf{x}$ & $\mathrm{X}^{ో}$ & $\mathrm{X}^{6}$ & $x^{8}$ & & \\
\hline
\end{tabular}

Notes:

INRC Equivalence requirements from WHC-SD-SNF-DB-003, Table L, Items H12, 21, 23, and 25

${ }^{2} \mathrm{NRC}$ Equivalence requirements from WHC-SD-SNF-DB-003, Table 1 , fitems $\$ 20,21,23$, and 25

${ }^{3}$ NRC Equivalence requirements from WHC-SD-SNF-DB-003, Table 1, Items $\$ 8$ and 27

Thermal reaction and explosion hazards are safety class. NRC equivalence requirements are from WHC-SD-SNF-BB-003, Table 1, Items $\$ 3,4,7,10,11,15$, and 19

INRC equivalence requirements are from WHC-SD-SNF-DB-003, Table 1 , Item A1

'NRC equivalence requirements are from WHC-SD-SNF-DB-003, Table 1, Item $\# 2$ 
HNF-SD-SNF-DRD-002 REV 1

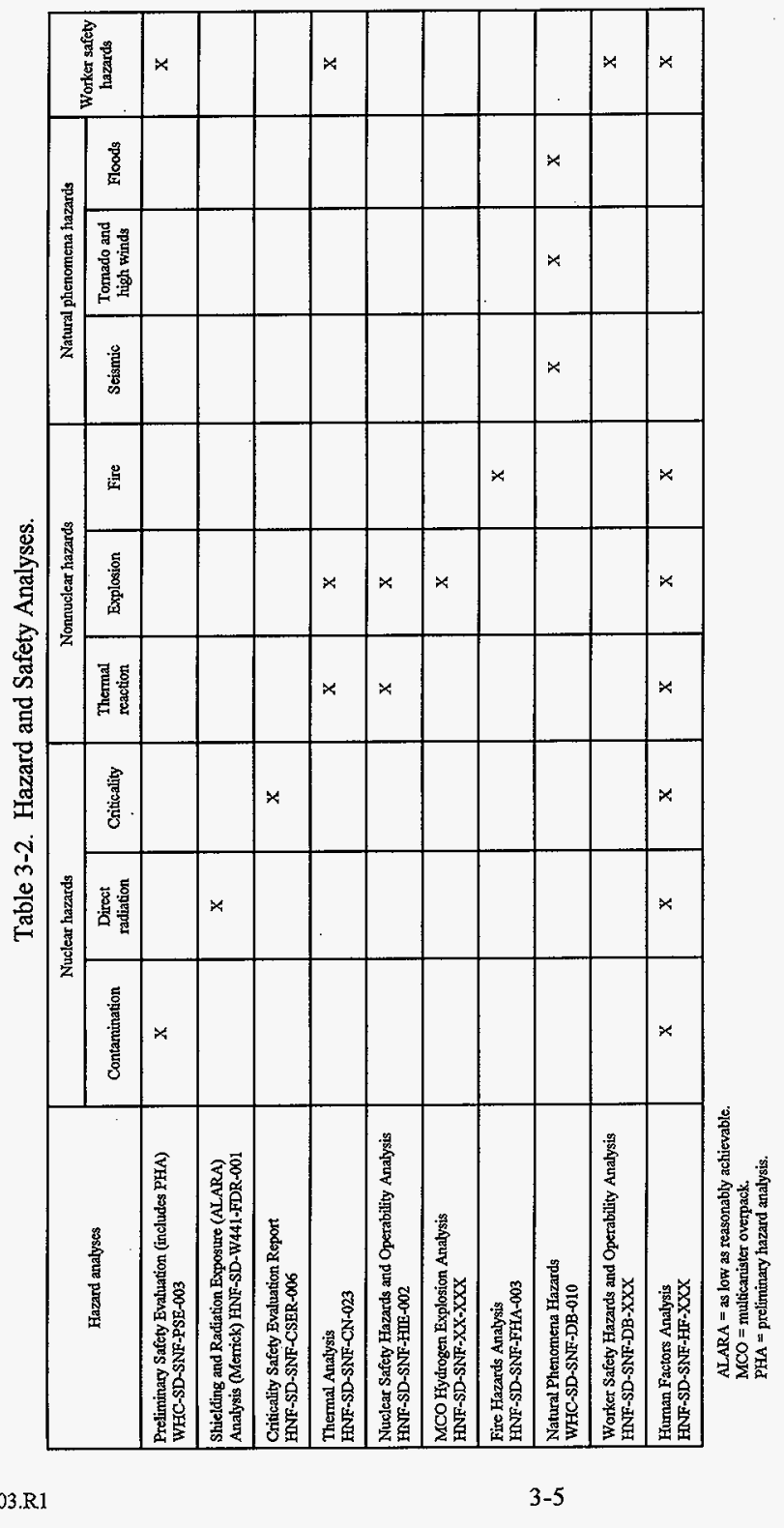


Table 3-3. Safety Analyses Design Bases and Requirements.

\begin{tabular}{|c|c|c|}
\hline Hazard analysis & Safety basis & Safety design requirements \\
\hline Preliminary Safety Evaluation & $\begin{array}{l}\text { Preliminary hazards analysis } \\
\text { Design basis accidents (process/facility initiated) } \\
\text { Design basis accident consequences } \\
\text { Safety classifications }\end{array}$ & $\begin{array}{l}\text { Hazard category } 2 \text { facility } \\
\text { DBAs and safety classifications: } \\
\text { Runaway corrosion/fuel ignition (SC) } \\
\text { MCO hydrogen explosion (SC) } \\
\text { Airborne/liquid release in process bay (SS) } \\
\text { Airborne/liquid release in tank room (SS) }\end{array}$ \\
\hline $\begin{array}{l}\text { Shielding and Radiation Exposure } \\
\text { Analysis }\end{array}$ & $\begin{array}{l}\text { Direct radiation hazard } \\
\text { Shielding and radiation control basis }\end{array}$ & None \\
\hline Criticality Safety Evaluation Report & Criticality control basis & $\begin{array}{l}\text { Vessels and tanks geometry control requirements } \\
\text { Vessels and tanks mass limits }\end{array}$ \\
\hline Thermal Analysis & $\begin{array}{l}\text { MCO/fuel thermal reaction control basis } \\
\text { MCO/firel hydrogen generation control basis }\end{array}$ & $\begin{array}{l}\text { Process thermal control requirements: } \\
\text { High fuel reactivity/surface area } \\
\text { Vacuum drying/He cooling time limits } \\
\text { Cask annulus water/helium gas temperature control limits } \\
\text { Hydrogen generation rates }\end{array}$ \\
\hline $\begin{array}{l}\text { Nuclear Safety Hazards and } \\
\text { Operability Analysis }\end{array}$ & $\begin{array}{l}\text { Process control basis for MCO/fuel thermal reaction and hydrogen } \\
\text { generation control } \\
\text { (Process design basis transients: thermal, pressure, hydrogen } \\
\text { control, effluent control, and process control) }\end{array}$ & $\begin{array}{l}\text { Process transients: } \\
\text { Loss of MCO helium purge } \\
\text { Loss of cask annulus water } \\
\text { Cask annulus water or he gas overtemperature } \\
\text { Process leak/break air ingress into MCO } \\
\text { Water ingress into } \mathrm{MCO} \text { above } 50^{\circ} \mathrm{C} \\
\text { Exceed vacuum } / \mathrm{He} \text { cooling time limits }\end{array}$ \\
\hline MCO Hydrogen Explosion Analysis & Hydrogen explosion within MCO control basis & $\begin{array}{l}\text { Hydrogen and air concentrations necessary for undesired level } \\
\text { of flammability/explosion event }\end{array}$ \\
\hline Fire Hazards Analysis & Fire accident consequences basis & Truck fuel fire in process bay \\
\hline Natural Phenomena Hazards & $\begin{array}{l}\text { Design basis natural phenomena hazard accidents } \\
\text { Natural phenomena hazard control basis }\end{array}$ & $\begin{array}{l}\text { PC-3 seismic, high wind, and floods } \\
\text { NRC equivalent tomado winds and floods }\end{array}$ \\
\hline $\begin{array}{l}\text { Worker Safety Hazards and } \\
\text { Operability Analysis }\end{array}$ & Worker safety controls basis & To be determined \\
\hline Human Factors Analysis & Man-machine interface control basis & To be determined \\
\hline
\end{tabular}

$\mathrm{MCO}=$ multicanister overpack.

$\mathrm{PC}=$ performance category.

$\mathrm{SC}=$ safety class 
The PSE for CVDF (WHC-SD-SNF-PSE-003) requires that SSCs whose failure could prevent safety-class or safety-significant SSCs from adequately performing their safety function, either by loss of control or monitoring function or by damage through physical interaction, are classified in correspondence with the SSC being protected.

\subsubsection{Preliminary Safety Evaluation}

The Preliminary Safety Evaluation for CVDF (WHC-SD-SNF-PSE-003) provides a preliminary hazard analysis. CVDF is categorized as a hazard category 2 (moderate hazard) facility in accordance with DOE-STD-1027-92.

The recommendations in the PSE for safety-class and safety-significant SSCs are derived from the guidelines in WHC-CM-4-46, Section 9.0, which implement DOE Order 6430.1A, Section 1300-3, "Safety Class Criteria," and from WHC-SD-SNF-DB-003, Spent Nuclear Fuel Project Path Forward Additional NRC Requirements (Garvin 1995), which identifies items to be considered in achieving NRC nuclear safety equivalency. The Westinghouse Hanford Company (WHC) system for classifying items is based on potential radiological releases should the item fail:

- Safety-class items are those SSCs whose failure may result in a release that will expose the public offsite to radiological doses in excess of $5 \mathrm{mSv}(0.5 \mathrm{rem})$ effective dose equivalent

- Safety-significant items are those SSCs whose failure may result in a release that will expose the onsite worker to radiological doses in excess of $10 \mathrm{~m} \mathrm{~Sv}(1 \mathrm{rem})$ effective dose equivalent.

SSCs whose failure could prevent safety-class or safety-significant SSCs from adequately performing their safety functions, either by loss of control or monitoring function or by damage through physical interaction, are classified in correspondence with the SSC being protected.

In addition, implementation of NRC nuclear safety equivalency has established an additional requirement for safety class 2 and 3 SSCs (now safety-significant SSCs) as documented in WHC-SD-SNF-DB-003, Spent Nuclear Fuel Project Path Forward, Additional NRC Requirements. NRC nuclear safety equivalency requires the use of a deterministic value of $50 \mathrm{mSv}(5 \mathrm{rem})$ in safety analyses for the onsite worker at the boundary of the controlled area (defined as $100 \mathrm{~m}$ [328 ft] from the facility release point) for DBAs to assist in determining safety class 2 and 3 SSCs (WHC-SD-SNF-DB-003). This is as opposed to the onsite probabilistic values in WHC-CM-4-46, Section 9.0.

Table 3-4 provides the preliminary list of safety-class and safety-significant SSCs that have been identified based on the above criteria and on the analysis in PSE (WHC-SD-SNF-DB-003). 
HNF-SD-SNF-DRD-002 REV 1

Table 3-4. Preliminary List of Safety-Class and Safety-Significant Functions Required by Accident Analysis for the Cold Vacuum Drying Facility.

\begin{tabular}{|l|l|l|c|}
\hline \multicolumn{1}{|c|}{ Safety function } & \multicolumn{1}{|c|}{ Function description } & Referenced accident analysis* & \multicolumn{1}{c|}{$\begin{array}{c}\text { Safety } \\
\text { classification }\end{array}$} \\
\hline MCO & Confinement & All accidents & Safety class \\
\hline $\begin{array}{l}\text { Process bay confinements } \\
\text { and process water tank } \\
\text { room }\end{array}$ & $\begin{array}{l}\text { Maintain a negative pressure } \\
\text { with respect to the surrounding } \\
\text { atmosphere for confinement of } \\
\text { releases }\end{array}$ & $\begin{array}{l}3.4 .2 .2 \text { Flammable Gas Ignition } \\
3.4 .2 .3 \text { MCO Overpressurization } \\
\text { S.4.2.6 Liquid Releases }\end{array}$ & Safety significant \\
\hline $\begin{array}{l}\text { Process systems and liquid } \\
\text { waste system confinement }\end{array}$ & $\begin{array}{l}\text { Confinement of liquid sprays or } \\
\text { spills and airborne releases }\end{array}$ & 3.4 .2 .6 Liquid Releases & Safety significant \\
\hline $\begin{array}{l}\text { MCO runaway fuel } \\
\text { corrosion/ignition } \\
\text { prevention }\end{array}$ & $\begin{array}{l}\text { Ensure the MCO fuel remains } \\
\text { thermally stable }\end{array}$ & 3.4 .2 .5 Fuel Ignition & Safety class \\
\hline $\begin{array}{l}\text { MCO hydrogen } \\
\text { deflagration/detonation } \\
\text { prevention }\end{array}$ & $\begin{array}{l}\text { Ensure the MCO atmosphere } \\
\text { remains nonflammable }\end{array}$ & 3.4 .2 .2 Flammable Gas Ignition & Safety class \\
\hline $\begin{array}{l}\text { Liquid waste criticality } \\
\text { control }\end{array}$ & $\begin{array}{l}\text { Prevent transfer and } \\
\text { accumulation of fuel fissile } \\
\text { material from the MCO to the } \\
\text { liquid waste system }\end{array}$ & NA & Safety class \\
\hline
\end{tabular}

*Sections referenced in this column are from HNF-SD-SNF-SAR-002, Safety Analysis Report for the Cold Vacuum Drying Facility, Phase 1, Supporting CivilStructural Construction, Rev, 1B, Fluor Daniel Hanford, Incorporated, Richland, Washington.

$\mathrm{MCO}=$ multicanister overpack .

$\mathrm{NA}=$ not applicable.

\subsubsection{Shielding and Radiation Exposure Analysis}

The radiological design of the CVDF shall incorporate the requirements of HSRCM-1, Hanford Site Radiological Control Manual, 10 CFR 835, "Occupational Radiation Protection," and DOE Order 6430.1A, General Design Criteria. In addition, the design shall use as a guideline WHC-SC-GN30011, Radiological Design Guide.

DOE requires that the maximum annual exposure to an individual from all sources must not exceed a cumulative $1,000 \mathrm{mrem}$, summed over all controlled access areas. Hanford Site requirements are that the maximum annual exposure to an individual from all sources be less than 500 mrem (HSRCM-1). Shielding designs shall be made ALARA in accordance with 10 CFR 835. 


\section{HNF-SD-SNF-DRD-002 REV 1}

ALARA shall be a designed-in operating principle to limit personnel and environmental exposures to the lowest level commensurate with sound economic and social considerations. ALARA shall mean conducting activities such that exposures to radiation are reduced to the lowest practical levels, considering the possible means of exposure reduction and the associated cost. The ALARA principle shall also apply to radioactive material releases to the environment and to both collective and individual doses.

The primary means of achieving ALARA doses shall be through physical controls such as shielding, automation to reduce exposure time, remote operations, equipment arrangement, and nuclear material confinement.

\subsubsection{Criticality Safety Evaluation Report}

The CVDF design shall comply with DOE Order 5480.24, Nuclear Criticality Safety, as implemented by WHC-CM-4-29, Nuclear Criticality Safety. The CVDF design will maintain criticality safety mandated spacing requirements during all DBAs. A Criticality Safety Evaluation Report for CVDF (HNF-SD-SNF-CSER-006) has been completed. The report provides the criticality requirements for safe design geometries and fuel loading configurations. The design shall incorporate the applicable and appropriate results, requirements and recommendations of this criticality safety evaluation report.

\subsubsection{Thermal Analyses}

The thermal analysis document, HNF-SD-SNF-CN-023, Thermal Analysis of Cold Vacuum Drying of Spent Nuclear Fuel, provides the safe operating conditions that maintain thermal stability of the fuel and prevent a runaway corrosion reaction. In addition, the thermal analysis provides hydrogen generation rates and concentrations within the MCO during normal and abnormal operating conditions for hydrogen control requirements (HNF-SD-SNF-CN-023). The thermal analysis safety bases for process operations are listed in Table 3-5.

\subsubsection{Nuclear Safety Hazards and Operability Study}

A process hazards and operability (HAZOP) study for CVDF (HNF-SD-SNF-HIE-002) identified abnormal or upset conditions that shall be considered in the design of the safety-class features for prevention of an MCO runaway corrosion reaction and/or hydrogen deflagration/detonation event. The design shall consider and incorporate the applicable and appropriate results, requirements and recommendations of this HAZOP. The incorporation of the HAZOP results in the design shall be documented. 
Table 3-5. Thermal Analysis Safety Basis Summary.

\begin{tabular}{|l|l|l|}
\hline \multicolumn{1}{|c|}{ Critical process transients } & \multicolumn{1}{|c|}{ Effects on MCO/fuel } \\
\hline MCO fuel excessive reactivity/surface area & $\begin{array}{l}\text { Excessive fuel heatup leading to runaway corrosion } \\
\text { reaction/fuel ignition }\end{array}$ & $\begin{array}{l}\text { Fuel loading controls on scrap basket } \\
\text { MCO reactivity test }\end{array}$ \\
\hline Cask annulus water overtemperature & $\begin{array}{l}\text { Excessive fuel heatup leading to runaway corrosion } \\
\text { reaction/fuel ignition }\end{array}$ & Cask annulus water temperature control \\
\hline Loss of cask annulus water & $\begin{array}{l}\text { Loss of MCO heat rejection leading to fuel heatup and } \\
\text { runaway corrosion reaction/fuel ignition }\end{array}$ & Cask annulus water level control \\
\hline Helium purge gas overtemperature & $\begin{array}{l}\text { Excessive fuel heatup leading to runaway corrosion } \\
\text { reaction/fuel ignition }\end{array}$ & Helium purge gas temperature control \\
\hline Loss of Helium purge gas flow & $\begin{array}{l}\text { Excessive hydrogen concentration in MCO (no effect } \\
\text { on MCO unless air ingress occurs) }\end{array}$ & Helium purge gas flow control \\
\hline Loss of process pressure control (air ingress) & $\begin{array}{l}\text { Air mixing with excessive hydrogen concentration } \\
\text { leading to MCO hydrogen detonation }\end{array}$ & Process pressure control \\
\hline Introduction of water into MCO above $50^{\circ} \mathrm{C}$ & $\begin{array}{l}\text { Excessive MCO water causing runaway corrosion } \\
\text { reaction/fuel ignition }\end{array}$ & Process water sources isolation control \\
\hline Excessive time under vacuum & $\begin{array}{l}\text { Excessive fuel heatup leading to runaway corrosion } \\
\text { reaction/fuel ignition }\end{array}$ & Process vacuum time control above $\mathrm{P}_{\mathrm{atm}}$ \\
\hline Insufficient time under helium cooling & $\begin{array}{l}\text { Excessive fuel temperature at start of vacuum cycle } \\
\text { leading to runaway corrosion/fuel ignition }\end{array}$ & Process helium time control above $\mathrm{P}_{\text {atn }}$ \\
\hline
\end{tabular}

$\mathrm{MCO}=$ multicanister overpack 


\section{HNNF-SD-SNF-DRD-002 REV 1}

\subsubsection{Multicanister Overpack Hydrogen Explosion}

To be developed.

\subsubsection{Fire Hazards}

A CVDF Fire Hazards Analysis (WHC-SD-SNF-FHA-003) has been completed. The design shall incorporate the applicable and appropriate results, requirements and recommendations of this fire hazards analysis. Exceptions to the design requirements can be made where waivers have been approved.

\subsubsection{Natural Phenomena Haxards}

The natural phenomena hazard (NPH) criteria for CVDF are defined in WHC-SD-SNF-DB-010, Cold Vacuum Drying System Natural Phenomena Hazards. This document specifies NPH loads for use in the design and construction of the CVDF, a facility that will be located in the $100 \mathrm{~K}$ Area of the Hanford Site. DOE requirements governing the derivation and mitigation of NPH loads are found in DOE Order 5480.28, Natural Phenomena Hazards Mitigation, and its supporting standards: DOE-STD-1020-94, Natural Phenomena Hazards Design and Evaluation Criteria for Department of Energy Facilities; DOE-STD-1022-94, Natural Phenomena Hazards Site Characteristics Criteria; and DOE-STD-1023-95, Natural Phenomena Hazards Assessment Criteria.

DOE regulatory policy for the design and construction of the Cold Vacuum Drying System requires a level of nuclear safety comparable to that of NRC-licensed facilities (Grumbly 1995). The NRC requirements appropriate for deriving NPH loads for the Cold Vacuum Drying System are found in Title 10, Code of Federal Regulations, Part 72, "Licensing Requirements for the Independent Storage of Spent Nuclear Fuel and High-Level Radioactive Waste" (10 CFR 72). With the exception of earthquake-induced ground motion, the compliance to both NRC and DOE requirements is accomplished by using the more stringent of the requirements for the design. The safety-class PC-3 NPH design loads for the CVDF are summarized in Table 3-6. The remainder of this document provides more detail on NPH loads and reviews the derivation of these loads.

The PC-3 criteria for the design basis seismic event are defined in WHC-SD-SNF-DB-010, and the design of SSCs shall be according to WHC-SD-SNF-DB-010. The seismic analysis or qualification will be in accordance with DOE-STD-1021-93, Natural Phenomena Hazards Performance Categorization Guidelines for Structures, Systems and Components. CVDF SSCs shall be designed to withstand the effects of seismic events.. Earthquake load for design basis earthquake (DBE) is defined by design spectra representing seismic ground motions at the surface. These spectra are associated with horizontal peak ground accelerations defined in WHC-SD-SNF-DB-010. 
Table 3-6. Cold Vacuum Drying System Safety-Class Performance Category 3 Natural Phenomena Design Loads.

\begin{tabular}{|c|c|c|}
\hline Hazard & Load & Application documents \\
\hline Seismic & $0.26 \mathrm{~g}$ equal hazard response spectra ${ }^{*}$ & $\begin{array}{l}\text { DOE Order } 5480.28^{b} \\
\text { DOE Standard } 1020-94^{\circ}\end{array}$ \\
\hline Straight wind & $129 \mathrm{~km} / \mathrm{h}(80 \mathrm{mi} / \mathrm{h})$, fastest mile at $9 \mathrm{~m}(30 \mathrm{ft})$ & $\begin{array}{l}\text { ASCE-7-93 } \\
\text { DOE Standard 1020-94 (including missiles) }\end{array}$ \\
\hline Tornado & $\begin{array}{l}\text { Wind speeds } \\
322 \mathrm{~km} / \mathrm{h}(200 \mathrm{mi} / \mathrm{h}) \text { total } \\
257 \mathrm{~km} / \mathrm{h}(160 \mathrm{mi} / \mathrm{h}) \text { rotational } \\
64 \mathrm{~km} / \mathrm{h}(40 \mathrm{mi} / \mathrm{h}) \text { transnational }\end{array}$ & $\begin{array}{l}\text { NRC Standard Review Plan } \\
\text { 3.3.2 Tornado Loading }\end{array}$ \\
\hline Volcanic ash & $117 \mathrm{~kg} / \mathrm{m}^{2}\left(24 \mathrm{lb} / \mathrm{ft}^{2}\right)$ ground ash load & $\begin{array}{l}\text { NRC Standard Review Plan } \\
\text { 3.8.4 Other Seismic Category Structures }\end{array}$ \\
\hline Flooding & $\begin{array}{l}\text { Columbia River: } 140 \mathrm{~m}(460 \mathrm{ft}) \text { above mean sea level } \\
\text { Site drainage basin: } 19 \mathrm{~cm}(7.4 \mathrm{in} \text {.) for 6-hour probable } \\
\text { maximum precipitation } \\
\text { Site drainage: } 23 \mathrm{~cm}(9.2 \mathrm{in} \text {.) for 6-hour probable maximum precipitation }\end{array}$ & $\begin{array}{l}\text { ANSI/ANS-2.8-1992 } \\
\text { NRC Standard Review Plan } \\
\text { 2.4.2 Floods }\end{array}$ \\
\hline Lightning & DOE-RL and RHO, Lightning protection shall be considered for facility. & NFPA $780^{8}$ \\
\hline Snow & $98 \mathrm{~kg} / \mathrm{m}^{2}\left(20 \mathrm{lb} / \mathrm{ft}^{2}\right)$ ground load & ASCE- $7^{d}$ \\
\hline
\end{tabular}

Note: Missiles are considered to strike surfaces in any direction, and the vertical velocities are $70 \%$ of the horizontal velocities except for the 1 -in steel rod, which has the same velocity in any direction. The utility pole and automobile are considered to strike surfaces up to maximum of $9.1 \mathrm{~m}(30 \mathrm{ft})$ above the highest finished grade within $0.8 \mathrm{~km}(0.5 \mathrm{mi})$ of the plant. The other missiles can strike at any elevation. These criteria are based on recent revision of the WNP- 2 tomado criteria by NRC:

- Parrish, J. V., 1995, WNP-2, Operating License NPF-21, Request for Approval to Revise Tornado Design Criteria, (letter GO2-95-212 to U.S. Nuclear Regulatory Commission, October 10), Washington Public Power Supply System, Richland, Washington

- Clifford, J. W., 1996, Revision of Tornado Design Criteria for the Washington Public Power Supply System (WPPSS) Nuclear Project No. 2 (WNP-2) (TAC No. 88626) (letter GL2-96-032 to J. V. Parrish, Washington Public Power Supply System, January 24), U.S. Regulatory Commission, Washington, D.C.

"Geomatrix, 1996, Probabilistic Seismic Hazard Analysis DOE Hanford Site, Washington, WHC-SD-W236A-TI-002, Rev. 1, prepared by Geomatrix Consultants, Incorporated, for Westinghouse Hanford Company, Richland, Washington.

'DOE.Order 5480.28, Natural Phenomena Hazards Mitigation, U.S. Department of Energy, Washington, D.C.

'DOE Standard 1020-94, Natural Phenomena Hazards Design and Evaluation Criteria for Department of Energy Facilities, U.S. Department of Energy, Washington, D.C.

dASCE, 1993, Minimum Design Loads for Building and Other Structures, ASCE-7-93, American Society of Civil Engineers, New York, New York.

'NRC, 1981, Standard Review Plan, NUREG-0800, U.S. Nuclear Regulatory Commission, Washington, D.C.

'ANSI/ANS, 1992, Determining Design Basis Flooding at Power Reactor Sites, ANSI/ANS-2.8-1992, American Nuclear Society, La Grange Park, Illinois.

'NFPA, 1992, Lightning Protection, NFPA 780, National Fire Protection Association, Quincy, Massachusetts. 
CVDF SSCs shall be designed to withstand the wind loading according to the requirements of WHC-SD-SNF-DB-010.

Although no design basis tornado missiles are considered credible for the CVDF, tornado wind loading shall be applied to SSCs in accordance with WHC-SD-SNF-DB-010.

The elevation of the CVDF site has been determined to be above the maximum extent of the design basis flood level and is not subject to regional flood hazards. However, the CVDF roof and site drainage systems may be subjected to rainfall that may cause local flooding. The local flooding shall be applied to the CVDF SSCs in accordance with WHC-SD-SNF-DB-010.

The CVDF is located in a geographic region where volcanic action may affect operation. The design of SSCs shall consider ash resulting from volcanic eruption according to WHC-SD-SNF-DB-010.

\subsubsection{Worker Safety Hazards}

To be developed.

\subsubsection{Human Factors Analysis}

Human factors consideration in the design of DOE facilities is required in DOE Order 6430.1A, General Design Criteria, Section 1300-12.4 (see Appendix A for applicable requirements). DOE has a draft standard, "Human Engineering Design Criteria, Volume I," that shall be used as a guideline for evaluating human factors considerations of the CVDF design. In addition, NRC equivalency (see Appendix B) requires that NUREG-0700, Human System Interface Design Review Guidelines, and NUREG-0800, Standard Review Plan, Section 18.1, "Human Factors Engineering, Control Room," be reviewed for additional applicable requirements above the DOE guidelines. Application of these guidelines shall be documented for the appropriate human factors interfaces (man-machine interfaces) of the safety-class SSCs. These include, but are not limited to, the following interfaces and activities:

- Operations interfaces (operator activities and task analysis)

- Process water tank room operations review

- Process bay operations review

- Control interfaces for normal, upset, and emergency or faulted conditions for

- Control room interfaces

- Process bay local controls and panels

- Testing, surveillance, and maintenance activities. 
HNF-SD-SNF-DRD-002 REV 1

\subsection{SAFETY FUNCTIONS AND DESIGN FEATURES}

The safety functions designated for protection against the facility hazards are listed in Table 3-7. Each hazard is controlled by a safety function which is composed of safety structures, systems and components (SSCs). The DBAs for safety classification of the SSCs are listed with the appropriate safety classification. The following subsections describe the safety functions and design features which are composed of SSCs.

The CVDF shall be designed to be safely shutdown in the event of a DBA or other stimuli (deemed appropriate by the designer as required by Division 13 of DOE Order 6430.1A). The safe shutdown condition shall be one that ensures that radioactive emissions from the facility do not exceed the allowable exposure limits.

\subsubsection{Confinement Features}

The CVDF shall have two levels of confinement. The primary confinement system shall consist of the MCO and the process piping of the VPS connected to the MCO, the TWS connected to the cask and the PWC system. The primary confinement system shall be a barrier that separates the radioactive material contained in the $\mathrm{MCO}$ and the process piping from spaces bounded by structures whose failure would offer a path for a radioactive release into the CVDF or into the stack stream.

The primary confinement shall be surrounded by secondary confinement structures and systems designed to confine radioactive material that may be released from the primary confinement in the event of an operational occurrence, such as a small release when disconnecting the process lines from the $\mathrm{MCO}$, or an accident. The secondary confinement shall protect the environment and people outside the building. The secondary confinement must withstand the effects of DBAs, including natural phenomena, so that it achieves its required release mitigation performance should one of these events occur. The CVDF building has been designed to withstand the design basis tornado and DBE so that it will not become a source of falling items or missiles that could threaten secondary confinement.

The secondary confinement structure shall be the process bays and process water tank room structures including parts of the secondary confinement ventilation system. Structural analysis shall demonstrate that the structure and ventilation system boundaries will not fail structurally as a result of DBA loads. The secondary confinement shall meet the PC-3 structural criteria.

The process water tank room and each individual process bay shall be tested for leak rate in accordance with ASTM E-779-87, Standard Test Method for Determining Air Leakage Rate by Fan Pressurization. The test shall be conducted to determine whether the natural air infiltration rate in air changes per hour using the Lawrence Berkeley Laboratory model (American Society of Heating, Refrigeration, and Air Conditioning Engineers [ASHRAE] Handbook of Fundamentals). 
Table 3-7. Hazards, Safety Functions, Design Basis Accidents, Safety Classifications and Structures, Systems, and Components.

\begin{tabular}{|c|c|c|c|c|c|}
\hline Hazards & Safety functions & Design basis accidents & Safety classification & Performance category & $\begin{array}{l}\text { Safety features } \\
\text { (structures and systems) }\end{array}$ \\
\hline \multirow[t]{2}{*}{ Contamination } & $\begin{array}{l}\text { Primary confinement - protection of facity workers } \\
\text { (AL_ARA) and facility contanination }\end{array}$ & $\begin{array}{l}\text { 1) Yacuum procsss lino leak/break } \\
\text { 2) MCO water drain line leakhreak } \\
\text { 3) Process water collection system leak/break }\end{array}$ & Safety-significant & $\mathrm{PC}-2$ & $\begin{array}{l}\text { MCO } \\
\text { VPS, TwS and PWCS piping and wessels } \\
\text { Ventilation exchaust ducting and HEPA filter }\end{array}$ \\
\hline & $\begin{array}{l}\text { Secondary confinement - protection of collocated } \\
\text { workers and envisonnental contamination }\end{array}$ & $\begin{array}{l}\text { 1) Vacuum process line break } \\
\text { 2) MCO water drain lino break in process bay } \\
\text { 3) MCO water spray/spill in process water tank room }\end{array}$ & Safety-significant & $\begin{array}{l}\text { PC-3 Structuro } \\
\text { PC-2 HVAC }\end{array}$ & $\begin{array}{l}\text { Process bays structure and ventilation } \\
\text { exhaust ducting and HEPA filter } \\
\text { Process water tark room. strieture and ventilation exhaust } \\
\text { ducting and HEPA filter }\end{array}$ \\
\hline \multirow[t]{2}{*}{ Direct rediation } & Controlled areas & NA & Genteral Services & NA & $\begin{array}{l}\text { Process bays and around cask } \\
\text { Process water tark room }\end{array}$ \\
\hline & Shielding & $\mathrm{NA}$ & General Services & $\mathrm{PC}-3$ cask-MCO and Trailer & $\begin{array}{l}\text { Cask-MCO } \\
\text { Process hood } \\
\text { Process bays and process water tank room walls }\end{array}$ \\
\hline Criticality & $\mathrm{K}_{4 \pi}<.95$ & NA & Safery class & PC. $-3^{1}$ & $\begin{array}{l}\text { MCO geometry } \\
\text { PWCS tank and geels geometry }\end{array}$ \\
\hline Chemical reaction & $\begin{array}{l}\text { Prevention of runaway corrosion reaction leading to fuel } \\
\text { ignition }\end{array}$ & Runaway corrosion reaction leading to fuel ignition & Safety class & $\mathrm{PC}-3$ & $\begin{array}{l}\text { Safety class instrumentation and control } \\
\text { Safety class helium system } \\
\text { Safety class VPS lines and Isolation } \\
\text { Safety class cask arnutus water protection }\end{array}$ \\
\hline Explosion & $\begin{array}{l}\text { Prevention of hydrogen delagration or detonation within } \\
\text { MCO }\end{array}$ & Hydrogen detonation within MCO & Safety class & $\mathrm{PC}-3$ & $\begin{array}{l}\text { Safety class instrumentation and control } \\
\text { Safety closs helium system. }\end{array}$ \\
\hline Fire & Protection of safefy class or safety-sigrificant SSCs & $\mathrm{NA}$ & General Services & $\mathrm{PC}-2$ & $\begin{array}{l}\text { Fire detoction, alarms and actuation } \\
\text { sprinklex systems }\end{array}$ \\
\hline Seismic & $\begin{array}{l}\text { Structural protection of saftey class and safety-significant } \\
\text { SSCs }\end{array}$ & Design basis earthquake & Safety-significant & PC-3 & $\begin{array}{l}\text { Process bays } \\
\text { Process water tank room }\end{array}$ \\
\hline $\begin{array}{l}\text { Tornedo and high } \\
\text { winds }\end{array}$ & $\begin{array}{l}\text { Structural protection of safety class and safety-significant } \\
\text { SSCs }\end{array}$ & $\begin{array}{l}\text { Design basis tomado winds } \\
\text { Design basis high winds }\end{array}$ & Safety-sigrificant & $\mathrm{PC}-3$ & $\begin{array}{l}\text { Process bays } \\
\text { Process water tank roorn }\end{array}$ \\
\hline Foods & Protection of safety class and safety-significant SSCs & Design basis flood & General Servicos & $\mathrm{PC}-3^{*}$ & Sito drainage systen \\
\hline $\begin{array}{l}\text { Worker safety } \\
\text { hazards }\end{array}$ & $\begin{array}{l}\text { Protection against worker fatality and multiple worker } \\
\text { serious injuries }\end{array}$ & NA & Safety-sigrificant & $\mathrm{PC}-2$ & To be determined \\
\hline
\end{tabular}

1) If criticality control is not affected by seismic fallure or floodin then this may be PC-2

2) The site drainage system is PC-3 for maximum precipitation only, see Section 3.3.8.

ALARA - as low as reasonably achievable.

HEPA = high-efficiency particulate air (filter)

$\mathrm{MCO}=$ multicarister overpeci

NA = not sppicabie.

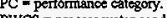

SSC - stuchess watem cond coning system

TWS =

VPS $=$ vaculum pumping system. 
for calculating effective leakage areas and estimated natural infiltration rates. Infiltration leakage sources shall be identified and sealed and the building retested until the building leak rate is ALARA.

All primary confinement vent paths and exhausts shall be vented through a separate normally contaminated HEPA-filtered exhaust system. The secondary confinement shall be ventilated so that its interior volume is held at a negative pressure under normal operation. The negative pressure is not required when there is a loss of normal operating power or DBE event. The secondary confinement ventilation air shall be exhausted through a dual-stage HEPA filter. The isolation dampers, duct, and filter housing shall be part of the secondary confinement structure.

Zoned Ventilation System. The ventilation system shall be designed to ensure that flow is from areas with the least potential for contamination to the areas with the greatest likelihood for contamination. Negative pressure shall ensure that air leakage flows from outside the process bays into the process bay areas and process water tank room. The negative pressure also shall extend into the operations areas where personnel are. Potentially contaminated air shall be withdrawn from the top of the MCO and exhausted through the ventilation system rather than being released into the bay.

Contamination Release Detection. Detection of released contamination shall be paramount to taking personnel protective actions and decontamination action. The design shall provide for the following detection methods.

a. Continuous air monitors shall be provided in the process areas where releases may occur.

b. The process bays and process water tank room shall have internal continuous air monitors. The internal continuous air monitor shall be used to inform the operator of a contamination release requiring investigation before entry into the bay or tank room.

c. The exhaust stack shall be continuously monitored in accordance with DOE Order 6430.1A, Sections 1589-1 through 1589-3 and 1589-99, to determine radioactive airborne effluent.

\subsubsection{Radiation Protection Features}

The following list of radiation protection features shall be considered and incorporated into the design of CVDF as appropriate to meet ALARA exposure requirements and design guidelines.

Engineering Controls. Engineering controls that should be considered to achieve ALARA goals include the following:

a. Confinement systems such as process piping, vessels and structural enclosures 
b. Ventilation systems that ensure negative pressure and flow toward the areas with highest contamination risk

c. Compartmentalization to isolate higher risk areas

d. Equipment location and arrangement so that servicing and replacement can be accomplished away from high risk areas

e. Waste treatment and handling systems to minimize releases

f. Inclusion of decontamination features

g. Automation of the process so that operators need not be present in the radiation field in order to operate the process

h. Arrangement designed so as to maximize the distance between operators and sources

i. Traps where radioactive material can accumulate in the systems minimized and provisions included for periodic decontamination of the process system

j. Local shielding to minimize source terms

k. Communication and observation systems to monitor operators when in the radiation field.

Maintenance Features. The following maintenance features should be considered to reduce exposure of personnel.

a. Use modular construction to speed replacement.

b. Provide for decontamination before beginning a replacement. Use ease of decontamination as a consideration when selecting equipment.

c. High or enhanced system performance to reduce maintenance requirements.

d. Select components that do not require lubrication or regular service.

\subsubsection{Criticality Prevention Features}

Criticality control is only required for the PWC system that collects $\mathrm{MCO}$ water with the potential to accumulate fuel from the MCO. The PWC system shall incorporate passive geometry control features to maintain criticality $\mathrm{K}_{\text {eff }}<.95$ under all normal, upset, or NPH conditions and provide double contingency control of all water transfers from geometrically safe tanks to uncontrolled volumes. 


\subsubsection{Multicanister Overpack Thermal Reaction Prevention Features}

An MCO runaway thermal corrosion reaction shall be prevented with the use of active detection and prevention features. These features shall consist of instrumentation monitoring the conditions important to maintaining thermal stability during the process. The instrumentation shall have activation logic associated with initiating a safe shutdown upon indication of unsafe thermal conditions. The safe shutdown shall be accomplished by initiating process MCO isolation and a timed helium purge to the MCO to purge hydrogen/air accumulations and maintain the $\mathrm{MCO}$ above atmospheric pressure. A dedicated safety-class instrumentation and control (SCI\&C) system shall provide the instrumentation and control features. Process isolation of the $\mathrm{MCO}$ is accomplished by closing the process lines isolation valves between the MCO and the VPS. The helium for safe shutdown shall be supplied by the safety-class helium (SCHe) system.

\subsubsection{Multicanister Overpack Fydrogen Deflagration/Detonation Prevention Features}

An MCO hydrogen deflagration/detonation event shall be prevented with the use of active detection and prevention features. These features shall consist of a normally operating helium purge supply and instrumentation monitoring the conditions important to maintaining hydrogen and/or air concentrations below flammability limits during the process. The instrumentation shall have activation logic associated with initiating a safe shutdown upon indication of unsafe conditions. The safe shutdown shall be accomplished by initiating process $\mathrm{MCO}$ isolation and providing a timed helium purge to the MCO to purge hydrogen/air accumulations. A dedicated SCI\&C system shall provide the instrumentation and control features. Process isolation of the $\mathrm{MCO}$ is accomplished by closing the process lines isolation valves between the MCO and the VPS. The helium for safe shutdown shall be supplied by the SCHe system.

\subsubsection{Fire Protection Features}

There is no identified fire hazard and therefore no design basis fire for the CVDF according to the Fire Hazards Analysis (WHC-SD-SNF-FHA-003). Fire sprinklers are provided for the entire facility and a fire detection and alarm system are part of the facility design in accordance with National Fire Protection Association (NFPA) requirements for fire protection.

\subsubsection{Natural Phenomena Hazard Mitigation Features}

The CVDF structure provides protection from seismic, high winds, and tornado winds. The process bays and process water tank room are PC-3 enclosures for seismic and wind protection. Equipment within these enclosures are qualified to $\mathrm{PC}-3$ requirements to not fail and impact the safety equipment required to accomplish and maintain a safe shutdown of the process.

DOE Order 5480.28 requires that each SSC be assigned to one of five performance categories based on safety class and hazard category. Each PC has an associated NPH goal that 
serves as a measure of the level of protection required against potential natural phenomena. The CVDF has been designated a hazard category 2 facility. Therefore, PC-2 (essential facilities) or PC-3 designation shall be assigned to all SSCs in accordance with the following criteria:

- PC-2 (essential facilities) is assigned to all general services SSCs with exception to those SSCs that because of failure may prevent a safety-class SSC from performing its safety function.

The administrative area, transfer corridor and mechanical room SSCs are designated PC-2.

- PC-2 (essential facilities) is assigned to all safety-significant SSCs with exception to those SSCs that because of failure may prevent a safety-class SSC from performing its safety function.

The safety-significant primary confinement systems are designated PC-2.

- PC-3 is assigned to all safety-class SSCs and to those SSCs whose failure may prevent a safety-class SSC from performing its safety function.

The process bays and process water tank room, which house safety-class systems, are PC-3. SSCs within these areas must be evaluated for potential to prevent safety-class SSCs from performing their safety function.

The CVDF site is above the probable maximum flood line for the Columbia River. The site drainage system provides protection against local flooding from precipitation.

\subsubsection{Worker Safety Hazards Protection Features}

Industrial Safety. The designer shall evaluate required codes, standards, and regulations for industrial safety. The designer shall identify any potential hazards to the health and safety of construction workers, operating personnel, and the public, or hazards that present a risk of significant program interruption. In matters of design, the safety and health of the building occupants shall take precedence over other aspects such as function, cost, or expediency. The designer shall include the following features for personnel safety as a minimum:

a. Observance of emergency egress requirements for a hazardous facility

b. Mechanical guards for exposed machinery

c. First aid kits, eyewashes, and safety showers

d. Clearly identified load ratings and certifications for lifting equipment; test capability for these items 
e. Clear identification of hazards by the use of signs or indicators

f. Facilities for dispensing protective clothing and respirators

g. Hazards detection and alarms systems

h. Design floor load limits posted for nongrade areas

i. Walking, driving, and working surfaces clearly designated for safety

j. Adequate storage areas for plant supplies, materials, equipment to preclude housekeeping problems

k. Safety interlocks for moving equipment to provide for personnel safety

1. Safe shutdown buttons for the process system easily available to plant operators.

Industrial Hygiene. The purpose of the industrial hygiene program shall be to anticipate and recognize health hazards arising out of operations and processes and to control the hazards. The CVDF shall be designed to maintain employee exposure to these hazards at a minimum. The design shall ensure that personnel exposure to chemical and physical agents shall not exceed the limits listed in the American Conference of Governmental Industrial Hygienists (ACGIH) latest threshold limit value booklet. The design shall ensure that the use of personnel protective equipment (e.g., respirators, hearing protection) shall not be required for normal operations. The hazards to be considered shall include chemical, physical, and ergonomic hazards:

a. Chemical hazards - these include excessive airborne concentrations of mists, vapors, gases, or solids that are in the form of dusts or fumes

b. Physical hazards-these include excessive noise, vibration, and nonionizing radiation as well as extremes of temperature and pressure

c. Ergonomic hazards - these include improper reaching or lifting situations, poor visual conditions, or repeated motion in awkward positions.

\subsection{SAFETY BASIS SUMMARY AND REQUUREMENTS}

The SSCs and applicable safety design requirements are summarized in Table 3-8. The CVDF shall be designed to achieve safe shutdown under all normal, abnormal, and NPH events. In addition, the SSCs shall be qualified to perform their safety functions under the normal and accident environmental conditions for which they are expected to function. The following subsections define the safe shutdown criteria, design basis events, and environmental qualification requirements for the SSCs. 


\subsubsection{Facility and Process Safe Shutdown}

Facility Safe Shutdown. No processing or transporting in progress and all process bays and tank room in hot shutdown, cold shutdown, hot standby, or cold standby.

Process Safe Shutdown. The MCO is considered in safe shutdown condition for the cold vacuum drying process if one of the following criteria are met:

- All MCO fuel covered with water and no MCO water drain path open

OR

- Wet MCO less than $50^{\circ} \mathrm{C}$ with proper water level in cask annulus (no longer than maximum time limit [ 8 hours] without proper water level in MCO cask annulus controlled by administrative procedures)

\section{AND}

- MCO volume purged of air or hydrogen and covered with helium

$$
\text { OR }
$$

- Dry MCO less than $75^{\circ} \mathrm{C}$.

\subsubsection{Design Basis Events}

Design basis events are composed of facility and/or process upset events and DBAs. The DBAs for design of safety-class systems are as follows:

- Hydrogen deflagration/detonation in the MCO

- Fuel runaway corrosion thermal reaction (loss of heat rejection).

A process HAZOP study for CVDF (HNF-SD-SNF-HIE-002) identified the following NPHs and upset conditions that shall be considered in the design of the safety-class features for prevention of an MCO runaway corrosion reaction and/or hydrogen deflagration/detonation event. The design basis process failure events applicable to the operation of the safety systems are as follows:

- Seismic event causing abnormal operating conditions that lead to a hydrogen deflagration/detonation or fuel runaway corrosion thermal reaction 
Table 3-8. Structure, System, and Component Safety Design Requirements. (2 sheets)

\begin{tabular}{|c|c|c|c|c|c|c|c|}
\hline \multirow{2}{*}{$\begin{array}{l}\text { Safety structures, systems and } \\
\text { components }\end{array}$} & \multicolumn{7}{|c|}{ Safety design requirements } \\
\hline & DOE $6430.1 \mathrm{~A}$ & 10 CFR 835 & DOE 5480.24 & DOE 5480.7 & DOE 5480.28 & 29 CFR 1910 & HNF-SD-SNF-DB-003 \\
\hline $\begin{array}{l}\text { Facility, site drainage and } \\
\text { utilities }\end{array}$ & Special facilities & HSRCM-1 & NA & NFPA & $\begin{array}{l}\text { PC-3 Flood } \\
\text { PC-2 Seismic } \\
\text { PC-2 High wind }\end{array}$ & TBD & $\begin{array}{l}\text { Flood } \\
\text { (WHC-SD-SNF-DB-010) }\end{array}$ \\
\hline $\begin{array}{l}\text { Process bay and tank room } \\
\text { structures }\end{array}$ & Safety-significant & HSRCM-1 & NA & NFPA & $\begin{array}{l}\text { PC-3 Seismic } \\
\text { PC-3 High wind }\end{array}$ & $\mathrm{TBD}$ & $\begin{array}{l}\text { Tomado winds } \\
\text { (WHC-SD-SNF-DB-010) } \\
10 \text { CFR 50, App R }\end{array}$ \\
\hline $\begin{array}{l}\text { Process bay and tank room } \\
\text { secondary confinements }\end{array}$ & Safety-significant & HSRCM-1 & NA & NFPA & $\begin{array}{l}\text { PC-2 Seismic } \\
\text { PC-2 High wind }\end{array}$ & TBD & NA \\
\hline $\begin{array}{l}\text { Secondary confinement } \\
\text { ventilation general exhaust } \\
\text { system }\end{array}$ & Safety-significant & HSRCM-1 & NA & NEPA & $\begin{array}{l}\text { PC-3 Seismic (within } \\
\text { process bay and tank } \\
\text { room only) }\end{array}$ & TBD & $\begin{array}{l}\text { ANSI/ANS N509 } \\
\text { ANSI/ANS N510 } \\
10 \text { CFR } 72.104\end{array}$ \\
\hline $\begin{array}{l}\text { Process bays recirculation } \\
\text { ventilation systems }\end{array}$ & Non-safety & HSRCM-1 & NA & NFPA & PC-3 Seismic & TBD & NA \\
\hline $\begin{array}{l}\text { VPS, TWS, PWCS primary } \\
\text { confinements }\end{array}$ & Safety-significant & HSRCM-1 & NA & NFPA & $\begin{array}{l}\text { PC-2 Seismic } \\
\text { PC-2 High Wind }\end{array}$ & TBD & $\begin{array}{l}\text { NRC Regulatory } \\
\text { Guide } 8.8\end{array}$ \\
\hline $\begin{array}{l}\text { Primary confinement } \\
\text { ventilation local exhaust } \\
\text { system }\end{array}$ & Safety-significant & HSRCM-1 & NA & NFPA & $\begin{array}{l}\text { PC-3 Seismic (within } \\
\text { Process Bay only) }\end{array}$ & TBD & $\begin{array}{l}\text { ANSU/ANS N509 } \\
\text { ANSU/ANS N510 } \\
10 \text { CFR } 72.104\end{array}$ \\
\hline Process hood & Safety- significant & HSRCM-1 & $\mathrm{NA}$ & NA & PC-3 Seismic & TBD & NA \\
\hline $\begin{array}{l}\text { Cask-trailer seismic restraint } \\
\text { system }\end{array}$ & Safety-significant & HSRCM-1 & NA & NA. & PC-3 Seismic & TBD & NA \\
\hline $\begin{array}{l}\text { PWCS, IXMs and storage tank } \\
\text { criticality control }\end{array}$ & Safety class & HSRCM-1 & $\begin{array}{l}\text { Criticality } \\
\text { Control }\end{array}$ & NA & PC-2 Seismic & TBD & $\begin{array}{l}\text { ANSI/ANS } 8.3 \\
\mathrm{~K}_{\mathrm{eff}}<.95\end{array}$ \\
\hline VPS SC isolation & Safety class & HSRCM-1 & NA & NA & PC-3 Seismic & TBD & IEEE 603-1991 \\
\hline $\begin{array}{l}\text { TWS cask annulus water } \\
\text { protection }\end{array}$ & Safety class & HSRCM-1 & NA & NA & PC-3 Seismic & TBD & IEEE 603-1991 \\
\hline
\end{tabular}


Table 3-8. Structure, System, and Component Safety Design Requirements. (2 sheets)

\begin{tabular}{|l|l|l|l|l|l|l|l|}
\hline \multirow{2}{*}{$\begin{array}{c}\text { Safety structures, systems and } \\
\text { components }\end{array}$} & \multicolumn{6}{|c|}{ Safety design requirements } \\
\cline { 2 - 8 } & DOE 6430.1A & 10 CFR 835 & DOE 5480.24 & DOE 5480.7 & DOE 5480.28 & 29 CFR 1910 & HNF-SD-SNF-DB-003 \\
\hline $\begin{array}{l}\text { SC instrumentation and control } \\
\text { system }\end{array}$ & Safety class & HSRCM-1 & NA & NA & PC-3 Seismic & TBD & IEEE 603-1991 \\
\hline SC helium system & Safety class & HSRCM-1 & NA & NA & PC-3 Seismic & TBD & IEEE 603-1991 \\
\hline Fire protection systems & Non-safety & HSRCM-1 & NA & NFPA & PC-2 Seismic & TBD & 10 CFR 50, App R \\
\hline
\end{tabular}

DOE $=$ U.S. Department of Energy.

LXM $=$ ion exchange module .

$\mathrm{NA}=$ not applicable

NFPA $=$ National Fire Protection Association

$\mathrm{NRC}=$ U.S. Nuclear Regulatory Commission.

$\mathrm{PC}=$ performance category.

i $\quad \mathrm{SC}=$ safety class.

心 $\mathrm{TBD}=$ to be determined. 
- Loss of process support utilities and functions causing abnormal operating conditions that could lead to a hydrogen deflagration/detonation or fuel runaway corrosion thermal reaction, including but not limited to

- Facility blackout (loss of offsite power and uninterruptible power supply [UPS])

- Loss of offsite power (UPS available)

- Loss of main $480 \mathrm{~V}$ ac power

- Loss of $120 \mathrm{~V}$ ac control power control functions

- Loss of monitor and control system (MCS) control signals to control functions

- Loss of instrument air to equipment

- Loss of cooling to facility loads

- Process boundary or isolation pressure control failure allowing air ingress into the MCO

- Process boundary or isolation failure allowing water ingress into the MCO when above $50{ }^{\circ} \mathrm{C}$

- Failure to return MCO to above atmospheric pressure with helium after exceeding the vacuum cycle time limit

- Failure of MCO to remain above atmospheric pressure with helium for minimum cooldown time

- Pipe breaks and other catastrophic failures leading to impacts preventing the safety-class SSCs within the process bay from performing their safety functions (e.g., pipe whip, water deluge, high-pressure air impact).

The above DBAs, NPHs, and process upset events shall be evaluated and considered in the design of all safety-class SSCs. Safety-class SSCs shall be capable of providing safe shutdown of the process under the conditions specified in this section. A list of DBA and/or process upset events (initiating events) and plant conditions associated with each initiating event is shown in Table 3-9. The plant conditions are considered design basis conditions for each of the listed initiating events.

\subsubsection{Environmental Qualification}

All safety components shall be designed to function under worst-case internal and external environmental conditions. These conditions are composed of faulted and process upset event plant conditions identified in Section 2.2.10 and the associated internal and external environmental conditions listed in Table 3-10 for each safety-class system. Safety-class detection or protection shall be provided where the design cannot guard against these impacts. The design shall mitigate those conditions that represent a potential common-mode failure of the safety-class system, and documentation shall be provided for those mitigation features. 


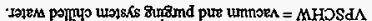

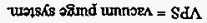
yddns rasod эqudnupiuntu = San

यมี

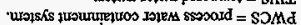

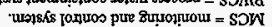

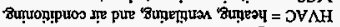

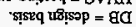
IOLS Pिाइए $=$ MHO

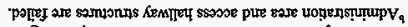

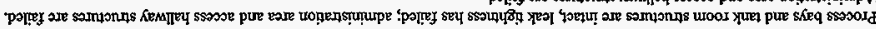

\begin{tabular}{|c|c|c|c|c|c|c|c|c|c|c|c|}
\hline YYO & X్ & YO & Xo & xo & xro & Xo & 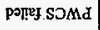 & Xo & স্ХO & Yes] so yearq Arepunoq SDMd & $Z \mathbf{I}$ \\
\hline YYO & X्र० & Y्र० & Yo & Y्र० & Yo & צ' & YO & sPगाRI SMI. & Yo & 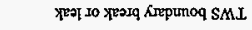 & II \\
\hline xo & YO & xo & Yo & Y्र० & Yo & Yo & प्र० & pगाएy SdA & YXo & 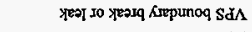 & oI \\
\hline PРाए. & PAाँEI & PATE:A & xo & X్ & Yo & Xo & X्र० & xo & X्र० & 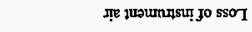 & 6 \\
\hline YO & צo & Ү्र० & Xo & Y्र० & Yо & priter & XY & प्र० & YO & SOWJo ssoT & 8 \\
\hline pभा़ा & port: & peped & pथाएद्य & X्रO & Yo & pथाter & Xo & YXo & Xo & 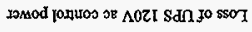 & $L$ \\
\hline POFE & pərney & ports & (sdn) Xo & poTg: & Xo & (S及م) >10 & YOo & Xo & Yo & 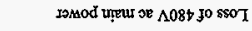 & 9 \\
\hline Pिएक्ष & pretgi & POITEA & (sdn) yo & poIPE & pगाter & (sda) Y \о & Yo & YO & Х्र० & 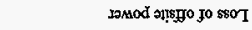 & $\varsigma$ \\
\hline poiser & PPIted & potrey & Pगाएद्म & pontea & Yo & pशा:्य & X్ & Yo & Xo & Eare proddne ur ang & $\rightarrow$ \\
\hline pगाक्ष्प & peptes & pəTाE & pəritg. & pəonga & P्गुË & Poiteg & YO & X्र० & प्र० & InOYNQTQ AIILE] & $\varepsilon$ \\
\hline Pिाद्य & popter & priegr & Pश्स. & pome & porret & patges & प्र० & प्र० & 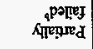 & opewol to/pux spugas ga & $\tau$ \\
\hline pertegr & potreg & pगा: & porter & porter & porgeg & ретед & 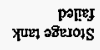 & xo & 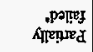 & opussas gd & I \\
\hline $\begin{array}{l}\text { Surols } \\
\text { OVAH }\end{array}$ & 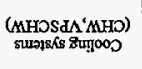 & 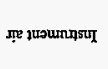 & $\begin{array}{l}\text { somod posuros } \\
\text { oe A0zा } \\
\text { San }\end{array}$ & 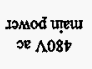 & 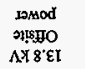 & $\begin{array}{l}\text { woor jonuos } \\
\text { pur SDW }\end{array}$ & $\begin{array}{l}\text { Srepunoq } \\
\text { somd } \\
\text { Sreuty.d }\end{array}$ & 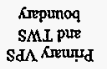 & armonas & \multirow[t]{2}{*}{ 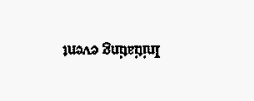 } & \multirow[t]{2}{*}{$o_{N}$} \\
\hline \multicolumn{10}{|c|}{ 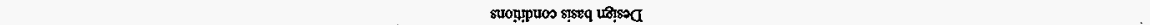 } & & \\
\hline
\end{tabular}


Table 3-10. Environmental Qualification Requirements for General Services, Safety-Significant and Safety-Class Structures, Systems, and Components.

\begin{tabular}{|c|c|c|c|c|c|c|c|c|c|}
\hline \multirow{3}{*}{ No. } & \multirow{3}{*}{ Plant state } & \multicolumn{8}{|c|}{ Service conditions } \\
\hline & & \multicolumn{4}{|c|}{ External } & \multirow{2}{*}{$\begin{array}{c}\text { Internal } \\
\text { Contamination }\end{array}$} & \multirow{2}{*}{ Radiation } & \multirow{2}{*}{ Vibration } & \multirow{2}{*}{ Duty cycle } \\
\hline & & Temperature & Pressure & Humidity & Contamination & & & & \\
\hline 1 & Normal conditions & $40^{\circ} \mathrm{F}-130^{\circ} \mathrm{F}$ & Ambient & $0 \%-100 \%$ & Dirt/dust & System Specific & $\begin{array}{l}\text { System } \\
\text { location } \\
\text { specific }\end{array}$ & $\begin{array}{l}\text { Frequency } \\
\text { (TBD) }\end{array}$ & Time in use \\
\hline 2 & Upset conditions & $\mathrm{NC}$ & $\mathrm{NC}$ & $\mathrm{NC}$ & $\mathrm{NC}$ & $\mathrm{NC}$ & $\mathrm{NC}$ & NA & NA \\
\hline 3 & Contamination release & $\mathrm{NC}$ & $\mathrm{NC}$ & $\mathrm{NC}$ & $\begin{array}{l}\text { Dirt/dust } \\
\text { radiation }\end{array}$ & $\begin{array}{l}\text { Dirt/dust } \\
\text { radiation }\end{array}$ & $\mathrm{NC}$ & NA & NA \\
\hline 4 & $\begin{array}{l}\text { Loss of power, cooling, } \\
\text { or HVAC }\end{array}$ & $130^{\circ} \mathrm{F}$ & $\mathrm{NC}$ & $\mathrm{NC}$ & $\mathrm{NC}$ & $\mathrm{NC}$ & $\mathrm{NC}$ & NA & NA \\
\hline 5 & $\begin{array}{l}\text { Process equipment } \\
\text { explosion }\end{array}$ & NC & $\mathrm{NC}$ & $\mathrm{NC}$ & $\mathrm{NC}$ & $\mathrm{NC}$ & $\mathrm{NC}$ & NA & NA \\
\hline 6 & Fire & $\mathrm{NC}$ & TBD & $100 \%^{\mathrm{a}}$ & Smoke & Smoke & $\mathrm{NC}$ & NA & NA \\
\hline 7 & Seismic event & $130^{\circ} \mathrm{F}$ & $\mathrm{NC}$ & $\mathrm{NC}$ & $\mathrm{NC}$ & $\mathrm{NC}$ & $\mathrm{NC}$ & NA & NA \\
\hline 8 & Tornado and high winds & $130^{\circ} \mathrm{F}$ & $\mathrm{NC}$ & NC & $\mathrm{NC}$ & $\mathrm{NC}$ & $\mathrm{NC}$ & NA & NA \\
\hline 9 & Floods & $130^{\circ} \mathrm{F}$ & NC & $\mathrm{NC}$ & NC & NC & $\mathrm{NC}$ & NA & NA \\
\hline
\end{tabular}

asprinklers are actuated and all equipment is deluged with water.

HVAC $=$ heating, ventilating, and air conditioning.

$\mathrm{NA}=$ not applicable.

$\mathrm{NC}=$ normal conditions.

TBD $=$ to be determined. 
HNF-SD-SNF-DRD-002 REV 1

\subsection{REFERENCES}

10 CFR 72, "Licensing Requirements for the Independent Storage of Spent Nuclear Fuel and High-Level Radioactive Waste," Code of Federal Regulations, as amended.

10 CFR 50, "Domestic Licensing of Production and Utilization Facilities," Code of Federal Regulations, as amended.

10 CFR 835, "Occupational Radiation Protection," Code of Federal Regulations, as amended.

29 CFR 1910, "Occupational Safety and Health Standards," Code of Federal Regulations, as amended.

ANSI/ANS-8.3-1986, 1986, Criticality Accident Alarm System, American Nuclear Society, La Grange Park, Illinois.

ANSI/ASME N509-1989, 1989, Nuclear Power Plant Air Cleaning Units and Components New Construction and Modification Only, American Society of Mechanical Engineers, New York, New York.

ANSI/ASME N510-1989, 1989, Testing of Nuclear Air-Cleaning Systems, American Society of Mechanical Engineers, New York, New York.

ASHRAE, 199, Handbook of Fundamentals, American Society of Heating, Refrigerating, and Air-Conditioning Engineers, Atlanta, Georgia.

ASTM E-779-87, 1987, Standard Test Method for Determining Air Leakage Rate by Fan Pressurization, American Society for Testing and Materials, Phiadelphia, Pennsylvania.

DOE Order 5480.7A, 1993, Fire Protection, U.S. Department of Energy, Washington, D.C.

DOE Order 5480.24, 1992, Nuclear Criticality Safety, U.S. Department of Energy, Washington, D.C.

DOE Order 5480.28, Natural Phenomena Hazards Mitigation, U.S. Department of Energy, Washington, D.C.

DOE Order 6430.1A, 1989, General Design Criteria, DOE 6430.1A, U.S. Department of Energy, Washington, D.C.

DOE-STD-1020-94, 1994, Natural Phenomena Hazards Design and Evaluation Criteria for Department of Energy Facilities, U.S. Department of Energy, Washington, D.C.

DOE-STD-1021-93, 1993, Natural Phenomena Hazards Performance Categorization Guidelines for Structures, Systems and Components, U.S. Department of Energy, Washington, D.C. 
DOE-STD-1022-94, 1994, Natural Phenomena Hazards Site Characteristics Criteria, U.S. Department of Energy, Washington, D.C.

DOE-STD-1023-95, 1995, Natural Phenomena Hazards Assessment Criteria, U.S. Department of Energy, Washington, D.C.

DOE-STD-1027-92, 1992, Hazard Categorization and Accident Analysis Techniques for Compliance with DOE Order 5480.23, Nuclear Safety Analysis Reports, U.S. Department of Energy, Washington, D.C.

DOE Standard XXXX-96, 1996, Human Engineering Design Criteria, DOE-STD-XXXX-96, Volume I, Draft, U.S. Department of Energy, Washington, D.C.

Grumbly, T. P., 1995, Concurrence with the K-Basins Spent Nuclear Fuel Project Policy on Nuclear Safety Requirements (Memorandum EM-36-3.1.6.7 to Manager, U.S. Department of Energy, Richland Operations Office, July 20), U.S. Department of Energy, Washington D.C.

HNF-S-0435, Performance Specification for the K Basin SNF Cold Vacuum Drying Facility Low Temperature Vacuum Drying Module, Fluor Daniel Hanford, Incorporated, Richland, Washington.

HNF-SD-SNF-CN-023, 1997, Thermal Analysis of Cold Vacuum Drying of Spent Nuclear Fuel, Fluor Daniel Hanford, Incorporated, Richland, Washington.

HNF-SD-SNF-CSER-006, 1997, Criticality Safety Evaluation Report for the Process Water Collection System at the Cold Vacuum Drying Facility, Rev. 0, Fluor Daniel Hanford, Incorporated, Richland, Washington.

HNF-SD-SNF-DB-003, 1997, Spent Nuclear Fuel Project Path Forward, Additional NRC Requirements, Rev. 3, Fluor Daniel Northwest for Fluor Daniel Hanford, Incorporated, Richland, Washington.

HNF-SD-SNF-FHA-003, 1996, Preliminary Fire Hazard Analysis for the Cold Vacuum Drying System Facility, Rev. 0, Westinghouse Hanford Company, Richland, Washington.

HNF-SD-SNF-HIE-002, 1997, Cold Vacuum Drying Facility Process Safety Class HAZOP Analysis, Rev. 0, Draft, Fluor Daniel Northwest for Fluor Daniel Hanford, Incorporated, Richland, Washington.

HNF-SD-SNF-SAR-003, 1996, Safety Analysis Report for the Cold Vacuum Drying Facility, Phase I, Supporting Civil/Structural Construction, Rev. 1B, Fluor Daniel Hanford, Incorporated, Richland, Washington 
HNF-SD-W441-FDR-001, 1997, Cold Vacuum Drying Facility Final Design Report, Rev. 0, Draft, Fluor Daniel Hanford, Incorporated, Richland, Washington.

HSRCM-1, Hanford Site Radiation Control Manual, Westinghouse Hanford Company, Richland, Washington.

IEEE 603-1991, 1991, Standard Criteria for Safety Systems, Institute of Electrical and Electronics Engineers, Piscataway, New Jersey.

NUREG-0700, 1995, Human System Interface Design Review Guidelines, U.S. Nuclear Regulatory Commission, Washington, D.C.

NUREG-0800, ,1984, Standard Review Plan, Section 18.1, "Human Factors Engineering, Control Room," U.S. Nuclear Regulatory Commission, Washington, D.C.

Regulatory Guide 8.8, 1982, Information Relevant to Ensuring that Occupational Radiation Exposures at Nuclear Power Stations will be as Low as is Reasonably Achievable, U.S. Nuclear Regulatory Commission, Washington, D.C.

Sellers, E. D., 1996, Contract Number DE-AC06-96RL13200: Proposed Spent Nuclear Fuel Project Division (SFD) Risk Acceptance Guidelines (RAGs) (Letter 96-SFD-318 to H. J. Hatch, President, Fluor Daniel, Incorporated, December 12), U.S. Department of Energy, Richland Operations Office, Richland, Washington.

WHC-CM-4-2, Quality Assurance Manual, Westinghouse Hanford Company, Richland, Washington.

WHC-CM-4-46, Safety Analysis Manual, Westinghouse Hanford Company, Richland, Washington.

WHC-SD-GN-DGS-30006, 1996, Guidelines for Assessing the Seismic Adequacy of Existing Performance Category Equipment at the Hanford Site, Rev. 1-A, Westinghouse Hanford Company, Richland, Washington.

WHC-SD-SNF-DB-003, 1996, Spent Nuclear Fuel Project Path Forward, Additional NRC Requirements, Rev. 2, Westinghouse Hanford Company, Richland, Washington.

WHC-SD-SNF-DB-010, 1996, Cold Vacuum Drying System Natural Phenomena Hazards, Rev. 1, Westinghouse Hanford Company, Richland, Washington.

WHC-SD-SNF-PSE-003, 1996, Preliminary Safety Evaluation for the Spent Nuclear Fuel Project's Cold Vacuum Drying Facility, Rev. 0, Westinghouse Hanford Company, Richland, Washington. 
HNF-SD-SNF-DRD-002 REV 1

This page intentionally left blank. 


\subsection{QUALITY ASSURANCE REQUIREMENTS}

\subsection{SOURCES}

The quality assurance requirements for design activities for the CVDF are derived from federal statutes and SNF Project-imposed NRC nuclear safety equivalency requirements. The quality assurance requirements sources are listed in Table 4-1.

\subsection{QUALITY ASSURANCE PROGRAM}

CVDF design activities shall be performed and controlled in accordance with a documented and approved quality assurance program that meets the applicable requirements of the source documents. These applicable requirements have been summarized in WHC-SD-W441-QAPP-001, Quality Assurance Program Plan Project W-441 Spent Nuclear Fuel Cold Vacuum Drying Facility.

\subsection{DESIGN EXECUTION}

Design control activities for all project participants involved in development, design, procurement, construction, or testing shall be formulated and executed to comply with the applicable quality assurance requirements in the CVDF Project Quality Assurance Program Plan, and shall provide the following assurances.

- Design data and design decisions are documented and traceable.

- The design and design criteria are adequately supported by the prepared plans, specifications, and analyses.

- The design meets the baseline design criteria.

- Construction is performed in accordance with the detailed design documents.

- Inspection and testing will confirm the adequacy of design, the quality of construction and manufactured components, operability and maintainability, and reliability. 
Table 4-1. Cold Vacuum Drying Facility Quality Assurance Requirements Sources.

\begin{tabular}{|c|c|c|}
\hline \multicolumn{3}{|c|}{ Federal Statutes and U.S. Department of Energy Quality Assurance Documents } \\
\hline Document & Title/date & Applicability \\
\hline 10 CFR 830.120 & $\begin{array}{l}\text { "Nuclear Safety Management," "Quality } \\
\text { Assurance Requirements" }\end{array}$ & All SSCs \\
\hline 10 CFR 72, Subpart G & $\begin{array}{l}\text { "Licensing Requirements for the Independent } \\
\text { Storage of Spent Nuclear Fuel and High Level } \\
\text { Radioactive Waste," "Quality Assurance" }\end{array}$ & CVDF Safety class SSCs \\
\hline DOE/RW/0333P & $\begin{array}{l}\text { Quality Assurance Requirements and } \\
\text { Description, Office of Civilian Radioactive } \\
\text { Waste Management }\end{array}$ & (See HNF-SD-SNF-RPT-007) \\
\hline \multicolumn{3}{|c|}{ Project Hanford Management Contract Documents } \\
\hline $\begin{array}{l}\text { WHC-CM-4-2 } \\
\text { (HNF-MP-599) }\end{array}$ & $\begin{array}{l}\text { Quality Assurance Manual } \\
\text { (Project Honford Quality Assurance Program } \\
\text { Description, 7-1-97, effective 10-30-97) }\end{array}$ & SNE Project \\
\hline $\begin{array}{l}\text { WHC-SP-1131 } \\
\text { (HNE-SP-1228) }\end{array}$ & $\begin{array}{l}\text { Westinghouse Hanford Company Quality } \\
\text { Assurance Program and Implementation Plan } \\
\text { (Quality Assurance Program Implementation } \\
\text { Plan for Nuclear Facilities, } 7-1-97 \text {, effective } \\
\text { 10-30-97) }\end{array}$ & SNF Project \\
\hline \multicolumn{3}{|c|}{ SNF and CVDF Project Documents } \\
\hline HNF-SD-SNF-QAPP-004 & $\begin{array}{l}\text { Spent Nuclear Fuel Project Quality Assurance } \\
\text { Progran Plan }\end{array}$ & SNF Project \\
\hline WHC-SD-W441-QAPP-001 & $\begin{array}{l}\text { Quality Assurance Program Plan Project } \\
\text { W-44I Spent Nuclear Fuel Cold Vacuum } \\
\text { Drying Facility }\end{array}$ & CVDF Project \\
\hline HNF-SD-SNF-DB-003 & $\begin{array}{l}\text { SNF Project Path Forward Additional NRC } \\
\text { Requirements }\end{array}$ & CVDF Safety Class SSCs \\
\hline
\end{tabular}

$\mathrm{CVDF}=$ Cold Vacuum Drying Facility.

DOE $=$ U.S. Department of Energy.

SNF = spent nuclear fuel.

SSC = structure, system, or component. 


\subsection{GRADED APPROACH}

Quality assurance requirements for the design process and for quality assurance and quality control requirements included in the design output documents are applied using a graded approach. The basis for the grading process shall be the relative safety risk posed to the public, the environment, and to Hanford Site personnel. The relative safety risk associated with an SSC is categorized by safety designations. In accordance with HNF-PRO-516, Safety Structures, Systems, and Components, the safety designations for the CVDF are safety class, safety significant, and general service. Safety-class SSCs contain the highest relative safety risk and require the most stringent controls. General service SSCs pose the lowest risk and therefore, at a minimum, require quality assurance and quality control commensurate with the codes and standards appropriate for nonnuclear commercial projects.

\subsection{SAFETY CLASSIFICATIONS}

The design shall identify the appropriate safety classification for all SSCs. The classification shall be readily identified on the design output documents or through other acceptable means as approved by the Project.

\subsection{REFERENCES}

10 CFR 830, "Nuclear Safety Management," Section 830.120, "Quality Assurance Requirements," Code of Federal Regulations, as amended.

10 CFR 72, "Licensing Requirements for the Independent Storage of Spent Nuclear Fuel and High Level Radioactive Waste," Subpart G, "Quality Assurance," Code of Federal Regulations, as amended.

DOE/RW/0333P, 1996, Quality Assurance Requirements and Description, Office of Civilian Radioactive Waste Management, U.S. Department of Energy, Washington, D.C.

HNF-MP-599, 1997, Project Hanford Quality Assurance Program Description, Rev. 0, Fluor Daniel Hanford, Incorporated, Richland, Washington.

HNF-PRO-516, 1997, Safety Structures, Systems, and Components, Fluor Daniel Hanford, Incorporated, Richland, Washington.

HNF-SD-SNF-DB-003, 1997, Spent Nuclear Fuel Project Path Forward, Additional NRC Requirements, Rev. 3, Fluor Daniel Hanford, Incorporated, Richland, Washington.

HNF-SD-SNF-QAPP-004, 1997, Spent Nuclear Fuel Project Quality Assurance Program Plan, Rev. 1, Fluor Daniel Hanford, Incorporated, Richland, Washington. 


\section{HNF-SD-SNF-DRD-002 REV 1}

HNF-SP-1228, Quality Assurance Program Implementation Plan for Nuclear Facilities, Fluor Daniel Hanford, Incorporated, Richland, Washington.

WHC-CM-4-2, Quality Assurance Manual, Westinghouse Hanford Company, Richland, Washington.

WHC-SD-W441-QAPP-001, Quality Assurance Program Plan Project W-441 Spent Nuclear Fuel Cold Vacuum Drying Facility, Rev. 0, Westinghouse Hanford Company, Richland, Washington.

WHC-SP-1 131, 1996, Westinghouse Hanford Company Quality Assurance Program and Implementation Plan, Rev. 1, Westinghouse Hanford Company, Richland, Washington. 


\subsection{PROCESS SYSTEM DESIGN REQUIREMENTS}

The CVDF process systems discussed in this section include the VPS, TWS, PWC system, which includes sampling, SCHe system, and the SCI\&C system. The CVDF process flow diagrams for these systems are detailed on drawings H-1-81166 and H-1-81182.

\subsection{PROCESS GENERAL REQUTREMENTS}

DOE Order 6430.1A, General Design Criteria, provides overall general design requirements applicable to all structures, systems and components. The applicable sections of DOE Order 6430.1A for CVDF are listed in Appendix A. The applicability of these sections is based on the CVDF being designated a nuclear facility under "special facilities," which includes consideration of design requirements under Section 1304, "Plutonium Processing and Handling Facilities," and Section 1324, "Irradiated Fissile Material Storage Facilities."

The following general requirements subsections list the general requirements applicable to all of the process systems in Chapter 5.0. These general requirements are applicable in addition to the system-specific requirements found in Sections 5.2 through 5.6.

\subsubsection{Process Functional Requirements}

The general process requirements from Chapter 2.0 are summarized and listed in Table 5-1. Table 5-1 assigns these process functional requirements to the appropriate process systems and components in this section.

5.1.1.1 Equipment Classification, Codes and Standards. All SSCs in the CVDF shall be tabulated in a facility equipment list. Appendix $\mathrm{E}$ provides a sample equipment list format. This table shall list SSC classification category, NPH PC, design codes and standards, quality assurance requirements, and supporting design information.

Table 5-2 defines the codes and standards to be us for the design of the CVDF process systems, structures, and components (SSCs). Each SSC shall be assigned one of the following classification categories: general services, safety significant, or safety class. General services is the non-safety classification category and safety significant and safety class are the two safety classification categories. All CVDF SSCs shall be assigned the general services category unless assigned to one of the two safety classification categories. 
Table 5-1. Process and Safety Functional Requirements.

\begin{tabular}{|c|c|c|c|c|c|c|}
\hline \multirow[b]{2}{*}{ Section } & \multirow[b]{2}{*}{ Functional Requirements } & \multicolumn{5}{|c|}{ Systems } \\
\hline & & $\begin{array}{l}\text { Vacuum Purge } \\
\text { System (VPS) }\end{array}$ & $\begin{array}{l}\text { Tempered Water } \\
\text { System (TWS) }\end{array}$ & $\begin{array}{l}\text { Process Water } \\
\text { Conditioning } \\
\text { System (PWCS) }\end{array}$ & $\begin{array}{l}\text { Safety Class } \\
\text { Felium (SCHe) } \\
\text { System }\end{array}$ & $\begin{array}{l}\text { Safety Class } \\
\text { Instrumentation and } \\
\text { Control (SCI\&C) } \\
\text { Systerm }\end{array}$ \\
\hline \multicolumn{7}{|c|}{ Process Functional Requirements } \\
\hline 2.2 .1 & Facility Mission & $x$ & $x$ & $\mathrm{x}$ & & \\
\hline 2.2 .3 & Pracess Requirements & $\mathrm{x}$ & & & & \\
\hline 2.2 .4 & Tempered Water System Requirements & & $\mathrm{x}$ & & & \\
\hline 2.2 .5 & Process Vents and Exhausis & $\mathrm{x}$ & $\mathbf{x}$ & $x$ & $\mathrm{x}$ & \\
\hline 2.2 .6 & Process Water Conditioning Requirements & & & $x$ & & \\
\hline 2.2 .7 & Process Controls & $x$ & $\mathrm{x}$ & $x$ & & \\
\hline 2.2 .8 & MCO Release from CVDF & $\mathrm{x}$ & & & & \\
\hline 2.2 .10 & Process Conditions of Operation & $x$ & $x$ & & & \\
\hline \multicolumn{7}{|c|}{ Safety Functional Requirements } \\
\hline 3.4 .1 & Confinement & $x$ & $x$ & $x$ & & \\
\hline 3.4 .3 & Criticality Prevention & & & $\mathrm{x}$ & & \\
\hline 3.4 .4 & MCO Thernal Reaction Rrevention & $x$ & $x$ & & $x$ & $\mathrm{x}$ \\
\hline 3.4 .5 & MCo Hydrogen D/D Prevention & $x$ & & & $x$ & $\mathrm{x}$ \\
\hline 3.4 .7 & Natural Phenomena Hazard Mitigation & $x$ & $x$ & & $\mathrm{x}$ & $x$ \\
\hline 3.4 .8 & Worker Safety Hazards Protection & $x$ & $x$ & $\mathrm{x}$ & $x$ & $\mathrm{x}$ \\
\hline 3.5 .1 & Facility and Process Safe Shutdown & $x$ & $x$ & & $\mathrm{x}$ & $x$ \\
\hline 3.5 .2 & Design Basis Events & $x$ & $\mathrm{x}$ & $\mathrm{x}$ & $\mathrm{x}$ & $\mathrm{x}$ \\
\hline 3.5 .3 & Environmental Qualification & $x$ & $x$ & $x$ & $x$ & $\mathrm{x}$ \\
\hline
\end{tabular}


Table 5-2. Required Codes and Standards for the Cold Vacuum Drying Facility Process System Structures, Systems, and Components.

\begin{tabular}{|c|c|c|c|}
\hline Category/application & GS SSCs & SS SSCs & SC SSCs \\
\hline \multirow[t]{2}{*}{$\begin{array}{l}\text { Structural including concrete } \\
\text { and equipment skids }\end{array}$} & $\begin{array}{l}\text { PC-2 (UBC Zone 2B); AISC; } \\
\text { ACI-318; AWS-D1.1 }\end{array}$ & Same as GS & $\begin{array}{l}\text { ANSI-N690; ACI-349; } \\
\text { PC-3 }\end{array}$ \\
\hline & \multicolumn{3}{|c|}{$\begin{array}{l}\text { Guidance on applicable codes and standards is also provided by Performance Category } \\
\text { per DOE-STD-1021 }\end{array}$} \\
\hline Equipment anchorage & PC-2 (DOE-STD-1021-93) & Same as GS & PC-3 (DOE-STD-1021-93) \\
\hline $\begin{array}{l}\text { Process equipment - } \\
\text { vessels and tanks }\end{array}$ & $\begin{array}{l}\text { ASME Code, Section VII; } \\
\text { API; AWWA-D100; } \\
\text { UL-58, }-142\end{array}$ & Same as GS & ASME Code, Section III ${ }^{a}$ \\
\hline $\begin{array}{l}\text { Process equipment - } \\
\text { piping and valves }\end{array}$ & $\begin{array}{l}\text { ANSLAASME B31.1, B31.3, } \\
\text { B31.5, B31.9, B-16 series }\end{array}$ & Same as GS & $\begin{array}{l}\text { ASME Code, Section III"; } \\
\text { ANSI-N278 }\end{array}$ \\
\hline $\begin{array}{l}\text { Process equipment - } \\
\text { pumps and compressors }\end{array}$ & $\begin{array}{l}\text { ANSU/ASME } 373.1 \mathrm{M}, 2 \mathrm{M} ; \\
\text { ASME Code, Section VII;; } \\
\text { Hydraulic Institute Standards; } \\
\text { AWWA; AFBMA }\end{array}$ & Same as GS & ASME Code, Section III \\
\hline $\begin{array}{l}\text { Process equipment - } \\
\text { heat exchangers }\end{array}$ & $\begin{array}{l}\text { ASME Code, Section VIII; } \\
\text { TEMA }\end{array}$ & Same as GS & ASME Code, Section III' \\
\hline $\begin{array}{l}\text { Process equipment - } \\
\text { hoods and ducts }\end{array}$ & $\begin{array}{l}\text { ASHRAE; SMACNA; } \\
\text { ACGIH; ANSI/ASME N509, } \\
\text { N510 }\end{array}$ & Same as GS & Same as GS \\
\hline $\begin{array}{l}\text { Process equipment - } \\
\text { pre- and HEPA filters }\end{array}$ & $\begin{array}{l}\text { ASHRAE-52.68, } \\
\text { ANSUASME N509, N510; } \\
\text { MIL-F-51068C; } \\
\text { ERDA-76-21 }\end{array}$ & Same as GS & Same as GS \\
\hline Electrical & NFPA 70 (NEC); NESC & IEEE-577 & IEEE-603 \\
\hline Instruments and controls & ISA; S5.1,S5.4,S18.1,S20 & Same as GS & IEEE-603 \\
\hline Fire protection - hydrogen & NFPA & Same as GS & Same as GS \\
\hline Industrial hygiene hazards & $\begin{array}{l}\text { OSHA; AICHE Safety } \\
\text { Standards; API Safety } \\
\text { Standards; ACGIH } \\
\text { Requirements }\end{array}$ & Same as GS & Same as GS \\
\hline All applicable equipment & $\begin{array}{l}\text { OSHA; UL; Local and State } \\
\text { Standards; AWS; NEMA; } \\
\text { ASTM; ANSI }\end{array}$ & Same as GS & Same as GS \\
\hline
\end{tabular}

${ }^{8} \mathrm{ASME}$ Section III or provide justification that ASME B31.3 is appropriate for the system being designed.

${ }^{b}$ ANSI-N278 or provide justification that ASME-B-16 series or B-31.3 is appropriate for the system being designed.

$\mathrm{GS}=$ general services.

HEPA = high-efficiency particulate air (filter).

$\mathrm{SC}=\mathbf{s a f e t y}$ class.

SS $=$ safety significant.

SSC = structure, system, and component. 
5.1.1.2 Reliability, Availability and Maintainability. Each process system shall be allocated reliability, availability and maintainability goals associated with meeting the overall facility processing mission goal defined in Section 2.2.1. All system equipment and components shall have a reliability, availability and maintainability goal associated with meeting the overall system goal. Reliability, availability and maintainability goals for systems and components shall be chosen based on the facility maintenance requirements also defined in Section 5.1.3.

5.1.1.3 Instrumentation and Control. The following design requirements shall be applicable to instrumentation and control equipment designs for all systems in Section 5.0.

Local electronic transmitters (for remote indication) shall include local indication, whenever possible. For example for flow indication, a Flow Indicating Transmitter shall be used.

For major electrical equipment a local control station shall be provided. A switch shall be provided to allow for Hand (local on), OFF, and Remote (from the MCS). When this switch is taken out of Remote, a notification shall be provided to the control room.

Engineering units shall be used wherever possible. The use of $0-100 \%$ range indication shall be avoided. The range of equipment shall cover both the expected normal range as well as upset, emergency and faulted if the instrument would be used under these conditions.

Instruments shall have the capability to be calibrated without the need to open the fluid boundary. The use of wells, isolation valves and test ports shall be utilized whenever possible.

Panel design shall consider the likelihood of surface radioactive contamination and water sprays. In location where this possibility exists, the use of watertight enclosures shall be used.

Panels larger than 8 inches in length or height shall utilize hinged door covers. For all instrument racks, the access doors shall be removable.

The use of hardwired interlocks shall be appropriate to the condition being protected against. For the most part MCS interlocks shall be utilized (software interlocks), however, for the protection of personnel or equipment that can result in significant damage, hard interlocks may be used.

Standardization of the selection of instrument and control equipment is critical to maintenance and is cost effective. All common items within the CVDF shall be the same make and model whenever possible.

The need for "emergency off" buttons shall be reviewed, documented and implemented based on the impact to personnel, equipment or program goals. The implementation of this function may be hardwired or performed by the MCS via local switches. For example, the PWC has a requirement for an emergency off switch due to the potential of contaminated water spray, in this case the MCS will be utilized to perform this function. Note that an emergency off button 
performs a different function that the local off control switch, the emergency button shall be a mushroom type switch allowing for rapid activation.

\subsubsection{Safety Functional Requirements}

The general safety functional requirements from Section 3.0 are summarized and listed in Table 5-1. Table 5-1 assigns these safety functional requirements to the appropriate safety systems and components in this section.

All SSCs required to perform the safety functions of these systems shall be classified as either safety-significant or safety-class. The safety classification will require the assignment of design codes and standards and quality assurance requirements commensurate with the classification. The design codes and standards selected for safety SSCs are listed in Table 5-2. Substitutions and/or additions to these selected codes and standards must be accompanied by justification for why the proposed substitution and/or addition can adequately satisfy the functional performance requirements of the SSC. The assigned codes and standards for all safety SSCs will be identified on the equipment list (see Appendix E).

Safety SSCs are composed either safety-significant or safety-class classifications (see Section 3.0 for classifications). The general design requirements listed below are applicable to all safety-significant systems and components:

1. The safety-significant SSCs shall comply with design requirements in WHC-CM-446.

The general design requirements listed below are applicable to all safety-class systems and components:

1. The safety-class systems needed to meet the technical requirements described below shall comply with "Safety Class" in accordance with DOE Order 6430.1A (see Appendix A for applicable section requirements).

2. Safety-class systems must also comply with NRC equivalency requirements in accordance with Appendix B. The main NRC requirements are found in the Institute of Electrical and Electronics Engineers, Inc. (IEEE), Standard 603-1991, Standard Criteria for Safety Systems (IEEE 1991). These systems shall be "class 1E" in accordance with IEEE Standard 603-1991 (IEEE 1991). Although this is a guide, elements of this and other referenced American National Standards Institute and IEEE standards within IEEE Standard 603-1991 (IEEE 1991) shall be followed to the extent applicable. Where applicability evaluations are required, full documentation shall be provided. 
HNF-SD-SNF-DRD-002 REV 1

\subsubsection{Testing, Surveillance and Maintenance Requirements}

All equipment shall be designed to optimize testing, surveillance and maintenance to maximize system and component reliability, availability and maintainability goals established (see Section 5.1.1.2 for goals) and minimize operational staff workloads. As a goal, general services process equipment shall avoid or minimize regularly scheduled tests, surveillances and maintenance activities. Safety equipment regularly scheduled testing, surveillance, and maintenance shall be designed for minimum impact on facility availability and staffing requirements.

The safety-significant systems or components shall be designed for testing, surveillance, and maintenance in accordance with higher reliability goals as identified in each systems safety design requirements. The safety-significant systems components shall be under administrative control for all testing, surveillance, and maintenance activities. All activities shall be performed under controlled procedures.

The safety-class systems shall be designed for testing, surveillance, and maintenance in accordance with IEEE Standard 603-1991 (IEEE 1991). The safety-class systems shall be under administrative control for all testing, surveillance, and maintenance activities. All activities shall be performed under controlled procedures.

5.1.3.1 Testing. Testing features shall be designed to implement testing requirements. Functional performance criteria for the systems shall be identified and tested on a periodic basis to ensure operability of systems and components. Safety system and component functions and minimum operability criteria (e.g., helium tank pressure, helium minimum flow rates, sensor calibration, trip signal operation) shall be identified and tested on a regular schedule. All testing shall be accomplished between MCO processing cycles to the maximum extent possible, and shall have minimum impact on processing availability. Only standard approved and controlled testing procedures and equipment shall be used.

The safety components shall be tested for integrity and reliability of the defined safety function. At a minimum, the SCI\&C system, SCHe purge system and safety-class VPS isolation components shall be designed to be functionally tested for actuation given a simulated process condition input. The actuation signal to each safety component shall be verified. VPS isolation shall be tested for adequate component operation. SCHe flow to the MCO port connections for both line break and line intact (venting) scenarios shall be tested for adequate system component, pressure, and flow operation.

5.1.3.2 Surveillance. System design shall incorporate features for verifying system operability. Operability will be verified by surveillance of the system's operability status and component states (e.g., valve position lineup, helium tank supply pressure, system alarms) before enabling the system for each MCO process cycle. The system shall require additional periodical surveillance if required to be operational for an extended period of time beyond one normal processing cycle (if an $\mathrm{MCO}$ is left in standby before shipping). 
5.1.3.3 Maintenance. There shall be no regularly scheduled facility shutdowns for maintenance. Regularly scheduled maintenance activities shall be avoided in the design. The system maintenance activities shall be limited to maintenance due to failures. Where maintenance may be required, the system design shall incorporate features and requirements for ease of maintenance and replacement of parts to maintain high system availability. To the maximum extent possible, the design shall enhance the isolation capabilities of major components and energy sources in order to simplify lock and tag requirements. Additional maintenance activities and procedures may be scheduled if system testing, surveillance, or maintenance identifies additional maintenance needs. All maintenance shall be performed under controlled procedures using approved (Quality Assurance qualified) equipment and materials. Only spare parts meeting design criteria shall be procured and used.

\subsubsection{Environmental Qualification}

All general services components shall be designed to operate under normal environmental conditions. The normal environmental conditions are listed in Table 5-3.

All safety components shall be designed to function under worst-case internal and external environmental conditions. These conditions are composed of design basis events and process upset event plant conditions identified in Section 3.5.2 and the associated internal and external environmental conditions listed in Table 5-3. Safety detection or protection shall be provided where the design cannot guard against these impacts. The design shall mitigate those conditions that represent a potential common-mode failure of the safety function and documentation shall be provided for those mitigation features.

\subsubsection{Seismic Qualification}

All equipment shall be assigned either to seismic PC-2 for general services and safety-significant functions or to PC-3 for safety-class functions in accordance with the seismic design requirements in Section 3.3.8, Section 3.4.7 and Tables 3-6 and 3-7.

Safety-class seismic sensors and actuation relays shall be provided to actuate the $\mathrm{SCHe}$ system and VPS isolation components to put all MCOs in process into a safe shutdown condition. All equipment, from the seismic sensors to the SCHe and VPS isolation system, required to achieve a safe shutdown will be seismically qualified to perform the safe shutdown function under the design basis seismic PC-3 criteria (Tallman 1996), induced plant conditions identified in Section 3.5.2, and environmental conditions identified in Table 3-10. 
Table 5-3. Environmental Qualification Requirements for General Services, Safety-Significant and Safety-Class Structures, Systems, and Components.

\begin{tabular}{|c|c|c|c|c|c|c|c|c|c|}
\hline \multirow{3}{*}{ No. } & \multirow{3}{*}{ Plant state } & \multicolumn{8}{|c|}{ Service conditions } \\
\hline & & \multicolumn{4}{|c|}{ External } & \multirow{2}{*}{$\begin{array}{c}\text { Internal } \\
\text { Contamination }\end{array}$} & \multirow{2}{*}{ Radiation } & \multirow{2}{*}{ Vibration } & \multirow{2}{*}{ Duty cycle } \\
\hline & & Temperature & Pressure & Humidity & Contamination & & & & \\
\hline 1 & Normal conditions & $40^{\circ} \mathrm{F}-130^{\circ} \mathrm{F}$ & Ambient & $0 \%-100 \%$ & Dirt/dust & System Specific & $\begin{array}{l}\text { System } \\
\text { location } \\
\text { specific }\end{array}$ & $\begin{array}{l}\text { Frequency } \\
\text { (TBD) }\end{array}$ & Time in use \\
\hline 2 & Upset conditions & $\mathrm{NC}$ & $\mathrm{NC}$ & $\mathrm{NC}$ & $\mathrm{NC}$ & $\mathrm{NC}$ & $\mathrm{NC}$ & NA & NA \\
\hline 3 & Contamination release & $\mathrm{NC}$ & $\mathrm{NC}$ & $\mathrm{NC}$ & $\begin{array}{l}\text { Dirt/dust } \\
\text { radiation }\end{array}$ & $\begin{array}{l}\text { Dirt/dust } \\
\text { radiation }\end{array}$ & $\mathrm{NC}$ & NA & NA \\
\hline 4 & $\begin{array}{l}\text { Loss of power, cooling, } \\
\text { or HVAC }\end{array}$ & $130^{\circ} \mathrm{F}$ & $\mathrm{NC}$ & $\mathrm{NC}$ & $\mathrm{NC}$ & $\mathrm{NC}$ & NC & NA & NA \\
\hline 5 & $\begin{array}{l}\text { Process equipment } \\
\text { explosion }\end{array}$ & $\mathrm{NC}$ & NC & $\mathrm{NC}$ & $\mathrm{NC}$ & $\mathrm{NC}$ & $\mathrm{NC}$ & NA & NA \\
\hline 6 & Fire & $\mathrm{NC}$ & TBD & $100 \%{ }^{2}$ & Smoke & Smoke & $\mathrm{NC}$ & NA & NA \\
\hline 7 & Seismic event & $130^{\circ} \mathrm{F}$ & NC & $\mathrm{NC}$ & NC & $\mathrm{NC}$ & $\mathrm{NC}$ & NA & NA \\
\hline 8 & Tornado and high winds & $130^{\circ} \mathrm{F}$ & $\mathrm{NC}$ & $\mathrm{NC}$ & $\mathrm{NC}$ & $\mathrm{NC}$ & $\mathrm{NC}$ & NA & NA \\
\hline 9 & Floods & $130^{\circ} \mathrm{F}$ & $\mathrm{NC}$ & $\mathrm{NC}$ & $\mathrm{NC}$ & $\mathrm{NC}$ & $\mathrm{NC}$ & NA & NA \\
\hline
\end{tabular}

aSprinklers are actuated and all equipment is deluged with water.

HVAC = heating, ventilating, and air conditioning.

$\mathrm{NA}=$ not applicable.

$\mathrm{NC}=$ normal conditions

$\mathrm{TBD}=$ to be determined. 
All equipment within the process bays with the potential, because of seismic-induced failure, of preventing safety-class SSCs from performing safety-class functions shall be anchored for the design basis seismic PC-3 criteria in accordance with WHC-SD-GN-DGS-30006, Guidelines for Assessing the Seismic Adequacy of Existing Performance Category Equipment at the Hanford Site (Conrads 1996). Seismic design requirements for all SSCs shall be assigned and documented in the equipment list (see Appendix E).

\subsubsection{Human Factors}

Human factors consideration in the design of $\mathrm{DOE}$ facilities is required in $\mathrm{DOE}$ Order 6430.1A, Section 1300-12.4 (see Appendix A for applicable requirements). DOE has a draft standard, "Human Engineering Design Criteria, Volume I," that shall be used as a guideline for evaluating human factors considerations of the CVDF design. In addition, NRC equivalency (see Appendix B) requires that NUREG-0700, Human System Interface Design Review Guidelines (NRC 1995), and NUREG-0800, Standard Review Plan, Section 18.1, "Human Factors Engineering, Control Room" (NRC 1984), be reviewed for additional applicable requirements above the DOE guidelines. Application of these guidelines shall be documented for the appropriate human factors interfaces (man-machine interfaces) of the safety-class SSCs. These include, but are not limited to, the following interfaces and activities:

- Operations interfaces (operator activities and task analysis)

- Process water tank room operations review

- Process bay operations review

- Control interfaces for normal, upset, and emergency or faulted conditions for

- Control room interfaces

- Process bay local controls and panels

- Testing, surveillance, and maintenance activities.

\subsection{VACUUM AND PURGING SYSTEM DESIGN REQUIREMENTS}

\subsubsection{Location, Boundaries and Interfaces}

5.2.1.1 Location. There shall be four separate VPSs and process connection components, one for each process bay, mounted on an equipment skid located under the mezzanine in each bay. All necessary VPS equipment shall be located either on the VPS skid or process connection lines to the MCO. 


\subsubsection{Boundaries and Interfaces.}

a. Each system shall interface with the MCS and SCI\&C system for instrumentation and control.

b. Each VPS safety-class isolation function shall receive signals from two SCI\&C output trains of controls, train A and train B (see IEEE Standard 603-1991 requirements [IEEE 1991]).

c. Each system shall use non-safety control power supplied by the facility UPS. Proper isolation from the effects of power transients and failures shall be provided such that the safety functions can still be accomplished under power loss or transient conditions.

\subsubsection{Process Functional Requirements}

The function of the VPS is to first assist in the removal of the bulk water from the within the $\mathrm{MCO}$, and second, to dry the MCO contents under vacuum and inert gas (helium) purging using a cycle of evacuation and inert gas backfill/purge stages. The final product will be a dried MCO that has been backfilled with inert gas. The VPS shall consist of a single vacuum pumping stage, a helium gas recirculation stage, valves, traps, filters, instrumentation, and ducting that will achieve and maintain the required operating pressures in the $\mathrm{MCO}$.

The VPS shall support four modes of operation;

1. Bulk water removal where inert gas shall be supplied while water is withdrawn from the MCO

2. Vacuum Pump-down

3. Inert gas purge

4. MCO Acceptance Testing (Pressure Rebound and Shipping Acceptance).

\subsubsection{Safety Functional Requirements}

The following are the safety function requirements for VPS summarized from Section 3.0, Table 3-7. See Section 3 for further descriptions of these safety functions.

- Primary Confinement (Contaminated effluents from $\mathrm{MCO}$ )

- Radiation Protection (ALARA from contaminated effluents) 
- MCO Isolation (Prevention of nunaway corrosion reaction and/or hydrogen deflagration/detonation)

- NPH Mitigation (Seismic)

- Worker Safety Hazards Protection (Industrial Safety and Industrial Hygiene).

The VPS piping and components that form the leaktight pressure boundary are defined as the safety-significant primary confinement boundary for confinement of contaminated effluents from the MCO. The design of these components shall minimze holdup and accumulation of contaminants to reduce the radiation exposure of the system to ALARA. The system and components shall provide protection against industrial hazards for protection of the workers. These components are relied upon during a seismic event to maintain boundary integrity against release for protection of the workers (PC-2).

MCO isolation shall provide control valves and/or other isolation features to control the flow of process effluents to and from the $\mathrm{MCO}$ and to isolate the process from the MCO. This protection function consists of the components required to isolate the $\mathrm{MCO}$ from the process equipment and the instrumentation and controls to monitor the isolation condition. This is a safety-class function that is required to be functional before and after a seismic event (PC-3).

\subsubsection{Process Performance Requirements}

Removal of MCO bulk water shall meet the following requirements:

a. Water from the MCO shall be transferred through a drain pipe system to a collection tank/purification system shared by all the process bays. The water shall be drawn from the bottom of the MCO through the MCO draw tube. A screen will prevent particulates larger than $2 \mathrm{~mm}$ ( $0.8 \mathrm{in}$.) from exiting the $\mathrm{MCO}$.

b. The drain line shall be capable of being evacuated. The vacuum shall be sufficient to draw liquid from the bottom of the MCO to the highest point in the PWC system.

c. The helium system connections to the MCO shall be used to pressurize the head space above the water in the $\mathrm{MCO}$ as it is transferred.

d. There shall be an isolation valve in the drain line near the $\mathrm{MCO}$. This valve shall be open during water transfer and closed during the drying process. The valve must seal well enough that leakage through it will not prevent the $\mathrm{MCO}$ from attaining its ultimate vacuum requirement.

e. The MCO plug valve operator that is exposed to contaminated water flow shall be injected with deionized water into the operator body while the purge gas flows 
immediately after the last water has been drawn from the MCO. The rinse water shall clean the drain line and be collected in the PWC system.

The vacuum pump down and helium injection shall meet the following requirements.

a. The VPS shall remove gas species (volumetric, off-gassing, residual free water, water-fuel reaction products and in-leakage) from the $\mathrm{MCO}$ so that the contents of the $\mathrm{MCO}$ are dried until a vacuum $<67 \mathrm{~Pa}(0.5$ torr) is achieved and until a one hour pressure rise test started when the pressure is $<67 \mathrm{~Pa}(0.5$ torr) does not result in a final pressure above $400 \mathrm{~Pa}$ ( 3.0 torr). The system shall be sized to achieve these results in 24 hrs or less.

b. The system shall be capable of injecting helium into the $\mathrm{MCO}$ periodically so that an evacuation-purge cycle can be operated.

c. The VPS shall have the capability of pumping down the MCO to operating basis pressure level within a period not to exceed 24 hours with the gas loads at the average power condition. This condition assumes that the VPS and MCO are leaktight to the MCO operating level basis $\left(10 \mathrm{~Pa} / \mathrm{cm}^{3} / \mathrm{sec}[1 \times \mathrm{E}-4 \mathrm{~atm} . \mathrm{cc} / \mathrm{sec}]\right)$.

d. All valves shall have remotely activated operators. All valves shall fail to a fail-safe position upon loss of control air, control signal or electric power. The valves may have elastomer seals. This requirement is dictated due to the low vacuum requirements. No Code requirements are stipulated for the vacuum valves.

e. The VPS shall be designed to assist in the helium leak checking of the MCO following installation of the top shield.

f. The VPS shall be designed to preclude backstreaming of oil into the MCO and also to prevent oil contamination of downstream equipment.

g. Gas drawn from the MCO shall be filtered as close to the MCO as can be reasonably configured to minimize the migration of radioactive dust particles through the VPS. Water in the pump exhaust and circulating inert gas stream shall be condensed. The water shall be directed to the PWC system.

h. Water collected from the condenser shall be pumped into the PWC system.

i. The inert gas purge controller shall be capable of throttling the vacuum pump such that the pressure inside the $\mathrm{MCO}$ will be maintained at $0.7 \mathrm{kPa}$ ( 5 torr) or more to prevent freezing of bulk water during initial pumpdown. At this pressure the water in the $\mathrm{MCO}$ will not freeze as the equilibrium vapor pressure of water at $0^{\circ} \mathrm{C}\left(32^{\circ} \mathrm{F}\right)$ is $0.6 \mathrm{kPa}$ (4.56 torr). 
j. After the bulk water is removed the pumping system shall have the capability of achieving a pressure of $1.3 \times 10^{1} \mathrm{~Pa}\left(1 \times 10^{-1}\right.$ torr $)$ for final water vapor removal.

k. The VPS shall control the introduction of inert gas for backfilling the MCO (normal shutdown) and in case of off normal (non-emergency) shutdown conditions.

The Gas Monitoring and Analysis function shall be designed to meet the following performance requirements:

a. The Gas Monitoring and Analysis system shall sense critical parameters of the MCO and forward quantitative values to the control system. The vacuum system instrumentation and control features shall interface with this system.

b. The pressure monitoring system shall consist of a series of total pressure gauges to measure pressure from $101 \mathrm{kPa}$ (one atmosphere) down to $0.1 \mathrm{~Pa}(1 \times \mathrm{E}-03$ torr). This range is usually monitored by a number of sensors optimized for a set pressure range. The instrumentation controller will automatically select the proper sensor for readout depending on the pressure in the vacuum system.

c. A residual gas monitoring system shall be provided that will measure the concentration of hydrogen and water vapor gas species and shall determine the gas concentration to $1 \mathrm{ppm}$. A residual gas analyzers based upon quadrupole or mass sector design shall measure the gas species partial pressure over the range of 1 to 100 atomic mass units minimum and detect partial pressures to $1 \times 10^{-4} \mathrm{~Pa}(1 \times \mathrm{E}-6$ torr $)$.

The instrumentation and gas analyzers shall be continuously on line. Parameters to be sensed include the following:

a. Total vacuum pressure at the $\mathrm{MCO}$ and vacuum system locations

b. Partial pressures of residual gases in the $\mathrm{MCO}$

c. Hydrogen, Tritium and fission gas (principally Krypton-85) levels.

d. The Gas Monitoring and Analysis system shall have sufficient gauging to provide interlock functions and determine system performance.

e. The design shall provide control, monitoring, and alarm schemes, including interlocks, suitable alarm setpoints, or other means to ensure protection of personnel, test assembly, and equipment in the event of utilities failure, equipment malfunction, and operator error. The control logic shall address normal and abnormal operation.

f. For detecting air inleakage, total pressure sensors shall be installed on the VPS leading to the MCO. These sensors shall detect an increase in total pressure from the normal operating pressure and initiate an alarm when a preset level is reached. 
g. The gas analyzers shall read out the partial pressures of the gasses in the MCO at a display at the control panel. The ratios of oxygen, nitrogen, and argon shall determine the presence of MCO in-leakage and at preset levels, an alarm shall sound.

The performance requirements for the $50^{\circ} \mathrm{C}$ pressure rebound test and the $75^{\circ} \mathrm{C}$ shipping acceptance test are listed below:

a. The acceptance criterion for the $50^{\circ} \mathrm{C}$ pressure rebound test shall be that the $\mathrm{MCO}$ pressure shall increase less than 3 torr in one hour from the base pressure of 0.5 torr or less.

b. The acceptance criterion for the $75^{\circ} \mathrm{C}$ shipping acceptance test shall be that the $\mathrm{MCO}$ pressure shall increase less than $0.2 \mathrm{psi}$ per hour from the nominal base pressure of $1 \mathrm{~atm}$. The pressurization rate shall be averaged over a 12-hour test period.

\subsubsection{Safety Performance Requirements}

Each system shall interface with the facility MCS for non-safety instrumentation and control functions operation from the control room. The MCS normal control operation shall not degrade or prevent the safety function operation.

Safety-significant primary confinement shall meet the following requirements.

a. Primary confinement boundary shall be designed to be leaktight against release of airborne and liquid effluents. Leaktightness criteria for safety functions are the same as required for processing (see Section 5.2.2).

b. The piping and components that come in contact with contaminated effluents from the MCO shall be designed to minimize holdup and buildup of contamination and meet ALARA design criteria in Section 3.3.2 and 7.3.

Safety-Class Isolation shall meet the following performance requirements.

a. The safety-class isolation equipment shall be part of the VPS operation and shall be operable during all times the VPS is connected to the MCO and the MCO port valves are open.

The VPS shall use safety-class isolation valves to isolate the VPS components from the $\mathrm{MCO}$ and electrical control lockout features to prevent the valves from actuating open. All components and instrumentation required to maintain the isolation are designated safety class. 
The safety-class isolation components and instruments shall be located on the process connection lines off of the skid. These components shall be physically protected from potential damage and impact.

b. Isolation valves shall be capable of providing reliable, leaktight (see Section 5.2 .2 for leak criteria) operation, including fail-safe operation upon loss of control signal or instrument air.

c. Isolation valves shall, upon receipt of an actuation signal from the SCI\&C system, go closed and lock out all other non-safety control signals and functions until reset by the SCI\&C system or through manual override by the operator. Non-safety operation control signals from the MCS must not affect or degrade the safety-class operation.

d. Instrumentation and Control Instrumentation shall be provided to indicate and alarm proper VPS isolation. Both a remote means of valve position indication and alarm to the MCS and control room and a local, manual, means of valve position indication shall be provided. The local manual valve position indication shall require no power for operation.

e. A single point failure analysis shall be performed and documented in accordance with IEEE-603.

5.2.5.1 Operational Support Requirements. The system shall be designed to the following operational support requirements.

- The system shall be designed to not require safety-class support systems such as electric power, instrument air, or any other support function.

- Fail-safe criteria shall be applied throughout the design of all safety-class systems. A loss of power or control air shall result in a safe shutdown for example.

- Electrical isolation shall be provided to separate the safety system from non-safety systems. This would include all interfacing with the MCS and the non-safety power source.

- The safety components safety functions shall not be prevented by the potential effects of contaminated instrument.

5.2.5.2 Seismic Requirements. All equipment required to perform the safety-significant primary confinement function shall be seismically qualified to PC-2 criteria. All equipment required to perform the safety-class VPS isolation function shall be seismically qualified to PC-3 criteria to perform its safety function following a design basis seismic event. A listing of these assignments is provided in Table $5-4$. 
Table 5-4. Vacuum Purge System Design Requirements.

\begin{tabular}{|l|c|c|c|}
\hline \multicolumn{1}{|c|}{ Components } & $\begin{array}{c}\text { Safety } \\
\text { classification. }\end{array}$ & $\begin{array}{c}\text { NPH } \\
\text { performance } \\
\text { category }\end{array}$ & $\begin{array}{c}\text { Environmental } \\
\text { qualification } \\
\text { (see Table 5-3) }\end{array}$ \\
\hline Vacuum pump & SS & PC-2 & 1 \\
\hline Condenser and tank & SS & PC-2 & 1 \\
\hline Recycle pump & SS & PC-2 & 1 \\
\hline MCO Isolation piping and valves & SC & PC-3 & 1 through 9 \\
\hline Piping and valves & SS & PC-2 & 1 \\
\hline Gas analysis system & GS & PC-2 & 1 \\
\hline Instrumentation and control & GS & PC-2 & 1 \\
\hline Support structure & SS & PC-2 & 1 \\
\hline
\end{tabular}

${ }^{1}$ This equipment is PC-3 if its failure can prevent the proper operation of safety-class isolation functions.

${ }^{2}$ Safety-class MCO isolation piping is from the MCO up to and including the first process isolation valves and all other valves relied upon for $\mathrm{MCO}$ and water isolation.

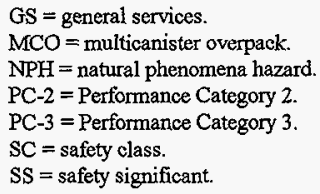

5.2.5.3 Environmental Qualification. All safety components shall be designed to function under worst-case internal and external environmental conditions. These conditions are composed of faulted and process upset event plant conditions identified in Section 3.5.2 and the associated internal and external environmental conditions listed in Table 5-3. The design shall mitigate those conditions that represent a potential common-mode failure of safety systems and documentation shall be provided for those mitigation features.

\subsubsection{Codes and Standards}

The codes and standards applicable to the design of SSCs are listed in Table 5-2. 


\subsection{TEMPERED WATER SYSTEM DESIGN REQUIREMENTS}

\subsubsection{Location, Boundaries and Interfaces}

Cask annulus water protection features shall ensure thermal protection of the fuel.

5.3.1.1 Location. The cask annulus is connected from the TWS on the VPS skid to the MCO. Connections are made through a port on the bottom of the cask and through the seal ring on the top of the MCO. Cask annulus water protection features are located on the TWS connections to the $\mathrm{MCO}$.

\subsubsection{Boundaries and Interfaces.}

a. The boundaries of the cask annulus water protection features are at the circulation lines that connect to the bottom of the cask and the top of the cask through the cask annulus seal ring.

b. Each system shall interface with the MCS and SCI\&C system for instrumentation and control.

\subsubsection{Process Functional Requirements}

a. The function of the TWS is to maintain the MCO at the proper operating temperatures during all stages of the MCO drying process. This includes heating the MCO during vacuum drying and cooling the $\mathrm{MCO}$ after vacuum drying.

b. The TWS shall be required to pump water at various design temperatures through the annular space between the MCO and cask. The seal ring forms the upper pressure boundary of the cask-MCO annulus and allows the circulation of tempered water to and from the annulus.

\subsubsection{Safety Functional Requirements}

The following are the safety function requirements for TWS summarized from Section 3.0 , Table 3-7. See Section 3 for further descriptions of these safety functions.

- Primary Confinement (Contaminated effluents from cask annulus water)

- Radiation Protection (ALARA from contaminated effluents)

- Cask Annulus Water Protection (Prevention of runaway corrosion reaction)

- NPH Mitigation (Seismic)

- Worker Safety Hazards Protection (Industrial Safety and Industrial Hygiene). 
The seal ring provides primary confinement protection features to ensure confinement of liquid and gaseous effluents from the TWS. The seal ring also forms a boundary of the cask annulus water and must perform part of the cask annulus water protection safety function.

\subsubsection{Process Performance Requirements}

a. The required flow rate of the TWS shall be a minimum of $76 \mathrm{~L} / \min (20 \mathrm{gpm})$ and shall have a design gauge pressure of $138 \mathrm{kPa}\left(20 \mathrm{lb} / \mathrm{in}^{2}\right)$, with a maximum allowable gauge pressure of $172 \mathrm{kPa}\left(25 \mathrm{lb} / \mathrm{in}^{2}\right)$ in the cask-MCO annular space.

b. During vacuum drying, the TWS shall be able to heat the $M C O$ and maintain it at a temperature of approximately $50^{\circ} \mathrm{C}\left(122^{\circ} \mathrm{F}\right)$ for a continuous period of not more than two days per drying operation to assist in the removal of residual water from the MCO.

c. After vacuum drying of the MCO, the TWS shall be required to cool the $\mathrm{MCO}$ and Cask down to $15^{\circ} \mathrm{C}\left(59^{\circ} \mathrm{F}\right)$, the required temperature for shipping.

d. The TWS shall have the capability to heat the cask-MCO assemble to $75^{\circ} \mathrm{C}\left(167^{\circ} \mathrm{F}\right)$ for the shipping acceptance test. The design temperature range is specified at $10^{\circ} \mathrm{C}$ to $85^{\circ} \mathrm{C}\left(50^{\circ} \mathrm{F}\right.$ to $\left.185^{\circ} \mathrm{F}\right)$.

e. The TWS shall be required to interface with the MCS to allow for computer control of MCO heating and cooling during all stages of the drying operation.

f. Water heating shall be accomplished with an electric heater. Heater power shall be controlled with an SCR. Water cooling shall be accomplished with a heat exchanger that transfers heat to a central chilled water system. Deionized water shall be used for the make-up water.

g. Each cask will arrive with water in the annulus. Addition of the cask water to the system will require periodic release of water to maintain the system fill level. The TWS drain shall lead to the PWC system. The system shall have a method of draining the cask without draining the system. Either a pump or gas pressure may be used to move the water out of the cask.

h. There shall be two process system connections to the cask. These shall be water tight quick connect fittings that mate with fittings provided on the cask. There shall be a valve/pressure gauge arrangement in the upper connection to allow for measurement and bleed off of the cask pressure when the connection is made.

i. Water in the system may become slightly contaminated. There shall be provision for periodic sampling the water and flushing of the system with deionized water. 
The following are the seal ring performance requirements.

a. The ring shall fit on the cask and be held in place with bolts using the bolt holes that are used for attaching the cask lid to the cask.

b. The ring shall include a seal that retains water in the annulus while it is being circulated through the annulus with a maximum gauge pressure of $172 \mathrm{kPa}\left(25 \mathrm{lbf} / \mathrm{in}^{2}\right)$.

c. The center of the seal ring shall be open to allow process system connection access to the ports on the top of the MCO. The seal ring thickness shall be sized to resist the uplift load due to the circulating water within the Cask annulus.

d. The seal ring is not required to provide any shielding for radiation streaming from the cask annulus.

\subsubsection{Safety Performance Requirements}

Each system shall interface with the facility MCS for non-safety instrumentation and control functions operation from the control room. The MCS normal control operation shall not degrade or prevent the safety function operation.

Safety-significant primary confinement shall meet the following requirements.

a. Primary confinement boundary shall be designed to be leaktight against release of airborne and liquid effluents. Leaktightness criteria for safety functions are the same as required for processing (see Section 5.2.2).

b. The piping and components that come in contact with contaminated effluents from the MCO shall be designed to minimize holdup and buildup of contamination and meet ALARA design criteria in Section 3.3.2 and 7.3.

The following are the design requirements for the cask annulus water protection function. The equipment shall be part of the TWS operation and shall be operable during all times the TWS is in service to the cask annulus.

a. The cask annulus water level to the top of the cask must be protected to ensure proper heat conduction from the MCO to the cask for thermal protection of the fuel. This protection function consists of the components required to maintain the water level to the top of the cask annulus ring and the instrumentation and controls to monitor the water level.

b. Instruments are required to be redundant. 
c. The TWS shall use a "stand pipe" configuration from the seal ring assembly to maintain water level in the annulus. An anti-siphon system shall be used. All components required to maintain the water level are designated safety class.

d. The cask drain port spool piece shall be designed such that failures to the TWS would preclude draining of the cask annulus space. Sufficient means shall be included to verify water remains in the annulus space after an upset condition has occurred. The connection of the Cask Drain Port shall be compatible with the quick connection fitting contained in the cask and be capable of remote connection for ALARA concerns. The Cask Drain Port, Safety Class Spool Piece shall be considered as part of the Seal Ring/Process Hood package and may be supported from the process hood..

e. A manual means to fill and vent the cask annulus with water after a DBA shall be provided. As a suggestion, a pair of quick disconnects, one for the vent and the other for filling the annulus may be used. This would require that "special tools" be provided for operations.

f. Instrumentation shall be provided to indicate and alarm proper water level at the top of the cask annulus seal ring. Both a remote means of water level indication and alarm to the MCS and control room and a local, manual, means of water indication shall be provided. The local manual water level indication shall require no power for operation.

g. A single point failure analysis shall be performed and documented in accordance with IEEE-603.

5.3.5.1 Operational Support Requirements. The system shall be designed to the following operational support requirements.

- The system shall be designed to not require safety-class support systems such as electric power, instrument air, or any other support function.

- Fail-safe criteria shall be applied throughout the design of all safety-class systems. A loss of power or control air shall result in a safe shutdown for example.

- Electrical isolation shall be provided to separate the safety system from non-safety systems. This would include all interfacing with the MCS and the non-safety power source.

- The safety components safety functions shall not be prevented by the potential effects of contaminated instrument.

5.3.5.2 Seismic Requirements. All equipment required to perform the safety-significant primary confinement function shall be seismically qualified to PC-2 criteria. All equipment required to perform the safety-class VPS isolation function shall be seismically qualified to PC-3 criteria to 
perform its safety function following a design basis seismic event. A listing of these assignments is provided in Table $5-5$.

Table 5-5. Tempered Water System Design Requirements.

\begin{tabular}{|l|c|c|c|}
\hline \multicolumn{1}{|c|}{ Components } & $\begin{array}{c}\text { Safety } \\
\text { classification }\end{array}$ & $\begin{array}{c}\text { NPH } \\
\text { performance } \\
\text { category }^{\prime}\end{array}$ & $\begin{array}{c}\text { Environmental } \\
\text { qualification } \\
\text { (see Table 5-3) }\end{array}$ \\
\hline Pump & SS & PC-2 & 1 \\
\hline Tank & SS & PC-2 & 1 \\
\hline Heater & SS & PC-2 & 1 \\
\hline SC cask connections and standpipe & SC & PC-3 & 1 through 9 \\
\hline Piping and valves & SS & PC-2 & 1 \\
\hline Chiller/heat exchanger & SS & PC-2 & 1 \\
\hline Instrumentation and control & GS & PC-2 & 1 \\
\hline Support structure & SS & PC-2 & 1 \\
\hline
\end{tabular}

${ }^{2}$ This equipment is $\mathrm{PC}-3$ if its failure can prevent the proper operation of safety-class isolation functions.

${ }^{2}$ Safety-class cask annulus connection piping is from the cask connection up to and including the end of the standpipe that prevents water from being drained from the annulus.

GS $=$ general services.

$\mathrm{NPH}=$ natural phenomena hazard.

PC-2 = Performance Category 2.

PC-3 = Performance Category 3.

$\mathrm{SC}=$ safety class.

$\mathrm{SS}=$ safety significant.

The connection from TWS to the cask shall be safety-class to prevent leakage in case of a seismic event. Note that Duke Engineering and Services Hanford has the responsibility to meet seismic criteria for the quick-disconnect connecting the TWS to the cask. Design input for the stand pipe is required to perform the analysis, and this responsibility rests on the Design Agent.

5.3.5.3 Environmental Qualification. All safety components shall be designed to function under worst-case internal and external environmental conditions. These conditions are composed of faulted and process upset event plant conditions identified in Section 3.5.2 and the associated internal and external environmental conditions listed in Table 5-3. The design shall mitigate those conditions that represent a potential common-mode failure of safety systems and documentation shall be provided for those mitigation features. 
HNF-SD-SNF-DRD-002 REV 1

\subsubsection{Codes and Standards}

The codes and standards applicable to the design of SSCs are listed in Table 5-2.

\subsection{PROCESS WATER CONDITIONING SYSTEM DESIGN REQUIREMENTS}

\subsubsection{Location, Boundaries and Interfaces}

5.4.1.1 Location. There shall be one PWC system mounted on an equipment skid located in the process water tank room. All necessary PWC system equipment shall be located either on the PWC system skid or in the process water tank room.

\subsubsection{Boundaries and interfaces.}

a. PWC system shall receive actuation signals from and/or input to the MCS.

b. The PWC system shall receive all contaminated water from each of the four process bays and floor drain system.

c. PWC system shall use non-safety control power supplied by the facility UPS.

\subsubsection{Process Functional Requirements}

The primary function of the PWC system is to provide a local point of collection for process liquids in each of the six process bays. Liquids will be pumped from the PWC to a $19,000 \mathrm{~L}$ (5,000 gal) central liquid holding tank. This liquid will then be transported by tanker to the $\mathrm{KW}$ Basin IWTS for final treatment. There shall be provision for determining that the purified water is acceptable for storage in a large (non-critically-safe) tank. There shall be sampling/analysis to determine that the water is acceptable for shipment.

\subsubsection{Safety Functional Requirements}

The following are the safety function requirements for PWC system summarized from Section 3.0, Table 3-7. See Section 3 for further descriptions of these safety functions.

- Primary Confinement (Contaminated effluents from cask-MCO water)

- Radiation Protection (ALARA from contaminated effluents)

- Criticality Control

- NPH Mitigation (Seismic)

- Worker Safety Hazards Protection (Industrial Safety and Industrial Hygiene) 


\subsubsection{Process Performance Requirements}

a. The PWC shall be required to provide pumping and filtration capability for all process liquids generated during vacuum drying of the $\mathrm{MCO}$. These liquids will primarily include pool water drained from the $\mathrm{MCO}$, and tempered water used by the TWS to heat and cool the MCO.

b. The PWC shall provide capacity for liquid generated by the vacuum drying of one MCO. The inlet line to the PWC receiving tank shall be equipped with a flow meter and totalizer to track the volume of liquid that is pumped to the PWC.

c. Air-operated, computer-controlled valves shall control flow of liquid within the PWC system.

d. The pump used to transfer liquid shall be interlocked to prevent overfilling of the storage or transfer tanks.

e. The PWC tank shall be vented through a HEPA filter to the facility HVAC exhaust.

f. The PWC shall be required to interface with the CVDF MCS to allow for computer control of liquid handling to and from the PWC.

g. There shall be no safety class criticality instrumentation and control requirements. All criticality control is being accomplished by design geometry control of the receiver tanks, ion exchange modules (IXMs) and filter. This system is composed of SC components (Receiver Tanks, IXMs, and a filter). There are no active design features for criticality control.

\subsubsection{Process Water Conditioning.}

a. There shall be a system of pumps, filters, and ion exchangers that shall remove the TRU materials (at a minimum) from the process water.

b. Water from the raw PWC system shall be processed by the filtration/ion exchange process.

c. The purified water quality shall be acceptable for shipment to KW-IWTS by Tanker Truck assuming low specific activity quantities.

d. The filter/ion exchange units shall be based on $\mathrm{K}$ Basins experience operating the basin water systems.

\subsubsection{Ion Exchange Module Design Requirements.}

a. The IXMs shall connect to the facility piping with hoses and quick disconnects. 
The design criteria and values for pressure, temperature, and flow for the current $\mathrm{K}$ Basin design can be found in the Procurement Specification for IXMs (WHC-S-0142).

b. There shall be two (2) IXMs for processing the CVDF process water and shall be capable of removing ${ }^{137} \mathrm{Cs}$ and ${ }^{90} \mathrm{Sr}$ ions from the CVDF process water.

c. The modules shall use mixed bed resins to maintain deionized low conductivity water to be returned to the $\mathrm{KW}$ Basin. Special resins shall be used to control pH, e.g., an anion resin to raise the $\mathrm{pH}$, or specifically to remove cesium, e.g., zeolite.

d. The modules shall be designed based upon current $\mathrm{K}$ Basin design which have specified conditions of $606 \mathrm{~L} / \mathrm{min}(160 \mathrm{gal} / \mathrm{min})$, maximum allowable working pressure of $1.0 \mathrm{MPa}\left(150 \mathrm{lbf} / \mathrm{in}^{2}\right.$ gauge), and a maximum water temperature of $93^{\circ} \mathrm{C}\left(200^{\circ} \mathrm{F}\right)$.

e. The modules shall be self-shielded. The IXC vessels in the module shall be encased in a concrete structure (current $\mathrm{K}$ Basin design is $2.2 \mathrm{~m} \mathrm{x} 1.8 \mathrm{~m} \times 2.0 \mathrm{~m} \mathrm{[86 \times 70 \times}$ $79.5 \mathrm{in}$.$] high) that is placed around the vessels to provide radiation shielding.$

f. The CVDF IXM shall be operated to within the following parameters:

- $\quad<4$ microSiemens $/ \mathrm{cm}(\mu \mathrm{S} / \mathrm{cm})$ outlet conductivity

- $>70 \%$ cesium removal efficiency

- $<100$ nanoCi/g of waste collected

- $<200 \mathrm{~g}$ of plutonium collected

- $\quad<100 \mathrm{Ci}$ of ${ }^{137} \mathrm{Cs}$

- $\quad<65 \mathrm{Ci}^{90} \mathrm{Sr}$.

g. The calculated operational limit for the mass of plutonium in a IXM shall be $200 \mathrm{~g}$ each. The loading shall never exceed this amount to ensure that the absolute limit of $225 \mathrm{~g}$ is never exceeded. The absolute limit is stated in Section 2.2.1 of Operational Safety Requirements - $100 \mathrm{~K}$ East and $100 \mathrm{~K}$ West Fuel Storage Basins (WHC-SD-WM-OSR-006). The operational limit stated in Section D.1 of the Process Standard C-304 is $200 \mathrm{~g}$.

h. The operational limit for alpha material in a IXM shall be $<100$ nanoCi/g based upon total weight of the IXM including concrete shielding material. This is an economic limit in that contamination above this limit qualifies the module as TRU waste. Disposal of TRU waste is prohibitive. TRU waste is defined as a waste commodity containing greater than 100 nano $\mathrm{Cj} / \mathrm{g}$ of TRU isotopes. There is no permanent disposal path for TRU waste, so the final cost of disposing of the waste can't even be calculated. For this reason, every effort is made to prevent the generation of TRU waste. 
The inlet and outlet water of the CVDF IXM shall have composite sampling to estimate the quantity of the following constituents contained in the operating IXM:

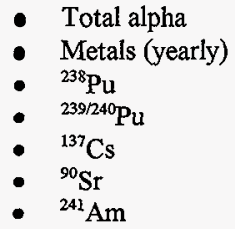

i. Water samples shall be removed from the inlet and outlet streams by the composite samplers of the CVDF water sampling and analysis system and laboratory analyzed.

j. When an IXM ${ }^{137} \mathrm{Cs}$ removal efficiency drops to $70 \%$, a replacement IXM shall be put online; and the spent IXM shall be sent to Solid Waste Handling.

k. IXMs shall be removed from service before they accumulate 80 nanoCi/g even if they used only a fraction of their ion removal capacity.

By definition, a TRU isotope has an atomic number greater than 92 (uranium), has a half-life greater than 20 years, and is an alpha emitter. The bulk water contain many TRU isotopes; however, ${ }^{241} \mathrm{Am}$ and ${ }^{239 / 240} \mathrm{Pu}$ account for greater than $95 \%$ of all alpha activity. Note: exclude ${ }^{241} \mathrm{Pu}$ because it is not an alpha emitter.

1. A spent and drained IXM shall be continually vented while being stored to protect against hydrogen buildup. Hydrogen is generated by the effect of radiation (radiolysis) on the retained water.

m. Changeout of a spent IXM require draining for 24 hours to minimize the amount of free liquids within the module. Special NUC-FL ${ }^{\mathrm{TM}}$ filters shall then be attached to the IXM vent manifold and to the module inlet. The module outlet shall be capped.

n. A portable 30-ton crane and a special spreader bar, shown on Drawing $\mathrm{H}-1-44867$, shall be used to remove the IXM out of the CVDF. The mobile crane shall be used to move the IXM out of the CVDF and onto a local storage location. From there, the IXM shall be sent to the 200 Area waste storage complex as Type B radioactive waste. The requirements for shipping and packing are found in the Safety Analysis Report for Packaging (Onsite) IXMs (WHC-SD-NR-SARP-004). 
HNF-SD-SNF-DRD-002 REV 1

5.4.4.3 Bulk Water Storage Tank.

a. There shall be a large storage tank for holding the purified water until there is enough to transfer to a tanker truck for shipment.

5.4.4.4 Conditioned Water Transfer to Tanker Truck. TBD.

5.4.4.5 Tanker Transfer to $\mathrm{K}$ West Basin. TBD.

\subsubsection{Safety Performance Requirements}

PWC system shall meet the following safety-significant design requirements.

a. Primary confinement boundary shall be designed to be leaktight against release of airborne and liquid effluents.

b. All piping and components that come in contact with contaminated effluents from the MCO shall be designed to minimize holdup and buildup of contamination and meet ALARA design criteria in Section 3.3.2 and 7.3.

Safety-Class criticality control shall meet the following performance requirements.

a. All effluents from the process shall be collected in a geometrically safe volume that is less than 24 inches inside diameter.

b. All transfers from the $\mathrm{MCO}$ or geometrically safe volume to an uncontrolled volume shall have double contingency protection.

c. The design of the double contingencies shall be physical controls that require no active components.

5.4.5.1 Operational Support Requirements. The system shall have no safety operational support requirements.

5.4.5.2 Seismic Requirements. All equipment required to perform the safety-significant primary confinement function shall be seismically qualified to $\mathrm{PC}-2$ criteria. All equipment required to perform the safety-class criticality control function shall be seismically qualified to $\mathrm{PC}-3$ criteria to perform its safety function following a design basis seismic event. If the criticality control features can be shown to remain functional by keeping their criticality control characteristics during a seismic event or after seismic failure, then these components shall be classified PC-2. A listing of these assignments is provided in Table 5-6.

5.4.5.3 Environmental Qualification. All safety components shall be designed to function under worst-case internal and external environmental conditions. These conditions are composed 
of faulted and process upset event plant conditions identified in Section 3.5.2 and the associated internal and external environmental conditions listed in Table 5-3. The design shall mitigate those conditions that represent a potential common-mode failure of safety systems and documentation shall be provided for those mitigation features.

\subsubsection{Codes and Standards}

The codes and standards applicable to the design of SSCs are listed in Table 5-2.

Table 5-6. Process Water Conditioning System Design Requirements.

\begin{tabular}{|l|c|c|c|}
\hline \multicolumn{1}{|c|}{ Components } & $\begin{array}{c}\text { Safety } \\
\text { classification }\end{array}$ & $\begin{array}{c}\text { NPH } \\
\text { performance } \\
\text { category }\end{array}$ & $\begin{array}{c}\text { Environmental } \\
\text { qualification } \\
\text { (see Table 5-3) }\end{array}$ \\
\hline Pumps & SS & PC-2 & 1 \\
\hline Tanks & SS & PC-2 & 1 \\
\hline Filters & SS & PC-2 & 1 \\
\hline $\begin{array}{l}\text { SC geometrically controlled tanks } \\
\text { and double contingency controls }\end{array}$ & SC & PC-3 & 1 \\
\hline Piping and valves & SS & PC-2 & 1 \\
\hline Sampling Equipment & SS & PC-2 & 1 \\
\hline IXM & SS & PC-2 & 1 \\
\hline Instrumentation and control & GS & PC-2 & 1 \\
\hline Support structure & SS & PC-2 & 1 \\
\hline
\end{tabular}
functions.

'This equipment is PC-3 if its failure can prevent the proper operation of safety-class criticality control

${ }^{2}$ Safety-class criticality control components may be PC-2 is shown to remain functional during and after a event.

$\mathrm{GS}=$ general services.

LXM $=$ ion exchange module.

$\mathrm{NPH}=$ natural phenomena hazard .

PC-2 = Performance Category 2.

PC-3 = Performanice Category 3.

$\mathrm{SC}=$ safety class.

$\mathrm{SS}=$ safety significant. 


\subsection{SAFETY-CLASS HELIUM SYSTEM}

\subsubsection{Location, Boundaries and Interfaces}

This system shall provide a safety-class source of helium purge gas to the $\mathrm{MCO}$. This helium gas is used to remove accumulated hydrogen from the $\mathrm{MCO}$ and provide thermal conduction of the heat generated by the fuel corrosion reaction.

5.5.1.1 Location. There shall be four separate SCHe systems, one for each process located in each bay. All necessary equipment required to perform the SCHe system safety-class functions shall be located in the process bay.

\subsubsection{Boundaries and interfaces.}

a. Each system shall receive actuation signals from and/or input to the SCI\&C system.

b. Each helium supply train and vent train shall receive signals from two SCI\&C output trains of controls, train A and train B (see IEEE Standard 603-1991 requirements [IEEE 1991]).

c. Each system shall use non-safety control power supplied by the facility UPS. Proper isolation from the effects of power transients and failures shall be provided such that the safety functions can still be accomplished under power loss or transient conditions.

d. Each system shall interface with the facility MCS for non-safety instrumentation and control functions operation from the control room. The MCS normal control operation shall not degrade or prevent the safety function operation.

\subsubsection{Process Functional Requirements}

SCHe is a standby safety system only and has no process functions or requirements.

\subsubsection{Safety Functional Requirements}

The SCHe system shall provide a safety-class source of helium purge gas to the MCO. This helium gas is used to remove accumulated hydrogen from the MCO and provide thermal conduction of the heat generated by the fuel corrosion reaction.

The following are the safety function requirements for SCHe summarized from Section 3.0 , Table 3-7. See Section 3 for further descriptions of these safety functions.

- Prevention of runaway corrosion reaction 
- Prevention of hydrogen deflagration/detonation in the $\mathrm{MCO}$

- NPH Mitigation (Seismic)

$\mathrm{SCHe}$ is a safety-class system that is required to be functional before and after a seismic event (PC-3).

\subsubsection{Process Performance Requirements}

None.

\subsubsection{Safety Performance Requirements}

a. The equipment shall be part of the SCI\&C system operation and shall be operable during all times the VPS is connected to the MCO and the MCO port valves are open.

b. The SCHe system shall use a pressurized source of helium, piping, control valves, and instrumentation and controls to deliver helium to the $\mathrm{MCO}$ and shall provide a vent path for purging MCO gases. All components required to perform the injection and venting functions are designated safety class.

c. Each system shall provide two redundant trains of helium supply, one for each MCO connection port.

d. Each system shall provide a redundant means to vent purged gases from the MCO through the HEPA-filtered MCO port connection.

e. The SCHe system shall use fail-open electrically operated isolation valves.

f. Isolation valves shall be capable of providing reliable, leaktight (specification on leak rate required) operation, including fail-safe operation upon loss of control signal or instrument air.

g. Isolation valves shall, upon receipt of an actuation signal from the SCI\&C system, go open and lock out all other non-safety control signals and functions until reset by the SCI\&C system or through manual override by the operator. Non-safety operation control signals from the MCS must not affect or degrade the safety-class operation.

h. The capacity for the helium bottles to provide MCO purge and pressure control shall be based on the worst-case safety-class line break inside the isolation valves. This single failure will not occur during a seismic event, and therefore operator response shall be available within 1 hour from the time of safety-class initiation alarm notification. This analysis shall be documented. 
i. An evaluation of the potential for plugging the SCHe injection ports shall be conducted.

j. A single point failure analysis shall be performed and documented in accordance with IEEE-603.

k. SCHe bottle pressure shall be provided, both locally (non-powered) and remotely (powered).

1. Safety-class indication of both supply and purge return flow shall be provided, both locally (non-powered) and remotely (powered, for safety-class logic).

m. A safety-class low bottle pressure alarm shall be transmitted to the CVDF control room.

n. An SCHe initiation alarm shall be provided to the CVDF control room. This alarm shall be based on the SCI\&C control logic.

5.5.5.1 Operational Support Requirements. The following operational support requirements shall be met.

a. The system shall be designed to not require safety-class electric power, instrument air, or any other support function.

b. Fail-safe criteria shall be applied throughout the design of all safety-class systems. Fail-safe is defined as failing to the safety function operation position. A loss of power or control air shall result in a safe shutdown for example.

c. Electrical isolation shall be provided to separate the class $1 \mathrm{E}$ system from this non-safety system. This would include all interfacing with the MCS and the non-IE power source.

d. Isolation from the potential effects of degradation or failure of instrument air shall be provided.

5.5.5.2 Seismic Requirements. All equipment required to perform the helium injection and venting function shall be seismically qualified to $\mathrm{PC}-3$ criteria (see Section 3.1 .4 ) to perform its safety function following a design basis seismic event. A listing of the seismic assignments is in Table 5-7.

5.5.5.3 Environmental Qualification. All safety-class components shall be designed to function under worst-case internal and external environmental conditions. These conditions are composed of faulted and process upset event plant conditions identified in Section 3.5.2 and the associated internal and external environmental conditions listed in Table 5-3. The design shall mitigate those 
conditions that represent a potential common-mode failure of safety systems and documentation shall be provided for those mitigation features.

\subsubsection{Codes and Standards}

The codes and standards applicable to the design of SSCs are listed in Table 5-2.

Table 5-7, Safety Class Helium System Design Requirements.

\begin{tabular}{|l|c|c|c|}
\hline \multicolumn{1}{|c|}{ Components } & $\begin{array}{c}\text { Safety } \\
\text { classification }\end{array}$ & $\begin{array}{c}\text { NPH } \\
\text { performance } \\
\text { category }\end{array}$ & $\begin{array}{c}\text { Environmental } \\
\text { qualification } \\
\text { (see Table 5-3) }\end{array}$ \\
\hline $\begin{array}{l}\text { All tanks, lines, valves and other } \\
\text { components }\end{array}$ & SC & PC-3 & 1 through 9 \\
\hline Instrumentation and control & SC & PC-3 & 1 through 9 \\
\hline Support structure & SC & PC-3 & 1 through 9 \\
\hline
\end{tabular}

${ }^{1}$ This equipment is PC-3 only if it is required to remain functional after a seismic event.

$\mathrm{NPH}=$ natural phenomena hazard.

PC-3 = Performance Category 3 .

$\mathrm{SC}=$ safety class.

\subsection{SAFETY-CLASS INSTRUMENTATION AND CONTROL SYSTEM}

\subsubsection{Location, Boundaries and Interfaces}

The SCI\&C system shall provide safety-class sensing, actuation logic, actuation signals, and control interfaces to prevent $\mathrm{MCO}$ fuel runaway reaction (over temperature) and $\mathrm{MCO}$ hydrogen deflagration/detonation. The SCI\&C system includes all of the instruments, actuation logic, electrical cabinets, conduits and wiring, local and remote indications and controls to operate the system.

5.6.1.1 Location. There shall be four separate SCI\&C systems, one for each process, located in each bay. All necessary equipment required to perform the systems' minimum safety-class functions shall be located within the process bay. 


\subsubsection{Boundaries and Interfaces.}

a. Each system shall receive input from and/or provide actuation signals to the SCHe system components, VPS isolation components and the cask annulus water protection components.

b. Each system shall use non-safety control power supplied by the facility UPS. Proper isolation from the effects of power transients and failures shall be provided such that the safety functions can still be accomplished under power loss or transient conditions.

c. Each system shall interface with the facility MCS for non-safety instrumentation and control functions operation from the control room. The MCS normal control operation shall not degrade or prevent the safety function operation.

\subsubsection{Process Functional Requirements}

SCI\&C is a standby safety system only and has no process functions or requirements.

\subsubsection{Safety Functional Requirements}

The SCI\&C system provides safety-class sensing, actuation logic, actuation signals, and control interfaces to prevent $\mathrm{MCO}$ fuel runaway reaction (over temperature) and MCO hydrogen deflagration/detonation. The SCI\&C system includes all of the instruments, actuation logic, electrical cabinets, conduits and wiring, local and remote indications, and controls to operate the system.

The following are the safety function requirements for VPS summarized from Section 3.0, Table 3-7. See Section 3 for further descriptions of these safety functions.

- Prevention of runaway corrosion reaction

- Prevention of hydrogen deflagration/detonation in the MCO

- NPH Mitigation (Seismic)

$\mathrm{SCI} \& \mathrm{C}$ is a safety-class system that is required to be functional before and after a seismic event (PC-3).

\subsubsection{Process Performance Requirements}

None. 


\subsubsection{Safety Performance Requirements}

The SCI\&C system and the SCHe system are to be automatic systems that operate independent of the operator once they are enabled for processing. The enabling and disabling of the systems at the beginning and the end of a process cycle will be under administrative control. This assumes the operators can "walk away," and the systems will place and maintain the MCO in a safe shutdown condition until the recovery procedure is completed. The system minimum safe shutdown operating times before operator recovery will be determined for each type of initiating event. The goal for "hands off" operation to maintain the MCO in a safe configuration is 96 hours.

Initiation of the safe shutdown can either be automatic with the SCI\&C system or manual with operator initiation. Manual operator initiation buttons will be located in the control room, outside each bay transfer corridor access door, and in each bay. Manual interaction by the operator during, or during recovery from, an SCHe purge safe shutdown actuation will be under technical specification control and proceduralized to ensure proper operator actions. Operators must be trained to the procedures for operation of the systems.

The control room MCS shall have the capability to open or close any of the safety-class valves as long as the safety logic is not requiring an isolation and helium purge. A similar "safe shutdown" lineup shall be determined using both normal and SCHe supply.

The system shall provide the following actuations and trips:

- Manual actuation

- Loss of power or control trip actuation

- Seismic trip actuation

- Water over temperature heater trip or isolation

- Gas over temperature heater trip or isolation

- MCO low pressure < atm and/or insufficient helium purge time trip

- Loss of helium purge trip

- Vacuum cycle over time limit trip

- Helium cycle under time limit trip.

Each system shall have two redundant trains of controls, train A and train B. The control circuits can be housed in a single cabinet provided separation and isolation is adequate for each train (see IEEE Standard 603-1991 requirements [IEEE 1991]).

The system shall have one safety-class annunciator panel located in the control room to display and monitor system alarm status for each bay (see Figure 5-1).

Each system shall have a local control panel located within each bay for alarm status and control of each system (see Figure 5-2). 
Figure 5-1. Example of Cold Vacuum Drying Facility Safety Class Logic Panel Train A.

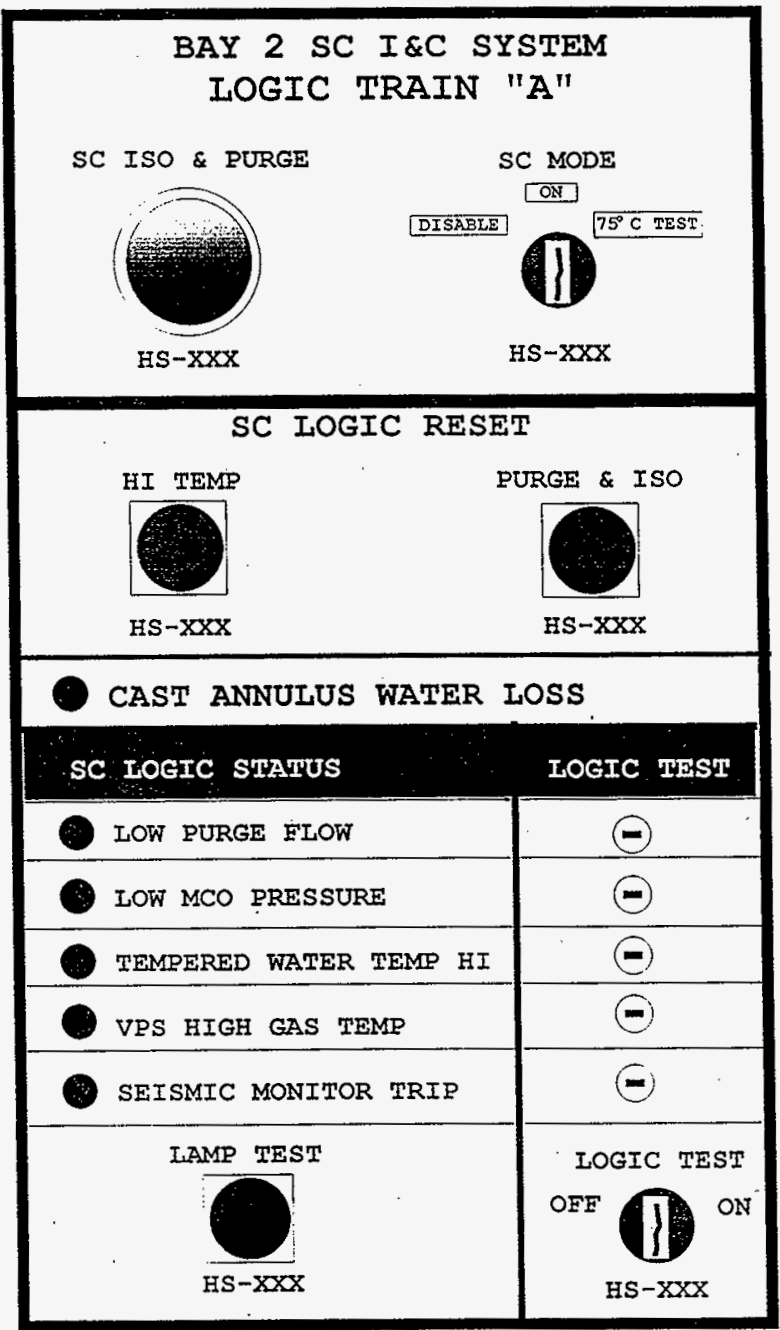


Figure 5-2. Example of Safety Class Relay Logic Schematic.

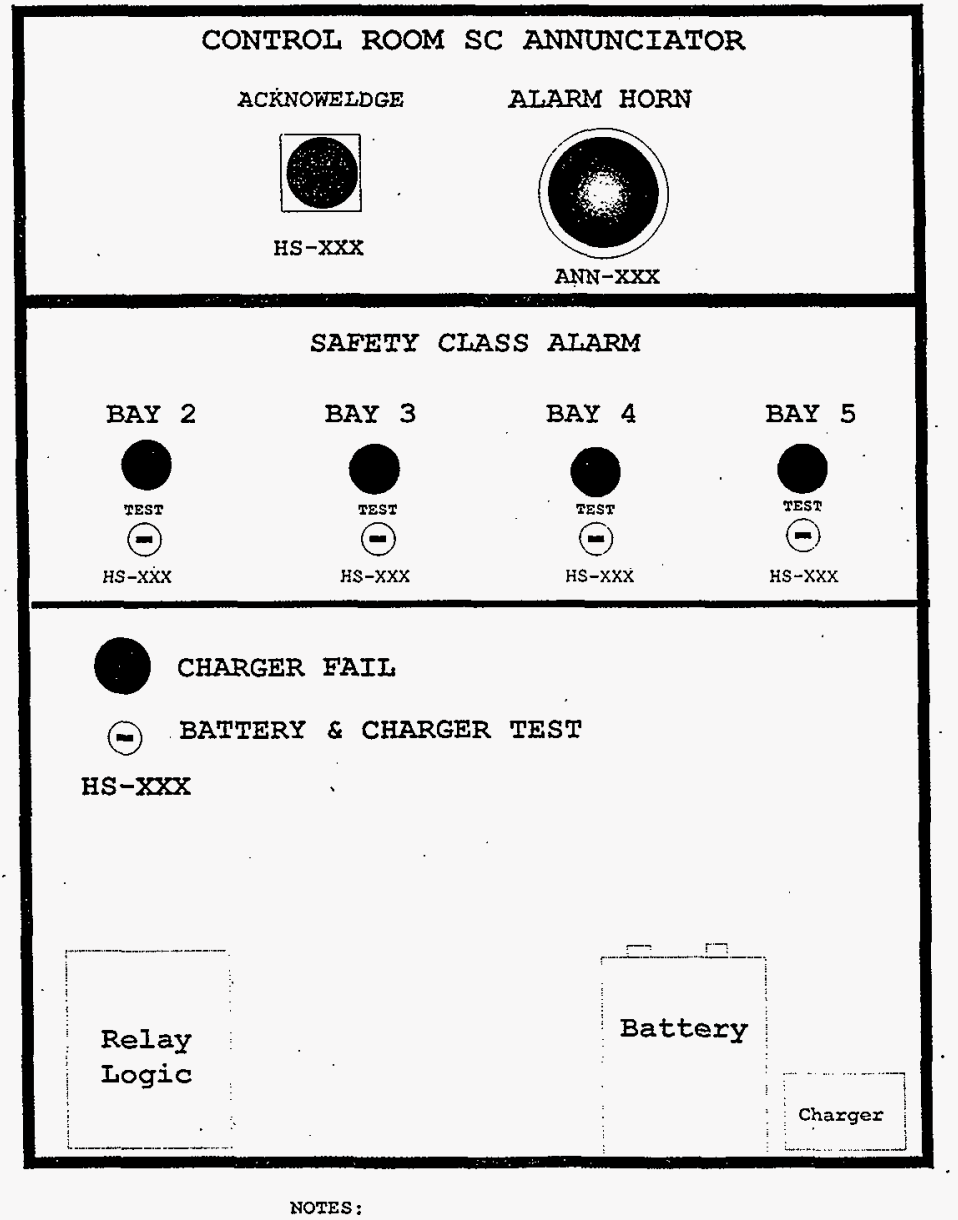

Panel must be qualified and mounted to building structual requirments.

All alarms are Fail safe on loss of signal from sc Logic in bays and loss of battery power. Signals come from both "A" and "B" logic trains

Chargex power can be ups or normal power. 
A single point failure analysis shall be performed and documented in accordance with IEEE-603.

\subsubsection{Combined $50^{\circ} \mathrm{C}$ and $75^{\circ} \mathrm{C}$ Mode Requirements.}

a. Water shall be maintained in the MCO cask annulus above the level of the highest fuel under all DBA conditions. For a DBA seismic event, operator action shall not be required within 96 hours. A safety-class alarm to the CVDF control room shall be initiated if water level goes below the upper scrap basket for non-seismic events.

b. Seismic recorders shall be used to detect, record, and trip on a seismic event exceeding a level in excess of normal Uniform Building Code (UBC) values, which guarantees no damage to non-seismic components and structures (suggest a setting of $0.05 \mathrm{~g}$, triaxial). This seismic trip shall be class $1 \mathrm{E}$ with class $1 \mathrm{E}$, self-contained backup power to operate before and during an earthquake.

c. No single failure condition shall result in the MCO pressure dropping below atmosphere using either the normal or SCHe pressure control.

d. When first opening or when closing the MCO plug valves, VPS-V-*10 must be opened first and closed last to establish and maintain pressure control. The MODE switch shall be selected to "ON" before VPS-V-*10 is opened and will not be selected to "OFF" until all plug valves are closed. These controls shall be administrative.

e. As an administrative measure to ensure a gas flow path through the MCO's HEPA filter and to ensure the safety-class instrumentation is functioning, a bubble purge shall be initiated through the long process tube and out the HEPA filter. This purge also will reduce the concentration of hydrogen immediately after hookup. A pressure drop evaluation shall be completed to show adequate supply pressure.

\subsubsection{2 $50^{\circ} \mathrm{C}$ Mode Requirements.}

a. One of the following control strategies shall be employed to prevent hydrogen deflagration/detonation whenever any of the MCO plug valves is opened. Failure to meet one of these requirements shall initiate an SCHe purge.

- The MCO shall be maintained above atmospheric pressure to prevent air ingress (prevents deflagration/detonation).

- The MCO hydrogen (from fuel reactions) and oxygen (via air inleakage) content shall be controlled to below the lower flammability limit.

b. For condition 1 above, MCO safety-class pressure monitoring shall be provided. The sensor location shall monitor MCO gas space, which would require a location downstream of the MCO HEPA filter. This pressure sensor shall be located inside the 
MCO safety-class isolation valve. The detection capability shall be sufficient to detect a drop in pressure and respond to maintain pressure above atmosphere under the worst-case line break. In addition, inadvertent means that would prevent pressure control (i.e., vacuum pump or ejector operation) shall be prevented.

c. For condition 2 above, the method used to control the $\mathrm{H}_{2}$ content shall be a helium purge to remove hydrogen as it is being produced (continuous purge) or to sweep accumulated $\mathrm{H}_{2}$ (feed and bleed) if the purge is stopped or interrupted.

The control of $\mathrm{O}_{2}$ concentration via inleakage cannot be guaranteed under vacuum, and therefore, may not be used. Before intentionally entering vacuum mode, a continuous purge shall be completed. Failure to perform the required purge shall initiate an SCHe purge.

d. A helium purge rate sufficient to remove accumulated or generated hydrogen and any potential oxygen from inleakage shall be determined and documented. For design purposes, assume a minimum flow rate of $1.2 \times 10^{-3} \mathrm{~m}^{3} / \mathrm{sec}\left(2.5 \mathrm{ft}^{3} / \mathrm{min}\right)$. This minimum flow rate and minimum purge time shall establish the following conditions:

- Low $\mathrm{H}_{2}$ concentrations when below atmospheric pressure thus allowing for an unlimited amount of air inleakage without challenging the lower flammability limit. Note that the time to accumulate $\mathrm{H}_{2}$ to reach the lower flammability limit allows for a time period below atmospheric pressure without the need for a purge.

- Low $\mathrm{O}_{2}$ concentrations after pressure drops below atmospheric pressure and before $\mathrm{H}_{2}$ buildup can reach the lower flammability limit.

e. Heat input to the MCO from the tempered water heater shall be limited. A safety-class temperature control scheme shall be employed to monitor and prevent temperature inputs to the MCO from exceeding either the lower or upper temperature setpoint. The lower temperature setpoint range shall be between $20^{\circ} \mathrm{C}$ and $75^{\circ} \mathrm{C}$ $\left(68^{\circ} \mathrm{F}\right.$ and $167^{\circ} \mathrm{F}$ ) and the upper shall be between $35^{\circ} \mathrm{C}$ and $95^{\circ} \mathrm{C}\left(95^{\circ} \mathrm{F}\right.$ and $203^{\circ} \mathrm{F}$ ). A means to prevent heat from reaching the MCO (i.e., heater shutoff or stopping flow) shall be initiated if the temperature setpoint is exceeded. Any actuation shall require a manually operated "reset."

f. The maximum time below atmospheric pressure is 8 hours should pressure drop below atmospheric pressure for more than 1 minute, a minimum 4-hour purge is required. All subsequent vacuum cycles shall be limited to less than 4 hours with a 4-hour cooldown (positive pressure) cycle complete before going below atmospheric pressure. This control shall be electronic and not administrative. Note that the minute allowance for going under vacuum will prevent the false requirement for a 4-hour cooldown should an unexpected short-term pressure loss occur. 


\subsubsection{3 $75^{\circ} \mathrm{C}$ Mode Requirements.}

a. The following control strategies shall be employed to prevent hydrogen deflagration/detonation whenever any of the $\mathrm{MCO}$ plug valves is opened and before entering the $75^{\circ} \mathrm{C}$ mode $\left(167^{\circ} \mathrm{F}\right)$. Failure to meet any of these requirements shall automatically initiate an $\mathrm{SCHe}$ purge.

- The MCO shall be maintained above atmospheric pressure to prevent air ingress (prevents detonation/deflagration).

- Before entering the $75^{\circ} \mathrm{C}\left(167^{\circ} \mathrm{F}\right)$ mode, $\mathrm{O}_{2}$ concentration shall be less than $0.1 \%$ of the gas volume.

- Valves GOV 1*30, MOV 1211, MOV 1311, MOV 1411, and MOV 1511 shall be closed and electrically interlocked to prevent opening. Note that improper valve lineup could result in water addition to the $\mathrm{MCO}$ that is unacceptable during the $75^{\circ} \mathrm{C}\left(167^{\circ} \mathrm{F}\right)$ mode.

b. The entry into the testing phase shall be under administrative control.

\subsubsection{Recovery from Automatic Initiations.}

a. Recovery from an SCHe purge and isolation shall be manually initiated in the respective bay. Control logic shall reset automatically; however, the final output logic will require a local manual reset.

b. Recovery from a seismic trip shall require manual reset at the location of the seismic recorders, train A and B. Auctioneering of three units (2/3 logic) may be utilized.

c. Recovery from high heat input trips shall be in the respective bays. Control logic shall reset automatically; however, the final output logic will require manual local reset.

\subsubsection{Instrumentation and Control}

The control room controls must allow for complete remote indication and operation of the system to allow for recovery from an initiation in the event the bay is not accessible.

The following functions shall be provided in each bay for logic train $\mathrm{A}$ and logic train $\mathrm{B}$.

a. Safety-class, operator-controlled "MODE" switches to disable ("OFF" position) and enable ("ON" position) the safety-class logic $A$ and $B$ trains shall be provided. In addition, a position $\left(75^{\circ} \mathrm{C}\right.$ TEST) for overriding the $50^{\circ} \mathrm{C}\left(122^{\circ} \mathrm{F}\right)$ high temperature trip shall be provided. These switches shall have bay-specific key locks (i.e., one key for both logic trains but different for each bay). 
b. Safe shutdown actuation switches shall be provided at the SCI\&C panel in each bay. Either train A or B push button shall initiate the safety-class purge and MCO isolation. A method shall be employed to prevent inadvertent actuation and to provide non-1E illuminated status when the purge has been activated by this switch.

c. SCHe MCO pressure indication, as measured inside the MCO safety-class isolation valve, shall be provided both locally (non-powered) and remotely (powered).

d. Safety-class logic trip status indication, with lamp test button, shall be provided. As an example, the following types of signals would be displayed:

- Seismic monitor trip

- $\quad$ Tempered water HI TEMP

- Low cask water level

- Low purge flow

- Low MCO pressure.

e. A safety-class "logic test" keylocked switch shall be provided at each bay to allow for testing. In addition, individual toggle switches for testing each logic train signal shall be provided. The status light shall verify the actuation of the logic signal via this test.

f. Signals shall be provided from all powered safety-class instruments to the non-safety MCS. This includes safety logic signals, alarms, and timer counters used for SCHe purge initiation. Class $1 \mathrm{E}$ isolation shall be provided, as required.

g. Key locks for an individual bay for the mode switches (train A and train B) and the safety logic trip test shall be keyed the same. This will require only one key per bay and a total of four unique keys.

h. Status lights shall be provided for all safety-class logic trips. These lights will remain illuminated even after the trip condition has cleared until manually reset by the operator in the respective bay.

i. A reset button shall be provided to reset the high heat input (HI TEMP) tempered water trip. The actual logic shall clear automatically when the condition is below the reset value; however, the trip status shall remain until this reset button is pushed.

j. A class $1 \mathrm{E}$ means to override the $50^{\circ} \mathrm{C}\left(122^{\circ} \mathrm{F}\right)$ heat input for the tempered water heaters shall be provided via the mode selector switch position " $75^{\circ} \mathrm{C}$ TEST."

k. Both local (non-powered) and remote (powered, used for safety-class logic) class $1 \mathrm{E}$ MCO pressure indication shall be provided on the short process tube inside the safety-class boundary. 
1. Local (non-powered) safety class indication shall be provided for the MCO cask annulus water level. This indication shall be readable by an operator for the water full, normal, and empty conditions. Furthermore, the resolution must be such that the difference between the top of the inner fuel basket and the normally full condition can be resolved.

m. For any timers used an automatic means to reset timer shall be provided.

5.6.6.1 Operational Support Requirements. The following operational support requirements shail be met.

a. The control logic and instruments shall be powered from the non-safety UPS. Analysis or testing must be performed to ensure this non-safety power cannot affect the safety-class features being performed. See DOE Order 6430.1A for specific guidance.

b. A loss of MCS (non-safety) shall not automatically initiate the SCHe purge; however, the MCS can operate all safety-class valves as long as there is no safety-class logic trip.

c. The system shall be designed to not require safety-class electric power, instrument air, or any other support function.

d. Fail-safe criteria shall be applied throughout the design of all safety-class systems. A loss of power or control air shall result in a safe shutdown for example.

e. Electrical isolation shall be provided to separate the class $1 \mathrm{E}$ system from this non-safety system. This would include all interfacing with the MCS and the non-1E power source.

5.6.6.2 Seismic Requirements. All equipment required to perform the SCI\&C safety functions shall be seismically qualified to PC-3 criteria (see Section 3.1.4) to perform its safety function following a design basis seismic event.

a. Seismically qualified final relays in the safety-class logic shall be used to prevent "seismically induced chatter." With this control scheme in mind, isolated signals from the MCS shall be able to control the open and close position of any of the SCHe and $\mathrm{MCO}$ isolation valves, provided the SCHe has not been initiated. A possible scheme for this is to have the safety-class logic feed these relays in series with the MCS isolated contact. In no case shall the MCS or any other non-safety system prevent the activation of the SCHe system and isolation.

b. In the case of CVDF control room annunciator, there is no requirement to meet PC-3 seismic design criteria. The use of seismic monitors eliminates the need to seismically 
qualify the safety-class instruments and electronics as long as a seismically qualified seal-in function is provided.

5.6.6.3 Environmental Qualification. All safety-class components shall be designed to function under worst-case internal and external environmental conditions. These conditions are composed of faulted and process upset event plant conditions identified in Section 3.5 .2 and the associated internal and external environmental conditions listed in Table 5-3. The design shall mitigate those conditions that represent a potential common-mode failure of safety systems and documentation shall be provided for those mitigation features.

Table 5-8. Safety Class Instrumentation and Control System Design Requirements.

\begin{tabular}{|l|c|c|c|}
\hline \multicolumn{1}{|c|}{ Components } & $\begin{array}{c}\text { Safety } \\
\text { classification }\end{array}$ & $\begin{array}{c}\text { NPH } \\
\text { performance } \\
\text { category }\end{array}$ & $\begin{array}{c}\text { Environmental } \\
\text { qualification } \\
\text { (see Table 5-3) }\end{array}$ \\
\hline All components & SC & PC-3 & 1 through 9 \\
\hline Support structure & SC & PC-3 & 1 through 9 \\
\hline
\end{tabular}

${ }^{1}$ Equipment is PC-3 only if it is required to remain functional after a seismic event.

PC-3 = Performance Category 3 .

$\mathrm{SC}=$ safety class.

\subsubsection{Codes and Standards}

The codes and standards applicable to the design of SSCs are listed in Table 5-2.

\subsection{REFERENCES}

ACGIH Requirements, American Conference of Governmental Industrial Hygienists, Cincinnati, Ohio.

ACI-318, 1996, Building Code Requirements for Reinforced Concrete, American Concrete Institute, Farmington Hills, Michigan.

ACI-349, 1996, Code Requirements for Nuclear Safety Related Concrete Structures, American Concrete Institute, Detroit, Michigan.

AFBMA, Anti-Friction Bearing Manufacturers Association, Incorporated, Washington, D.D. AICHE, American Institute of Chemical Engineers, New York, New York. 
AISC-M011, 1996, Manual of Steel Construction, American Iron and Steel Institute, Washington, D.C.

ANSJ/AISC- N690, 1996, Nuclear Facilities: Steel Safety-Related Structures for Design, Fabrication and Erection, American Iron and Steel Institute, Washington, D.C.

ANSU/ASME B31.1, 1996, Power Piping Code, American Society of Mechanical Engineers, New York, New York.

ANSI/ASME B31.3, 1996, Chemical Plant and Petroleum Refinery Piping Code, American Society of Mechanical Engineers, New York, New York.

ANSI/ASME B31.5, 1996, Refrigerant Piping Code, American Society of Mechanical Engineers, New York, New York.

ANSI/ASME B31.9, 1996, General Services Piping Code, American Society of Mechanical Engineers, New York, New York.

ANSUASME B-16 series, 1996, Fittings, Flanges and Valves, American Society of Mechanical Engineers, New York, New York.

ANSI/ASME 373.1M, 2M, American Society of Mechanical Engineers, New York, New York.

ANST/ASME N509, 1996, Nuclear Power Plant Air Cleaning Units and Components, American Society of Mechanical Engineers, New York, New York.

ANSU/ASME N510, 1996, Testing of Nuclear Air Cleaning System, American Society of Mechanical Engineers, New York, New York.

ANSI/ISA-S5.1-1984 (R1992), 1984, Instrumentation Symbols and Identification, Instrument Society of America, Research Triangle Park, North Carolina.

ANSI/ISA-S18.1-1979 (R1985), 1979, Annunciator Sequences and Specifications, Instrument Society of America, Research Triangle Park, North Carolina.

ANSI-N278, American National Standards Institute, New York, New York.

ASHRAE-52.68, American Society of Heating, Refrigerating and Air-Conditioning Engineers, Atlanta, Georgia $\not$

ASME Code, 1995, Boiler and Pressure Vessel Code, American Society of Mechanical Engineers, New York, New York.

AWS-D1.1, 1996, Structural Welding Code-Steel, American Welding Society, Miami, Florida. 
AWWA-D100-96, 1996, Welded Steel Tanks for Water Storage, American Water Works Association, Denver, Colorado.

DOE Order 5480.28, 1993, Natural Phenomena Hazards Mitigation, U.S. Department of Energy, Washington, D.C.

DOE Order 6430.1A, 1989, General Design Criteria, U.S. Department of Energy, Washington, D.C.

DOE-STD-1021-93, 1993, Natural Phenomena Hazards Performance Categorization Guidelines for Structures, Systems, and Components, U.S. Department of Energy, Washington, D.C.

DOE-STD-XXXX, Human Engineering Design Criteria, Volume I, Draft, U.S. Department of Energy, Washington, D.C.

ERDA-7621, Energy Research and Development Administration, Washington, D.C.

IEEE-577, Standard Requirements for Reliability Analysis in the Design and Operation of Safety Systems for Nuclear Power Generating Stations, Institute of Electrical and Electronic Engineering, Piscataway, New Jersey.

IEEE-603-1991, 1991, Standard Criteria for Safety Systems for Nuclear Power Generating Stations, Institute of Electrical and Electronic Engineering, Piscataway, New Jersey.

ISA-S5.4-1989, 1989, Instrument Loop Diagrams, Instrument Society of America, Research Triangle Park, North Carolina.

ISA-S20-1981, 1981, Specification Forms for Process Measurement and Control Instruments Primary Elements and Control Valves, Instrument Society of America, Research Triangle Park, North Carolina.

MLL-F-51068C, U.S. Department of Defense, Washington, D.C.

MU-STD-1472E, Human Engineering Design Criteria for Military Systems, Equipment, and Facilities, U.S. Department of Defense, Washington, D.C.

NFPA 70, 1996, National Electrical Code, National Fire Protection Association, Quincy, Massachusetts.

NUREG-0700, Guidelines for Control Room Design Reviews, U.S. Nuclear Regulatory Commission, Washington, D.C.

NUREG-0800, 1981, Standard Review Plan, Section 18.1, U.S. Nuclear Regulatory Commission, Publications Division, Washington, DC 20555 


\section{HNF-SD-SNF-DRD-002 REV 1}

OSHA, Occupational Safety and Health Administration, Washington, D.C.

Process Standard C-304, [K-Basin IXM], Rev. 0, Westinghouse Hanford Company, Richland, Washington.

SMACNA, HVAC Duct Construction Standards--Metal and Flexible, Sheet Metal and Air Conditioning Contractors National Association, Vienna, Virginia.

SMACNA, HVAC Duct Design Manual, Sheet Metal and Air Conditioning Contractors National Association, Vienna, Virginia.

Specification W-441-P3, Rev. 0, Westinghouse Hanford Company, Richland, Washington.

TEMA, Tubular Exchanger Manufacturers Association, Tarrytown, New York.

UBC, 1994, Uniform Building Code, International Conference of Building Officials, Whittier, California.

UL-58, Underwriters Laboratories, Northbrook, Illinois.

UL-142, Underwriters Laboratories, Northbrook, Illinois.

WHC-S-0142, Procurement Specification for Ion Exchange Modules, Rev. 0, Westinghouse Hanford Company, Richland, Washington.

WHC-SD-GN-DGS-30006, 1993, Seismic Design Guide for Safety Class 3 and 4 Equipment at the Hanford Site, Rev. 1, Westinghouse Hanford Company, Richland, Washington.

WHC-SD-NR-ȘARP-004, Safety Analysis Report for Packaging (Onsite) Ion Exchange Modules, Rev. 0, Westinghouse Hanford Company, Richland, Washington.

WHC-SD-SNF-DB-010, 1996, Cold Vacuum Drying System Natural Phenomena Hazards, Rev. 1, Westinghouse Hanford Company, Richland, Washington.

WHC-SD-TD-SARP-016, Safety Analysis Report Packaging for the Hanford ECOROK Packaging, Rev. 0, Westinghouse Hanford Company, Richland, Washington.

WHC-SD-WM-OSR-006, Operational Safety Requirements - $100 \mathrm{~K}$ East and $100 \mathrm{~K}$ West Fuel Storage Basins, Rev. 0, Westinghouse Hanford Company, Richland, Washington.

Drawings

H-2-825868, SNF Project Level o Process Flow Diagram, DESH, Richland, Washington. 
H-1-81166, SNF Project K-Basin Vacuum Drying Level 1 Process Flow Diagram, DESH, Richland, Washington.

H-1-82166, Cold Vacuum Drying Facility Process Equipment Skid Flow Diagram, DESH, Richland, Washington.

H-1-44867, Target Assembly Packaging Equipment Lift Eye Assembly, UNC Nuclear Industries, Richland, Washington. 
HNF-SD-SNF-DRD-002 REV 1

This page intentionally left blank. 


\subsection{FACILITY DESIGN REQUIREMENTS}

\subsection{GENERAL REQUIREMENTS}

DOE Order 6430.1A, General Design Criteria, provides overall general design requirements applicable to all structures, systems and components. The applicable sections of DOE Order 6430.1A for CVDF are listed in Appendix A. The applicability of these sections are based on CVDF being designated as a nuclear facility under "special facilities" which includes consideration of design requirements under Section 1304, "Plutonium Processing and Handling Facilities," and Section 1324, :Irradiated Fissile Material Storage Facilities."

The following general requirements subsections list the general requirements applicable to all of the SSCs in Chapter 6.0. These general requirements are applicable in addition to the system specific requirements found in Chapter 6.0 .

\subsubsection{Facility Functional Requirements}

The general facility requirements from Chapter 2.0 are summarized and listed in Table 6-1. Table 6-1 assigns these facility functional requirements to the appropriate facility structures, systems and components in this section.

6.1.1.1 Equipment Classification, Codes and Standards. All SSCs in the CVDF shall be tabulated in a facility equipment list. Appendix $\mathrm{E}$ provides a sample equipment list format. This table shall list SSC classification category, NPH PC, design codes and standards, quality assurance requirements and supporting design information.

Table 6-2 defines the codes and standards to be utilized for the design of the CVDF process SSCs. Each SSC shall be assigned one of the following classification categories: general services, safety significant, or safety class. General services is the non-safety classification category and safety significant and safety class are the two safety classification categories. All CVDF SSCs shall be assigned the general services category unless assigned to one of the two safety classification categories.

6.1.1.2 Reliability, Availability and Maintainability. All facility structures and systems shall be allocated reliability, availability and maintainability goals associated with meeting the overall facility processing mission goal defined in Section 2.2.1. All facility equipment and components shall have a reliability, availability and maintainability goal associated with meeting the overall system goal. Reliability, availability and maintainability goals for SSCs shall be chosen based on the facility maintenance requirements also defined in Section 6.1.3. 
Table 6-1. Facility and Safety Functional Requirements.

\begin{tabular}{|c|c|c|c|c|c|c|}
\hline \multirow[b]{2}{*}{ Section } & \multirow[b]{2}{*}{ Functional requirements } & \multicolumn{5}{|c|}{ Facility structures and systems } \\
\hline & & Overall facility & Process bays & $\begin{array}{l}\text { Administration } \\
\text { area }\end{array}$ & $\begin{array}{l}\text { Process water } \\
\text { tank room }\end{array}$ & $\begin{array}{l}\text { Transfer corridor } \\
\text { and mechanical } \\
\text { room }\end{array}$ \\
\hline \multicolumn{7}{|c|}{ Facility functional requirements } \\
\hline 2.2 .1 & Facility mission & $x$ & $x$ & $x$ & & \\
\hline 2.2 .1 .2 & Heo-onnections & $\mathrm{F}$ & & & & \\
\hline 2.2 .2 .2 & Eak and transportor comnections & & * & & & \\
\hline \multirow[t]{2}{*}{$2: 2,2.3$} & 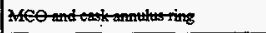 & . & \# & & & \\
\hline & & & $x$ & & & \\
\hline 2.2 .2 .5 & fempered water cireuth ton syotern & & $\approx$ & & & \\
\hline $2-2=6$ & Ifelinmorupply & ※ & * & & & \\
\hline 2.2 .2 & Receipt of cask-MCO & $x$ & $x$ & & & \\
\hline 2.3 .2 .1 & Eying process & \# & & & & \\
\hline 2.3 .2 .2 & Ges rovintetion & 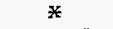 & & & & \\
\hline $292-3$ & Evaruation & * & & & & \\
\hline 2.2 .8 & Process vents and exhausts & $\mathrm{x}$ & $x$ & & $\mathrm{x}$ & \\
\hline 2.2 .9 & Facility requirements & $\mathrm{x}$ & $\mathrm{x}$ & $\mathrm{x}$ & $\mathrm{x}$ & $\mathrm{x}$ \\
\hline 2.3 .2 .6 & Frocontrols & & & & & \\
\hline 23.3 & Gusk-MEOrenefrom & & & & & \\
\hline $2-3=4$ & Exying prooeso product witoria & & & & & \\
\hline 2.2 .10 & Process conditions of operation & $\mathrm{x}$ & $\mathrm{x}$ & & $x$ & \\
\hline \multicolumn{7}{|c|}{ Safety functional requirements } \\
\hline 3.4 .1 & Confinement & $x$ & $\mathrm{x}$ & $\mathrm{x}$ & $\cdot$ & \\
\hline 3.4 .7 & Natural phenomena hazard mitigation & $x$ & $\mathrm{x}$ & & $\mathrm{x}$ & $x$ \\
\hline 3.4 .8 & Worker safety hazards protection & $x$ & $\mathrm{x}$ & $\mathrm{x}$ & $\mathrm{x}$ & $x$ \\
\hline 3.5 .1 & Facility and process safe shutdown & $\mathrm{x}$ & $\mathrm{x}$ & & $\mathrm{x}$ & $x$ \\
\hline 3.5 .2 & Design basis events & $\mathrm{x}$ & $\mathrm{x}$ & $\mathrm{x}$ & $x$ & $x$ \\
\hline 3.5 .3 & Environmental qualification & $x$ & $\mathrm{x}$ & $\mathrm{x}$ & $\mathrm{x}$ & $x$ \\
\hline
\end{tabular}

CVDF $=$ Cold Vacuum Drying Facility.

$\mathrm{MCO}=$ multicanister overpack. 
Table 6-2. Required Codes and Standards for the Cold Vacuum Drying Facility Process System Structures, Systems, and Components.

\begin{tabular}{|c|c|c|c|}
\hline Category/application & GS SSCs & SS SSCs & SC SSCs \\
\hline \multirow[t]{2}{*}{$\begin{array}{l}\text { Structural including concrete } \\
\text { and equipment skids }\end{array}$} & $\begin{array}{l}\text { PC-2 (UBC Zone 2B); AISC; } \\
\text { ACI-318; AWS-D1.1 }\end{array}$ & Same as GS & $\begin{array}{l}\text { ANSI-N690; ACI-349; } \\
\text { PC-3 }\end{array}$ \\
\hline & \multicolumn{3}{|c|}{$\begin{array}{l}\text { Guidance on applicable codes and standards is also provided by Performance } \\
\text { Category per DOE-STD-1021. }\end{array}$} \\
\hline Equipment anchorage & PC-2 (DOE-STD-1021) & Same as GS & PC-3 (DOE-STD-1021) \\
\hline $\begin{array}{l}\text { Process equipment - } \\
\text { vessels and tanks }\end{array}$ & $\begin{array}{l}\text { ASME VII; API; } \\
\text { AWWA-D100; UL-58, }-142\end{array}$ & Same as GS & ASME III ${ }^{2}$ \\
\hline $\begin{array}{l}\text { Process equipment - } \\
\text { piping and valves }\end{array}$ & $\begin{array}{l}\text { ANST/ASME B31.1, B31.3, } \\
\text { B31.5, B31.9, B-16 series }\end{array}$ & Same as GS & ASME III'; ANSI-N278 \\
\hline $\begin{array}{l}\text { Process equipment - } \\
\text { pumps and compressors }\end{array}$ & $\begin{array}{l}\text { ANSI/ASME } 373.1 \mathrm{M} \text {, 2M; } \\
\text { ASME VIII; Hydraulic Institute } \\
\text { Standards; AWWA; AFBMA }\end{array}$ & Same as GS & ASME III ${ }^{2}$ \\
\hline $\begin{array}{l}\text { Process equipment - } \\
\text { heat exchangers }\end{array}$ & ASME VII; TEMA & Same as GS & ASME III \\
\hline $\begin{array}{l}\text { Process equipment - } \\
\text { hoods and ducts }\end{array}$ & $\begin{array}{l}\text { ASHRAE; SMACNA; ACGIH; } \\
\text { ANSUAASME NS09, N510 }\end{array}$ & Same as GS & Same as GS \\
\hline $\begin{array}{l}\text { Process equipment - } \\
\text { pre- and HEPA filters }\end{array}$ & $\begin{array}{l}\text { ASHRAE-52.68, } \\
\text { ANSI/ASME N509, N510; } \\
\text { Mil-F-51068C, ERDA 76-21; } \\
\text { ASME AG-1 }\end{array}$ & Same as GS & Same as GS \\
\hline Electrical & NFPA 70 (NEC); NESC & IEEE-577 & IEEE-603 \\
\hline Instruments and controls & $\begin{array}{l}\text { ISA-S5.1,S5.4,S18.1,S20, } \\
\text { NUREG } 0800\end{array}$ & Same as GS & IEEE-603 - \\
\hline Fire protection - hydrogen & NFPA & Same as GS & Same as GS \\
\hline Industrial hygiene hazards & $\begin{array}{l}\text { OSHA; AICHE Safety } \\
\text { Standards; API Safety } \\
\text { Standards; ACGIH } \\
\text { Requirements }\end{array}$ & Same as GS & Same as GS \\
\hline Health physics & $\begin{array}{l}10 \mathrm{CFR} 830, \text { ANSU/ANS } \\
\text { HPSSC } 6.8 .1, \text { ANSI } 57.7 \\
\text { ANSI N13.6, N13.15, N42.17A } \\
\text { and B, N323, NCRP } 57 \text { and } 58\end{array}$ & Same as GS & Same as GS \\
\hline All applicable equipment & $\begin{array}{l}\text { OSHA; UL; Local and State } \\
\text { Standards; AWS; NEMA; } \\
\text { ASTM; ANSI }\end{array}$ & Same as GS & Same as GS \\
\hline
\end{tabular}

"ASME Section III or provide justification that ASME Section VIII or ASME B31.3 is appropriate for the system being designed.

${ }^{b}$ ANSI-N278 or provide justification that ASME-B-16.xx or B-31.3 is appropriate for the system being designed.

$\mathrm{GS}=$ general services.

HEPA = high-efficiency particulate air (fifter).

$\mathrm{SC}=$ safety class.

SS = safety significant.

$\mathrm{SSC}=$ structure, system, and component. 
6.1.1.3 Instrumentation and Control. The following design requirements shall be applicable to instrumentation and control equipment designs for all systems in Chapter 6.0.

- Local electronic transmitters for remote indication shall be provided and shall include local indication, whenever possible. For example for flow indication, a flow-indicating transmitter shall be used.

- For major electrical equipment a local control station shall be provided. A switch shall be provided to allow for Hand (local on), OFF, and Remote (from the MCS). When this switch is taken out of Remote, a notification shall be provided to the control room.

- Engineering units shall be used wherever possible. The use of $0-100 \%$ range indication shall be avoided. The range of equipment shall cover both the expected normal range as well as upset, emergency and faulted if the instrument would be used under these conditions.

- Instruments shall have the capability to be calibrated without the need to open the fluid boundary. The use of wells, isolation valves and test ports shall be utilized whenever possible.

- Panel design shall consider the likelihood of surface radioactive contamination and water sprays. In location where this possibility exists, the use of watertight enclosures shall be used.

- Panels larger than $203 \mathrm{~mm}$ ( $8 \mathrm{in}$.) in length or height shall utilize hinged door covers. For all instrument racks, the access doors shall be removable.

- The use of hardwired interlocks shall be appropriate to the condition being protected against. For the most part MCS interlocks shall be utilized (software interlocks), however, for the protection of personnel or equipment that can result in significant damage, hard interlocks may be used.

- Standardization of the selection of instrument and control equipment is critical to maintenance and cost-effectiveness. All common items within the CVDF shall be the same make and model whenever possible.

- The need for "emergency off" buttons shall be reviewed, documented and implemented based on the impact to personnel, equipment or program goals. The implementation of this function may be hardwired or performed by the MCS via local switches. For example, the PWC has a requirement for an emergency off switch due to the potential of contaminated water spray, in this case the MCS will be utilized to perform this function. Note that an emergency off button performs a different function that the local off control switch, the emergency button shall be a mushroom type switch allowing for rapid activation. 


\subsubsection{Safety Functional Requirements}

The general safety functional requirements from Chapter 3.0 are summarized and listed in Table 6-1. Table 6-1 assigns these safety functional requirements to the appropriate safety systems and components in this section.

All SSCs required to perform the safety functions of these systems shall be classified as either safety-significant or safety-class. The safety classification will require the assignment of design codes and standards and quality assurance requirements commensurate with the classification. The design codes and standards selected for safety SSCs are listed in Table 6-2. Substitutions and/or additions to these selected codes and standards must be accompanied by justification for why the proposed substitution and/or addition can adequately satisfy the functional performance requirements of the SSC. The assigned codes and standards for all safety SSCs will be identified on the equipment list (see Appendix E).

Safety SSCs are composed either safety-significant or safety-class classifications (see Chapter 3.0 for classifications). The general design requirements listed below are applicable to all . safety-significant systems and components.

a. The safety-significant SSCs shall comply with design requirements in WHC-CM-4-46.

The general design requirements listed below are applicable to all safety-class systems and components.

a. The safety-class systems needed to meet the technical requirements described below shall comply with "safety class" in accordance with DOE Order 6430.1A (see Appendix A for applicable section requirements).

b. Safety-class systems must also comply with NRC equivalency requirements in accordance with Appendix B. The main NRC requirements are found in the IEEE Standard 603-1991, Standard Criteria for Safety Systems. These systems shall be "class 1E" in accordance with IEEE 603-1991. Although this is a guide, elements of this and other referenced American National Standards Institute and IEEE standards within IEEE 603-1991 shall be followed to the extent applicable. Where applicability evaluations are required, full documentation shall be provided.

\subsubsection{Testing, Surveillance and Maintenance Requirements}

All equipment shall be designed to optimize testing, surveillance and maintenance to maximize system and component reliability, availability and maintainability goals established (see Section 6.1.1.2 for goals) and minimize operational staff workloads. As a goal, general services process equipment shall avoid or minimize regularly scheduled tests, surveillances and maintenance activities. Safety equipment regularly scheduled testing, surveillance, and 
maintenance shall be designed for minimum impact on facility availability and staffing requirements.

The safety-significant systems or components shall be designed for testing, surveillance, and maintenance in accordance with higher reliability goals as identified in each systems safety design requirements. The safety-significant systems components shall be under administrative control for all testing, surveillance, and maintenance activities. All activities shall be performed under controlled procedures.

The safety-class systems shall be designed for testing, surveillance, and maintenance in accordance with IEEE Standard 603-1991 (IEEE 1991). The safety-class systems shall be under administrative control for all testing, surveillance, and maintenance activities. All activities shall be performed under controlled procedures.

6.1.3.1 Testing. Testing features shall be designed to implement testing requirements. Functional performance criteria for SSCs shall be identified and tested on a periodic basis to ensure operability of systems and components. Safety system and component functions and minimum operability criteria shall be identified and tested on a regular schedule (monthly) or additional testing schedule if required by surveillance failures, testing failures, or after maintenance. All testing shall be accomplished between MCO processing cycles, with the exception of process specific tests, and shall have minimum impact on processing availability. Only standard approved and controlled testing procedures and equipment shall be used.

6.1.3.2 Surveillance. System design shall incorporate features for verifying system operability. Operability will be verified by surveillance of the system's operability status and component states before enabling the system.

6.1.3.3 Maintenance. There shall be no regularly scheduled facility shutdowns for maintenance. Regularly scheduled maintenance activities shall be avoided in the selection of equipment or materials in the design. The system maintenance activities shall be limited to maintenance due to failures. Where maintenance may be required, the system design shall incorporate features and requirements for ease of maintenance and replacement of parts to maintain high system availability. Additional maintenance activities and procedures may be scheduled if system testing, surveillance, or maintenance identifies additional maintenance needs. All maintenance shall be performed under controlled procedures using approved (Quality Assurance-qualified) equipment and materials. Only spare parts meeting design criteria shall be procured and used.

\subsubsection{Environmental Qualification}

All general services components shall be designed to operate under normal environmental conditions. The normal environmental conditions are listed in Table 6-3. 
Table 6-3. Environmental Qualification Requirements for General Services, Safety-Significant and Safety-Class Structures, Systems, and Components.

\begin{tabular}{|c|c|c|c|c|c|c|c|c|c|}
\hline \multirow{3}{*}{ No. } & \multirow{3}{*}{ Plant state } & \multicolumn{8}{|c|}{ Service conditions } \\
\hline & & \multicolumn{4}{|c|}{ Extemal } & \multirow{2}{*}{$\begin{array}{c}\text { Internal } \\
\text { contamination }\end{array}$} & \multirow{2}{*}{ Radiation } & \multirow{2}{*}{ Vibration } & \multirow{2}{*}{ Duty cycle } \\
\hline & & Temperature & Pressure & Humidity & Contamination & & & & \\
\hline 1 & Normal conditions & $40^{\circ} \mathrm{F}-130^{\circ} \mathrm{F}$ & Ambient & $0 \%-100 \%$ & Dirt/dust & System Specific & $\begin{array}{l}\text { System } \\
\text { location } \\
\text { specific }\end{array}$ & $\begin{array}{l}\text { Frequency } \\
\text { (TBD) }\end{array}$ & Time in use \\
\hline 2 & Upset conditions & $\mathrm{NC}$ & $\mathrm{NC}$ & $\mathrm{NC}$ & $\mathrm{NC}$ & $\mathrm{NC}$ & $\mathrm{NC}$ & NA & NA \\
\hline 3 & Contamination release & $\mathrm{NC}$ & $\mathrm{NC}$ & $\mathrm{NC}$ & $\begin{array}{l}\text { Dirt and dust } \\
\text { radiation }\end{array}$ & $\begin{array}{l}\text { Dirt and dust } \\
\text { radiation }\end{array}$ & NC & NA & NA \\
\hline 4 & $\begin{array}{l}\text { Loss of power, cooling, } \\
\text { or HVAC }\end{array}$ & $130^{\circ} \mathrm{F}$ & $\mathrm{NC}$ & $\mathrm{NC}$ & $\mathrm{NC}$ & $\mathrm{NC}$ & $\mathrm{NC}$ & NA & NA \\
\hline 5 & $\begin{array}{l}\text { Process equipment } \\
\text { explosion }\end{array}$ & NC̣ & $\mathrm{NC}$ & NC & $\mathrm{NC}$ & $\mathrm{NC}$ & $\mathrm{NC}$ & NA. & NA \\
\hline 6 & Fire & $\mathrm{NC}$ & $\mathrm{NC}$ & $100 \%^{3}$ & Smoke & Smoke & $\mathrm{NC}$ & NA & NA \\
\hline 7 & Seismic event & $130^{\circ} \mathrm{F}$ & $\mathrm{NC}$ & $\mathrm{NC}$ & $\mathrm{NC}$ & NC & $\mathrm{NC}$ & NA & NA \\
\hline 8 & $\begin{array}{l}\text { Tornado and high } \\
\text { winds }\end{array}$ & $130^{\circ} \mathrm{F}$ & $\mathrm{NC}$ & $\mathrm{NC}$ & $\mathrm{NC}$ & $\mathrm{NC}$ & $\mathrm{NC}$ & NA & NA \\
\hline 9 & Floods & $130^{\circ} \mathrm{F}$ & $\mathrm{NC}$ & $\mathrm{NC}$ & NC & $\mathrm{NC}$ & NC & NA & NA \\
\hline
\end{tabular}

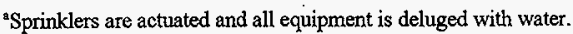

$\mathrm{HVAC}=$ heating, ventilating, and air conditioning.

$\mathrm{NA}=$ not applicable.

$\mathrm{NC}=$ normal conditions.

$\mathrm{TBD}=$ to be determined. 
All safety components shall be designed to function under worst-case internal and external environmental conditions. These conditions are composed of design basis events and process upset event plant conditions identified in Section 3.5.2 and the associated internal and external environmental conditions listed in Table 6-3. Safety detection or protection shall be provided where the design cannot guard against these impacts. The design shall mitigate those conditions that represent a potential common-mode failure of the safety function, and documentation shall be provided for those mitigation features.

\subsubsection{Seismic Qualification}

All equipment shall be assigned either to seismic PC-2 for general services and safetysignificant functions or to $\mathrm{PC}-3$ for safety-class functions in accordance with the seismic design requirements in Section 3.3.8, Section 3.4.7 and Tables 3-6 and 3-7.

All equipment within the process bays with the potential, because of seismic-induced failure, of preventing safety-class SSCs from performing safety-class functions shall be anchored for the design basis seismic PC-3 criteria in accordance with WHC-SD-GN-DGS-30006, Guidelines for Assessing the Seismic Adequacy of Existing Performance Category Equipment at the Hanford Site. Seismic design requirements for all SSCs shall be assigned and documented in the equipment list (see Appendix E).

\subsubsection{Fuman Factors}

Human factors consideration in the design of DOE facilities is required in DOE Order 6430.1A, Section 1300-12.4 (see Appendix A for applicable requirements). DOE has a draft standard, "Human Engineering Design Criteria, Volume I," that shall be used as a guideline for evaluating human factors considerations of the CVDF design. In addition, NRC equivalency (see Appendix B) requires that NUREG-0700, Human System Interface Design Review Guidelines, and NUREG-0800, Standard Review Plan, Section 18.1, "Human Factors Engineering, Control Room," be reviewed for additional applicable requirements above the $D O E$ guidelines. Application of these guidelines shall be documented for the appropriate human factors interfaces (man-machine interfaces) of the safety-class SSCs. These include, but are not limited to, the following interfaces and activities:

- Operations interfaces (operator activities and task analysis)

- Process water tank room operations review

- Process bay operations review 
- Control interfaces for normal, upset, and emergency or faulted conditions for

- Control room interfaces

- Process bay local controls and panels

- Testing, surveillance, and maintenance activities.

\subsection{CIVIL DESIGN REQUIREMENTS}

\subsubsection{Location, Boundaries and Interfaces}

6.2.1.1 Location. The CVDF will be located at the $100 \mathrm{~K}$ Area of the Hanford Site and shall be sited adjacent to the $105 \mathrm{~K}$ East and $105 \mathrm{~K}$ West Fuel Storage Facilities. The location is inside the $800-\mathrm{m}(0.5-\mathrm{mi})$ eagle-roost buffer zone but outside the $400-\mathrm{m}(0.25-\mathrm{mi})$ line-of-sight restrictive distance.

\subsubsection{Interfaces.}

a. Several site upgrade projects, including utility expansions, are planned to be accomplished concurrent with construction of the CVDF. The CVDF design shall consider these related projects and ensure integration with the CVDF. The Operating Contractor shall provide a list of these upgrade projects.

b. The current $100 \mathrm{~K}$ Area service water system will be extended to provide an adequate water supply to the CVDF fire suppression systems and fire protection loop.

c. The current $100 \mathrm{~K}$ Area potable and service water system shall be extended to provide adequate service to the CVDF.

\subsubsection{Facility Functional Requirements}

a. The site shall include construction of the necessary parking, maneuvering, and transport roads, site drainage structures, security fencing, and sidewalks.

b. The site shall be surveyed and mapped using the Washington State coordinate system. Designs for paved roads shall conform to Washington State Department of Transportation M-41.1. The design shall be based upon current and projected usage.

c. All concrete design shall comply with American Concrete Institute (ACI) requirements. 


\section{HNF-SD-SNF-DRD-002 REV 1}

d. The site design shall include features to satisfy the Storm Water Pollution Prevention Plan requirements of 40 CFR 122.44 (National Pollutant Discharge Elimination System). These features shall include those deemed appropriate to control erosion; runoff, and sedimentation during construction of the CVDF. The detailed design shall support filing of the Notice of Intent and writing the Storm Water Prevention Plan.

e. Underground conduit installations shall be in compliance with the National Electrical Code (NEC), Article 300-5.

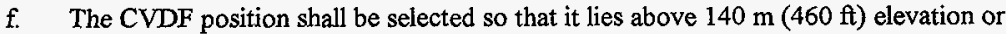
site features shall be constructed to ensure that flooding cannot result in release of nuclear material from the CVDF.

\subsubsection{Safety Functional Requirements}

a. The site drainage systems shall be designed to handle the design basis rainfall runoff detailed in Section 3.3.8.

\subsubsection{Facility Performance Requirements}

a. Actual elevations and coordinates shall be shown on drawings and shall be determined from the ground control system currently in use.

b. The site shall be provided with a permanent bench mark and coordinate monument for future reference.

c. No landscaping is required other than grading and clearing the area around the facility.

d. The paved areas shall be capable of supporting a tractor-trailer with an approximate weight of $47,600 \mathrm{~kg}(105,000 \mathrm{lb})$.

e. Parking spaces for four passenger vehicles shall be provided at the facility entrance.

f. Where excavations are backfilled during construction of utilities, the material used, the method of placement, and the level of compaction shall be specified to provide adequate support and to allow drainage.

g. The backfill around a pipe shall be of a material that will not damage the pipe.

h. Specifications for excavation work shall require that excavations comply with the Hanford Contractors Industrial Health and Safety Manual. 
i. All outside circuits for power, telephone, Hanford Local Area Network, and electrical services shall be placed underground when practicable.

j. $\quad 110 \mathrm{~V}$ ac power supply shall be provided on the west side of the CVDF for the nearfield air monitor.

k. A sanitary sewage drainage system shall be required for the CVDF. The system shall be self-contained and provide for pumping of its holding tank into a sewage pick-up tanker truck.

1. The concrete floor and parking slabs load shall be a be capable of supporting a tractor-trailer weighing approximately $47,600 \mathrm{~kg}(105,000 \mathrm{lb})$.

m. To facilitate surface drainage, all areas adjacent to the building shall have a $1 \%$ minimum slope away from the building if areas are paved and $2 \%$ if unpaved.

n. Concrete slabs, door stoops, and truck ramps shall be sloped at least $2 \%$ where feasible.

o. Splash pads shall be provided below roof drains and gutters.

p. Exterior concrete slabs (e.g., sidewalks, door stoops) shall be given a broom surface finish, or equivalent, to minimize the safety hazard of slipping during freezing weather conditions.

\subsubsection{Safety Performance Requirements}

a. The site drainage systems shall be designed to handle the design basis rainfall runoff defined in Section 3.3.8. An analysis shall be documented to demonstrate compliance with requirements. The design basis local runoff requirements are given in WHC-SD-SNF-DB-010, Section 5.2.1 (Tallman 1996).

\subsubsection{Codes and Standards}

The codes and standards applicable to the design of SSCs are listed in Table 6-2. 


\subsection{STRUCTURAL DESIGN REQUIREMENTS}

\subsubsection{Location, Boundaries and Interfaces}

- Location

The CVDF shall consist of the following collocated structural systems:

The CVDF process building consisting of

- Process bays area

- Transfer corridor and mechanical room area

- Process water tank room

The CVDF administration area

Process equipment systems within the CVDF.

- Boundaries and interfaces

There shall be distinct structural boundaries between PC-2 and PC-3 structurai interfaces. PC-3 SSCs shall be isolated from the effects of PC-2 SSC failures such that the PC-3 safety functions can still be accomplished under design basis conditions.

\subsubsection{Facility Functional Requirements}

The process bays shall house the cask-trailer and all of the process systems except the PWC system. The process water tank room shall house the PWC system. The transfer corridor shall provide access areas and support areas to the process bays and house support and/or utility systems and equipment. The mechanical room shall house and/or support utility systems, equipment, and HVAC systems.

\subsubsection{Safety Functional Requirements}

The following are the safety function requirements summarized from Chapter 3.0, Table 3-7 (see Chapter 3.0 for further descriptions of these safety functions):

- Secondary confinement (contaminated effluents from primary process confinement releases)

- Radiation protection (ALARA from cask-MCO and primary process confinement contaminated effluents)

- Fire protection 
- NPH mitigation (seismic, tornado and high winds, floods)

- Worker safety hazards protection (industrial safety and industrial hygiene).

The process bays and process water tank room form the safety-significant secondary confinement boundary for confinement of contaminated effluents from the process primary confinement. The design of these enclosures shall minimize holdup and accumulation of contaminants to reduce the radiation exposure of the system to ALARA. The structures and components shall provide protection against industrial hazards for protection of the workers. Those SSCs relied upon during a seismic event to maintain structural integrity for protection of safety-class SSCs are classified as PC-3. Those SSCs relied upon to protect safety-significant SSCs or the workers are classified PC-2. The facility SSCs safety-significant secondary confinement function is not required to be functional after a seismic event (the process primary confinements are relied upon for a seismic event).

\subsubsection{Facility Performance Requirements}

6.3.4.1 Structural Systems. The CVDF shall consist of the following structural systems:

- The CVDF process building consisting of

- Process bays area (PC-3)

- Transfer corridor and mechanical room area (PC-2)

- Process water tank room (PC-3)

- The CVDF administration area (PC-2)

- Process equipment systems within the CVDF.

6.3.4.1.1 Cold Vacuum Drying Facility Design Life Requirement. The CVDF is to be a temporary structure. The scheduled duration for processing all the K Basins SNF is 2 years. The design life of the facility shall be 5 years to allow for unplanned processing duration extension.

6.3.4.1.2 Structural Design for Demolition. The CVDF structural design shall be selected to facilitate demolition of the facility and recycling of the structural materials when the CVDF's temporary mission is completed. All-steel construction is to be preferred for this purpose except where lesser cost radiation shielding may be achieved using concrete panels attached to the steel frame. Cast-in-place concrete systems are to be avoided wherever adequate structural performance can be achieved by other means. 
6.3.4.1.3 Building Structural Materials. The structural systems shall be constructed from one or more of the following materials unless design dictates the use of other materials or strengths:

- Reinforced concrete

Compressive strength $\left(\mathrm{f}_{\mathrm{c}}\right)=3,000 \mathrm{lb} / \mathrm{in}^{2}$ minimum

Reinforcing steel - ASTM A615 (fy $\left.=60,000 \mathrm{lb} / \mathrm{in}^{2}\right)$

Welded Wire Fabric - ASTM A185

- Carbon steel

Structural steel - ASTM A36/A36M (Fy $\left.=36 \mathrm{lb} / \mathrm{in}^{2}\right)$

Structural tubing - ASTM A500 Grade B (Fy $\left.=46 \mathrm{lb} / \mathrm{in}^{2}\right)$

Steel pipe - ASTM A53 Type E or S Grade B (Fy $=35 \mathrm{lb} / \mathrm{in} 2)$

Welding material - AWS D1.1, E70XX electrode

- Bolts, nuts, and washers

Common bolts - ASTM A307

High-strength bolts - ASTM A325

Nuts - ASTM A563

Hardened washers - ASTM F436.

Refer to American Society for Testing and Materials specifications for specific material requirements. For miscellaneous materials, such as metal deck, grating, floor plate, crane rails, see the respective project construction specification sections or detailed drawings.

\subsubsection{Physical Design Criteria.}

\subsection{Normal Building Loads.}

Dead Loads. Dead loads include the gravity load of structures, permanent equipment, piping, static liquid, soil, long-term stored materials, permanent partitions, and any other permanent static load. Dead-load criteria for the CVDF are given in GC-LOAD-01.

Live Loads. Live loads are the loads superimposed on structures or components by the use and occupancy of the facility. Live loads, in general, include the weight of movable objects such as personnel, temporarily stored materials, movable partitions, maintenance equipment, forklifts, hoists, and cranes. Live-load criteria for the CVDF are given in GC-LOAD-01.

Snow Load. Snow-load criteria, as specified in WHC-SD-SNF-DB-010, shall be the criteria given in ASCE-7, Chapter $8\left(98 \mathrm{~kg} / \mathrm{m}^{2}\left[20 \mathrm{lb} / \mathrm{ft}^{2}\right]\right)$. 
Thermal Loads and Creep and Shrinkage. Self-straining forces and effects arise from restraint of expansion or contraction due to temperature change, shrinkage, creep, or differential settlement. These forces shall be considered in the facility design. All structures and items exposed to the exterior environment shall be designed for a maximum daily temperature of $50^{\circ} \mathrm{C}$ $\left(120^{\circ} \mathrm{F}\right)$ and a minimum daily temperature $-30^{\circ} \mathrm{C}\left(-20^{\circ} \mathrm{F}\right)$ (HNF-S-0435, Section 4.4). The effects of thermal gradients due to the difference between the internal and external temperatures in massive concrete members or structures shall be taken into account in accordance with Appendix A of ACI 349. The minimum linear coefficient of shrinkage will be assumed to be $0.0002 \mathrm{in} / \mathrm{in}$ in accordance with DOE Order 6430.1A.

6.3.4.2.2 Natural Phenomena Loads. The design basis natural phenomena loads and conditions that are to be applied to the CVDF structural design are tabulated in Table 1 of WHC-SD-SNF-DB-010. These criteria are applied to SSCs based upon the PC-2 (for essential facilities) or PC-3 classification.

Wind and Tornado. Straight wind load and missile load criteria are given in WHC-SD-SNF-DB-010, Chapter 3. Tornado wind speed and pressure drop loads for the CVDF also are given in WHC-SD-SNF-DB-010, Chapter 3. Tornado missiles have been eliminated from the CVDF requirements.

Earthquake Loads. DBE loads and spectra are given in WHC-SD-SNF-DB-010, Section 2.2 .

Ashfall Loads. The design requirements for ashfall are given in WHC-SD-SNF-DB-010, Section 2.2. The CVDF does not have PC-4 SSCs or safety components that must be active after a design basis ashfall.

Flood Loads. The design basis river flood level, assuming a $25 \%$ breach of Grand Coulee Dam, is $140 \mathrm{~m}(460 \mathrm{ft})$. This is $5 \mathrm{~m}(16 \mathrm{ft}$ ) below the CVDF elevation (WHC-SD-SNF-DB-010, Chapter 5.0). No action is required.

Earth and Groundwater Loads. Earth and groundwater load requirements are given in GC-LOAD-01 (Paragraph 6.5). Dynamic earth pressures shall be considered in the design of PC-3 below-grade structures.

\subsection{Load Factors and Load Combinations.}

6.3.4.2.3.1 Load Combinations and Stress Limits. The CVDF building shall be designed to adequately resist the effects of various load combinations. The governing documents in determining load combinations for PC-3 structures are as follows:

- Dead load, live load, and accident load combinations

- ACr 349-90 for reinforced concrete

- AISC/ANSI N690 for structural steel 
- Seismic and wind load combinations

- DOE-STD-1020-94 for both reinforced concrete and structural steel

- ACI 349-90 for reinforced concrete.

- $\quad$ AISC/ANSI N690 for structural steel.

6.3.4.2.3.2 Reinforced Concrete Design. The following load combinations shall be used to determine the demand on reinforced concrete members of the CVDF building:

1. $\mathrm{D}_{\mathrm{e}}=1.4 \mathrm{D}+1.7 \mathrm{~L}+1.7 \mathrm{H}$

2. $\mathrm{D}_{\mathrm{c}}=\mathrm{D}+\mathrm{L}+\mathrm{H} \pm \mathrm{T} \pm \mathrm{E}$

3. $\mathrm{D}_{\mathrm{c}}=0.9\left[\mathrm{D}+\mathrm{L}+\mathrm{H}+\mathrm{T}+\mathrm{W}_{\mathrm{t}}\right]$

4. $\mathrm{D}_{\mathrm{e}}=\mathrm{D}+\mathrm{L}+\mathrm{H} \pm \mathrm{E}$

5. $\mathrm{D}_{\mathrm{e}}=\mathrm{D}+1.3 \mathrm{~W}$

6. $\mathrm{D}_{\mathrm{e}}=1.05 \mathrm{D}+1.3 \mathrm{~L}+1.3 \mathrm{H}+1.05 \mathrm{~T}$

7. $\mathrm{D}_{\mathrm{e}}=1.4 \mathrm{D}+1.7 \mathrm{~L}+1.7 \mathrm{H}+1.7 \mathrm{~W}$

8. $\mathrm{D}_{\mathrm{c}}=1.05 \mathrm{D}+1.3 \mathrm{~L}+1.3 \mathrm{H}+1.3 \mathrm{~W}$

where

$\mathrm{D}_{\mathrm{e}}=$ demand

$\mathrm{D}=$ dead load including collateral dead load where it produces the more critical condition

$\mathrm{L}=$ live load, including applicable crane impact loads, snow load

$\mathrm{T}=$ normal operational thermal load

$\mathrm{W}=$ wind load

$\mathrm{W}_{\mathrm{t}}=$ wind load due to tornado

$\mathrm{E}=$ earthquake load

$H=$ earth pressure load.

Where any load reduces the effects of other loads, the load factor for that load shall be taken as zero, unless that load can be demonstrated as always present and in such a case, the load factor shall be taken as 0.9 .

6.3.4.2.3.3 Structural Steel Design. The following load combinations shall be used to determine the demand on structural steel members of the CVDF building. 


\section{Load Combination}

1. $\mathrm{D}_{\mathrm{e}}=\mathrm{D}+\mathrm{L}+\mathrm{L}_{\mathrm{T}}+\mathrm{T}$

2. $\mathrm{D}_{\mathrm{e}}=\mathrm{D}+\mathrm{L}+\mathrm{L}_{\mathrm{T}}+\mathrm{T} \pm \mathrm{E}$

3. $\mathrm{D}_{\mathrm{e}}=\mathrm{D}+\mathrm{L}+\mathrm{L}_{\mathrm{T}}+\mathrm{T} \pm \mathrm{W}$

4. $\mathrm{D}_{\mathrm{c}}=\mathrm{D}+\mathrm{L}+\mathrm{L}_{\mathrm{T}}$

5. $\mathrm{D}_{\mathrm{c}}=\mathrm{D}+\mathrm{L}+\mathrm{L}_{\mathrm{T}} \pm \mathrm{E}$

6. $\mathrm{D}_{\mathrm{c}}=\mathrm{D}+\mathrm{L}+\mathrm{W}$

7. $\mathrm{D}_{\mathrm{e}}=\mathrm{D}+\mathrm{L}+0.5 \mathrm{~L}_{\mathrm{s}}+\mathrm{W}$

8. $\mathrm{D}_{\mathrm{c}}=\mathrm{D}+\mathrm{L}+\mathrm{L}_{\mathrm{s}}+0.5 \mathrm{~W}$

9. $\mathrm{D}_{\mathrm{e}}=0.85 \mathrm{D}+\mathrm{W}$

10. $\mathrm{D}_{\mathrm{c}}=\mathrm{D}+\mathrm{L}+\mathrm{L}_{\mathrm{T}}+\mathrm{W}_{\mathrm{t}}$
Stress Limit Coefficient ${ }^{d}$

$1.0^{\mathrm{a}}$

$1.6^{\mathrm{b}}$

$1.5^{\mathrm{c}}$

$1.6^{b}$

$1.7^{\mathrm{b}}$

1.33

1.33

1.33

1.33

1.6

where all symbols have the same meanings as above except soil pressure, $\mathrm{H}$, which shall be combined with live load in the combinations above, and

$\mathrm{L}=$ Live loads, including applicable crane impact loads, but excluding snow or roof live loads

$\mathbf{L}_{\mathrm{T}}=$ Larger of roof live load or snow load.

All load combinations shall be checked for the no live-load condition.

a. For primary plus secondary stress, the allowable limits are increased by a factor of 1.5 .

b. The stress limit coefficient in shear shall not exceed 1.4 in members and bolts.

c. Secondary stresses that are used to limit primary stresses shall be treated as primary stresses. In no instance shall the allowable stress exceed $0.70 \mathrm{~F}_{\mathrm{u}}$ (in axial tension $0.7 \mathrm{~F}_{\mathrm{u}}$ times the ratio $\mathrm{Z} / \mathrm{S}$ for tension plus bending: $\mathrm{F}_{\mathrm{u}}$ is the specified minimum tensile strength of the material; $Z$ is the plastic section modulus; and $\mathrm{S}$ is the elastic section modulus).

d. Stress limit coefficients are applied to primary stress limits given in Sections Q1.5.1, Q1.5.2, Q1.5.3, Q1.5.4, Q1.5.5, Q1.6, Q1.1.0 and Q1.11 of AISC/ANSI N690.

6.3.4.3 Foundation. The foundation shall be designed to support the structure and to keep differential settlements within acceptable limits. Frost depth is a maximum of $0.8 \mathrm{~m}(30 \mathrm{in}$.) below grade. Allowable basic soil bearing pressure shall be $24,400 \mathrm{~kg} / \mathrm{m}^{2}\left(5,000 \mathrm{lb} / \mathrm{ft}^{2}\right)$ based on the Shannon and Wilson Report (1435-01).

6.3.4.4 Building Backfill. Backfill, such as around building foundations and under slabs, shall be compacted to a minimum of $95 \%$ of maximum density (depending upon type of structure and load requirements) at optimum moisture content levels. Soil shall be compacted in layers not exceeding $200 \mathrm{~mm}(8 \mathrm{in}$.) in thickness. 
6.3.4.5 Roof Decks. Metal roof decks shall be constructed, for fire protection purposes, as Class I with these restrictions.

- Insulation shall be of fiberboard, fiberglass, or foam glass materials.

- The vapor barrier material shall be noncombustible.

- Factory Mutual Data Sheet 1-28S and the Factory Mutual Approval Guide shall be used for acceptable materials selection and construction practices. (This last requirement applies only to the administration and PWC tank rooms).

\subsubsection{Safety Performance Requirements}

6.3.5.1 Facility Classification. The CVDF process building is classified as a nonreactor nuclear facility according to DOE Order 6430.1A, Section 1300. The CVDF Preliminary Safety Evaluation (WHC-SD-SNF-PSE-003) has determined that the CVDF will be a hazard category 2 nuclear facility according to the guidelines of DOE-STD-1027-92.

The office area shall be a nonnuclear facility rated for general use in accordance with the UBC (ICBO 1994).

\subsubsection{Confinement Capabilities.}

a. The CVDF shall be constructed so that it has two confinement structures. Primary confinement shall be accomplished by the MCO and the drying system piping and equipment that will be connected to it.

b. The primary confinement shall prevent release of radioactive material into the interior of the CVDF process bays under normal operational and upset conditions.

c. Secondary confinement shall be accomplished with the partitions that define each process bay. The secondary confinement shall block release of radioactive material into the environment outside the facility in the event that the primary confinement fails. The structures that shall be considered to be part of the secondary confinement are the walls, floors, and roof that define each of the process bays, the ventilation system exhaust HEPA filters and the duct work section leading from the HEPA filter housing through the confinement wall, the isolation damper and inlet duct work through the confinement wall, and the structures that hold these key ventilation system structures.

d. The process water tank room and each individual process bay shall be tested for leak rate in accordance with ASTM E-779-87, Standard Test Method for Determining Air Leakage Rate by Fan Pressurization. The test shall be conducted to determine the natural air infiltration rate using the Lawrence Berkeley Laboratory model (ASHRAE Handbook of Fundamentals) for calculating effective leakage areas and estimated 
natural infiltration rates. Infiltration leakage sources shall be identified and sealed and the building retested until leakage is ALARA.

6.3.5.3 Seismic Analysis and Design. The seismic design and analyses are given independent assessments. For PC-3 and safety-class SSCs, it is provided by a party completely uninvolved in the project. For PC-2, it is provided by an engineering check performed by a qualified professional, not necessarily removed from the project. The criteria include input definition, response determination approach, performance requirements, and seismic design considerations. These criteria are based primarily on the guidelines provided by DOE-STD-1020-94, TM 5-809-10-1, and UBC.

6.3.5.3.1 Building Structure Earthquake Loads. Performance categories determined in accordance with DOE-STD-1020-94 are defined for the safety SSCs in Section 6.3.4.1. PC-3 DBE loads are defined in Section 6.3.4.2.3. There is no operating basis earthquake for the CVDF.

a. PC-2 earthquake loads shall be those given by UBC for seismic zone $2 B$ for essential facilities (DOE-STD-1020-94).

b. The CVDF shall be designed for passive safety. Achievement or maintenance of the safe shutdown condition shall not require action by energized components. No small-magnitude, near-field earthquake analysis need be performed.

c. The administration building shall be structurally decoupled from the process bay structure and designed to fail away from the bay during a PC-3 event.

6.3.5.3.2 Damping. For purposes of elastic dynamic analysis taking into account spectral damping values, the damping coefficients given in DOE-STD-1020-94, Table 2.3, shall be used. The response level 3 damping values shall be used as directed by DOE-STD-1020-94, Section C4.4.1.

6.3.5.3.3 Inelastic Energy Absorption. Inelastic absorption factor values, $F_{w}$ are to be taken from DOE-STD-1020-94, Table 2-4. The maximum spectral acceleration shall be used for fundamental frequencies greater than the frequency at which the peak spectral acceleration occurs when $\mathrm{F}_{\mathrm{u}}>1.0$.

6.3.5.3.4 Ground Motion Components. Three ground acceleration components shall be considered (two horizontal and one vertical). Combination of direction components shall comply with ASCE 4.

\subsection{Analysis Procedures.}

a. PC-3 SSCs shall be subjected to a dynamic analysis. Dynamic analysis of the CVDF building structure shall be an elastic response spectrum analysis using a commercially available finite element code. The extent and detail of structural models shall be 
consistent with obtaining realistic structural response of items to be analyzed within an engineering degree of accuracy.

b. Modeling of items shall be conducted to the detail required to ensure obtaining the actual response and shall be consistent with the method of analysis being used. For dynamic analysis, the model shall be, as a minimum, a lumped-mass system interconnected by elastic elements.

c. The models must adequately represent the physical characteristics of SSCs and their corresponding responses to seismic excitations. Where it is difficult to model various SSCs, parametric studies are required to determine sensitivity of the model to various parameter changes (e.g., mass, stiffness, material properties). Refining the model is then done to reflect the appropriate parameter representation as determined by the studies.

d. All physically connected SSCs shall be represented as a combined single mathematical model unless such connected SSCs are permitted to be uncoupled by the following considerations. All physically connected SSCs are coupled to some degree and should be modeled accordingly. However, for purposes of simplicity and economy, in many cases it is desirable and sufficiently accurate to separate models of structural systems into two or more individual parts. Models of structural systems may be uncoupled according to the following general guidelines.

There are two distinct types of coupling conditions:

- Where SSCs are coupled together but supported independently, the coupled point may be considered as an additional support point.

- Where the SSCs are physically coupled and physically support one or another through the coupling point, one being the primary support.

All other coupling conditions are combinations of these two types of sampling conditions.

Basically, uncoupling can be justified where the model of each subsystem or subcomponent is developed to account for interaction effects at interfaces or where it is shown that the dynamic response of subsystems and subcomponents is independent as modeled.

The response spectrum technique requires modal analysis of the structure to determine its natural frequencies and the corresponding mode shapes. The dynamic characteristics of the structure are used in the calculation of structural response such as displacements, forces and moments, and stresses due to externally applied seismic forces as defined by the amplified response spectra. The modal analysis will include all 
significant modes of the structure with frequencies below the cut-off frequency. In addition, the analyst is required to demonstrate that the analysis accounts for the inertial effects of modes above the cut-off frequency.

When uncoupling is justified, the subdivided SSCs will be modeled in a consistent manner. When SSCs are subdivided and, as a result, become supported structures, care must be taken in providing the input motion that is representative of the seismic response of the supporting structure.

For efficient modeling, geometric, mass, and reflective symmetry may be utilized to reduce the number of degrees-of-freedom. However, care must be taken to ensure that significant translational and rotational degrees-of-freedom are considered at mass points. In addition, consideration must be given to the coupling effects that may occur between the translational and rotational degrees-of-freedom where the center of mass and center of resistance (for either torsional and bending effects) do not coincide.

Analytic techniques will account for the effect of horizontal torsional moments due to actual and accidental eccentricities between centers of mass and rigidity at each level.

Inclusion of accidental torsion accounts for such factors as spatial variations of horizontal input motions applied to long buildings, rotational components of ground motions, the effects of nonstructural elements or building stiffness and inertial characteristics, the actual distribution of dead and live loads, uncertainties in defining the building's material properties for dynamic analysis, and variations in foundation-soil coupling effectiveness.

In addition to the horizontal torsion induced by the eccentricity of the calculated center of mass from the calculated center of rigidity, an additional torsion resulting from an accidental eccentricity will be considered in accordance with Section 3.3.1.2 of ASCE 4-86. The required accidental eccentricity is equal to $5 \%$ of the building dimension measured perpendicular to the direction of the lateral force. The accidental torsion takes into account several factors including the possibility of non-vertical propagation of seismic waves.

Where torsional irregularity exists as specified in the UBC, the effects will be accounted for by increasing the accidental torsion by an amplification factor: Torsional moments are to be resisted by the structure's lateral force-resisting system and the resulting torsional member shear forces added to direct shear forces by standard analytical methods.

At foundations or points of support, the rocking degrees-of-freedom should be considered in the mathematical model. Although, in some cases, such degrees-of-freedom are insignificant, care should be taken to justify their elimination. 
Discontinuities that may exist in an SSC (e.g., drastic changes in stiffness, gaps, or clearances) that become part of the mathematical model may require special consideration. It may be necessary to treat gap or clearance discontinuities as nonlinearities, and such discontinuities may be subject to impact forces. An appropriate mathematical procedure for representing the response of such gaps or clearances will be used in determining the impact forces for design purposes. In addition, at points of rapid changes in stiffness, attention should be focused on stress risers.

When modeling equipment, the mathematical model should represent the equipment in its operational mode if it must remain in operation to maintain its required function.

The following special considerations are applicable to items supported by other structures rather than being directly supported on ground. Where a supported item has two or more response frequencies that exist within the broadened resonant frequency band of the supporting point response spectrum, the spectrum may be modified in the analysis to prevent unnecessary conservatism. Since the supporting SSC can have only one resonant frequency, the broadened spectrum is modified such that its peak corresponds to one of the supported substructure, subsystem, or subcomponent frequencies within the broadened range as described in RDT F 9-2. The supported substructure, subsystem, or subcomponent is analyzed using the supporting spectrum modified as shown once for each frequency in the broadened band. For example, if three frequencies of the supported substructure, subsystem, or subcomponent were in the broadened band, there would be three analyses, and the analysis producing the largest total response would be used for the design.

For the condition where a substructure, subsystem, or subcomponent is supported by more than one supporting SSC, there will be differing response spectra at various support points. These support point spectra will be superimposed on each other, and the design spectrum for the substructure, subsystem, or subcomponent taken as the upper bound envelope of the support point spectra considered.

PC-2 structures shall be structurally designed and analyzed in accordance with the static equivalent procedure given in $U B C$ for seismic zone $2 B$, essential facilities.

\subsection{Soil Structure Interaction.}

a. A fixed-base seismic analysis shall be performed because the building foundation is shallow. Soil structure interaction (SSI) shall be accounted for by peak broadening in the high frequency range. This is consistent with the criteria given in DOE-STD-1020-94 where it is stated that it is permissible to ignore the beneficial effects of SSI and assume that the DBE ground motion applies to the foundation level of the structure provided that any frequency shifting due to SSI is considered. 
b. An SSI analysis shall be performed based on site soil properties extracted from WHC-SD-W236A-TI-002, Probabilistic Seismic Hazard Analysis, DOE Hanford Site, Washington. This will ensure the fixed-base analysis is bounding. A fixed-base analysis neglects the benefits of foundation scattering and radiation damping. The effects of rocking modes are excluded in this approach but are small for short buildings such as the CVDF.

c. Verification that the peak broadening approach for accounting adequately for SSI is appropriate shall be achieved by extending soil properties data given in WHC-SD-W236A-TI-002.

An allowable soil bearing pressure of $24,400 \mathrm{~kg} / \mathrm{m}^{2}\left(5,000 \mathrm{lb} / \mathrm{ft}^{2}\right)$ (Shannon and Wilson Report [1435-001]) shall be used in the analysis.

6.3.5.3.7 Seismic Acceptance Criteria. The resulting seismic forces for each element are reduced by the inelastic demand-capacity ratio $\left(F_{v}\right)$ to obtain the inelastic seismic demand, which is then combined with other loads in accordance with Section 6.3.4.2.3 to determine the total demand for the element. The capacities of the elements are obtained from code allowable ultimate or yield values. Once the capacity of an element is computed it is compared to the total demand for that element.

For steel, the capacity is taken to be the stress limit coefficient times the ANSI N690 elastic capacity for allowable stress design or can be taken to be the plastic capacity per AISC (M016) Chapter N. For concrete, the American Concrete Institute ultimate strength capacities will be used. Note that strength reduction factors, $f$, are retained.

Inherent to the acceptability of this procedure is the ability to develop ductility levels comparable to those achieved through the use of the UBC's design and detailing requirements.

\subsubsection{Seismic Qualification of Equipment.}

6.3.5.4.1 In-Structure Response Spectra. Design in-structure response spectra (ISRS) are required as input for structure-supported PC-3 items such as substructures, equipment, or piping (DOE-STD-1020-94).

a. Such ISRS shall be developed by one of two methods: time history or modified Singh. Requirements for the methods are described below.

1. Raw ISRS developed for locations shall be smoothed and peaks broadened according to procedures described in the NRC's Regulatory Guide 1.122.

In order to limit the number of ISRS required for design or qualification of supported items, it is appropriate to envelop spectra generated from various response point locations to create design ISRS. When generating ISRS, care must be taken to include response contribution from all input directions. 
Combination of components will be in accordance with Section 2.2.5.5 of DOE-STD-1020-94.

Time-history generation is essentially a modal time-history response analysis with appropriate models to accurately develop time-history response at key support point locations. The support motions are then to be used for generation of raw spectra that are then enveloped, smoothed, and broadened to provide ISRS suitable for design purposes.

2. The generation of raw spectra shall use an acceptable response spectrum generation method similar to that used for generation of ground spectra. ISRS generation and development shall meet the general requirements of the NRC Regulatory Guide 1.122.

3. In the modified-Singh method, ISRS are generated directly from design spectra, which provide input criteria for supporting structures. Required enveloping, smoothing, and broadening shall conform to the criteria of NRC Regulatory Guide 1.122 .

4. When using the modified-Singh approach, one spectrum at each level shall be calculated using both time-history and the modified-Singh methods. Comparison of the raw spectra shall be made to provide assurance that all aspects of the modified-Singh analysis have been properly carried out.

A method for approximating a design floor response spectrum is presented in Chapter 6 of TM 5-809-10-1.

6.3.5.4.2 Stability Requirements. All items shall be designed to resist the overturning and sliding effects caused by earthquake loads. Items shall be positively anchored to supporting structures or foundations.

At the interface of major structure foundations with soil, the stability ratio for overturning and sliding will be 1.0 for DBE loads. The stability ratio for overturning is the ratio of the dead load resisting moment and the earthquake-induced overturning moment. The sliding stability ratio is the ratio of applicable resisting forces (e.g., fractional and passive earth loads) and the maximum horizontal earthquake forces applied to the structure in a given direction at the foundation soil interface.

6.3.5.4.3 Safety-Class Active Component Qualification. The CVDF design method is to achieve and maintain safe shutdown without the use of active components. However, the supply air isolation dampers, the exhaust isolation dampers, and the components in the SCHe purge system must change to their fail-safe positions and must perform their passive functions. These items shall be qualified following the PC-3 qualification guidelines given in DOE-STD-1020-94, Section 2.4-1, either by laboratory testing in accordance with IEEE-344 or by acceptance of data drawn from an approved earthquake experience database (SAND92-0140.UC-523, Generic 
Implementation Procedure (GIP) for Seismic Verification of Nuclear Plant Equipment, Seismic Qualification Utility Group, 1991).

\subsection{Equipment Mounting.}

a. Equipment anchorage requirements shall be as defined in DOE-STD-1020-94, Section 2.4.1, and in WHC-SD-GN-DGS-30006.

b. Equipment supports shall be designed to avoid resonance resulting from the harmony between the natural frequency of the structure and the operating frequency of reciprocating or rotating equipment supported on the structure.

c. The operating frequency of supported equipment shall be determined from manufacturer's data before completion of structural design.

d. Where economically practical, resonance shall be prevented by designing equipment isolation supports to reduce the dynamic transmission of the applied loads. Isolation supports shall be designed for seismic events.

e. Anchor bolts and expansion anchors for safety-class and safety-significant items shall be designed in accordance with the guidelines contained WHC-SD-GN-DGS-30006, Chapter 4.0, and in Appendix A.

f. Anchor bolts and expansion anchors for non-safety class and non-safety significant items shall conform to UBC requirements and industry standards with allowable loads and installation according to CV-9, Installation of Wedge Expansion Anchors.

g. Piping systems shall be mounted according to the guidance of WHC-SD-GN-DGS-30006.

h. Piping supports shall be rigid members that are fastened to building structural members by bolted or welded joints. They shall surround the pipes so that pipes may not fall off the support in the event of an earthquake. Pipe supports shall not be so rigidly attached to pipes as to restrain the motion of long runs of pipe.

i. Threaded and bell and spigot joints are not to be used. Welded and bolted flanged connections are acceptable.

j. Small piping or tubing ( 1 in. or less) shall not be used to support eccentric masses such as motor- or air-operated valves. Supports should be located at the locations of these eccentric masses. Supports shall not be placed on the valve operator without additional support of the valve body or the pipe immediately adjacent to the valve. The valve body and operator shall be supported on a common structure. 
k. Expansion joints shall be laterally supported. Support spacing shall not exceed the distances given in Table 3.4 of WHC-SD-GN-DGS-30006.

1. No seismic analysis shall be required for piping systems where the weight of sections between supports is less than $20 \mathrm{lb}$ according to Table 2.7 of WHC-SD-GN-DGS-30006.

m. Sprinkler system shall be restrained per NFPA 13.

6.3.5.5 Shielding Capabilities. Should concrete be used for radiation shielding, the design shall comply with ACI 349 .

6.3.5.6 Subsurface Investigation. A subsurface investigation shall be performed as required for critical facilities (including radioactive material handling facilities) by DOE Order 6430.1A, Section 201-1. The data shall be used to verify conservative assumptions made in the foundation design and in analyzing SSI effects in the seismic analysis.

\subsubsection{Fire Resistance.}

a. Fire resistance requirements and types of construction shall be in accordance with the UBC criteria for fire-resistant materials used in the design and construction of fire-resistive designs as listed in the Underwriters Laboratories (UL) Fire Resistance Directory.

b. Fire resistance ratings will be based on UBC criteria and the improved risk criteria defined by DOE Order 6430.1A, DOE Order 5480.7A and RL Directive 5480.7. This includes the separation of adjacent noncompatible groups by 2 -hour fire barriers.

\subsubsection{Codes and Standards}

The codes and standards that apply to the structural design of the CVDF are listed in Table 6-2.

\subsection{ARCHITECTURAL DESIGN REQUIREMENTS}

\subsubsection{Location, Boundries, and Interfaces}

The CVDF will be a facility constructed at the $\mathrm{K}$ Basin site within a few hundred yards of the basins, as determined in the evaluation recorded in WHC-SD-SNF-SE-001, Cold Vacuum Drying Site Evaluation Report. It shall have process bays in which transport trailers can be contained while the free water is drained and a vacuum and helium purge process dries the SNF. 
The CVDF shall have a support area where there will be a control room, change rooms, and other functions required to support and coordinate operations.

The CVDF building shall be a steel frame structure on a concrete pad located on the $\mathrm{K}$ Basin site. The site location is close to the $\mathrm{K}$ Basins, near utility lines, and outside a nearby eagle-roosting area. The building plans shall include independent bays where transport trailers will be parked and processed. The number of bays shall be based on process time and the desired throughput. Truck access to each bay will be through overhead doors.

\subsubsection{Facility Functional Requirements}

a. The CVDF shall be a temporary facility. The planned duration to process the entire $\mathrm{K}$ Basins SNF inventory is 2 years. Therefore the design lifetime for the facility is 5 years.

b. The features of the CVDF shall be selected with the intent of creating a structure that can be dismantled and recycled with relative ease or that can be reconfigured for an unspecified, future alternative use with relative ease.

c. The building code requirements shall be met as defined in the UBC for a Group $\mathrm{H}-7$ occupancy for the process bay and support areas and a Group B occupancy for the administrative office areas. Exiting requirements shall conform to NFPA 101, Life Safety Code. The facility is classified as special purpose industrial per NFPA 101. The facility classification criteria shall also conform to requirements established in DOE Order 6430.1A, Section 0110-99 for special facilities (Nonreactor Nuclear Facilities), and Section 1320 (Irradiated Fissile Material Storage Facilities).

d. The facility is exempt from accessibility requirements because of the operation requirements.

e. The design of the facility and materials utilized shall conform to 10 CFR $835.1002 \mathrm{~d}$ as providing features allowing operations, maintenance, decontamination, and decommissioning.

f. All masonry and concrete design shall comply with the current UBC, $\mathrm{ACI} 318$, ACI 349, and Precast Concrete Institute standards.

g. Insulation shall comply with the provisions of DOE-RL Architectural Engineering Standards, Section 5.3.6. 


\subsubsection{Safety Functional Requirements}

a. Fire doors shall be provided as required by the Fire Hazards Analysis, WHC-SD-SNF-FHA-003, Preliminary Fire Hazards Analysis for the Cold Vacuum Drying System Facility, the UBC, NFPA-80, and NFPA-101.

\subsubsection{Facility Performance Requiirements}

a. These bays shall be connected by a common corridor. The corridor allows personnel access through step-off pads, as well as acting as a chase for service header piping and conduits. Personnel shall enter the building through the support area at the end of the building where there shall be facilities for changing, bathrooms, lunch, and control of the building activities.

b. Bay walls shall be precast concrete panels; similar panels shall be used to provide shielding around the process water tank room. All other interior walls shall be painted gypsum board over steel studs.

c. Mechanical systems that shall be distributed to each bay include chilled water, compressed air, firewater, PWC, and gases.

d. Each bay shall be served by a dedicated ventilation system that will circulate and HEPA-filter the air, as well as exhaust process exhaust and vent streams and air collected from a hood at the top of the MCOs. These exhausts shall be collected in a stack that will be monitored to detect radioactive emissions.

e. There shall be no sanitary sewer connection to the CVDF. Sewage will be collected in a tank and transferred to a tanker truck that will haul it to a sewage treatment plant offsite.

f. Process water shall also be collected in a tank, processed, and transferred to a tanker truck periodically.

g. The process water and sanitary waste handling systems require space allotment within the CVDF that is accessible to trucks.

h. All facilities shall be designed to support both sexes. For design purposes, the personnel requirements are as shown below:

- 15 people

Single-shift operation (1.67 MCOs/week)

One 8-hour shif/day, 7 days/week, 7 employees/shift 
- 45 people

Three-shift operation (5 MCOs/week)

Three 8-hour shifts/day, 7 days/week, 7 employees/shift.

i. Each process bay shall provide ground floor space for enclosing a cask transporter without the tractor attached, access to the working level of the cask transporter, and access to the vacuum drying module equipment and pump assemblies.

j. Bridge crane access shall be provided to remove the cask lid and perform maintenance on equipment

k. A cabinet for supplies and a health physics work table shall be provided.

1. Radiological control shall be provided between a process bay and the access corridor where operators change clothing and are monitored for radiological contamination prior to admittance to the access corridor

m. Access to the working level of the cask shall be accomplished using a mezzanine level with space to the working level of the cask transporter for connections to the cask, access to the HVAC equipment, and process hood assembly

n. A single decontamination room shall serve all process bays. The space shall accommodate clear standing space for the decontamination process, storage of decontamination materials and detection equipment, and one decontamination shower.

o. A swipe/count room shall be provided to analyze and store samples taken from process bays or areas that have the potential for contamination. The room will be sized to accommodate a lab bench work space with desks and associated instrumentation equipment, equipment storage space, and wall space for the mounting of gas bottle equipment

p. Space shall be provided for the air compressor.

q. A room shall be provided to house the security equipment

r. A room shall be provided in the process area to store supplies.

s. Process water removed from the MCO shall be collected, processed, and stored in tanks located in an isolated room with controlled access.

t. An administrative area shall be provided to control personnel access into the CVDF and provide for the following spaces and activities: 
u. Training/conference room

- Space for seating 12 people

- Refrigerator space for 15 people's meals

- Two microwave ovens

- Casework with sink and storage.

v. Engineering Support

Work space for two persons with desks and associated equipment shall be provided.

w. Shift manager

Work space for one person with desks and associated equipment shall be provided.

x. Health physics technician and radiation monitoring

Work space for one health physics technician with desks and associated equipment shall be provided.

y. Control room

A space shall be provided for process bay control room functions. The space shall hold, at a minumum, computer monitoring stations, security monitor, communications, Hanford Local Area Network, annunciator, SCI\&C equipment operator panels, and furniture.

z. Electrical and telecommunications room

Space shall be provided for electrical and telecommunication systems and equipment .

aa. Fire riser room

Space shall be provided for fire riser equipment.

bb. Men's and women's restrooms

Restroom facilities shall be provided for both men and women employees. This function should be close to the respective change rooms

cc. Men's and women's change rooms

- Men's shower facilities

- Women's shower facilities 
- Men's and women's storage lockers and benches

- Space for change room supplies storage.

dd. Access and egress control and personnel control monitoring of the process bays.

ee. All transporter access doors shall be telescoping-type, fully weather-stripped, and shall be electrically operated with manual override. The wind pressure is $98 \mathrm{~kg} / \mathrm{m}^{2}$ $\left(20 \mathrm{lb} / \mathrm{ft}^{2}\right)$.

ff. Occupied spaces shall be suitably lighted and ventilated for safe habitation at all times.

gg. All fire doors and frames shall meet and be installed in accordance with all requirements of NFPA 80 and NFPA 101 and shall bear the UL or Factory Mutual label. Fire doors and frames shall be constructed from metal. All fire doors shall be provided with fitted frames that are anchored to, but separate from, the building structural members. The fire doors shall contain windows fitted with UL-approved, fire-resistant safety glass that is not removable from the outside of the door.

hh. All doors, except for the main administrative entrance door, shall be classified as emergency egress doors. Exterior doors and frames shail be constructed of metal and connected to the facility security system. All doors shall be provided with fitted frames that are anchored to, but separate from, the building structural members. All exterior doors separating heated spaces from the outside environment shall be fitted with UL-approved double glazing and door frames insulated with UL-approved insulating materials, which must meet fire rating requirements of the installation site.

ii. Doors that provide Zone II access, and selected egress doors, shall be equipped with windows, and equipped with automatic door closers.

ij. A minimum of 1.5 pairs of ball-bearing butt hinges ( 1.5 pairs $=3$ hinges) shall be provided on all doors.

kk. All door hinges shall conform to the latest issue of Federal Specification FF-H-116, or ANSI-A156.1 and ANSI-A156.7.

11. All doors requiring locks shall meet the latest issue of Federal Specification FF-H-106 as authorized by DOE, Richland Operations Office (RL).

$\mathrm{mm}$. Kick plates, $305 \mathrm{~mm}$ (12 in.) by door width, shall be provided on all external doors.

nn. All interior unpainted metal, such as trim, hardware, cabinets, and coverplates, shall be polished chrome, polished stainless steel, or anodized aluminum.

oo. All painted metal, such as trim and coverplates, shall be painted with an approved enamel or epoxy-based paint suitable for the use and environment. 
pp. All exterior metals to be painted shall be primed and painted in accordance with the standards developed by the National Association of Corrosion Engineers and the National Paint and Coating Association.

qq. Interior trim materials fabricated from plastic shall have a matte finish and the colors shall be coordinated with the interior color scheme.

rr. Materials of construction shall be limited to those known to exhibit flame-retardant properties and to minimize the production of toxic or otherwise hazardous smoke or particles if ignited.

ss. Exterior trim materials fabricated from plastic shall have a matte finish and the colors shall be coordinated with the exterior color scheme.

tt. Insulation shall be provided at the roof and walls of heated areas.

uu. Rigid insulation shall be provided at the foundation perimeter around administrative office area at a minimum of $0.6 \mathrm{~m}$ ( 24 in.) below grade.

vv. Vapor barriers shall be provided on the interior of exterior walls and on interior partitions adjacent to conditioned spaces that require humidity control.

$w w$. The minimum " $R$ " value for the roof overall insulation shall be 30 , for the walls, 24 .

$\mathrm{xx}$. Roofing shall comply with UBC Chapter 15 for roof construction and covering and UBC Chapter 16 for roof and wind design.

yy. The exterior roof of any of the secondary confinement area shall not leak water at $25 \mathrm{~Pa}(0.1$ in. w.g.) internal secondary pressure.

zz. The minimum roof slope shall be $1 / 4 \mathrm{in} . / \mathrm{ft}$.

aaa. The materials used will be noncombustible to the maximum extent possible.

bbb. Flashing shall be specified over doors, outside openings, and all wall and roof penetrations.

ccc. Cracks and joints in exterior walls shall have caulking and sealant to make the building airtight or watertight $\mathrm{A}$ single moisture medium silicone sealant shall be used on metal and glass surfaces. A polyurethane sealant shall be used on concrete surfaces.

ddd. Concrete surfaces within the process bays, including the floor and a $1.2-\mathrm{m}-(4-\mathrm{ft}$, 0-in.-) high wainscot on the precast wall faces shall be prepared to meet requirements for application of a decontaminable coating. 
eee. The CVDF shall be designated as an irradiated fissile material storage facility and shall meet the applicable requirements of DOE Order 6430.1A, Section 1320, and additional requirements contained herein.

fff. Accessway construction materials (e.g., gypsum board, wood, concrete) shall be completely covered with a sealant to reduce the surface permeability to air penetration.

ggg. Except for the process bays, floors throughout the facility shall have finishes appropriate to the area's function and flexibility requirements. In the process bays, exposed concrete floors shall have $100 \%$ solid epoxy surface that can be easily decontaminated.

hhh. Ferrous metals shall have one coat of metal primer and two coats of enamel. Galvanized metal shall have one coat of primer and two coats of enamel. Prefinished metal panel surfaces shall not be painted.

iii. An integral system of internal and external building signage shall be incorporated in the facility design. Graphics shall be in Helvetica medium type face.

jjj. Each bay shall include an overhead bridge crane with a capacity of $1,800 \mathrm{~kg}$ (4,000 lb). The crane shall be designed in accordance with the criteria included in CMAA 70. The bridge, trolley, and hoist shall be driven by electric motors and be capable of operation from the ground floor or mezzanine level.

\subsubsection{Safety Performance Requirments}

a. The maximum travel distance to any exit discharge shall be $46 \mathrm{~m}(150 \mathrm{ft})$ in accordance with NFPA 101.

b. Doors shall be operable from the inside without excessive force and without keys or special knowledge. The force requirements are $67 \mathrm{~N}(15 \mathrm{lbf})$ to release the latch, $133 \mathrm{~N}(30 \mathrm{lbf})$ to set the door in motion, and $67 \mathrm{~N}(15 \mathrm{lbf})$ to open the door to the minimum width.

c. Exitways shall be clearly marked and illuminated with an initial illumination of at least 1 foot candle (average) upon path of travel at all times.

d. Each bay shall include an overhead bridge crane with a capacity of $1,800 \mathrm{~kg}$ $(4,000 \mathrm{lb})$. The crane shall be designed in accordance with the criteria included in CMAA 70. The bridge, trolley, and hoist shall be driven by electric motors and be capable of operation from the ground floor or mezzanine level.

\subsubsection{Codes and Standards}


Codes, and standards that apply to the architectural design requirements of the CVDF are listed in Table 6-2.

\subsection{HEATING, VENTLATING, AND AIR CONDITIONING DESIGN CONSIDERATIONS AND STANDARD PRACTICES}

\subsubsection{Location, Boundaries and Interfaces}

This section describes the CVDF HVAC systems, locations, boundaries, and facility and process interfaces.

6.5.1.1 Location. The proposed CVDF location is in the $100 \mathrm{~K}$ Area, as described in Chapter 1.0 of this DRD. Design conditions for this location shall be obtained from GH-CLIM-01 (Hanford Site Climatic Data). A summary of conditions at the CVDF site is as follows:

- Latitude: $46^{\circ} 34^{\prime}$

- Longitude: $119^{\circ} 36^{\prime \prime}$

- Altitude: $476 \mathrm{ft}$

- Prevailing wind: NW

- Outdoor design temperatures: $+9^{\circ} \mathrm{F}$ winter; $97^{\circ} \mathrm{F} \mathrm{db}, 67^{\circ} \mathrm{F}$ wb summer

- Indoor design temperatures: $72^{\circ} \mathrm{F}$ winter, $75^{\circ} \mathrm{F}$ summer.

The CVDF HVAC systems shall locate the HEPA filtration as close as reasonably achievable to any expected airborne contamination sources. The filtration units and fans shall be located in the CVDF in a location designed to accommodate the equipment footprint and personnel egress and maintenance requirements.

6.5.1.2 Boundaries. The HVAC systems shall service the CVDF structural areas in accordance with confinement and safety classification requirements given to the process bays and $\mathrm{MCO}$ release collection.

6.5.1.3 Interfaces. The HVAC system interfaces shall be with facility compressed air to maintain temperature control, minimal balancing, and containment dampers. The HVAC system also interfaces with the facility or process MCS system. The HVAC control system shall provide the facility or process MCS, remote indication, alarms, and remote set points as required for the interfaces. The electric power distribution system is another interface with the HVAC system. Electric power distribution supplies three-phase $480 \mathrm{~V}$ ac or the supply and exhaust fans and the administration area air handling unit. The electric power distribution shall also supply any additional power requirements for all HVAC systems in the CVDF. Stack monitoring, reference air, chilled water, instrument air, fire protection, and building structural are other system interfaces. 


\subsubsection{Facility Functional Requirements}

Ventilation design shall comply with DOE Order 6430.1A, Sections 0110-12.4, 1161-4, 1300-7, and 1550. System design shall also comply with the applicable guidelines of the ASHRAE; ACGIH; Sheet Metal and Air Conditioning Contractors National Association; and the latest revisions of the ASME N509 nuclear air handling and filtration system construction, ASME N510 testing criteria, ASME AG-1 nuclear air cleaning system guidebook, and other state and federal regulations. The basic functional requirements for the HVAC systems shall be as follows.

a. The radioactive material within the CVDF shall be isolated from the environment by two levels of confinement. The primary confinement shall be achieved by the MCO, process piping, process water drain lines, PWC tanks, and so forth. Confinement performance is accomplished by using sealed structures (containment) without reliance upon air motion and filtration to manage the spread of radioactive material. The primary confinement shall be contained within the process bays and the PWC room. A rupture of the primary confinement shall allow a release into the secondary confinement volume. The spread of contamination from an accidental release in the secondary confinement volume shall be managed by the HVAC system serving the space.

b. Primary confinement of releases that may occur in the vicinity of the top of the MCO shall be accomplished with a hood that shall draw the air from the area around the top of the MCO into a duct leading to a primary exhaust system. The hood shall provide operator protection during connection and removal of the process connectors.

c. Office and operational areas shall be maintained at temperatures recommended by the appropriate codes and standards, as required by DOE Order 6430.1A, to ensure personnel comfort and safety and to protect equipment during normal and upset conditions.

d. . Pursuant to DOE Order 6430.1A, wherever feasible, air shall be filtered and recirculated for energy conservation. Otherwise $100 \%$ filtered and conditioned outside air shall be used for space ventilation.

e. Deliverable air quantities shall be provided to all areas sufficient to remove heat, hazardous and radioactive particulate matter and gases, and other contaminants.

f. Ventilation flows and pressure differentials will be detected and monitored throughout the facility as required to prevent the possible spread of hazards such as radioactive contamination. All confinement ventilation air flows and pressure differentials shall be alarmed if out of compliance.

g. Facility air flows shall be from areas of less contamination potential to areas of greater contamination potential. 


\section{HNF-SD-SNF-DRD-002 REV 1}

h. Cross contamination paths from one process bay area to another shall be prevented or HEPA filtered.

i. All confinement boundaries shall be sealed in the event of ventilation loss and/or zone pressure differentials loss except for penetrations that are provided with HEPA filters.

j. Exhaust ventilation systems shall be provided with HEPA filtration to minimize the release of hazardous materials through the exhaust path (DOE Order 6430.1A, Section 1550-2.5.5). All HEPA filtration design and construction practices shall conform to the guidelines of ERDA 76-21, Chapter 4; and ASME N509.

k. Radioactive materials shall be confined as close as practicable to the release point.

1. The system shall provide proper distribution of air flow throughout the facility during process normal, upset, and facility maintenance activities.

m. Provide an independent, stand-alone control system for the HVAC control system with interfaces (remote setpoints and remote indication as necessary) with the facility or process MCS capable of air flow control, fan speed adjustment, and pressure zone maintenance.

n. An interlocked HVAC control system shall be provided so that reversed air flow patterns cannot be established.

o. HVAC shall meet the requirements of NFPA 90A, Air Conditioning and Ventilating Systems, and NFPA 90B, Warm Air Heating and Air Conditioning Systems, shall be used as appropriate.

p. Fire dampers shall be tested in accordance with the requirements of ASTM E-119 and listed by UL or approved by Factory Mutual.

q. Sufficient access to and working space around HVAC equipment shall be provided to permit ready and safe operation and maintenance of such equipment. Access and working space shall be in accordance with supplier and International Conference of Building Officials code requirements.

r. Radionuclides, nonradioactive air pollutants, and toxic air pollutants shall be emitted through the exhaust stack. Radioactive air emissions and monitoring are governed by U.S. Environmental Protection Agency regulations at $40 \mathrm{CFR} 61$ and the Washington State regulations listed in WAC 246-247. Nonradioactive air pollutants are governed by the regulations listed in WAC 173-400. Toxic air pollutants are governed by regulations listed in WAC 173-460. All of these regulations specify emission limits, and they require the use of emission control technology. 
s. Filter plenums located inside process buildings should be separated from all parts of the building and enclosed by 2 -hour, fire-rated construction.

\subsubsection{Safety Functional Requirements}

The safety classification criteria for CVDF HVAC SSCs are given in Chapter 3.0 of this DRD. The application of the criteria to the CVDF SSCs yields the classifications provided in Table 6-4. The structural performance categories as defined by DOE-STD-1021-93 for the HVAC SSCs given in Table 6-4, as well as for items that have the potential for failure leading to damage of a safety-class item.

Table 6-4. Heating, Ventilating, and Air Conditioning System Design Requirements.

\begin{tabular}{|l|c|c|c|}
\hline \multicolumn{1}{|c|}{ Components } & $\begin{array}{c}\text { Safety } \\
\text { classification }\end{array}$ & $\begin{array}{c}\text { NPH } \\
\text { performance } \\
\text { category }\end{array}$ & $\begin{array}{c}\text { Environmental } \\
\text { qualification } \\
\text { (see Table 5-3) }\end{array}$ \\
\hline Fans & GS & PC-2 & 1 \\
\hline $\begin{array}{l}\text { HEPA filter and HEPA filter } \\
\text { housing }\end{array}$ & SS & PC-2 & 1 \\
\hline $\begin{array}{l}\text { Duct work and dampers before } \\
\text { HEPA filters }\end{array}$ & SS & PC-2 & 1 \\
\hline $\begin{array}{l}\text { Duct work and dampers after } \\
\text { HEPA filters }\end{array}$ & GS & PC-2 & 1 \\
\hline $\begin{array}{l}\text { Heat exchangers and heating and } \\
\text { cooling coils }\end{array}$ & SS & PC-2 & 1 \\
\hline Piping and valves & SS & PC-2 & 1 \\
\hline I\&C & GS & PC-2 & 1 \\
\hline Support structure & SS & PC-2 & 1 \\
\hline Stack & SS & PC-2 & NA \\
\hline
\end{tabular}

${ }^{1}$ This equipment is PC-3 if its failure can impact a PC-3 structure or prevent the proper operation of safetyclass functions.

\footnotetext{
$\mathrm{GS}=$ general services. HEPA = high-efficiency particulate air (filter). $I \& C=$ instrumentation and control. $\mathrm{NPH}=$ natural phenomena hazard. PC-2 = Performance Category 2.

$\mathrm{SS}=$ safety significant.
} 


\section{HNF-SD-SNF-DRD-002 REV 1}

The safety-class SSCs ensure that the exposure to the public at the site boundary is less than 25 rem per incident. See Table 6-4 for a listing. There are safety-significant SSCs that must function to ensure that onsite workers do not receive accidental doses in excess of the allowable limit. These are supply and exhaust isolation dampers. These components are required to close in the event of a loss of power and must meet the seismic performance criteria given in Section 6.3.5.3.1 of this DRD.

a. Single-failure analysis criteria shall be satisfied for all safety-class or safety-significant systems and/or components serving confinement areas required to maintain contamination control based on the results of the preliminary safety analysis report.

b. The CVDF shall be designed to maintain adequate confinement, defined as a condition that ensures that accidental releases from the primary confinement that may occur during a facility shutdown do not result in unacceptable dose consequences to onsite workers or offsite public. This is to be achieved by allowing the primary and secondary ventilation systems to go to an unpowered state in which all openings in the building structure are either closed or blocked by HEPA filters.

\subsubsection{Functional Performance Requirements}

a. The ventilation system shall meet all minimum deliverable air quantity requirements of ASHRAE Standard 62 and any other specific equipment requirements discussed in DOE Order 6430.1A, Sections 1550-2.5 and 1550-99.0.

b. The minimum deliverable air quantity of six air changes per hour, pending further hazard analysis, for all ventilation and exhaust air systems serving the confinement areas shall be provided.

c. Industrial ventilation design air quantities and transport velocities shall be calculated according to the calculation methods prescribed by the requirements in the ACGIH Industrial Ventilation Manual, ASHRAE Fundamentals, UBC, 29 CFR 1910, NFPA 45, NFPA 90A, NFPA 91, and NFPA 807. Design heating and cooling load calculations shall be developed and presented as part of the design packages.

d. Each process bay shall be served by an exhaust system that shall have sufficient capacity and standby functions to ensure an adequate controlled ventilation flow as required to contain contamination in the event of a credible breach in the primary confinement barrier.

e. The exhaust system shall control air flow and maintain a minimum negative pressure differential of $25 \mathrm{~Pa}(-0.1$ in. w.g.) in the bay with respect to its associated airlock and a minimum of $-50 \mathrm{~Pa}(-0.2$ in. w.g.) with respect to all other areas external to the secondary confinement barrier. 
f. Air from the process area support rooms shall also be exhausted into the HEPA filter exhaust system.

g. Confinement isolation dampers shall be provided on all duct branches connecting to the general exhaust system to prevent back flow in the event of exhaust system shutdown.

h. Exhaust air from the facility process area shall pass through a minimum of two HEPA filter stages before exhausting through the stack.

i. All secondary confinement primary and secondary exhaust openings in the building shall be equipped with backdraft dampers, isolation dampers, or HEPA filters that will block the flow of contamination out of the process building during a shutdown period.

j. The process bay air shall be continuously monitored for radioactivity.

k. Detection of radioactivity in the process bay room air shall initiate an alarm. In the event of a radiation alarm, the supply system shall continue to operate, recirculating air through the HEPA filters.

1. Fire dampers shall be provided only where closure will not prevent the functioning of safety-class systems in fire-rated separations necessary for confinement. Operation may be by thermal link or automatically from the fire protection system.

\subsubsection{Process Area Supply Air.}

a. The air in this system shall be $100 \%$ outside air shall be provided with filters rated at a minimum of $85 \%$ efficiency (atmospheric dust spot) in accordance with ASHRAE 62.

b. A confinement isolation damper shall be provided on the air intake to prevent backflow of air to the outside in the event of system shutdown.

c. Each process bay shall be served by a supply air system that recirculates a majority of the bay air to conserve energy.

d. Any recirculated air in the process area HVAC system shall pass through a minimum of two HEPA filter stages to control contamination.

e. Make-up air shall be supplied, as required, to maintain air quality in the bay at six air changes per hour.

\subsubsection{Process Area Exhaust System.}

a. An exhaust system shall be provided to serve all the process bay areas. 
b. The hood shall be custom designed with a minimum inlet face velocity of $0.64 \mathrm{~m} / \mathrm{sec}$ $(125 \mathrm{ft} / \mathrm{min})$ in accordance with the requirements of DOE Order 6430.1A, Chapter 11, and ACGIH Industrial Ventilation Manual hood design. The hood shall draw air away from the operator breathing space. The hood shall be mocked up and smoke tested to verify its capture capability before fabrication and installation in the facility.

c. The primary exhaust system shall be a stand-alone system with $100 \%$ exhausted air.

d. The primary exhaust system shall serve all the MCO process hoods and the process system exhaust and vent streams that may normally be contaminated, such as the vacuum pump exhaust, VPS condenser tank vents, PWC and TWS tank vents.

e. All process exhausts and vent streams shall be locally HEPA filtered before injection into the primary exhaust stream as practical.

f. The exhaust air treatment systems shall contain a HEPA filter train with a minimum of two HEPA filter stages or equivalent efficiency filtration, as required pending a safety analysis of offsite accidental exposure criteria. Each HEPA filter stage shall be testable to ASME N510 criteria.

\subsubsection{Process Area HEPA Filtration.}

a. HEPA filtration or equivalent filtration systems shall be used for areas handling potentially radioactive particulate to minimize the exposure to personnel or the environment.

b. HEPA filters and housings shall be fluid-seal, bag-in/bag-out type. The filter housings shall be fabricated from 304-L stainless steel with a 2-B mill finish. All filter housing joints and seams shall be welded and airtight when tested in accordance with ASME N510 at 1.25 times the rated fan capacity per ASME N509, or with ERDA 76-21, Table 5, whichever is more stringent. They shall be equipped with local differential pressure readouts and alarm high interfaces with the MCS to monitor the loading of the filters.

c. The number of exhaust filtration stages shall be sufficient to limit concentrations of airborne radioactive particulate released to the environment to less than the applicable limits at the point of discharge during all anticipated operating and DBA conditions.

d. The adequacy of the filtration system shall be confirmed by safety analysis to ensure that airborne radioactive particulate concentrations are ALARA and do not exceed DOE Order 5480.1A requirements during abnormal, accident, and DBA conditions.

e. HEPA filters shall have a minimum startup efficiency of $99.97 \%$ as evaluated by testing conducted in accordance with ASME N510. 
f. HEPA filters shall have a clean resistance pressure drop not to exceed $250 \mathrm{~Pa}$ (1 in. w.g.) with a velocity of the air entering the filter of $1.27 \mathrm{~m} / \mathrm{sec}(250 \mathrm{ft} / \mathrm{min})$.

g. HEPA filters shall be constructed and acceptance-tested in accordance with ASME N509, ASME N510, and ASME AG-1.

h. Air filtration housings shall be designed so that a tier of filters can be completely isolated from the ventilation system during filter element replacement, and they shall be designed and located with appropriate radiation protection to maintain occupational doses ALARA during operations and maintenance.

i. Air filtration units shall be installed as close as practical to the source of contamination to minimize the contaminated ventilation duct work (DOE Order 6430.1A, Sections 1300-11.2, 1550-99.0.2).

j. The air filtration housing design shall allow for routine in-place testing of HEPA filtration systems (filters, housings, and duct work) as outlined in ASME N510 (DOE Order 6430.1A, Section 1300-3.6).

k. HEPA filtration systems shall be designed with prefilters installed upstream of HEPA filters to extend the life of the HEPA filters.

1. The fire protection provided for the HEPA filter banks shall consist of thermal detectors installed upstream from the banks, fire screens, and isolation dampers in the duct work.

$\mathrm{m}$. The thermal detectors shall be the rate-compensated type connected to the fire alarm control panel and system exhaust fans. The temperature setting for the detector shall be $88^{\circ} \mathrm{C}\left(190^{\circ} \mathrm{F}\right)$ within $\pm 4.5^{\circ} \mathrm{C}\left(8^{\circ} \mathrm{F}\right)$. Upon detection, the fans shall be stopped and the dampers closed.

n. Automatic deluge spray systems should be designed in accordance with the applicable provisions of NFPA 13 and NFPA 15. The system should operate upon activation of fire alarm system heat detectors or pilot sprinkler heads. Manual activation should be provided as well.

o. Lighting and viewing ports, pursuant to ASME N509, should be provided inside the filter plenum in from or between the filter banks in the area where automatic and manual heads and nozzles are located. On and off switches should located outside the plenum at an accessible location.

p. All HEPA-fiitered systems shall be designed to ensure that proper airflow is maintained across the HEPA filter face and that the HEPA filters shall not operate in atmospheres above $70 \%$ relative humidity. Design considerations, supported by extensive calculations, to prevent filter blowout from high water entrainment are 
required. Pursuant to these considerations and calculations, a moisture sensing and control system shall maintain the filter face below $70 \%$ relative humidity or stop the system fans and alarm to the MCS indicating high filter face humidity. Also pending the calculations, HEPA filter housings (with and without deluge spray systems) shall be drainable and routed to a seal pot then to the PWC. The seal pots shall be equipped with level control system with low level alarms to the MCS to prevent filter bypass pursuant to ASME N509.

\subsubsection{Process Area Ductwork and Dampers.}

a. Design and installation of duct work and dampers shall comply with DOE Order 6430.1A, Section 1550-2.5.6, which requires compliance with NFPA 90A and Sheet Metal and Air Conditioning Contractors National Association.

b. Ducting systems shall be designed to minimize pressure drops through the system while maintaining the required entrainment velocities.

c. Fire dampers shall be provided in all supply return and exhaust air duct penetrations of fire-rated walls. Provisions shall be included for testing of dampers.

d. Exhaust ducts shall be sized for the transport velocities needed to convey all particulate without settling.

e. Velocities shall be determined in accordance with Section 5 of the ACGIH Industrial Ventilation Manual.

f. Duct thickness shall be determined by Tables 5.1, 5.2, 5.3, and 5.4 of ERDA 76-21. All welded duct work shall have a minimum duct thickness of No. 16 U.S. gauge.

g. All ducting systems shall be classified as determined by the criteria in ERDA 76-21, Table 5.5. Each duct system shall comply with the design and construction standards specified in ERDA 76-21 for the levels determined from Table 5.5. Acceptable leakage for each level of classification shall be no greater than the limits specified in Table 5.6 of ERDA 76-21.

h. Round duct work or pipe shall be used for the confinement exhaust system ventilation unless its installation is impractical.

i. Exhaust system duct velocities shall be maintained at a minimum of $10.2 \mathrm{~m} / \mathrm{sec}$ $(2,000 \mathrm{ft} / \mathrm{min})$ to provide proper entrainment.

j. Protective coatings shall be applied to the interior of exhaust duct work serving the confinement areas if other than stainless steel duct work is used. These coatings shall meet the requirements of ANSI N512 for "light exposure." 
k. Duct maintainability and testability shall follow the guidelines outlined in the ERDA 76-21, Section 2.3.8.

1. Duct cleanout provisions shall be included for all confinement duct work.

m. Adequate contamination control features and procedures shall be developed to perform duct cleanout operations.

n. Dampers shall comply with the requirements determined from Table 5.12 of ERDA 76-21. Duct systems serving the confinement areas of the facility shall not be acoustically treated.

o. Facility air balance shall be achieved through manually set dampers and variable frequency fans (as described below).

\subsubsection{Process Area Fans.}

a. Exhaust fans shall use variable frequency controlled motors that receive control signals from exhaust flow and/or pressure measurements.

b. Exhaust fan selection shall be based on the air change rates and pressure head calculated for the serviced areas or process cells.

c. Fan selection shall consider all anticipated normal operation, up-set, off-normal, and faulted conditions of the facility.

d. Fans shall be balanced and checked for harmonic vibration in accordance with ASME N509.

6.5.4.6 Exhaust and Stack Monitoring. All design requirements for exhaust stack monitoring are listed in Section 6.12.4.5, "Stacking Monitoring System."

a. An exhaust stack shall be provided for exhaust of all contaminated or potentially contaminated exhaust streams.

b. The stack shall be directly monitored for alpha emitting particulate and indirectly monitored for beta/gamma emitting particles and gases.

c. The monitoring equipment shall allow for both local and remote readout and alarm annunciation.

d. The stack monitoring system shall be provided with two monitoring systems that comply with DOE Order 6430.1A, Section 1589-99.0.1, "Radioactive Airborne Effluents," WAC-246-247-075, and ANSI N13.1, Guide to Sampling Airborne Radioactive Materials in Nuclear Facilities. 


\subsubsection{Administration Area Heating, Ventilating, and Air-Conditioning System.}

a. The administration area shall be conditioned with air from a dedicated air handling unit for this area.

b. Air shall be recirculated with make-up air to maintain indoor air quality per ASHRAE 62 and provide air for the change room and shower area exhaust system. Air from these areas shall be exhausted directly to the outside and not recirculated.

c. To prevent possible contamination, air in the rooms connecting the administration area to the process area shall not be exhausted to the outside, but directed towards the process area and the HEPA-filtered exhaust system.

d. The administration area shall be designed to remain at a positive pressure relative to atmospheric pressure or $12.5 \mathrm{~Pa}$ (+0.05 in. w.g.) during normal and atmospheric upset conditions.

e. Differential pressure monitoring and alarms for upset conditions shall be provided between the administration area and the process area to ensure the correct direction of air flow.

\subsubsection{Safety Performance Requirements}

The HVAC process area system shall passively confine all potential contamination within the secondary confinement of the system ductwork and HEPA filters. A failure-mode, effects, and criticality analysis shall be performed and documented to identify all fail conditions of the HVAC systems. As part of the failure-mode, effects, and criticality analysis results, detection and equipment fail safe controls and operating modes shall be provided for the system failure modes.

\subsubsection{Codes and Standards}

The codes and standards applicable to the design of SSCs are listed in Table 6-2.

\subsection{PIPED SYSTEMS}

\subsubsection{Location, Boundaries and Interfaces.}

a. The CVDF shall have mechanical systems consisting of piping distribution systems that deliver liquids and gases to support the vacuum drying processes and facility functions. All valves shall be operable from working levels. 
b. Service water and potable water are available from the existing $167-\mathrm{K}$ cross-tie tunnel north of the $165-\mathrm{KW}$ building. A service water line will be extended to the facility to provide water for fire protection, and a separate service water line will be extended to provide non-potable service to the CVDF. Potable water will be extended to provide potable water service for the change rooms, restrooms, janitors room, decontamination shower, safety showers, and eye washes.

c. Sanitary sewage will not be served by a sitewide sanitary sewage system. Instead, sanitary sewage generated in the CVDF shall be collected in a holding tank and transferred to a pumper truck designed to transport sewage.

d. Chilled water/cooling water, deionized water, compressed/instrument air, helium, reference air, stack sampling, and process floor drain systems shall be provided to service the CVDF. Pumps, tanks, separators, dryers, remote evaporator sections if required shall be located in the mechanical equipment area and piped to each process bay and piece of equipment that requires the services. Any air-cooled equipment and helium supply tanks shall be located outside the CVDF in close proximity of the mechanical equipment area.

e. All potentially contaminated piping systems shall be designed to ALARA principles. As a minimum, piping materials shall be easily decontaminated, construction methods should produce piping that is free of crevices and cracks, and shielding of the piped systems shall be considered.

f. For system interfaces see Table 6-5.

\subsubsection{Facility Functional Requirements}

a. Service water is required for the CVDF fire protection system, make-up water for all process systems, and for purification to provide deionized water. Backflow prevention is required between all systems and the service water.

b. Cold potable water shall be provided to supply sinks, water closets, urinals, showers, decontamination shower, custodial service sinks, drinking fountains, safety showers, eye wash stations, and decontamination showers. Hot potable water shall be provided to sinks, custodial service sinks, showers, and decontamination shower.

c. Sanitary sewer shall be provided for sinks, water closets, urinals, showers custodial service sinks, and drinking fountains. Drains are not required at safety showers or eye washes.

d. Chilled/cooling water shall be supplied to the HVAC cooling coils, TWS, and the vacuum pumping system in each bay. 
Table 6-5. Facility Systems Interfaces for the Cold Vacuum Drying Facility.

\begin{tabular}{|c|c|c|c|c|c|c|c|c|c|c|c|}
\hline \multirow[b]{2}{*}{ CVDF System } & \multicolumn{11}{|c|}{ Interfacing support system } \\
\hline & $\begin{array}{l}\text { Building } \\
\text { structures }\end{array}$ & $\begin{array}{l}\text { MCS and } \\
\text { control } \\
\text { room }\end{array}$ & $\begin{array}{c}480 \mathrm{~V} \text { ac } \\
\text { main power }\end{array}$ & $\begin{array}{c}120 \mathrm{~V} \text { ac } \\
\text { control } \\
\text { power }\end{array}$ & $\begin{array}{l}\text { HVAC } \\
\text { systems }\end{array}$ & $\begin{array}{l}\text { Instrument } \\
\text { air }\end{array}$ & $\begin{array}{l}\text { Helium } \\
\text { systems }\end{array}$ & $\begin{array}{l}\text { Service } \\
\text { water }\end{array}$ & $\begin{array}{l}\text { Deionized } \\
\text { water }\end{array}$ & $\begin{array}{c}\text { Cooling } \\
\text { water } \\
\text { system }\end{array}$ & $\begin{array}{l}\text { Water } \\
\text { sampling } \\
\text { and } \\
\text { analysis }\end{array}$ \\
\hline Service water & $\mathrm{x}$ & & & & $\mathrm{X}$ & & & $\mathrm{x}$ & $\mathrm{X}$ & $\mathrm{X}$ & \\
\hline Potable water & $\mathrm{X}$ & & & & & & & & & $\mathrm{X}$ & \\
\hline Sanitary sewer & $\mathrm{X}$ & & & & & & & & & & \\
\hline $\begin{array}{l}\text { Chilled/cooling } \\
\text { water }\end{array}$ & $\mathrm{X}$ & & & & $x$ & $\mathrm{X}$ & & $\mathrm{X}$ & & & \\
\hline $\begin{array}{l}\text { Deionized } \\
\text { water }\end{array}$ & $x$ & & & & & $\mathrm{x}$ & & $\mathrm{X}$ & & & \\
\hline $\begin{array}{l}\text { Compressed/ } \\
\text { instrument air }\end{array}$ & $\mathrm{X}$ & $\mathrm{X}$ & $\mathrm{x}$ & $\mathrm{X}$ & $\mathrm{x}$ & & & & & $\mathrm{x}$ & \\
\hline Fire protection & $\mathrm{X}$ & & & $x$ & & & & $\mathrm{X}$ & & & \\
\hline
\end{tabular}

$\mathrm{CVDF}=$ Cold Vacuum Drying Facility.

HVAC = heating, ventilating, and air-conditioning.

$\mathrm{MCS}=$ monitoring and control system. 
e. Deionized water shall be supplied to each process bay to supply the TWS and rinsing of the PWC system piping.

f. Compressed/instrument air shall be provided to each process bay to operate pneumatic tools, cask trailer leveling devices, and air-operated valves.

g. Helium is required to purge and dry the MCO. Helium shall be piped to each process bay for connection to the VPS and MCO.

h. A reference air system shall be used to allow reliable atmospheric pressure reference to control the differential pressure in the process bays.

i. A vacuum system shall be provided for process bay air sampling and exhaust stack sampling.

j. Floor drains are required in the process bays for firewater collection to prevent escape of liquids to the outdoors. These drains shall be routed to a storage tank located in a retention basin..

k. The CVDF requires a decontamination shower for personnel decontamination. A standalone shower is required with self-contained tank. (Refer to existing K Basin design per P.O. \#R6V-HHH-88259.)

\subsubsection{Safety Functional Requirements}

a. Piping for the CVD process performs the primary confinement for preventing the release of contaminants within the CVDF.

\subsubsection{Functional Performance Requirements}

\subsubsection{Service Water System.}

a. Service water is available for the fire sprinkler system, see Section 6.7 for requirements. Fire sprinkler service water shall be separate from the facility service water.

b. Service water shall be extended from the $167-\mathrm{K}$ cross-tie tunnel to provide all CVDF process water requirements. Service water will provide makeup water for the chilled/cooling water systems and as the source for deionized water. Reduced pressure backflow preventers shall be installed at all interface locations. All service water piping shall be designed and constructed in accordance with ASME B31.9. 


\subsubsection{Chilled/Cooling Water System.}

a. A central facility chilled water cooling system shall be designed to serve ventilation cooling loads, TWS heat exchangers, and the VPS condenser. The system concept shall include a packaged chiller units, circulating pumps, associated piping, instrumentation, and controls.

b. Chillers shall meet applicable American Refrigeration Institute standards and have the minimum controls specified in DOE 6430.1A, Section 1550-2.1.2.

c. Expansion tanks shall be designed to the ASME Code, Section VIII, and shall include gauge glasses, drain valves, vent valves, and pressure relief valves.

d. Make-up water shall be drawn from the service water supply through a reduced pressure backflow assembly.

e. All refrigerant piping shall be designed and constructed in accordance with ASME B31.5.

f. All chilled water piping shall be designed and constructed in accordance with ASME B31.9.

g. Chilled water shall be provided from the facility chilled water cooling system.

h. Chilled water shall not come in direct contact with process equipment surfaces (such as the $\mathrm{MCO}$ ) that might be contaminated.

\subsubsection{Deionized Water System.}

a. Deionized water shall be supplied to the process system via a packaged deionized water unit.

b. The deionizer unit shall be sized for a peak load of $38 \mathrm{~L} / \mathrm{min}(10 \mathrm{gal} / \mathrm{min})$ and an average load of $5,700 \mathrm{~L} /$ day $(1,500 \mathrm{gal} /$ day $)$.

c. The deionized water shall have a minimum resistance of $200,000 \mathrm{ohms}$.

d. The deionizer shall feed a plastic holding tank sized to accommodate peak loads and isolate the deionizer from possible contamination backflow and act as the process feed tank. Water shall be drawn from the service water supply through a reduced pressure backflow assembly.

e. Deionized water piping shall be designed and constructed in accordance with ASME B31.9. 
f. The resin shall be capable of handling an inlet concentration of $0.2 \mathrm{ppm}$ iron and $0.3 \mathrm{ppm}$ chlorine on the inlet side of the deionizer unit.

g. The deionizer unit shall produce at least $37,850 \mathrm{~L}(10,000 \mathrm{gal})$ of deionized water with a conductance of less than $5 \mu \mathrm{ohms}$ between changeouts.

h. The deionizer unit shall have a positive visual indication when the outlet conductivity exceeds $5 \mu \mathrm{ohms}$.

\subsubsection{Potable Water System.}

a. Potable water shall be supplied to the facility from an existing water main at the north side of the building from the 167-K cross-tie tunnel. A Reduced Pressure Principle backflow preventer shall be installed in CVDF.

b. Potable cold water shall be used to supply the safety eye washes, sinks, restrooms, custodial service sinks, drinking fountains, and decontamination shower. Hot water shall be supplied by tank-type electric water heaters.

c. There shall be no potable water lines in the process areas of the building except to serve eye washes and safety showers.

d. Eye washes and safety showers shall comply with ANSI Z358.1.

e. Potable water lines shall be sterilized in accordance with AWWA C652.

f. Potable water lines shall be designed and constructed in accordance with the Uniform Plumbing Code.

\subsubsection{Sanitary Sewage Collection System.}

a. The CVDF will not be served by a sitewide sanitary sewage system. Sanitary sewage generated in the CVDF shall be collected in a holding tank sited near the CVDF.

b. The tank shall be sized retain sewage generated by 45 persons per day. Fourteen persons will shower each day. The regular pumping schedule shall be twice per week. The tank shall be buried no deeper than required to provide gravity drain from the facility and to meet structural requirements.

c. There shall be no connections to the sanitary sewage system in the process areas of the CVDF.

d. The sanitary sewer plumbing shall be designed and constructed in accordance with the Uniform Plumbing Code. 
e. The sanitary sewage holding tank shall be designed and installed in accordance with WAC 246-272-12501.

\subsubsection{Condensate, Floor Drains and Firewater Collection.}

a. Each bay and fire zone in the building shall be equipped with floor drains for the purpose of collecting firewater should the sprinkler system activate. The facility floors must have dikes and slopes, and the drain size must be designed so that the buildup of water on the floor when the sprinklers are discharging at maximum rate cannot spill out of the CVDF. The firewater shall be assumed to be possibly contaminated.

b. Floor drains shall be designed to maintain confinement between process bays, transfer corridor, and the outdoors.

c. All of the fire discharge water shall be routed in a double-wall stainless steel piping system to an above-ground storage tank and retention basin located outside the facility. Piping shall be designed and constructed in accordance with the Universal Product Code and ASME B31.1.

d. The containment piping shall be routed to a monitoring sump where a spill discharge occurrences shall be detected. The spill containment monitoring box shall have a low-discharge opening to drain the retention basin.

e. The initial $757 \mathrm{C}$ (200 gal) of drainage shall be collected in a tank specified to meet American Water Works Association D100 requirements.

1) The tank shall be critically safe, the inside diameter shall be limited to $597 \mathrm{~mm}$ (23.5 in.).

2) The tank vent shall be HEPA filtered and vented into the building general exhaust system.

3) The purpose of the tank shall be to capture a batch of $\mathrm{MCO}$ water in the event of a process system failure.

4) The tank shall overflow into a firewater retention basin sized to collect a 20 minute discharge from sprinklers in a single bay.

5) The retention basin shall be protected from the environment. The basin shall include a sump to allow sampling and pumping of the retention basin water to a tanker truck.

f. Decontamination shower shall be self-contained and shall not drain to the retention basin. 
g. Piping from the VPS and TWS shall be routed to the PWC system. Piping shall be designed and constructed in accordance with ASME B31.3.

h. Water from the PWC system shall be routed to a storage tank.

\subsubsection{Compressed/Instrument Air.}

a. The instrument air system shall be used to operate air-operated control valves and to provide air for general use with air-operated tools. The air shall be provided by a compressor sized according to the following requirements.

1) The delivery rate shall be determined by assuming that all air operated process valves and air-driven HVAC dampers actuate simultaneously with the operation of a single air-driven tool.

2) The receiver tank shall be designed in accordance with the ASME Code, Section VIII, and sized to supply air to activate all valves and HVAC dampers twice.

3) The normal operating pressure is $690 \mathrm{kPa}\left(100 \mathrm{lb} / \mathrm{in}^{2}\right)$.

4) Instrument air shall be free from oil and shall be dried to $2^{\circ} \mathrm{C}\left(35^{\circ} \mathrm{F}\right)$ pressure dew point based on $690 \mathrm{kPa}(100 \mathrm{lb} / \mathrm{in} 2)$ and $38^{\circ} \mathrm{C}\left(100^{\circ} \mathrm{F}\right)$ ambient.

5) Piping shall be designed and constructed in accordance with ASME B31.9.

\subsubsection{Helium Supply System.}

a. The helium shall be distributed to the process bays for use as an MCO purge cover gas.

b. Helium shall be supplied from a tube trailer located outside the building where it can be accessed by delivery trucks.

c. The helium supply volume shall be sized to provide a minimum of 2 weeks peak process demand rate. The maximum expected delivery rate shall be $283 \mathrm{~L} / \mathrm{min}$ (10 standard $\left.\mathrm{f}^{3} / \mathrm{min}\right)$. The delivery pressure shall be regulated to $138 \mathrm{kPa}\left(20 \mathrm{lb} / \mathrm{in}^{2}\right)$.

d. Bottled gases and associated piping shall be in accordance with Compressed Gas Association guideline pamphlets and ASME B31.3.

6.6.4.9 Breathing Air System. No central breathing air system is required. Operators will wear self-contained breathing apparatus units if an event requiring supplied air entry should occur.

6.6.4.10 Reference Air System. Reference air shall be provided for the differential pressure and zone controls for a reliable reference to atmospheric pressure. The reference air point shall be 
located in a well-designed, shielded dampener such that rapid changes in wind speed or direction, or sudden atmospheric changes will not affect the reference air system.

\subsubsection{Safety Performance Requirements}

The safety classification and seismic performance category for piped systems SSCs are listed in Table 6-6.

Table 6-6. Structure, System, and Component Structural Performance Categories.

\begin{tabular}{|l|c|c|}
\hline \multicolumn{1}{|c|}{ SSC name } & $\begin{array}{c}\text { Safety } \\
\text { classification }\end{array}$ & $\begin{array}{c}\text { Anchorage } \\
\text { performance }\end{array}$ \\
\hline Service water, potable water, sanitary sewage & GS & PC-2 \\
\hline $\begin{array}{l}\text { Chilled/cooling water, deionized water, compressed/instrument air, } \\
\text { reference air }\end{array}$ & GS & PC-2* \\
\hline Helium & GS & PC-2* \\
\hline $\begin{array}{l}\text { Process bay floor drains, VPS, TWS interconnecting piping, Process bay } \\
\text { HVAC condensate drains }\end{array}$ & SS & PC-2* \\
\hline
\end{tabular}

*PC-3 anchorage is required where GS piping and equipment could impact SS and/or SC systems.

$\mathrm{GS}=$ general services.

HVAC $=$ heating, ventilating, and air conditioning.

PC. 2 = performance category 2

SS $=$ safety significant.

SSC = structure, system, and component.

TWS $=$ tempered water system.

VPS $=$ vacuum and purge system.

\subsubsection{Codes and Standards Documents}

The codes, standards, and source documents that apply to the CVDF piped systems are listed in Table 6-7.

\subsection{FIRE PROTECTION}

This section of the DRD addresses the fire protection requirements for the CVDF. The topics included are fire prevention, fire loss limitation, fire detection, fire suppression, and fire safety. 
Table 6-7. Codes, Standards, and Source Documents that Apply to Cold Vacuum Drying Facility Piped Systems.

\begin{tabular}{|c|c|c|c|}
\hline Category/application & General service SSCs & Safety-significant SSCs & Safety-class SSCs \\
\hline $\begin{array}{l}\text { Chilled/cooling water systems } \\
\text { piping, valves, and pumps }\end{array}$ & $\begin{array}{l}\text { ARI } \\
\text { ASME B31.9, B31.5 } \\
\text { ASME VIII } \\
\text { ASME B. } 16 . \mathrm{xx}\end{array}$ & Same as general service & ASME III* \\
\hline Deionized water piping and valves & $\begin{array}{l}\text { ASME B31.9 } \\
\text { ASME B16.xx }\end{array}$ & Same as general service & ASME III* \\
\hline $\begin{array}{l}\text { Potable water, filtered water, and } \\
\text { sanitary sewer piping and tanks }\end{array}$ & $\begin{array}{l}\text { UPC, UL } 1316 \\
\text { AWWA C652, SDC-3.2 } \\
\text { AWWA-NW Cross } \\
\text { Connection Control } \\
\text { Manual, Pacific Northwest } \\
\text { Committee, 6th Edition }\end{array}$ & Same as general service & ASME III* \\
\hline $\begin{array}{l}\text { Condensate, floor drain, PWC } \\
\text { interconnecting pipes and tanks }\end{array}$ & $\begin{array}{l}\text { ASME B31.1 } \\
\text { B31.3 } \\
\text { AWWAD } 100\end{array}$ & Same as general service & ASME III* \\
\hline Compressed air piping & $\begin{array}{l}\text { CGA } \\
\text { ASME B31.9 } \\
\text { ASME VIII } \\
\text { ASME B16.xx }\end{array}$ & Same as general service & ASME III* \\
\hline Helium piping & $\begin{array}{l}\text { CGA } \\
\text { ASME B31.3 } \\
\text { ASME VIII } \\
\text { ASME B16.xx }\end{array}$ & Same as general service & ASME III* \\
\hline Reference air & $\begin{array}{l}\text { ASME B31.9 } \\
\text { ASME VIII }\end{array}$ & Same as general service & ASME III* \\
\hline
\end{tabular}
designed.

*ASME Code, Section III, or comparable safety-related codes and standards that are appropriate for the system being

DOE $=$ U.S. Department of Energy.

$\mathrm{PWC}=$ process water conditioning.

$\mathrm{SSC}=$ structure, system, and component.

\subsubsection{Location, Boundaries and Interfaces}

6.7.1.1 Location and Boundaries. The fire protection system location and boundaries include the facility sprinkler system in all occupied areas, a standalone fire alarm system, and a fire riser loop around the outside of the CVDF. The CVDF shall incorporate non-combustible materials into the design as much as possible to reduce or eliminate the facility fire load.

6.7.1.2 Interfaces. The fire protection system interfaces inlcude a tie-in to the service water main in the $165 \mathrm{~K}$ cross-tie, the Hanford Site radio fire alarm repeater system to the Hanford 
200 Area, the facility HVAC system for fire dampers and HEPA filter protection, the facilities piped systems for floor drains and fire suppression distribution loops, and a UPS for the alarm system.

\subsubsection{Facility Functional Requirements}

a. Two independent sources of firewater are not required by DOE Order 5480.7A because the maximum possible fire loss estimate does not exceed $\$ 50$ million.

b. Process bays and mechanical rooms shall be designed for Ordinary Hazard, Group 2 occupancy.

c. Office and service areas shall be designed for Ordinary Hazard, Group 2 occupancy. Light Hazard occupancy classification is not permitted.

\subsubsection{Safety Functional Requirements}

There are no nuclear safety functional requirements for fire protection.

6.7.3.1 Fire Hazards Analysis. A preliminary fire hazards anaiysis, WHC-SD-SNF-FHA-003, has been published, and the following criteria are in accordance with and supported by the analysis. The design shall comply with the assumptions and conclusions of that document.

a. The fire protection design shall comply with the requirements of DOE Order 5480.7A, Fire Protection; NFPA 801, Facilities Handling Radioactive Materials; DOE Order 6430.1A, General Design Criteria, and HNF-PRO-340 through 373, "Project Hanford Policy and Procedure System."

b. There shall be inert gas purge, air ingress protection, and process recipe controls to manage the initiation of hydrogen deflagration and fuel ignition events in accordance with NFPA 69, Explosion Prevention Systems.

c. Design basis fires shall be SNF-hydrogen ignition, spilled fuel and truck fire, and an operation support area fire with loading as given in WHC-SD-SNF-FHA-003.

d. Two independent sources of water are not required by DOE $5480.7 \mathrm{~A}$ criteria because the maximum possible fire loss does not exceed $\$ 50$ million. Two sources are required by DOE Order $6430.1 \mathrm{~A}$ and RLID 5480.7 criteria. The present $100 \mathrm{~K}$ Area service water system cannot support two independent sources of water to the CVDF without extensive modifications. If this criterion is not met, an exemption/equivalency from the orders shall be obtained. 
6.7.3.2 Life Safety Code. The CVDF shall be divided into two fire zones by a 2 -hour fire-rated wall in accordance with the UBC. The support area is classified as business occupancy. The process bay area is classified as special purpose industrial occupancy. Each area shall comply with all requirement in its respective chapter in NFPA 101.

\subsubsection{Functional Performance Requirements}

\subsubsection{Firewater System.}

\subsection{Firewater Supply.}

a. The underground fire water distribution system shall be designed and installed in accordance with the requirements of NFPA 24 . The fire protection system supplied from this distribution system shall incorporate a post indicator valve.

b. Underground fire water mains, including valves, hydrants, and fittings, shall be installed, flushed, sterilized, and tested in accordance with the requirements of the NFPA.

c. Whenever feasible, all water distribution systems shall be of the looped-grid type providing two-way flow with sectional valving arranged to provide alternate water flow paths to any point in the system.

d. Fire mains shall be at least 8 in. Sprinkler supply lead-ins should be at least 6 in. In no case shall the lead-in be smaller than the sprinkler riser.

Distribution mains that supply water for domestic and/or process water and that will provide water for fire suppression shall be at least 12 in. in diameter.

e. Sprinkler risers shall be located at exterior walls.

f. Sprinkler supply lead-ins shall run under buildings the minimum distance possible.

g. Outside control valves shall be located, if possible, a minimum distance of $12.2 \mathrm{~m}$ $(40 \mathrm{ft})$ from the building.

h. All lead-ins shall be connected with the sprinkler system at the base of the riser.

i. Alarm valves shall be located as close as practical to the building entry point.

j. Hydrants shall be provided so that hose lays from hydrants to all exterior portions of a protected building are not more than $91.4 \mathrm{~m}(300 \mathrm{ft})$.

k. Hydrants shail not be closer to buildings than $15.2 \mathrm{~m}(50 \mathrm{ft})$. 


\subsection{Automatic Sprinkler System.}

a. Sprinkler systems shall be wet-pipe and installed in accordance with NFPA 13.

b. Hydraulic designs shall be required for all systems.

c. NFPA 13 shall be used to determine the hazard classification for any facility. The type and location of all sprinkler systems are shown on the fire protection drawings.

d. NFPA 13 shall be used to determine water supply requirements.

e. Density curves presented in NFPA 13 shall be used for calculating sprinkler demand for hydraulically designed systems.

f. Process bays and mechanical rooms shall be designed for Ordinary Hazard, Group 2 occupancy.

g. Office and service areas shall be designed for Ordinary Hazard, Group 2 occupancy. Light Hazard occupancy classification are not permitted.

h. Hose stream requirements shall be a minimum of $31.5 \mathrm{~L} / \mathrm{sec}(500 \mathrm{gal} / \mathrm{min}) \mathrm{regardless}$ of the hose stream demands listed in the above references. Determination of the adequacy of water supplies will be made on the basis of actual flow test measurements gathered using methods in NFPA 13, Appendix B.

\subsection{Firewater Collection.}

a. Floor drains are covered in Section 6.6.4.6 of this DRD.

\subsubsection{Fire Alarm and Detection Equipment.}

a. All fire detection and alarm devices shall be suitably listed by UL or approved by Factory Mutual.

b. Devices and systems shall comply with NFPA 72 as applicable (DOE Order 6430.1A, paragraph 1530-8.1).

c. All fire alarm and detection equipment shall be similar to and compatible with a "Pyrotronics System 3" or equal. A single system shall be selected for use throughout the site.

d. The fire alarm control panel shall have the ability to interface with the Hanford Site radio fire alarm reporter boxes. 
6.7.4.2.1 System Features. All fire alarm systems shall have the following basic features:

a. Transmission of signals to the 200 Area fire department alarm center

b. Local alarms for the building or zone in alarm

c. Transmission of trouble signals as required by NFPA 72

d. Appropriately sized, emergency 60-hour battery backup for system operation

e. Electronic supervision of all circuits as required by the appropriate NFPA standard

f. Supervisory devices for all critical functions (valve position switches, water level, temperature)

g. Capability of annunciating at least three separate conditions: (1) fire alarm, (2) a supervisory alarm, (3) a trouble signal indicating a fault in either of the first two conditions; annunciation of each condition will be separate and distinct from the other two

h. Bypass test switches for all smoke detectors that operate dampers, shut down HVAC equipment, or trip pre-action systems

i. A fire alarm control panel that has the ability to transmit subsequent soundings of fire alarm panel supervisory signals.

\subsection{Fire Alarm Equipment.}

a. The fire alarm equipment shall be suitably listed for the combination of detection, control, and actuating devices and installed per NFPA 72.

b. The fire alarm panel and associated equipment shall be a "Pyrotronics System 3" or equal.

c. All systems shall interface with the Site radio fire alarm reporter system that relays the alarm to the Hanford Site 200 Area fire station.

d. All fire alarm equipment shall be standardized for the site and compatible with the existing equipment.

e. Alarms that respond to the flow of water shall be provided wherever a sprinkler system is installed and shall comply with requirements of the NFPA standard for the type of signaling system used (6430.1A paragraph 1530-8.2.2). A manual fire notification method such as manual fire alarm boxes shall be provided and located in accordance with the appropriate NFPA standard. 


\subsection{Automatic Fire Detection System.}

a. Automatic fire detection systems shall be used to supplement or actuate extinguishing systems.

b. Automatic fire detectors shall comply with the requirements of NFPA 72. Detector spacing shall be in accordance with NFPA 72.

c. Smoke detectors shall be installed in all areas. Smoke detectors shall be photoelectric type as described in NFPA 72. Location and required spacing of smoke detectors shall be determined by the methods of NFPA 72. Spacing shall be based on threshold fire size, growth rate, and ceiling height as described in the standard.

\subsubsection{Fire Barriers.}

\subsection{Fire Walls.}

a. The operation support area shall be separated from the process area by a 2-hour firerated wall.

b. Walls separating the process bays shall be made from precast concrete panels, steel framing, and noncombustible materials in a fire-rated configuration.

6.7.4.3.2 Fire Proofing. The Fire Hazards Analysis (WHC-SD-SNF-FHA-003) has determined that structural steel fireproofing shall not be required.

\subsection{Fire Doors and Dampers.}

a. All closable openings in firewalls and ventilation systems penetrating rated fire separations shall be provided with fire doors or fire dampers of the appropriate ratings in accordance with NFPA 801.

b. Fire doors in 3-hour fire walls shall be class A, in 2-hour fire walls class B, and in 1-hour fire walls class $C$. Fire doors and other closable openings are not permitted in 4-hour fire rated walls. Three- and four-hour firewalls shall be provided only as required. Stairwells require 1-hour, class B fire doors. All fire doors shall be tested in accordance with the requirements of ASTM E-119 and be listed by UL or approved by Factory Mutual in accordance with NFPA 80.

6.7.4.3.4 Fire Rated Penetrations. Penetrations in fire-rated separations shall be sealed with fire-rated materials that have been tested in accordance with the requirements of ASTM E-119 and listed by UL or approved by Factory Mutual. All sealing materials shall be suitable for the fire rating of the wall, floor, or ceiling and listed for use with the applicable building materials and the penetration configuration. 
HNF-SD-SNF-DRD-002 REV 1

\subsubsection{Safety Functional Requirements}

The safety functional requirements are covered in the functional performance requirements in this section of the DRD.

\subsubsection{Codes, Standards, and Source Documents}

The codes and standards that will govern the fire protection and detection design of this project are shown in Table 6-8.

Table 6-8. Codes, Standards, and Source Documents Applicable to the Design of Fire Protection Systems in the Cold Vacuum Drying Facility.

\begin{tabular}{|l|l|l|l|}
\hline \multicolumn{1}{|c|}{ Category/application } & \multicolumn{1}{|c|}{ General service SSCs } & \multicolumn{1}{c|}{ Safety-significant SSCs } & \multicolumn{1}{c|}{ Safety-class SSCs } \\
\hline Fire alarms & NFPA 72 & Same as GS & Same as GS \\
\hline Fire protection piping and testing & NFPA 13,15,24,25 & Same as GS & Same as GS \\
\hline Electrical & NFPA 70 (NEC) & Same as GS & Same as GS \\
\hline Water piping and valves & $\begin{array}{l}\text { ASME B31.9 } \\
\text { ASME B16 series }\end{array}$ & Same as GS & ASME III* \\
\hline General fire protection design & $\begin{array}{l}\text { NFPA 101 } \\
\text { Factory Mutual } \\
\text { NFPA 80A } \\
\text { ASTM E1 19 }\end{array}$ & Same as GS & Same as GS \\
\hline
\end{tabular}

*ASME Code, Section III, or comparable safety-related codes and standards that are appropriate for the system being designed.

$\mathrm{GS}=$ general services

$\mathrm{SSC}=$ structure, system, and component.

\subsection{RADIOACTIVE EFFLUENT HANDLING AND DISPOSAL}

\subsubsection{Locations, Boundaries, and Interfaces}

TBD.

\subsubsection{Facility Functional Requirements}

TBD. 
HNF-SD-SNF-DRD-002 REV 1

\subsubsection{Safety Functional Requirements}

TBD.

\subsubsection{Functional Performance Requirements}

Handling and disposal design shall be such that the effluents meet the low specific activity material requirements, which means any of the following shall be the end product:

- Uranium or thorium ores and physical or chemical concentrates of those ores

- Unirradiated natural or depleted uranium or unirradiated natural thorium

- Tritium oxide in aqueous solutions provided the concentration does not exceed $5.0 \mathrm{mCi} / \mathrm{mL}$.

- Material in which the radioactivity is essentially uniformly distributed and in which the estimated average concentration per gram of contents does not exceed

- $\quad 0.0001 \mathrm{mCi}$ of radionuclides for which the A2 quantity in Appendix A of $10 \mathrm{CFR} 71$ is not more than $0.05 \mathrm{Ci}$

-. $\quad 0.005 \mathrm{mCi}$ of radionuclides for which the A2 quantity in Appendix A of $10 \mathrm{CFR} 71$ is more than $0.05 \mathrm{Ci}$ but not more than $1 \mathrm{Ci}$

- $\quad 0.3 \mathrm{mCi}$ of radionuclides for which the A2 quantity in Appendix A of 10 CFR 71 is more than $1 \mathrm{Ci}$

- Objects of nonradioactive material externally contaminated with radioactive material provided that the radioactive material is not readily dispersible and the surface contamination when averaged over an area of $1 \mathrm{~m}^{2}$ does not exceed $0.0001 \mathrm{mCi}$ (220,000 disintegrations per minute) per square centimeter of radionuclides for which the A2 quantity in Appendix A of 10 CFR 71 is not more than $0.05 \mathrm{Ci}$ or $0.001 \mathrm{mCi}$ $(2,200,000$ disintegrations per minute) per square centimeter for other radionuclides.

\subsubsection{Safety Performance Requirements}

TBD.

\subsubsection{Codes and Standards}

The low specific activity definition from 10 CFR 71, Subpart 71.4 is found in Appendix C. 
HNF-SD-SNF-DRD-002 REV 1

\subsection{SPECIALTY EQUIPMENT AND TOOLS REQUIREMENTS}

\subsubsection{Locations, Boundaries, and Interfaces}

Several items of specialty equipment and tools are required to operate the CVDF. The following is a list of known specialty equipment and tools that are required to operate the process. This list is not intended to be all-inclusive, nor does it identify necessary components for maintenance of the process skids or facility. Any special tools required for the maintenance of the equipment and skids shall be included with the equipment.

\subsubsection{Facility Functional Requirements}

\subsubsection{Specialty Equipment.}

a. PWC Transporter and Water Tank. A truck and tanker shall be used to transport conditioned water from CVDF to the K Basins IWTS for disposat. The truck and tanker will be a part of the IWTS project.

b. PWC Sample Bottle Cask. A shielded cask is required to store and transport samples from the PWC system.

c. Vacuum Pumping System Test Vacuum Vessel. A test vessel is required for each bay to test the VPS.

d. Swipe Count Pigs. Swipe count pigs will be required in each process bay.

\subsubsection{Special Tools.}

a. Cask Lid Lift Fixture. A lifting sling shall be provided for each bay to remove the cask lid before to the installation of the process hood and seal ring.

b. Cask Lid Bolting Torque Wrench and Sockets. A torque wrench with extension and sockets for the cask lid bolts shall be provided for each bay. Various socket sizes, wrenches, and pneumatic tools shall be available for use in each bay.

c. MCO Process Port Cover Removal and Installation Tool. A tool is required for each bay to remove and install the MCO process port covers.

d. MCO Process Port Connector Installation Tool. A tool is required for each bay to remove and install the $\mathrm{MCO}$ process port connector. 
e. Process Hood Lift Fixture. A sling is required in each bay to install and remove the process hood-seal ring to the cask. A sling shall be designed to allow the installation and removal of the process hood from the cask.

f. Cask Drain Port Tools. Tools are required for each bay to remove and install the cask drain port cover and to install the tempered water lower cask port connection.

g. Cask Vent Port Actuation Tool. A tool is required for each bay to actuate the cask vent port and purge the casks' gaseous contents to the CVDF vent system.

h. Cask Truck Exhaust Elephant Trunk. A system shall be designed for each bay to prevent the exhaust fumes from the cask truck from entering the process bay during delivery or removal of the cask transport trailer.

i. PWC Tank Room Hatch Lifting Fixture. A lifting fixture shall be included for the PWC tank room hatch.

j. PWC IXM Lifting Fixture. A lifting fixture shall be included for the removal and installation of the IXMs.

k. PWC and Vacuum Pumping System Process Skid Tools. Tools, other than standard, required for the maintenance of the PWC system and VPS and TWS shall be included with the equipment.

1. HEPAFilter Changeout Tools. Tools, other than standard, required for the removal of the HEPA filters from the filter housings shall be included with the equipment.

m. Instrumentation and Controls Calibration Tools. Calibration tools are required to verify and recalibrate instrumentation.

n. Floor Drain Radiation Monitor. A device is required to monitor the process bay floor drains for radiation.

o. Helium Leak Checker. A helium detector is required to verify leaktightness of the process systems.

p. Cask Transporter Air Supply Glad Hand. A pneumatic hose with quick-connect on one end and glad hand and control valve compatible with the cask transport trailer shall be provided in each bay. The hose shall be connected to the building's compressed air system. 


\subsubsection{Safety Functional Requirements}

All specialty equipment and special tools shall be designed to minimize exposures to radiation and chemicals. ALARA principles shall be used in the design and functions of the specialty equipment and special tools.

Cask transporter seismic restraints, if required, shall be included in each bay. The restraints shall restrain the cask and cask transporter during a DBE.

\subsubsection{Functional Performance Requirements}

\subsubsection{Specialty Equipment.}

a. PWC Transporter and Water Tank. A truck and tanker trailer will be provided by another project.

b. PWC Sample Bottle Cask. A shielded cask is required to store and transport samples from the PWC system.

c. Vacuum Pumping System Test Vacuum Vessel. A known volume tank capable of operating from $13 \mathrm{~Pa}$ ( 0.1 torr) to $101 \mathrm{kPa}(1 \mathrm{~atm})$ shall be provided for testing of the vacuum process system skid.

d. Swipe Count Pigs. Swipe count pigs will be required in each process bay.

\subsubsection{Special Tools.}

a. Cask Lid Lift Fixture. A lifting sling shall be provided for each bay to remove the cask lid before to the installation of the process hood and seal ring. Slings shall meet the requirements of DOE-RL-92-36, Hanford Site Hoisting and Rigging Manual.

b. Cask Lid Bolting Torque Wrench and Sockets. A torque wrench with extension and socket for the cask lid bolts, capable of a minimum of $407 \mathrm{~N} \cdot \mathrm{m}(300 \mathrm{ft} \cdot 1 \mathrm{~b})$, shall be provided for each bay. Spare wrenches shall be included to allow continued operations when recalibration is required. Various socket sizes, wrenches, and pneumatic tools shall be available for use in each bay.

c. MCO Process Port Cover Removal and Installation Tool. A tool is required for each bay to remove and install the MCO process port covers.

d. MCO Process Port Connector Installation Tool. A tool is required for each bay to remove and install the $\mathrm{MCO}$ process port connector. 
e. Process Hood Lift Fixture. A sling is required in each bay to install and remove the process hood-seal ring to the cask. A sling shall be designed to allow the installation and removal of the process hood from the cask. Slings shall meet the requirements of the Hanford Site Hoisting and Rigging Manual (DOE-RL-92-36).

f. Cask Drain Port Cover Tool. A tool is required for each bay to remove and install the cask drain port cover.

g. Cask Vent Port Actuation Tool. A tool is required for each bay to actuate the cask vent port.

h. Cask Truck Exhaust Elephant Trunk. A system shall be designed for each bay to prevent the exhaust fumes from the cask truck from entering the process bay during delivery or removal of the cask transport trailer. The cask truck may have up to two exhausts outlets.

i. PWC Tank Room Hatch Lifting Fixture. A lifting fixture shall be included for the PWC tank room hatch. Lifting fixtures shall meet the requirements of the Hanford Site Hoising and Rigging Manual (DOE-RL-92-36).

j. PWC IXM Lifting Fixture. A lifting fixture shall be included for the removal and installation of the IXMs. Fixtures shall meet the requirements of the Hanford Site Hoisting and Rigging Manual (DOE-RL-92-36).

k. PWC and Vacuum Pumping System Process Skid Tools. Tools, other than standard, required for the maintenance of the PWC system and VPS and TWS shall be included with the equipment.

1. HEPAFilter Changeout Tools. Tools, other than standard, required for the removal of the HEPA filters from the filter housings shall be included with the equipment.

m. Instrumentation and Controls Calibration Tools. Calibration tools are required to verify and recalibrate instrumentation.

n. Floor Drain Radiation Monitor. A device is required to monitor the process bay floor drains for radiation.

o. Helium Leak Checker. A helium detector is required to verify leaktightness of the process systems.

p. Cask Transporter Air Supply Glad Hand. A pneumatic hose with quick-connect on one end and glad hand and control valve compatible with the cask transport trailer shall be provided in each bay. The hose shall be connected to the building's compressed air system. 


\section{HNF-SD-SNF-DRD-002 REV 1}

\subsubsection{Safety Performance Requirements}

The cask transporter seismic restraints shall be designed to PC-3 requirements. All other tools are general service pieces of equipment.

Cask transporter seismic restraints, if required, shall be included in each bay. The restraints shall restrain the cask and cask transporter to PC-3 design loads, the cask and cask transporter. weigh approximately $47,000 \mathrm{~kg}(105,000 \mathrm{lb})$.

\subsection{SECURITY SYSTEM REQUTREMENTS}

This section addresses physical security design requirements for the CVDF. These requirements are based on a combination of DOE directives, the September 1996 VuInerability/Risk Analysis, protective force requirements, material and accountability requirements, operational security procedures, and administrative controls.

\subsubsection{Location, Boundaries and Interfaces}

The CVDF security system serves the facility functions and as such is discussed in detail below as a facility system.

6.10.1.1 Location. The security system operation's work stations shall be located in a designated CVDF security room. All remote input/output (I/O) locations shall be located in accessible locations near the security area they monitor; all sensor input shall be routed to the security system equipment in the designated security room.

6.10.1.2 Boundaries. The boundary of the security system includes all components starting at the sensors and equipment and ending at the wiring terminations at the security monitoring equipment. The security system encompasses all of the facility structures of the CVDF and extends out to the security fence bordering the CVDF.

6.10.1.3 Interfaces. The security system is the primary access and security monitoring system for the CVDF, interfaces with all facility structures, and requires electrical power for operation. A security system UPS shall be provided in the event of loss of facility electrical power.

\subsubsection{System Functional Requirements}

\subsubsection{Security Designations and Criteria.}

a. All of the process bays will be considered a limited area when a loaded cask-MCO is present and will be subject to limited area requirements (minimum " $2 / \mathrm{L}$ " security clearance for unescorted access). 
b. All areas surrounding the facility as well as the administrative areas outside the process bays, corridor, and control room will be considered a property protection area.

c. All open pipeline conduit runs or penetrations from the limited area will terminate within the limited area or be welded shut.

d. All locks, locking hardware, and finish hardware will meet the B\&W Protec, Inc. Standard Specification for furnishing and installing all items of finish hardware necessary for completion of the project (BWP Standard Specification for Locks, Locking Hardware, and Finish Hardware, dated January 25, 1994).

e. All limited area doors will be equipped with panic hardware for emergency egress. For security purposes, paddle/button type hardware will be required for all limited area doors.

f. B\&W Protec, Inc., Security Engineering will provide design and installation oversight during the design and construction phases to include precise location of security sensors and cameras.

g. The CVDF security system will be subject to acceptance and performance testing by B\&W Protec, Inc., and RL Safeguards and Security before acceptance of the system from the contractor.

6.10.2.2 Delay. The design shall incorporate compensatory measures (e.g., 16-mm [5/8-in.] rebar on 152-mm [6-in.] centers) to limit access to unattended openings within the process bay, wall, or ceiling that are

a. Greater than $619 \mathrm{~cm}^{2}\left(96 \mathrm{in}^{2}\right)$ in area and greater than $39 \mathrm{~cm}^{2}\left(6 \mathrm{in}^{2}\right)$ in the smallest dimension

b. Located within $5.5 \mathrm{~m}(18 \mathrm{ft})$ of the ground, roof, or ledge of a property protection area

c. Located within $4.3 \mathrm{~m}$ (14 ft) diagonally or directly opposite windows, fire escapes, roof escapes, roofs, or other openings in uncontrolled adjacent buildings

d. Located $1.8 \mathrm{~m}(6 \mathrm{ft})$ from uncontrolled openings in the same barrier.

\subsubsection{Access Control.}

a. Access will be controlled by an automated access control system with a proximity card reader used at the following locations:

- CVDF main entry exterior door

- Control room door 
- Process bay access corridor entry door

- Security equipment room door

- Limited area (process bay) entry doors.

b. Request-to-exit buttons will be used on the bay side of limited area doors.

c. CVDF security area status indicator will be located at the following locations:

- On the bay side of limited area entry doors

- Inside the operations control room.

d. Initial access to the limited area will require two authorized personnel with a minimum " $2 / L$ " security clearance. After the central alarm station has acknowledged access to the limited area the green light indicator will appear. Limited area entrance doors will remain locked. Follow-on entry will be allowed by one or more individuals based on proximity card authorization.

e. B\&W Protec, Inc., and DE\&S Hanford Operations will define access sets.

\subsubsection{Administrative and Procedural Controls.}

a. Personnel entering any limited area (process bays) will have a minimum " $2 / \mathrm{L}$ " security clearance or be escorted.

b. Truck drivers transporting a loaded $\mathrm{MCO}$ will have a minimum " $2 / \mathrm{L}$ " security clearance.

c. The two-person rule applies for placing sensors in the access mode. However, one of these individuals may use remote observations or locations for performing certain operations. This will be reflected within the CVDF administrative procedures. An empty process bay will be exempt from the two-person rule.

d. The limited areas will be kept free of nonessential equipment or supplies. Essential materials will be positioned in such a manner as to not hinder the operation or effectiveness of sensors and cameras.

e. "Limited Area" and "Prohibited Article" signs, in accordance with DOE M 5632.1C-1, Manual for Protection and Control of Safeguards and Security Interests, will be posted on or near the following doors:

- Limited area exterior pedestrian door

- Limited area shipping door. 


\subsubsection{Material Control and Accountability.}

a. The CVDF will be a new Category IDD material balance area.

b. All book values for scrap will be adjusted at the $\mathrm{K}$ Basins. Then the MCO will be the item accounted for in accordance with the order. Book values will follow the item.

\subsubsection{Hanford Patrol.}

a. Based upon implementation of this security concept, the CVDF will be able to operate without permanently assigned protective forces.

b. The area within $30 \mathrm{~m}(100 \mathrm{ft})$ of the CVDF will be kept free and clear of nonessential equipment and obstructions.

\subsubsection{Safety Functional Requirements}

There are no safety functions performed by the security system.

\subsubsection{Functional Performance Requirements}

\subsubsection{Security Sensors.}

a. The limited area (process bay) will contain intrusion detection sensors (one level of alarm with DOE-approved, dual-technology sensors). Sensors will provide complete coverage of the bay floor, process skid operations area, and all doorways, including the shipping doors of the designated limited area.

b. The following access doors to the limited area will be equipped with balanced magnetic switches:

- Exterior pedestrian doors

- Shipping doors.

c. A shielded duress button will be installed in or near the following locations:

- Operations control room on operators work station

- Process bay access corridor wall outside near the main entry/exit door

- In each process bay near the corridor access doors and on the south wall of each bay, approximately in the middle of the bay at the cask access platform

- On the north wall of the access corridor. 
d. The duress annunciation points are as follows:

- Central Alarm Station - 200 West Area, visual and audible

- Each bay, the corridor, and the control room, with separate sensor identification numbers (seven unique identifiers)

- CVDF control room, visual only.

There shall be a visual duress indication for each bay and the corridor (six separate indicators) displayed in the control room. Control room duress shall annunciate only at the 200 West Area central alarm station.

e. All security cabinets (alarm contact accumulation points, UPS, video equipment) will be provided with tamper switches on both front and back side and lockable cabinet doors. Junction boxes will be tamper protected.

f. Industrial alarms (e.g., fire, radiation, and criticality alarms will not interface to the security system or annunciate at the 200 West Area central alarm station).

\subsubsection{Surveillance and Assessment.}

a. Black-and-white closed circuit television security cameras will provide primary assessment for the limited areas. All interior video equipment will provide real-time video signal transmission capabilities ( 30 frames per second) and comply with the 75-ohm, RS-170 video standard.

b. Cameras will be in a fixed position to provide alarm assessment coverage of each process bay. Appropriate or selected cameras will be automatically displayed at the central alarm station upon any alarm activation.

c. Limited area video monitoring will be located at the following locations:

- CVDF control room, two 430-mm (17-in.) monitors

- Security equipment room, two 230-mm (9-in.), high-resolution, rack-mounted monitors.

\subsubsection{Security Transmission Lines.}

a. All CVDF security alarm data and signals from the cameras and sensors will be multiplexed and transmitted from the CVDF to the 200 West Area, Building 234-5Z, room 267 , via six dedicated, single-mode, fiber optic lines to comply with class B line supervision requirements. 
b. All security sensors, cameras, sensor and video transmission equipment, and partial interior building lighting shall be provided with an UPS system with a minimum of 8 hours run time at full load.

c. Each sensor alarm circuit and its associated tamper will be individually terminated at the CVDF's central security alarm system acquisition point located in the security equipment room. Conduits may contain multiple alarm circuit paths.

d. An auto-dial phone line with termination at 200 West Area, Building 234-5Z, room 267 will be provided in the following locations:

- Security room

- All process bays

- All change rooms (process bay entry rooms).

e. Security sensors, video, and other associated security transmission lines internal to the CVDF will be installed in electrical metallic tubing-type conduit and/or liquid-tight flex conduit. Rigid conduit will be used where security system conduit is located below the height of $2.1 \mathrm{~m}(7 \mathrm{ft})$ to preclude possible mechanical damage. All condulet covers will be secured with tamper-resistant bolts or screws.

f. All security system junction boxes will be NEMA Type 3 or better with a minimum 6-mm (1/4-in.) recessed or lipped cover edge and no unused knockouts.

g. No wiring splices or junctions will be allowed between the security sensors and the security system acquisition point unless they occur within an approved tamper switch-equipped junction box.

h. Security system and communication transmission lines, to include the ring-down phones inside the property protective area, will be dedicated to the security system.

\subsubsection{Lighting.}

a. The limited area will be illuminated at all times with lighting of a minimum 2.2 lux ( 0.2 foot candles) at all floor level locations.

b. Lighting will be on a separate UPS from the security system.

c. External lighting will meet DOE Order 6430.1A.

\subsubsection{Building and Perimeter.}

a. The existing fencing around the CVDF will be retained and maintained as a compound boundary. 
b. The area within $30 \mathrm{~m}(100 \mathrm{ft})$ of the CVDF will be kept free and clear of nonessential equipment and obstructions.

\subsubsection{Safety Performance Requirements}

The safety, performance, and environmental requirements listed in Table 6-9 shall be met.

Table 6-9. Cold Vacuum Drying Facility Security System Design Requirements.

\begin{tabular}{|c|c|c|c|}
\hline Components & $\begin{array}{c}\text { Safety } \\
\text { classification }\end{array}$ & $\begin{array}{c}\text { NPH } \\
\text { performance } \\
\text { category }^{1}\end{array}$ & $\begin{array}{c}\text { Environmental } \\
\text { qualification } \\
\text { (see Table 5-3) }\end{array}$ \\
\hline Security system (all items) & General services & $\mathrm{PC}-2$ & 1 \\
\hline
\end{tabular}

$\mathrm{NPH}=$ natural phenomena hazards.

PC-2 = performance category 2.

\subsubsection{Codes, Standards, and Source Documents}

Codes, standards, and source documents that apply to design of the security system at the CVDF are listed in Table 6-10.

Table 6-10. Codes, Standards, and Source Documents Applicable to the Design of the Cold Vacuum Drying Facility Security System.

\begin{tabular}{|c|c|c|}
\hline Document title & Symbol/number & Area of coverage \\
\hline $\begin{array}{l}\text { Contractor Safeguards and Security } \\
\text { Program Requirements }\end{array}$ & DOE O 470.1 & TBD \\
\hline $\begin{array}{l}\text { Manual for Protection and Control of } \\
\text { Safeguards and Security Interests }\end{array}$ & DOE M 5632.1C-1 & TBD \\
\hline $\begin{array}{l}\text { Control and Accountability of Nuclear } \\
\text { Materials }\end{array}$ & DOE $5633.3 B$ & $\mathrm{TBD}$ \\
\hline General Design Criteria & DOE Order $6430.1 \mathrm{~A}$ & TBD \\
\hline $\begin{array}{l}\text { Protection of Safeguards and Security } \\
\text { Interests }\end{array}$ & RLID 473.1 & TBD \\
\hline Security Manual & WHC-CM-4-33 & TRD \\
\hline $\begin{array}{l}\text { BWP Standard Specification for Locks, } \\
\text { Locking Hardware, and Finish Hardware }\end{array}$ & January 25, 1994 & TBD \\
\hline
\end{tabular}

$\mathrm{BWP}=\mathrm{B} \& \mathrm{~W}$ Protec, Incorporated.

$\mathrm{TBD}=$ to be determined. 


\subsection{COMMUNICATIONS SYSTEM REQUIREMENTS}

\subsubsection{Location, Boundaries and Interfaces}

The CVDF communications system serves the facility operations function and as such is discussed in detail below as a facility system.

6.11.1.1 Locations. The communications system operations work center shall be located in the CVDF operations control room. All areas of the CVDF, internal and external, shall have access to the communications system.

6.11.1.2 Boundaries: The boundary of the communications system includes all communications equipment. The system encompasses all of the facility structures of the CVDF and interfaces with the $100 \mathrm{~K}$ Area communications, Hanford Local Area Network system, and the local telephone network.

6.11.1.3 Interfaces. The communications system provides the operations personnel the ability to communicate within the facility for the efficient operation of the facility systems. The communication system shall interface with the $100 \mathrm{~K}$ Area communications, the Hanford Local Area Network system, and the local telephone network. The CVDF communications system requires electrical power for operation. A system UPS shall be provided in the event of loss of facility electrical power.

\subsubsection{System Functional Requirements}

The communications system shall be designed to send and receive routine CVDF operations messages between the CVDF administrative locations and the respective process and utility areas of the CVDF. In addition, the system shall be capable of delivering emergency warning signals and messages to all personnel within the $100 \mathrm{~K}$ Area.

6.11.2.1 Intercom System. No intercom system will be required. Regular telephone service will be used. The system shall be capable of paging from every station.

6.11.2.2 Voice Paging System. The system should include the following features.

a. The voice paging system shall be controlled from the operations control room. The system shall be capable of paging from the control room into the CVDF work locations. These areas include the process bays, process water tank room, transfer corridor, mechanical equipment room, administrative annex and the external equipment pads.

b. The voice paging system shall be one-way. Talk-back speakers shall not be provided except in the process bays. 
c. The voice paging system shall be able to send alarm initiation codes and public address messages to multiple remote alarm stations. Codes for evacuation and take-cover signals shall be included in the voice paging system code list. The voice paging system shall include a voice hand set or provisions for a microphone to be used for the public address function.

d. The voice paging system shall be able to receive and translate alarm initiation codes from the $100 \mathrm{~K}$ Area alarm station. The voice paging system shall recognize the codes for evacuation and take cover alarms and shall be capable of broadcasting the standard Hanford Site signals for these alarms over the speaker and/or horns.

e. The link between the $100 \mathrm{~K}$ Area emergency warning signal base station and the remote alarm station at the CVDF shall be a radio base station. This radio shall carry modulated codes to differentiate among the different emergency signals that must be generated. Additionally, to send emergency messages, the radio shall be able to transmit voice signals for the speaker and/or horns at the remote alarm station at the CVDF.

f. The facility shall be connected to the existing 100-K Valcom voice paging system.

6.11.2.3 Telephones. The telephone system should include the following features

a. The telephone system shall provide standard telephone service throughout the facility.

b. The intercom and voice paging systems shall be integrated with the standard telephone system.

c. In addition to standard telephone service, a crash alarm phone will be provided for the facility. A crash alarm phone system shall be available to operations personnel to use in relaying emergency messages.

6.11.2.4 Hanford Local Area Network. Hanford Local Area Network service shall be extended to the CVDF to support routine operations administrative activities.

\subsubsection{Safety Functional Requirements}

There are no safety functions performed by the communications system.

\subsubsection{Communications Performance Requirements}

6.11.4.1 Voice Paging System. The voice paging system should include the following features. 
a. Speaker horns and ceiling-mounted speakers shall be located throughout the facility for the voice paging system.

b. Anti-blast control units shall provide automatic volume level adjustments in areas where ambient noise levels are continuously changing.

c. Voice paging equipment and raceways shall not be located within $0.5 \mathrm{~m}$ (18 in.) of a power supply, electrical panel, motor, or other equipment that generates electrical noises.

d. The voice paging system shall be one-way. Talk-back speakers shall not be provided, except in the process bays.

e. The sound level produced by the speaker and/or horns shall be $10 \mathrm{~dB}$ above background noise in all CVDF areas covered by the system. In areas where intermittent high-noise conditions exist or normal background noise exposure requires workers to wear ear protection, flashing lights of a distinctive color shall be triggered with any alarm signal or with any public address message. Provisions to reduce background noise interference shall be made at intercom stations in high-noise areas. Exterior alarm stations having pole, tower, or building-mounted speaker and/or horn clusters shall be designed to withstand a wind of $31 \mathrm{~m} / \mathrm{sec}(70 \mathrm{mi} / \mathrm{h})$. Exterior alarm stations shall have battery backup available to drive the speaker and/or horns for 30 minutes after a power outage.

6.11.4.2 Telephones. The telephones should include the following features.

a. Each telephone outlet shall include a telephone jack and data communications jack.

b. Cable shall be category 5, four twisted pairs per cable, 24 AWG solid copper conductors, grey in color for telephone and white in color for data communications.

c. A fax machine shall be located in the CVDF conference room.

6.11.4.3 Hanford Local Area Network. The Hanford Local Area Network system should include the following features.

a. Hanford Local Area Network service shall be provided to the shift operations manager's office, the process engineer/quality assurance office, the health physics technician's office, the operations control room, and the conference room.

\subsubsection{Safety Performance Requirements}

The safety, performance, and environmental requirements listed in Table 6-11 shall be met. 
HNF-SD-SNF-DRD-002 REV 1

Table 6-11. Cold Vacuum Drying Facility Communication System Design Requirements.

\begin{tabular}{|l|c|c|c|}
\hline \multicolumn{1}{|c|}{ Components } & $\begin{array}{c}\text { Safety } \\
\text { classification }\end{array}$ & $\begin{array}{c}\mathrm{NPH} \\
\text { performance } \\
\text { category }^{1}\end{array}$ & $\begin{array}{c}\text { Environmental } \\
\text { qualification } \\
\text { (see Table 5-3) }\end{array}$ \\
\hline $\begin{array}{l}\text { Communications system (all } \\
\text { items) }\end{array}$ & General services & PC-2 & 1 \\
\hline
\end{tabular}

$\mathrm{NPH}=$ natural phenomena hazard.

PC-2 = performance category 2 .

\subsubsection{Codes, Standards, and Source Documents}

The codes, standards, and source documents associated with the requirements for the design of the CVDF communications system are listed in Table 6-12.

Table 6-12. Codes, Standards, and Source Documents Applicable to the Design of the Cold Vacuum Drying Facility Communications System.

\begin{tabular}{|c|c|c|}
\hline Document title & Source/number & Area of coverage \\
\hline $\begin{array}{l}\text { Conduct of Operations, Requirements } \\
\text { for DOE Facilities }\end{array}$ & $\begin{array}{l}\text { DOE Order } 5480.19 \text {, Paragraph } 5 \text { of } \\
\text { Conduct of Operations }\end{array}$ & Requirements for routine operations \\
\hline Emergency Management System & $\begin{array}{l}\text { DOE Order } 5500.18 \text {, Sections } 9 \text { and } \\
10\end{array}$ & $\begin{array}{l}\text { DOE requirements for facility } \\
\text { operational emergency preparedness }\end{array}$ \\
\hline $\begin{array}{l}\text { Planning and Preparing for } \\
\text { Operational Emergencies }\end{array}$ & DOE Order 5500.3A, Section 11 & $\begin{array}{l}\text { DOE requirements for facility } \\
\text { operational emergency preparedness }\end{array}$ \\
\hline $\begin{array}{l}\text { Hanford Emergency Response Plan } \\
\text {. }\end{array}$ & $\begin{array}{l}\text { DOE/RL-94-02, Sections } 6.2 \text { and } \\
6.2 .10\end{array}$ & $\begin{array}{l}\text { The requirement for emergency } \\
\text { communications }\end{array}$ \\
\hline $\begin{array}{l}\text { Standard Specification For } \\
\text { Emergency Audible Alarm Signals }\end{array}$ & KH-SD-GN-DGS-30013 & $\begin{array}{l}\text { Requirements to send and receive end } \\
\text { components of the emergency } \\
\text { warning signal }\end{array}$ \\
\hline Structural Design Loads & GC-Load-01, Section C.1 & $\begin{array}{l}\text { Tower and pole wind load } \\
\text { requirement }\end{array}$ \\
\hline
\end{tabular}

DOE $=$ U.S. Department of Energy. 


\subsection{RADIATION MONITORING SYSTEM}

\subsubsection{Location, Boundaries and Interfaces}

6.12.1.1 System Location. The system shall primarily monitor the process area and exhaust stack with instrumentation alarming locally and back to the MCS alerting the facility personnel. Instrument location shall be determined by documented failure-mode, effects, and criticality analysis and facility smoke tests as required.

6.12.1.2 System Boundaries. The system boundaries are the monitoring of the process area for radionuclides with area radiation monitors, continuous air monitors, and record samplers. Personnel monitoring is provided by personnel contamination monitors, local survey monitors, and room air quality monitors. The prevention of accidental contamination release is monitored through a stack monitoring system.

6.12.1.3 System Interfaces. The radiation monitoring system will interface with the electrical system providing uninterruptible power to the equipment and inputs to the MCS system for alarm and annunciation and HVAC for the stack monitoring. Mounted equipment and permanent components of the radiation monitoring system shall conform to the equivalent structural requirements of the UBC for zone $2 B$.

\subsubsection{Facility Functional Requirements}

a. The radiation monitoring system shall provide radiological monitoring of radiation exposure levels, radioactive contamination, and airborne radioactivity in order to characterize workplace conditions, to verify effectiveness of physical design features and engineering and administrative controls, and to identify areas requiring postings.

b. Area radiation monitoring shall follow the requirements of $10 \mathrm{CFR} 835$, Section 835; DOE Order 6430.1A, Section 1300-6.5.4; ANSI/ANS-HPSSC 6.8.1; ANSI N13.6-1972; and HSRCM-1, Chapter 5, Section 553, "Area Radiation Monitors."

Continuous air monitors shall follow the requirements of 10 CFR 835 , Section 835.403, and HSRCM-1, Chapter 5, Section 555, "Airborne Radiation Monitoring."

c. The continuous air monitors shall have sufficient setpoint adjustability, sensitivity, and audible and visual alarms to alert personnel that immediate action is necessary to minimize or terminate inhalation exposures per ANSI N42.17B-1989 and HSRCM-1 Article 555.6. 
Instrument response and electrical power requirements are operating are required per ANSI N42.17B.

d. Fixed-head filter record samplers shall be required for determining air radioactivity levels over a specific time period.

e. In accordance with HSRCM-1, Article 221, and 10 CFR 835, Article 404, personnel and personal property contamination monitoring shall be provided, as appropriate, and used immediately before or after exits from radiological buffer areas, surface contamination areas, and airborne contamination areas.

f. Shrouded probes shall be used for stack sampling with requirements per U.S. Environmental Protection Agency letter to DOE dated November 12, 1994.

g. The process bay air shall conform to Compressed Gas Association room atmosphere monitoring.

\subsubsection{Safety Functional Requirements}

The safety classification of the radiation monitoring system shall be general service.

\subsubsection{Functional Performance Requirements}

\subsubsection{Area Radiation Monitoring System.}

a. Area radiation monitors shall be provided to monitor radiation levels within and exterior to process bays within routinely occupied or restricted access areas (zone II contamination control areas). Remote or non-routinely occupied areas need monitoring control verification prior to entry.

b. The area radiation detector type shall be rated for medium- to high-energy gamma fields, Each detector shall provide audible and visible high radiation alarm indication locally, remotely at the MCS, and outside the entrances to the zone II rooms. The health physics office shall have alarm annunciator and silence only. Meter readings shall be at the detection point and at a remote location.

c. Detector range shall be determined at any expected peak exposure rate in accordance with ANSI/ANS-HPSSC, Section 4.3.3. Calculations shall be provided as part of the design packages.

d. Alarm beacons shall be visible form any point within $45^{\circ}$ from the horizontal in which they are mounted for $360^{\circ}$ around the beacon. The alarm beacons shall be capable of 
operating on $120 \mathrm{~V}$ ac electrical power for at least 1 hour of continuous use in accordance with ANSI/ANS-HPSSC, Section 5.5.1.

e. As required by ANSI/ANS-HPSSC, Section 5.5.4, the area radiation monitoring instruments shall have preselective trip settings, adjustable over the entire instrument range, with audible annunciators. They shall provide electronic signals for remote alarms.

f. As required by ANSI/ANS-HPSSC, Section 5.5.5, The area radiation monitoring alarm setpoints shall be controlled to prevent accidental or erroneous adjustment.

g. Local and remote fault alarms shall be provided.

h. UPS shall be able to supply backup power for at least 1 hour per ANSI/ANS-HPSSC, Section 5.3 .

i. Pursuant to Sections 4.9.2 and 4.9.3 of ANSI N13.6-1972, ANSI Standard on the Practice for Occupational Radiation Exposure Records Systems, and Article 703 of 10 CFR 835, the MCS shall provide a chronological, historical record. Data logs shall be recorded and archived.

6.12.4.2 Continuous Air Monitoring System. Continuous air monitoring equipment shall be installed in frequently occupied areas where a person without respiratory protection is likely to be exposed to radioactive contamination levels in air exceeding 1 derived air concentration per hour $(\mathrm{DAC} / \mathrm{h})$ or where there is a need to alert potentially exposed workers to unexpected increases in the airborne radioactive contamination levels. Continuous air monitoring requires monitoring at $2 \%$ of allowable limit of intake of any isotope and "real time" with alarm capabilities at 1 DAC.

a. Continuous air monitors shall be provided in accordance with HSRCM-1 to continuously monitor airborne beta/gamma radioactivity levels, higher than normal background of representative breathing air zones for full-time access areas, air ventilation system exhausts, any area where a system vents through a HEPA filter or has a rupture or relief system, and the radioactive waste container storage areas. Alpha monitoring shall also be provided.

b. Continuous air monitors shall provide audible and visible high airborne radioactivity alarm indication locally.

c. The number and proposed locations of continuous air monitors shall be included in the design but actual placement will be determined based on source terms, high-risk component placement, actual building air flow patterns, and actual traffic patterns.

d. The continuous air monitors shall be capable of adjustable setpoints detecting contamination. The alpha monitors shall be capable of measuring alpha particles with energies $>3.5 \mathrm{MeV}$. The beta monitors shall be capable of adjustable setpoints 
measuring beta radiation ranging from $0.08 \mathrm{MeV}$ to $3.0 \mathrm{MeV}$ and count rates from 10 to $10,000 \mathrm{cpm}$.

- Beta

Uses 2-in. Or 47-mm filters

Log scale 10-100K CPM

Capable of seeing $8 \mathrm{DAC} / \mathrm{h}$ laboratory conditions

Local alarm both audible and visible.

- Alpha

Uses 2-in. Or 47-mm filters

Log scale 10-10K CPM

Local alarm both audible and visible

Capable of seeing $8 \mathrm{DAC} / \mathrm{h}$ in laboratory conditions.

e. The mean instrument response of the continuous air monitors and record samplers shall not vary more than $15 \%$ in the normal temperature range of $10^{\circ} \mathrm{C}$ to $40^{\circ} \mathrm{C}$ $\left(50^{\circ} \mathrm{F}\right.$ to $\left.104^{\circ} \mathrm{F}\right)$ and shall not vary more than $20 \%$ in the extreme temperature range of $-20^{\circ} \mathrm{C}$ to $50^{\circ} \mathrm{C}\left(-4^{\circ} \mathrm{F}\right.$ to $\left.122^{\circ} \mathrm{F}\right)$ from the mean instrument response at $22^{\circ} \mathrm{C}$ $\left(72^{\circ} \mathrm{F}\right)$.

f. The continuous air monitors and record samplers shall be capable of operating with an electrical ac supply ranging from $102 \mathrm{~V}$ ac to $132 \mathrm{~V}$ ac and a frequency range of 57 to $61 \mathrm{~Hz}$. Continuous air monitors shall be able to continue operation during power fluctuations.

g. Smoke testing shall be performed and documented after installation to verify that the continuous air monitor and record sampler locations are optimum. Allowances shall be made for replacement based on the smoke test.

\subsubsection{Personnel Contamination Monitors.}

a. Personnel contamination monitors shall be provided at entrances to the process area for personnel monitoring and contamination control.

b. Personnel monitors shall provide local and remote indication of contamination level. Minimum design features shall include the following:

- Detect beta/gamma radiation

- Sound a local audible alarm

- Include local fault alarms. 
c. The personnel monitor sensitivity shall be consistent with the different isotope sensitivities of Table 2-2 of HSRCM-1. Monitoring for contamination shall be performed using frisking equipment that, under laboratory conditions, can detect total contamination of $5000 \mathrm{dpm} / 100 \mathrm{~cm}^{2}$ for beta/gamma emitters. The requirement for monitoring contamination that under laboratory conditions can detect total contamination of at least the values specified in HSRCM-1, Table 2-2, is found in Article 221 of HSRCM-1. HSRCM-1 also recommends the use of automatic monitoring units.

\subsubsection{Stack Monitoring System.}

a. The stack monitoring system shall directly monitor for the emission of alpha-emitting particles and indirectly for beta/gamma-emitting particles and gases.

b. High discharge levels of the directly monitored nuclides shall cause the system to alarm and notify the MCS to take appropriate mitigation actions.

c. The system shall contain both real-time continuous monitoring of alpha-emitting particles and off-line monitoring for ${ }^{129} \mathrm{I}$, and alpha- and beta/gamma-emitting particles. Standard, approved, off-line techniques shall be provided to identify concentration of various isotopes (e.g., ${ }^{239} \mathrm{Pu},{ }^{241} \mathrm{Am},{ }^{129} \mathrm{I},{ }^{137} \mathrm{Cs},{ }^{137} \mathrm{Ba},{ }^{90} \mathrm{Sr},{ }^{90} \mathrm{Y}$, and other fission products associated with the $\mathrm{SNF}$ ).

d. The sampling and monitoring system shall be designed to collect $10-\mu \mathrm{m}$ particles with a $50 \%$ efficiency (minimum).

e. The stack flow rate shall be automatically measured using devices that are certified in accordance with 10 CFR 52, Appendix E.

f. The exhaust air temperature shall be measured with an accuracy of $\pm 1{ }^{\circ} \mathrm{C}$. The stack monitoring system shall meet the requirements of WAC 246-247-075, DOE Order 6430.1A (Section 1589-99.0.1), and ANSI N13.1.

g. Shrouded sampling probes requirements are as follows:

1. Sampling Location

The sampling locations must be selected to ensure that flow profiles are well characterized and that sampling is representative of all stack effluents. The measurement site must be qualified for single point representative sampling by demonstrating complete mixing across the entire flow profile by

i. Measuring the velocity profile

ii. Measuring for complete mixing with an appropriate tracer gas 
iii. Measuring for complete mixing of tracer particulate in stacks where particulate contaminants could be present.

The coefficient of variation of the velocity profile and test tracers each must not be greater than $\pm 20 \%$ over the central two-thirds of the area of the duct. Over the complete profile, the tracer gas concentration must not be greater than $\pm 30 \%$ of the mean concentration across the duct. EPA 40 CFR 60, Appendix A, Method 1, must be used to determine the number of measurement points in each sampling grid.

In instances where all of these criteria are not satisfied initially, exhaust stream mixing must be enhanced by appropriate measures (e.g. installing mixing elements, adding elbows, rearranging entrances in different planes, and preventing the introduction of lateral flows flush with the side wall of the receiving duct). The objective of such modifications is to avoid particle stratification, ensuring complete mixing, minimizing particle entrapment in flow boundary layers, and avoiding regions of unusually high concentrations.

Following these modifications, the system must be tested again to verify that all standards and criteria are met.

2. Shrouded Probe Design

For each release point under consideration, the shrouded probe must be designed to meet all expected stack operating specifications, including exhaust velocity and sampling flow rates over the range of anticipated conditions. The shrouded probe must be designed for and operated at a qualified sampling location in a well mixed and stable effluent flow profile.

Each use of a shrouded probe must satisfy the following conditions.

i. The transmission ratio of the probe must be between 0.80 and 1.3 for $10 \mu \mathrm{m}$ aerodynamic diameter aerosol particles, where the transmission ratio is defined as the ratio of the particulate concentration delivered by the probe at the entrance of the sample transport line to the free-stream particulate concentration.

ii. The overall frontal area of the probe must not exceed $15 \%$ of the duct or pipe internal cross-sectional area.

iii. Use of the probe must be limited to pipes and ducts with an internal diameter of 3 inches.

iv. For cyclonic or swirling flows, use of the probe must be limited to pitch and yaw angles of $20^{\circ}$ in accordance with 40 CFR Part 60, Appendix A, Method 1. 
v. The sampling flow rate must be maintained at $\pm 25 \%$ of design specifications over the range of anticipated conditions.

vi. The probe is used at a sampling site where the particle size, as determined by either direct measurements or analytical means, is within the range for which the probe was calibrated.

The specifications of each shrouded probe must be fully documented, starting with the initial design requirements, manufacturing, and testing, and installation at the point of use. Each probe must be stamped with the following information: model number, serial number, and nominal and range of operating conditions. The documentation package must provide al 1 information necessary to identify the original requester and the probe manufacturer, to address all design requirements, manufacturing, and testing. The testing criterion for each new probe must be $\pm 7 \%$ of mean value (of the transmission ratio) between the wind tunnel test results and model calculations for the nominal operating conditions with $10 \mu \mathrm{m}$ aerodynamic equivalent diameter particles.

3. Optimization of Sample Transport Line

The design of the sample transport lines must be optimized to reduce the number of bends, elbows, long horizontal and vertical runs, and total run lengths from the probe to the sample collection medium for the designed sampling flow rate, Transport the diameters must also be optimized. The DEPOSITION computer code must be used to estimate particulate deposition in the line between the shrouded probe and the collection device and to account for line losses in the calculation of the source term. (Other methods or computer codes which are shown to be equivalent to or better than the DEPOSITION code may be used to assess the overall performance of the system with the prior approval of the U.S. Environmental Protection Agency.)

The following specifications must be met.

i. The overall performance of the system, from the sampling probe to the sample collection medium, must be shown by the DEPOSITION code to be $50 \%$ for $10 \mu \mathrm{m}$ aerodynamic equivalent diameter aerosol particle at the nominal sampling flow rate and free stream velocity.

ii. For sampling conditions within the range of $0{ }^{\circ} \mathrm{C}$ to $50^{\circ} \mathrm{C}\left(32^{\circ} \mathrm{F}\right.$ to $122^{\circ} \mathrm{F}$ ), Version 2.01 or newer of the DEPOSITION code must be used. For temperature conditions outside of this range, Version 2.02 or newer, must be used.

iii. For gas mixtures other than air, the DEPOSITION code cannot be used unless adjustments are made for the given mixture. 
6.12.4.5 Room Air Quality Monitoring System. The process bay atmosphere shall monitored and local and remotely alarmed via the MCS for low oxygen

\subsubsection{Safety Performance Requirements}

No safety performance requirements are applicable because all equiment and equipment performance is classified as general services.

\subsubsection{Codes, Standards, and Source Documents}

The codes and standards applicable to the design of SSCs are listed in Table 6-2.

\subsection{MONITORING AND CONTROL SYSTEM-FACILITY}

\subsubsection{Location, Boundaries and Interfaces}

The MCS serves both facility and process control functions and as such is discussed in detail below as a facility system.

6.13.1.1 Location. The MCS operations work stations shall be located in the CVDF control room. The supervisor work station shall be located in the shift operations office. All remote $1 / O$ locations shall be located in accessible locations near the process they monitor.

6.13.1.2 Boundaries. The boundary of the MCS includes all components starting at the computers and ending at the wiring terminations at the skids, sensors, or the equipment. The actual sensor and equipment, including electrical contactors, are outside the MCS boundary.

6.13.1.3 Interfaces. The MCS is the primary control system for CVDF and interfaces with all subsystems that have instruments or controls, except fire protection. Some interfaces are provided with all control functions for the system operation while others, for example the HVAC system, have local control with limited interfaces to the MCS. For safety systems, the interfaces will be isolated as required in the safety sections of this DRD. This futher interates the requirement that the MCS perform no safety functions. Monitoring, however, of safety parameters may be performed as allowed by administrative controls.

The following subsystems shall interface with the MCS as outlined in the following requirements. As the design for the actual interfacing system continues, further interfaces development will occur. 


\subsubsection{Facility Functional Requirements}

a. The MCS shall provide monitoring, alarm, and supervisory control functions for the CVDF and process mechanical and electrical systems. The system shall be capable of providing information on all system instrumentation, alarms, mechanical equipment status, trending, and historical data.

b. The MCS system shall be an interactive system with multiple operator, engineering, and supervisor workstations networked on a redundant, real-time data transfer and communication system.

c. MCS data will be processed as real-time data capable of alarm generation, data transformations, control algorithms, linearizations, status checking, and sequence of event processing.

d. The MCS shall be cost-effective for the quantity of inputs and outputs provided.

e. The MCS, by its failure, action, or inaction, shall not jeopardize worker or plant safety. Neither safety-significant nor safety-class equipment shall be degraded by the MCS.

f. Standardization between the Hot Conditioning System subproject and the CVDF shall be implemented to the extent possible. The MCS hardware, programmable logic controller, computers, software, and communication shall be consistent with the Hot Conditioning System controls.

g. The operator interface shall be through user-configurable workstations providing interactive graphics-based process information and facility controls, alarm annunciation and acknowledgment, historical data retrieval, trending reports, priority alarm screen or window, and network information.

h. The design of equipment shall incorporate the objective of efficient maintainability. The surveillance, testing, and maintenance of a system and its restoration to operational effectiveness shall be achieved at minimum costs with a minimum level of support services (DOE Order 6430.1A, Section 1300-12.4.10).

i. Human factors engineering shall be incorporated as required by DOE Order 6430.1A, Section 1300-12. A human factors engineering program plan shall be generated in accordance with DOE Order 6430.1A, Section 1300-12.3.2. 


\subsubsection{Safety Functional Requirements}

There are no safety functions performed by the MCS. The MCS does however interface with safety subsystems but by design cannot prevent the safety systems from performing their safety functions.

\subsubsection{Functional Performance Requirements}

a. The MCS shall be designed to accommodate all facility and process system input and output points. A $25 \%$ spare capacity for additional $\mathrm{I} / \mathrm{O}$ cards and termination racks, for future expansion, shall be provided.

b. Data acquisition shall be by modular-type, high-speed bus capable of handling discrete, analog, pulse, and thermocouple or resistance temperature detector signals on multipoint termination boards.

c. The MCS equipment and software shall have a proven design and at least 2 years of widespread industry use.

d. The MCS shall meet the expected environmental conditions for various equipment locations (refer to Table 5-1). Any required cooling shall be provided as required to ensure reliable system operation.

e. The requirements as stated in WHC-CM-4-2, QR-19, shall be followed to meet software verification and validation. In addition the minimum software documentation shall be provided, including the Computer Software Requirements Specification, Computer Software Design Description, and the Computer Software User Document.

f. Color coding of component status and visual displays shall be in accordance with Hanford Site procedure GE-COLR-01, "Color Coding - Component Status, Visual Displays, and Conductors."

g. Redundancy shall be utilized to meet process performance requirements. Multiple operation stations shall be used; should one workstation be lost, a loss of monitoring capability shall not occur. For computer databases, at least two work stations shall contain a complete and routinely updated database of all parameters and programs, automatically.

h. Color displays shall be used to provide easy-to-read graphics information presented in a manner to minimize operator errors, provide clear indications, and to allow higher priority indications be emphasized. The minimum screen resolution shall be $800 \times 600$ pixels and 256 colors. 
i. Instrumentation connections to and from the MCS shall be shown on the piping and instrumentation drawings.

j. The capability to connect a laptop computer at each programmable logic controller remote $\mathrm{I} / \mathrm{O}$ shall be provided. This provision shall allow local control of the respective equipment (i.e., the VPS, PWC, or auxiliary systems). A method shall be developed to prevent operation of noninvolved equipment (i.e., other bays or equipment).

k. Construction installation instructions for all MCS equipment shall be provided.

1. Instrumentation and $\mathrm{I} / \mathrm{O}$ lists (database and spreadsheets) shall be provided for all CVDF signals to and from the MCS.

m. For those remote devices that contain a local/remote (MCS) control switch, a means shall be provided to inform the control room when the switch is out of the remote position. The alarm routine may be used as a lower priority alarm signal.

n. The operator interface shall be through user-configurable workstations providing interactive graphics based process information and facility controls, alarm annunciation and acknowledgment, historical data retrieval, trending reports, priority alarm screen or window, and network information.

o. The MCS operator workstations and equipment shall be selected and arranged for best operator performance and comfort. Furniture shall be provided that is modular in design and constructed for use with computers. Space and storage for operating procedures shall be provided next to the keyboard and monitor. The control room shall be large enough to accommodate the MCS hardware without crowding.

p. A management information station (supervisor work station) shall be provided which has the capability for "read only" and printing of any and all MCS displays.

q. Color graphics printing capability shall be provided. The average printout time for a full screen print shall be no greater than 3 minutes. There shall be no dedicated alarm printer; on-demand printing of alarm history shall be accomplished on the graphics printer.

r. The operator workstations shall include hardware and software for the collection and storage of statistical process and facility historical data onto disk storage devices. Reports can be configured and automatically scheduled for printing or archiving. These stations shall be the primary operator control stations for all day-to-day activities. All information required to efficiently operator the CVDF shall be provided at these stations. 
s. Data collection shall be backed up on removable hard drives in an approved standard industry format. Microsoft Excel ${ }^{1}$ is an acceptable format.

t. The use of hardwired or software interlocks shall be determined during specific system design development. The MCS shall provide software interlocks via the programmable logic controller or the man-machine software where hard interlocks are not required and an interlock function is required.

u. Warning and alarm systems shall be designed, installed, and tested to ensure that they can be heard in the ambient conditions of the area they are intended to cover.

v. Any specific alarm stimulus shall have only one meaning. It can either designate one problem or it can be a signal to look at a particular location to define the alarm further. When there are many annunciator alarms, priority coding shall be used to assist in determining message significance.

w. Provision shall be made for active acknowledgment and for silencing of auditory alarms after they have been acknowledged via the operator workstations only. The EWS primary function is to serve as a report and printout generator, and at times, this station may be used by nonoperators. A potential use of this control room workstation may be as a third operator workstation. Strict password controls shall separate these potential functions.

x. Provision shall be made for maintaining personnel awareness of alarm conditions until they have been corrected or "cleared." Clearing of the alarm shall require a positive response from the assigned personnel.

y. Provisions for routine alarm annunciators tests shall be provided.

z. The full extent and requirements of the alarm system, as met by the MCS, shall be fully described in the Computer Software Requirements Specification. This document shall be developed in accordance with WHC-CM-4-2, QR-19, as part of the procurement package.

aa. Audible alarms (e.g., annunciator horns) shall be distinctive and uniformly applied. Bells as audible devices shall not be used.

bb. A blinking light or a blinking message on a cathode ray tube display shall denote a signal that is out of normal operating limits.

cc. The alarm sequence shall be identified according to ISA Standard S18.1.

${ }^{1}$ Excel is a trademark of the Microsoft Corporation. 
dd. A master list of alarms and setpoints shall be maintained for the entire facility.

ee. Expected operational sequences, interlocks, and alarm and off-normal MCS responses shall be determined and provided.

ff. Power for the MCS shall be provided by a UPS that is fed from normal facility power.

gg. Detection of a loss of normal power and a loss of UPS power shall be provided.

hh. Requirements as outlined in Section 6.13, "Electrical Power Distribution and Lighting System," shall be applied as relevant to the MCS power, wiring, grounding, and conduit.

ii. Power available for the MCS shall be provide by a UPS at $120 \mathrm{~V} \mathrm{ac}$, single-phase. Load capability of the UPS shall be sufficient to allow at least 4 hours of MCS operation on loss of normal facility power.

jj. A remote audible alarm shall be provided in the radiation protection room from the MCS. A provision shall be provided to silence this annunciator in this room. The alarm annunciation shall occur when any radiation alarms is received into the MCS, other plant alarms shall not be alarmed. The annunciator shall be a low sound level of approximately 55 to $70 \mathrm{~dB}$.

\section{6,13.5 Safety Performance Requirements}

The safety, performance, and environmental requirements listed in Tabel 6-13 shall be met.

Table 6-13. Monitoring and Control System Design Requirements.

\begin{tabular}{|l|c|c|c|}
\hline Components & $\begin{array}{c}\text { Safety } \\
\text { classification }\end{array}$ & $\begin{array}{c}\text { NPH } \\
\text { performance } \\
\text { category }^{1}\end{array}$ & $\begin{array}{c}\text { Environmental } \\
\text { qualification } \\
\text { (see Table 5-3) }\end{array}$ \\
\hline MCS (all items) & General services & PC-2 & 1 \\
\hline
\end{tabular}

MCS = monitoring and control system.

$\mathrm{PC}=$ performance category 2 .

\subsubsection{Codes and Standards}

Table 6-14 provides a list of MCS specific codes and standards. These industry standards shall be utilized. 
Table 6-14. Codes and Standards Applicable to the Design of the Cold Vacuum Drying Monitoring and Control System.

\begin{tabular}{|c|c|c|}
\hline Document title & Symbol/number & Area of coverage \\
\hline Code of Federal Regulations, Title 47 & $\begin{array}{l}\text { Federal Communications } \\
\text { Commission }\end{array}$ & Electrical \\
\hline Approval Guide & Factory Mutual & Electrical \\
\hline Instrumentation Symbols and Identification & ISA S5.1-1984 (R1992) & Symbol documentation \\
\hline $\begin{array}{l}\text { Graphic Symbols for Distributed } \\
\text { Control/Shared Display }\end{array}$ & ISA S5.3-1983 & Computer screens \\
\hline Instrument Loop Diagrams & ISA S5.4-1991 & Input / output documentation \\
\hline Graphic Symbols for Process Displays & ISA S5.5-1985 & Computer screens \\
\hline Annunciator Sequences and Specifications & ISA S18.1-1979 (R1992) & Annunciation \\
\hline $\begin{array}{l}\text { Specification Forms for Process } \\
\text { Measurement and Control }\end{array}$ & ISA S20-1981 & Input / output devices \\
\hline $\begin{array}{l}\text { Human System Interface Design Review } \\
\text { Guidelines }\end{array}$ & NUREG-0700 & Human factors \\
\hline National Electrical Code & NFPA 70 & Electrical \\
\hline Product Directories & UL & Electrical \\
\hline
\end{tabular}

ISA = Instrument Society of America.

\subsection{ELECTRICAL POWER DISTRIBUTION AND LIGHTING SYSTEM}

\subsubsection{Location, Boundaries and Interfaces}

6.14.1.1 Location. The electrical power system is located throughout the interior and exterior of the CVDF. The majority of the power distribution system shall be located in an separate electrical equipment room.

6.14.1.2 Boundaries. The boundary of the electrical power system is from the $13.8 \mathrm{KV} / 480 \mathrm{~V}$ transformer on the $480 \mathrm{~V}$ side to the terminations on the skid or equipment termination board.

6.14.1.3 Interfaces. The electrical power system interfaces with all powered systems inside and within the outside boundaries of the CVDF. 


\subsubsection{Facility Functional Requirements}

The electrical power system shall include

- Electrical supply for the CVDF

- Electrical power distribution systems

- Interior and exterior lighting

- Grounding

- Lightning and surge protection

- UPS.

\subsubsection{Safety Functional Requirements}

There are no safety functions performed by the electrical power system. The electrical power system does however interface with safety systems to provide non-safety power. Should safety-class or safety-significant power be required, this function shall be provided by the system requiring power.

\subsubsection{Functional Performance Requirements}

\subsubsection{Environmental Requirements.}

a. All equipment enclosures and raceway systems used for electrical components and the wiring distribution shall be environmentally suitable for the locations in which they shall be placed.

b. Each room or physical area shall be considered individually in determining its classification, depending on the properties and quantities of the potential radioactive contamination, vapors, liquids, gases, chemicals, combustible dusts, or fibers that may be present.

c. Special precautions shall be designed into the system for all areas with corrosive or hazardous atmosphere. It is possible that upset process conditions could allow the MCO atmosphere within the process hood and the exhaust stream to have hydrogen concentration in excess of the lower explosive limit.

\subsubsection{Power Requirements.}

a. The primary voltage for distribution of normal power for the CVDF will be a $13.8 \mathrm{kV}$ feeder provided within $18 \mathrm{~m}(60 \mathrm{ft})$ of the facility. The CVDF shall contain transformers and switch gear to derive and feed the voltages to be distributed in the CVDF. 
b. General-use power shall be provided by multiple circuits of $208 / 120 \mathrm{~V}$ single-phase or $208 \mathrm{~V}$ three-phase power.

c. The $120 \mathrm{~V}$ ac single-phase power shall originate from panelboards located in adjacent areas.

d. The $208 \mathrm{~V}$ ac single-phase and three-phase power shall originate from panelboards also located in adjacent areas.

e. Equipment requiring $480 / 277 \mathrm{~V}$ power shall be fed from local power panelboards for process bay areas and routed specifically to the individual load.

f. Non-process related equipment requiring $480 / 277 \mathrm{~V}$ power shall be fed from centrally located power panelboards and routed specifically to the individual load.

\subsubsection{Transformers.}

a. Oil-filled, insulated transformers shall be located outside of buildings or inside in approved transformer vaults. Unless additional protection is provided as specified below, transformers shall have a minimum distance separating them from buildings as shown in Table 6-15. The kVA rating is the total rating of all transformers unless the transformers are more than $9 \mathrm{~m}(30 \mathrm{ft})$ apart, in which case the rating is the unit rating.

Table 6-15. Minimum Distance Separating

Transformers from Buildings.

\begin{tabular}{|c|c|}
\hline \multicolumn{2}{|c|}{ Minimum Separation } \\
\hline Rating $(\mathrm{kVA})$ & Distance $(\mathrm{ft})$ \\
\hline$<75$ & 10 \\
\hline 76 to 333 & 20 \\
\hline 334 to 4,999 & 30 \\
\hline
\end{tabular}

b. Distribution transformers shall be indoor, dry-type, with $480 \mathrm{~V}$ delta-connected primaries.

c. Secondaries shall be $208 \mathrm{Y} / 120 \mathrm{~V}$ or $480 \mathrm{Y} / 277 \mathrm{~V}$ as required, three-phase, with the neutral solidly grounded.

d. Each transformer shall have four $2.5 \%$ full capacity taps, two above and two below rated primary voltage. 


\section{HNF-SD-SNF-DRD-002 REV 1}

e. Whenever possible, transformers shall be located adjacent to their associated panelboards.

\subsubsection{Building Separation.}

a. All building walls within the minimum distance shall be of masonry construction unless separated by a 2 -hour rated barrier wall. No unprotected walls or building openings shall be within the minimum distance.

b. Outdoor combustible liquid insulated transformers, $500 \mathrm{kVA}$ and larger, shall be provided with fire protection: at least one hydrant, connected to an adequate water supply, with standard hose house and UL-approved A-B-C fog nozzles in the immediate vicinity, or at least one $135-\mathrm{kg}(300-\mathrm{lb})$, wheeled, dry chemical extinguisher.

\subsubsection{Service and Distribution Equipment.}

a. Generally, conventional kilowatt-hour meters are appropriate for measuring and recording electrical energy use at the incoming power service to the building. Where a facility load management program is used individually for the facility or as a part of a site load management program, demand $(\mathrm{kW})$ metering capability shall also be provided.

b. In the selection of metering devices, consideration shall be given to their compatibility for use with an existing or projected energy MCS.

c. The $480 \mathrm{~V}$ switchgear shall consist of assemblies of free-standing, vertical, dead front, steel structures containing power buses, a ground bus, drawout power circuit breakers, necessary auxiliary control devices, instrument transformers, relays, meters, and control and meter switches. The switchgear shall be metal-enclosed suitable for indoor installation.

d. The power bus shall be isolated or insulated such that bare bus bars will not be exposed when a door is opened or a rear panel is removed.

e. Circuit breakers will be drawout, air break electrically, or manually operated as required, with stored energy-type operators.

f. Breakers will have solid-state trip units with selective characteristics to facilitate overload and short circuit protection and system coordination.

g. From the $480 \mathrm{~V}$ switchgear, power will be distributed to motor control centers.

h. The switchgear columns will be labeled alphabetically and the rows will be numeric. 
g. Branch circuit breakers shall be of the bolt-on thermal magnetic, molded case, overload and short circuit-type with a minimum trip rate of 15 amp and a minimum interrupting rate of $10,000 \mathrm{amp}$ for $120 / 208 \mathrm{~V}$ branch circuits and $14,000 \mathrm{amp}$ for $277 / 480 \mathrm{~V}$ branch circuits.

h. The use of molded case circuit breakers in panelboards shall be limited to no greater than the 400 amp trip rating size.

i. Main circuit breakers shall be installed on all panelboards.

j. Disconnect switches shall be provided for all motors and located within sight of the motor-driven device.

k. Disconnect switch handles shall be designed for padlocking in the "off" position.

1. Panelboards for $480 / 277 \mathrm{~V}$ ac and $120 \mathrm{~V}$ ac supply shall be located in each of the process bays and in the office area electrical room of the building, and shall be NEMA PB I circuit breaker type. Separate panelboards for general use, power and process bay loads shall be provided. The panelboards shall include the following minimum features:

1. Latch and tumbler-type lock on door of trim

2. Insulated neutral bar

3. A separate, uninsulated equipment ground bus

4. Twenty percent spare bus capacity in each panelboard for future loads in addition to loads identified during design

5. Twenty percent spare circuit breakers in each panelboard in addition to loads identified during design

6. Molded-case circuit breakers of the bolt-on type

7. Panelboards in accordance with the requirements of the NEC and UL.

m. Motor control centers shall be in accordance with NEMA ICS standards and UL 508 (DOE Order 6430.1A, -1640-2.5), metal-enclosed, free-standing, dead-front, with type I enclosure and type B, class I wiring.

n. Starters for $460 \mathrm{~V}$, three-phase motors shall be combination-type consisting of an adjustable instantaneous trip circuit breaker or motor circuit protector, a magnetic contactor with overload relays in each phase, and other necessary control devices. 
o. Motor control centers shall serve $460 \mathrm{~V}$ motors in the range of $0.5 \mathrm{hp}$ through $100 \mathrm{hp}$.

p. Minimum starter size shall be NEMA size 1. Minimum contactor size shall be NEMA size 0 . Control transformers shall be sized for $125 \%$ of the design connected load, with fused and grounded secondary.

q. Starters shall in general be suitable for full voltage starting except for those cases where reduced voltage or adjustable speed control is required.

r. Feeder circuits shall be protected by thermal magnetic circuit breakers.

s. The motor control center's columns will be labelled alphabetically and the rows will be numeric.

\subsubsection{Basis for Selection of Equipment and Feeder Ratings.}

a. Voltage levels, insulation levels, continuous current capacities, interrupting capacities, circuit protection, and mechanical strength shall be selected and coordinated in accordance with calculated values, standard levels for respective equipment, and the recommendations of the standards and codes.

b. Feeders to motor control centers, lighting transformers, and lighting and distribution panelboards shall match the rating of the associated equipment.

c. Demand factors applied in accordance with NEC and used as the basis for sizing power transformers and switchgear shall in general be as listed in Table 6-16.

Table 6-16. Demand Factors.

\begin{tabular}{|l|c|}
\hline \multicolumn{1}{|c|}{ Item } & Demand factor \\
\hline Lighting panelboards & 1.0 \\
\hline Distribution transformers & 0.75 \\
\hline Power receptacles & 0.1 \\
\hline Cranes & \\
\hline Largest motor & 1.0 \\
\hline Remaining motors & 0.5 \\
\hline All other motors & 1.0 \\
\hline
\end{tabular}


d. Feeder ampere ratings for motor control centers, dry-type transformers, and panelboards shall be based on the bus rating of the equipment.

e. Fault current rating of electrical equipment shall be selected to exceed the available fault current available to the individual equipment by a minimum of $20 \%$.

6.14.4.7 Electrical System Protection. System protective devices shall be selected and applied to minimize damage to the electrical system. These devices also shall limit the extent and duration of service interruptions due to overload or fault conditions. In addition, these devices shall be coordinated such that the interrupting device nearest the point of short circuit (or overload) will open first and minimize disturbances on the rest of the system (DOE Order 6430.1A, Sections 1630-2.1 and 1640-1.6).

Electrical system components shall be completely coordinated in regard to the following features:

- Short circuit capability

- Interrupting duty and capability

- Insulation levels

- Protective relaying

- Reliability

- Interchangeability

- Transformer and line voltage drop

- Stability under normal conditions

- Restart on power dips and outages.

6.14.4.8 Enclosures. Electrical enclosures shall be designed in accordance with NEMA 250 and suitable for the environmental conditions encountered (see Table 6-17).

Table 6-17. Electrical Enclosures.

\begin{tabular}{|l|l|}
\hline \multicolumn{1}{|c|}{ Area } & \multicolumn{1}{c|}{ Enclosure } \\
\hline Outdoor - general & NEMA 4, Weatherproof \\
\hline Indoor - general & NEMA 1, General purpose \\
\hline Indoor - subject to dust & NEMA 12 \\
\hline Indoor - subject to decontamination & NEMA 4X, Watertight, corrosion resistant \\
\hline $\begin{array}{l}\text { Areas considered hazardous } \\
\text { as defined by Article 500 of the NEC }\end{array}$ & NEMA 7 \\
\hline
\end{tabular}

NEC $=$ NFPA 70, National Electrical Code, National Fire Protection Association, Quincy, Massachusetts. 
6.14.4.9 Spare Capacity. The spare capacities noted in this section shall be available at the completion of the design.

a. Switchgear bus capacity will accommodate the maximum transformer loading.

b. Batteries for the UPS will be sized such that the maximum identified load on these systems will be $75 \%$ of the system capacity.

c. UPS inverters shall be sized such that the maximum identified load on this system will be $75 \%$ of the system capacity.

d. Distribution and lighting panelboards will be sized for an additional future load of $25 \%$ of the initial operating load.

e. Above-the-ground conduit runs or racks containing four or more conduits on a level shall be provided with a minimum of $152 \mathrm{~mm}$ ( $6 \mathrm{in}$.) of space for future use. Conduit runs or racks with less than four conduits on a level shall be provided with space for one future conduit equal to the largest conduit on the rack. Where the design indicates that future access for installation of conduit is blocked, spare conduit shall be provided in the initial installation.

f. All terminal boxes (except motor terminal boxes) shall be so designed as to have sufficient termination points to terminate all conductors entering the box and an additional $25 \%$ for future conductors.

g. All multiconductor and multipair instrument and control cable shall have $20 \%$, or a minimum of 2 pairs or 4 conductors, of the total quantity of pairs or single conductors reserved for future use.

h. All underground ducts shall have a minimum of $25 \%$ spare conduits (DOE Order 6430.1A, Section 1630-2.2.3) but not less than two.

i. Underground pull boxes shall have a minimum of $25 \%$ spare space for conduits in each wall having one or more windows.

j. All distribution panels shall have a minimum of four spare circuit breakers.

k. The $480 \mathrm{~V}$ switchgear, switchgear bus section shall have a minimum of one spare breaker and one space.

1. Each motor control center shall have a minimum of the following spare feeder circuit breakers and motor starters:

- One spare circuit breaker for each four circuit breakers used

- One space for a future circuit breaker for each six circuit breakers used 
- One spare motor starter for each four motor starters used

- One space for a future motor starter for each six motor starters used.

m. The ratings of the spare circuit breakers and motor starters on each motor control center shall be in proportion to the quantity and rating of the active units.

6.14.4.10 System Voltage Drop Criteria. System voltage drop criteria and limits shall be as follows.

a. Load centers shall be directly connected to secondary switchgear with as near zero percent voltage drop as possible.

b. Transformer regulation shall not be considered for normal operating conditions because the transformer tap changers will be set to obtain a specified bus voltage level under normal load conditions.

c. Transformer impedance shall be considered for voltage drop calculations during starting of large motors and "grouped" motor reacceleration.

d. The allowable voltage drop in the cables during normal operation and based on full load conditions shall not exceed the values shown in Appendix A.

e. In general, the allowable voltage drop through the system to the source buses during motor starting shall not exceed the following limits:

- Five percent maximum on buses directly supplying motors ( $480 \mathrm{~V}$ motor control centers

- Fifteen percent at the motor terminals during starting.

f. Motor starting or reaccelerating voltage shall be, at all times, sufficient to produce the torque required to accelerate the load to rated speed. This stipulation applies in particular to motors controlled by starters equipped with devices that hold the starting circuit closed for a preset period of time so that motors will automatically reaccelerate after a momentary voltage dip.

6.14.4.11 Motors. Motors shall be in accordance with NEMA MG-1, squirrel-cage induction-type, with starting and running characteristics coordinated with the driven machine and the motor control equipment. (DOE Order 6430.1A, Section 1640-2.4). Motor horsepower and voltage ratings shall conform to the ratings in Table 6-18. Motors for rotating equipment will have local controls for testing and maintenance. 
Table 6-18. Motor Ratings.

\begin{tabular}{|c|c|c|}
\hline Horsepower & Motor nameplate & System \\
\hline Below $0.5 \mathrm{hp}$ & $115 / 1$ & $120 / 1$ \\
\hline $0.5 \mathrm{hp}-1 \mathrm{hp}$ & $208 / 3$ & $208 / 3$ \\
\hline $0.5 \mathrm{hp}$ and over & $460 / 3$ & $480 / 3$ \\
\hline
\end{tabular}

6.14.4.12 Power Factor. The general requirement is for the normal, standby, and emergency UPS distribution systems to meet a minimum design power factor of 0.95 . To achieve the 0.95 power factor, the following measures shall be considered.

a. For continuous-duty motors rated $20 \mathrm{hp}$ and larger, capacitors shall be installed and switched with the motor.

b. For continuous-duty motors rated $5 \mathrm{hp}$ and larger, the use of high-efficiency motors shall be considered.

c. Where utilization conditions permit, the use of variable speed controllers shall be considered.

6.14.4.13 Access and Working Space. Sufficient access to and working space about electrical equipment shall be provided to permit ready and safe operation and maintenance of such

equipment. Article 110 of NFPA 70 shall be used to determine the minimum access and working space.

6.14.4.14 Equipment Control Voltage Levels. Control voltage for the CVDF equipment shall be as follows.

a. Motor controllers, control circuits for motors shall be $120 \mathrm{~V}$, grounded systems.

b. Process equipment skids, control circuits shall be $24 \mathrm{~V}$, grounded system.

c. Facility packaged mechanical equipment, control circuits shall be $120 \mathrm{~V}$ ac, grounded system.

\subsubsection{Wiring.}

a. The wiring method known as "open wiring on insulators" (NEC Article 320) shall not be permitted for interior wiring.

b. Concealed knob-and-tube wiring (NEC Article 324) shall not be permitted for interior wiring. 
c. The wiring methods known as "nonmetallic-sheathed cable-types NM and NMC" (NEC Article 336), "service-entrance cable-types SE and USE" (NEC Article 338), and "underground feeder and branch-circuit cable-type UF" (NEC Article 339) shall not be permitted for interior wiring.

d. All conductors shall be UL-listed and insulations shall be fire resistant. Type THHN/THWN insulation shall be specified.

e. Conductors for class 1 remote control and signal circuits shall be enclosed in cable and shall comply with NFPA 70.

f. Conductors for class 2 low-energy remote control and signal circuits shall be not smaller than No. 18 AWG. Power and lighting conductors shall be $600 \mathrm{~V}$, type THHN/THWN or XHHW. Conductors required to be rated $90^{\circ} \mathrm{C}\left(195^{\circ} \mathrm{F}\right)$ in accordance with NFPA 70 shall be type RHH, THW, or THHN.

g. Conductors in high-temperature areas shall be NEC type FEP or TFE as required.

h. Bonding and grounding conductors shall be sized in accordance with NEC Article 250 .

i. The standard for all phasing and phase rotation shall conform to the existing site system. In general, the proper sequence for panels and switchgear is A-B-C from left to right, from top to bottom, front to back (as viewed from front, operating side) of buses, breakers, panels, and switchgear.

j. Conductors for interior electrical systems shall be copper.

k. Conductors for low voltage power and lighting branch circuits shall be No. 12 AWG, minimum, except flexible cords and flexible cables, not in conduit, which shall be No. 16 AWG, minimum.

1. Power conductors in conduit shall be No. 12 AWG, minimum.

m. Conductors for control circuits should be stranded copper, No. 14 AWG, minimum, except that crane and elevator circuits, remote control circuits, signaling circuits, power limited circuits, fire protection signaling systems, class 2 low-energy data acquisition signal circuits, instrumentation and communication circuits shall be sized in accordance with the NEC, Articles 610, 620, 725, 760, and 800 .

n. Conductors for class 1 remote control and signal circuits shall be enclosed in cable and shall comply with NFPA 70 . 
6.14.4.16 Conduit and Raceway. Selection and installation of raceways, elbows, couplings, and other fittings shall comply with the applicable sections of the DOE Order 6430.1A and the provisions of the NEC with the following restrictions.

a. Neither aluminum conduit nor electrical metallic tubing shall be embedded in concrete or buried in earth.

b. The wiring method known as "nonmetallic extensions" (NEC Article 342), "surface raceways" (NEC Article 352), and "multi-outlet assembly" (NEC Article 353) shall

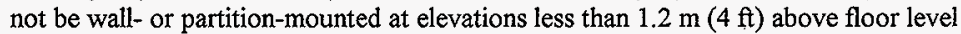
unless protected by running boards or the building finish from contact (e.g., by moving furniture, benches).

c. Conduit and other raceways embedded in concrete or masonry shall be adequate in number and capacity for the initial and projected facility requirements. Polyvinyl chloride conduit shall be allowable for concrete-embedded applications; however offsets and bends shall be metallic.

d. Electric metallic tubing also shall be considered for wider use, in lieu of rigid metal conduit or intermediate metal conduit, except where the conduit would be subject to severe physical damage such as below a $2.4-\mathrm{m}(8-\mathrm{ft})$ elevation in areas where forklifts or other vehicles operate, or corrosion damage, or where it would be embedded in concrete or buried.

e. Conduit installations shall not contain runs exceeding $61 \mathrm{~m}(200 \mathrm{ft})$ between pull points unless specifically approved.

f. Separate dedicated raceways shall be provided for each of the following systems: radiation and breathing air alarm, fire alarm, voice paging and building evacuation systems, telephone and data communication, and any other electrical systems as specified by the NEC.

g. Fittings and conduit bodies for both rigid galvanized steel and intermediate metal conduit shall be threaded and conform to NEMA FB-1 with material to match conduit. Pull boxes and junction boxes shall be NEMA 250, Type 4.

\subsubsection{Design and Installation Requirements.}

a. Adequate ground continuity shall be maintained for all metallic conduit runs. An insulated ground wire shall be located in all conduit runs. The conduit shall not be used as a ground conductor.

b. Raceways shall be designed with the required separations between systems in accordance with DOE Order 6430.1A. 
c. All spare ducts and conduits shall contain a pull rope to facilitate future installations. Conduits embedded in walls, ceilings and in or under floor slabs shall not be less than 0.75 in. in size.

d. Additional power distribution system capacity shall be designed into the system.

e. A minimum of 0.75 -in.-sized conduit shall be specified for interior installations.

f. All conduit raceway systems entering the process bay areas and between floors shall be equipped with conduit seal-off fittings. All conduits containing wire or cables shall be sealed with an approved nonhardening compound. Spare conduits between these areas shall be sealed with an approved nonhardening putty-type compound.

g. Openings around electrical conduit penetrations through fire-rated walls, partitions, floor, or ceiling shall be fire-stopped using UL-approved methods.

h. All exposed raceways shall be provided with identification systems for maintenance and safety purposes. Raceways shall be identified with applicable markers at strategic locations to indicate such characteristics as the type of system and voltage for the circuit contained. Labeling shall be in accordance with Hanford Site standards.

i. The use of cable trays shall be considered for large multiple-cable applications. Separate trays shall be used for instrumentation and control applications. The use of cable trays in areas of potential contamination shall be avoided.

\subsubsection{Grounding.}

a. Ground characteristics at the Hanford Site are such that supplemental cable for ground grid or loops and attachment to well casings is required to satisfactorily reduce ground resistance. All underground metallic piping, all building structural steel and rebar, and all underground metallic conduit and ground cables at the building shall be tied into the building ground grid.

b. Equipment grounding conductors shall be provided in accordance with Article 250-57(b) of NFPA 70.

c. A green insulated ground conductor shall be required in all conduits containing general purpose circuits for equipment grounding.

d. A green with yellow stripe insulated ground conductor shall be used for any clean ground to a clean power system when such systems are used.

e. A minimum of a No. 12 AWG copper ground conductor size shall be used with low-voltage power circuits. 


\section{HNF-SD-SNF-DRD-002 REV 1}

f. Ground conductors shall be sized as a minimum in accordance with NFPA 70 and IEEE 142 .

g. All structural steel, bottled gas racks, tanks, mechanical equipment, and other metallic systems shall be grounded.

h. A clean ground shall be required for any clean power system in accordance with NEC-250-5.

i. Raceway systems shall not be used as a ground path.

\subsubsection{Outlets and Receptacles.}

a. Wall-mounted duplex convenience outlets shall be provided in all rooms in accordance with NFPA 70.

b. General outlets shall be NEMA type 5-20R. Special receptacles, color-coded orange, shall be specified for any clean power outlets.

c. All outlets shall be labeled for voltage above $120 \mathrm{~V}$ ac with the applicable voltage and number of phases.

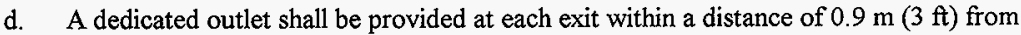
the door for support of portable monitors.

e. Convenience outlets for the process bays shall consist of $115 \mathrm{~V}$ ac, three-prong grounding outlets, NEMA-15 R. Wiring shall be hermetically sealed.

f. Receptacles within $1.8 \mathrm{~m}(6 \mathrm{ft})$ of sinks, located within enclosures with sinks, or in any other area where sinks are present shall be provided with ground-fault interrupter protection.

g. All outside receptacles shall be provided with ground-fault interrupter protection.

\subsubsection{Lighting.}

\subsection{General Lighting.}

a. Lighting shall be designed in accordance with the Illuminating Engineering Society Handbook. Illumination of the bays shall be accomplished by using metal halide fixtures mounted on the ceiling of the bay. Lighting level shall be 2.2 lux ( 0.2 foot candles) at the floor level.

b. Emergency lighting shall be from battery-operated automatic recharging, push-to-test lighting units and exit lights. 


\section{HNF-SD-SNF-DRD-002 REV 1}

c. Emergency exit lighting shall be provided in case of power failure.

d. All walkways, entrances, and exits shall be lighted.

e. Higher voltage lighting systems and higher efficiency lamp systems shall be used where practical.

f. Metal halide and fluorescent lamps will be used for interior lighting.

g. Emergency lighting shall be in accordance with the NEC, Section 700D, the UBC, and NFPA 101.

h. Lighting level shall be 8 lux ( 0.75 foot candles) for the process bay and 5.4 lux ( 0.5 foot candles) for the administration building at the floor level.

i. Lighting in the process bay mezzanine areas shall primarily consist of direct lighting from metal halide lamp fixtures.

j. Fixtures shall be selected and placed to light areas beneath the mezzanine not adequately illuminated from the ceiling-mounted fixtures.

k. Lighting level shall be $5.4 \mathrm{lux}$ ( 0.5 foot candles) minimum.

1. Outdoor lighting shall be metal halide fixtures mounted around the perimeter of the building where personnel or vehicle traffic will be encountered.

m. Exterior lights shall be installed over all doorways and exits. Security and obstruction lighting will not be required for the CVDF.

\subsubsection{Lightning Protection.}

a. Lightning protection systems shall be designed and installed in accordance with the recommendations and requirements of the latest issue of NFPA 78.

b. The building's trim, stairs, ladders, railings, structures, and siding, shall be of conducting material, continuous, and bonded to the building ground grid.

c. The downcomer grounding wire shall be covered to prevent staining of exterior building surfaces.

d. Conducting piping and ducting shall be continuous and bonded to the building ground. 


\subsubsection{Uninterruptible Power Supply.}

a. A central UPS system shall be provided for the radiation instrumentation, oxygen monitoring system, communication systems, special purpose receptacles, and for the process and facility control system computers and remote programmable logic controllers. This UPS system shall be supplied from a central isolation transformer for clean power to these systems. Note that any security system UPS requirements will be meet by the security system.

b. The UPS shall be capable of supporting its connected loads for 4 hours of operation.

6.14.4.23 Emergency Power Connections. There are no emergency power connections.

\subsubsection{Safety Performance Requirements}

The safety, performance, and environmental requirements listed in Table 6-19 shall be met.

Table 6-19. Electrical Power System Design Requirements.

\begin{tabular}{|l|c|c|c|}
\hline Components & $\begin{array}{c}\text { Safety } \\
\text { classification }\end{array}$ & $\begin{array}{c}\text { NPH } \\
\text { performance } \\
\text { category }\end{array}$ & $\begin{array}{c}\text { Environmental } \\
\text { qualification } \\
\text { (see Table 5-3) }\end{array}$ \\
\hline EPS (all items) & General services & PC-2 & 1 \\
\hline
\end{tabular}

EPS = electrical power system.

$\mathrm{NPH}=$ natural phenomena hazard .

$\mathrm{PC}=$ performance category 2 .

\subsubsection{Codes and Standards}

The codes and standards applicable to the design of SSCs are listed in Table 6-2.

\subsection{REFERENCES}

ANSI/ASME B31.1-1986, 1986, Power Piping, American Society of Mechanical Engineers, New York, New York.

ANSU/ASME B31.9-1988, 1988, Building Services Piping, American Society of Mechanical Engineers, New York, New York. 
ANSI/ISA-S5.1-1984 (R1992), 1992, Instrumentation Symbols and Identification, Instrument Society of America, Research Triangle Park, North Carolina.

ANSI/ISA-S5.5-1985, 1986, Graphic Symbols for Process Displays, Instrument Society of America, Research Triangle Park, North Carolina.

ANSI/ISA-S18.1-1979 (R1985), 1985, Annunciator Sequences and Specifications, Instrument Society of America, Research Triangle Park, North Carolina.

ASME B31.3-1993, 1993, Chemical Plant and Petroleum Refinery Piping, American Society of Mechanical Engineers, New York, New York.

ASME B31.5-1992, 1992, Refriegeration Piping, American Society of Mechanical Engineers, New York, New York.

DOE Order 4700.1, 1992, Project Management System, U.S. Department of Energy, Washington, D.C.

DOE Order 5480.7A, 1993, Fire Protection, U.S. Department of Energy, Washington, D.C.

DOE Order 6430.1A, 1989, General Design Criteria, U.S. Department of Energy, Washington, D.C.

DOE-STD-1066-97, 1997, Fire Protection Design Criteria, U.S. Department of Energy, Washington, D.C.

GE-COLR-01, Color Coding-Component Status, Visual Displays, and Conductors, ICF Kaiser Hanford Company, Richland, Washington.

HNF-SD-SNF-FHA-003, 1997, Fire Hazard Analysis for the Cold Vacuum Drying Facility Building 142K, Rev. 1, Fluor Daniel Hanford, Incorporated, Richland, Washington.

ISA-S5.3-1983, 1982, Graphic Symbols for Distributed Control/Shared Display Instrumentation, Logic and Computer Systems, Instrument Society of America, Research Triangle Park, North Carolina.

NFPA 13, 1996, Standard for the Installation of Sprinkler Systems, National Fire Protection Association, Quincy, Massachusetts.

NFPA 15, 1996, Standard for Water Spray Fixed Systems for Fire Protection, National Fire Protection Association, Quincy, Massachusetts.

NFPA 24, 1995, Standard for the Installation of Private Fire Service Mains and their Appurtenances, National Fire Protection Association, Quincy, Massachusetts. 
NFPA 45, 1996, Standard on Fire Protection for Laboratories Using Chemicals, National Fire Protection Association, Quincy, Massachusetts.

NFPA 69, 1997, Standard on Explosion Prevention Systems, National Fire Protection Association, Quincy, Massachusetts.

NFPA 70, 1996, National Electrical Code, National Fire Protection Association, Quincy, Massachusetts.

NFPA 72, 1996, National Fire Alarm Code, National Fire Protection Association, Quincy, Massachusetts.

NFPA 80, 1995, Standard for Fire Doors and Fire Windows, National Fire Protection Association, Quincy, Massachusetts.

NFPA 90A, 1996, Standard for the Installation of Air Conditioning and Ventilating Systems, National Fire Protection Association, Quincy, Massachusetts.

NFPA 90B, 1996, Standard for the Installation of Warm Air Heating and Air Conditioning Systems, National Fire Protection Association, Quincy, Massachusetts.

NFPA 91, 1995, Standard for Exhaust Systems for Air Conveying of Materials, National Fire Protection Association, Quincy, Massachusetts.

NFPA 101, 1997, Life Safety Code, National Fire Protection Association, Quincy, Massachusetts.

NFPA 780, 1995, Standard for the Installation of Lightning Protection Systems, National Fire Protection Association, Quincy, Massachusetts.

NFPA 801, 1995, Standard for Facilities Handling Radioactive Materials, National Fire Protection Association, Quincy, Massachusetts.

NUREG-7000, Guidelines for Control Room Design Reviews, U.S. Nuclear Regulatory Commission, Washington, D.C.

WHC-CM-4-2, Quality Assurance Manual, Westinghouse Hanford Company, Richland, Washington.

WHC-SD-GN-DGS-30006, 1993, Seismic Design Guide for Safety Class 3 and 4 Equipment at the Hanford Site, Rev. 1-A, Westinghouse Hanford Company, Richland, Washington. 
HNF-SD-SNF-DRD-002 REV 1

\subsection{DESIGN AND OPERATIONAL READINESS DOCUMENTATION}

\subsection{GENERAL}

The body of DOE orders that regulate the design and the project management of the CVDF contain a number of requirements that can best be categorized under the heading of design and operational readiness documentation. The required functions are addressed below.

\subsection{AS-LOW-AS-REASONABLY-ACHIEVABLE REQUIREMENTS}

\subsubsection{Requirements}

Refer to Section 3.3.2 for applicable criteria on ALARA design features and administrative controls.

\subsubsection{As-Low-As-Reasonably-Achievable Analysis Documentation}

Documentation shall be provided that demonstrates optimization methods are used to ensure that occupational exposure is maintained ALARA. This process involves judgements to evaluate the appropriateness of ALARA protective measures based on the relative value of social, technical and economic factors. An ALARA/Optimization Analysis shall be prepared to evaluate occupational dose reduction features for the design of the CVDF.

An ALARA/Optimization Analysis shall contain the following elements as a minimum:

a. A detailed dose assessment that includes identifying and estimating the dose for the work tasks that involve radiation exposure for operation, maintenance, inspection and installation of equipment.

b. Comparison of dose assessment (checklist format) against criteria established in Section 3.3 .2 of this document.

c. Cost-benefit analysis and records of decision. (Recent trends in optimization methodology development have resulted in a multiattributed technique that is extensively discussed in the ICRP Publication 37, Cost-Benefit Analysis in Optimization of Radiation Protection, and Publication 55, Optimization and Decision Making in Radiological Protection).

d. Recommendations for reduction of radiation exposure or statement that design is ALARA. 
HNF-SD-SNF-DRD-002 REV 1

\subsection{HUMAN FACTORS REQUTREMENTS}

Human factors engineering shall be incorporated as required by the DOE Order $6430.1 \mathrm{~A}$, General Design Criteria, Section 1300-12. A human factors engineering program plan shall be generated in accordance with Section 1300-12.3.2.

The following codes and standards shall be applied to human factors engineering aspects of the CVDF design.

Table 7-1. Codes and Standards Applicable to Human Factors Engineering on the Cold Vacuum Drying Facility.

\begin{tabular}{|l|c|c|}
\hline \multicolumn{1}{|c|}{ Document title } & Symbol/number & Area of coverage \\
\hline $\begin{array}{l}\text { Human Factors Design Guidelines for Maintainability } \\
\text { of DOE Nuclear Facilities }\end{array}$ & UCRL 15673 & Guideline \\
\hline $\begin{array}{l}\text { Humon Engineering Design Criteria for Military } \\
\text { Systems, Equipment and Facilities }\end{array}$ & MLL-STD-1472E & Guideline \\
\hline
\end{tabular}

\subsubsection{Human Factors Analyses}

Human factors engineering analyses appropriate to the level of importance of the facility shall be developed during the system design process. Incorporation of human factors into the design shall be documented in the form of checklists.

A systems requirements analysis appropriate to the level of importance of the systems and the level of risk associated with system failure shall be preformed as an integral part of the deign. A variety of human factors engineering analysis techniques are discussed in NUREG CR-3331, Methodology for Allocating Nuclear Power Plant Control Functions to Human or Automatic Control.

7.3.1.1 Ergonomic Considerations. Equipment that is to be used by personnel shall be designed or selected to accommodate their body dimensions. This equipment shall include control panels, work tables and counters, enclosures, seating, storage, special clothing, and any other equipment designed for an operator. The design of equipment for personnel shall accommodate a wide variety of body dimensions. Recommended dimensions and other guidance for stand-up and sit-down consoles and other workstations, for accessibility of equipment and instrumentation, for furniture and equipment layout, and for traffic flow shall be within guidelines (ML-STD-1472E).

7.3.1.2 Standardization of the Working Environment. The design solutions shall establish standards that promote a "positive transfer of training" to the maximum extent practical. The design of unit controls, indicating devices, and gauges shall be the same throughout the facility for equipment performing the same function: 
7.3.1.3 Operations Considerations. The design shall consider a range of factors appropriate for the workstation, equipment, hazards, and the demands placed on the operators. Those workstations requiring constant use and high throughput that potentially stress the operators, require more training, and require the repetitive handling of many items shall be analyzed in greater detail. The categories of work used in the analysis shall rank the workstations to determine those that should be studied in greater detail. The following items shall be included in the design.

a. Adequate spacing shall be provided for work and maintenance.

b. Shared services shall be adequate and clearly identified.

c. Arrangement, controls, gauges, and alarms shall follow established standards.

d. Gauges and related controls shall be clearly associated.

e. Noise level shall not be excessive (permits normal conversation with others in the general area), normally $<65 \mathrm{~dB}$.

f. Audible alarms shall not conflict with building emergency system alarms.

g. Warning systems, both audible and signal lights, shall be clearly associated with equipment.

h. Shared alarms shall provide a method to localize problems in a timely manner.

i. Alarms shall provide adequate time to react and/or provide safe automatic shutdown.

j. Complex and/or unusually hazardous systems which require special training shall provide for control of use to authorized personnel (e.g., key switches, passwords).

k. Key switches shall trap the key in the "on" position.

1. Alarms shall have an "acknowledge" button and/or resets for audible alarms and a change of state for flashing alarm lights.

m. Labeling and abbreviations shall be clear and meet $\mathrm{K}$ Basin standards.

n. Switches and controls shall be designed and/or placed to prevent accidental activation.

o. Adequate lighting, safety, cost, and accessibility shall be appropriate for the operation to be performed.

7.3.1.4 Maintenance Considerations. The design of equipment shall incorporate the objective of efficient maintainability. The surveillance, testing, and maintenance of a system and its 
restoration to operational effectiveness shall be achieved at minimum cost with a minimum level of support services. UCRL-15673, Human Factors Design Guidelines for Maintainability of Department of Energy Nuclear Facilities, shall be considered for system design. Factors evaluated shall be appropriate for periodic use of the systems and equipment.

7.3.1.5 Repair Considerations. The CVDF systems and process equipment shall be evaluated to determine a list of repair operations that either present significant risk to maintenance personnel or limited accessibility in the facility, or that may cause extra frustration for the maintenance personnel. Design solutions shall be developed to address each case.

\subsection{OPERATIONS AND MAINTENANCE REQUIREMENTS}

\subsubsection{Operating and Maintenance Manual Requirements}

The design development process makes early decisions that set parameters concerning operating and maintenance procedures. Operations and Maintenance Manuals shall be written to capture these assumptions and establish a framework of text to be modified as the systems are tested and brought on-line. The manuals shall address the following elements:

1.0 INTRODUCTION

1.1 Overview

1.2 Terminology

1.3 References

2.0 SYSTEM DESCRIPTION

2.1 Function

2.2 Operation

2.3 Configuration

2.4 Requirements

2.5 Safety

3.0 COMPONENT DESCRIPTIONS

3.1 [Component Name]

3.X [Component Name]

4.0 INSTRUMENT DESCRIPTIONS

4.1 [Component Name] Instruments

4.X [Component Name] Instruments

5.0 CONTROL AND LOGIC

5.1 [Component Name] Control Loop

5.X [Component Name] Control Loop 


\subsection{OPERATING PROCEDURES}

6.1 [System Name] System Valve and Electrical Lineup for Operation

6.2 Start Up [System Name] System

6.3 Operate [System Name] System

6.4 Shut Down [System Name] System

6.5 Perform [System Name] System Emergency Procedure

6.6 Respond to [System Name] System Alarms

6.7 Perform [System Name] System Surveillance

6.8 [System Name] System Special Testing

6.X [System Name] System Valve and Electrical Lineup for Operation

7.0 OPERATING PARAMETERS

7.1 Normal Operating Parameters

7.2 Alarm Setpoints

8.0 MAINTENANCE PROCEDURES

8.1 Preventive Maintenance Procedures

8.2 Calibration Procedures

8.3 Mechanical Maintenance Procedures

8.4 Electrical Maintenance Procedures

8.5 Identify any Occupational Safety and Health Administration-Recognized Hazards Associated with Maintenance Work to be Preformed

\subsection{APPENDIX}
A. Drawings
B. Documents
C. Vendor Information

\subsubsection{Waste Management Plan}

A waste management plan shall be written to incorporate the waste handling requirements of DOE Order 6430.1A, Section 1300-8. The process systems shall minimize the production of waste at the source and minimize the mixing of radioactive and non-radioactive waste. The waste management system shall provide facilities and equipment to handle those waste safely and effectively. Volume reduction equipment for both liquid and solid waste shall be required where feasible and shall be designed for process capability and capacity commensurate with the types and quantities of waste expected. Waste handling areas shall comply with the standards of confinement and ventilation requirements commensurate with the potential for spreading contamination by the waste package/forms handled. Specific DOE design and operating requirements for radioactive wastes (high-level waste, low-level waste, and TRU) appear in DOE Order 5820.2A, Radioactive Waste Management. 


\subsubsection{Occupational Safety and Health Administration Requirements and Checklist}

All designs are to meet applicable requirements of the Occupational Safety and Health Administration standards (29 CFR 1910 and 29 CFR 1926), including any consensus standards incorporated therein by reference.

\subsubsection{Preventive Maintenance}

a. The CVDF is a temporary facility. The scheduled duration for processing all of the $\mathrm{K}$ Basins SNF is 2 years. The design life of the equipment to operate the process shall be a minimum of 5 years to allow completion of the mission without regularly scheduled facility shutdowns for maintenance. The design of equipment shall incorporate the objective of efficient maintainability. The surveillance, testing, and maintenance of a system and its restoration to operational effectiveness shall be achieved at minimum costs with a minimum level of support services

(DOE Order 6430.1A, Section 1300-12.4.10).

b. The design shall consider the use of indicators, sensors, or alarms where practical to aid in the determination of the preventative maintenance schedule.

c. The maintenance design features, including replacement of valves and piping connected to the primary confinement barrier, shall be designed into the system so that these activities can be carried out under adequate HVAC inflow or isolation.

d. The design shall locate equipment and components outside of potentially contaminated areas wherever practical to reduce direct contact with contaminated surfaces and to minimize maintenance situations requiring the breach of normal containment.

e. To the maximum extent possible the design shall enhance the isolation capabilities of major components and energy sources in order to simplify lock and tag requirements.

\subsubsection{Modularity}

a. All systems requiring timely repair and/or special skills (e.g., electronic devices) shall be designed in a modular fashion to permit them to be easily changed out and repaired in maintenance areas. Modular design shall be employed whenever practical to reduce problems associated with removal and repair to a minimum.

b. To the maximum extent practical, standard commercially available components, systems, and parts shall be used.

c. The design shall minimize the initial cost, maintenance time and costs, training of operators and technicians, and spare parts inventory through the use of designs that 
permit large orders of common parts, designs that use commercially available units, and designs that minimize the total number of unique sizes.

\subsubsection{Special Maintenance Equipment}

a. Maintenance aids shall be installed as required to assist in removal and replacement of equipment, components, and skids.

b. Separate maintenance areas and/or workstations shall be set up to handle routine repairs.

\subsubsection{Calibration and Testing}

The design shall evaluate options for calibration and testing of equipment to reduce operating and maintenance costs, exposure to hazardous material, spare parts inventories (including safety related spares) and downtime. The following general guidelines shall be followed.

a. Where practical, calibration and test connections shall be provided to enable the device to be checked without removing the unit from service.

b. All units shall be provided with readily visible indication of failure where practical.

c. All remote reading equipment (i.e., valves, pressure and temperature sensors) shall have local readout indication on the equipment.

d. Modular replacement philosophy shall be employed.

e. Standard "off-the-shelf" instrumentation and components shall be used if available for the service required.

f. Automatic "on-line" calibration shall be specified where off-the-shelf units are available that meet the service required.

g. All components and/or modules shall be reviewed to minimize problems with decontamination (e.g., sealed units, hard smooth surfaces, positive pressure interiors in equipment cabinets with HEPA-filtered air intakes).

h. Test and calibration standards shall be traceable to National Institute of Standards and Technology. 


\subsubsection{Components and Spare Parts List}

a. As part of the operations and maintenance planning program effort, equipment, valve, piping, instrument, enclosure, component and spare parts lists shall be prepared.

b. The numbering and identification nomenclature shall be compatible with those currently used at $\mathrm{K}$ Basin.

c. Design reviews of the systems and equipment by operations staff shall be held. Safetyrelated spares shall be identified during these reviews.

\subsection{TEST REQUIREMENTS}

\subsubsection{Test and Inspection Requirements Plans}

a. Operational test and construction or fabrication inspection requirements plans shall be developed as part of the design to assure that compliance with the design drawings, specifications, and project criteria are met.

b. The testing shall be developed and phased to detect deficiencies at the earliest possible time to minimize project cost and schedule impacts. The minimum tests and quantifiable acceptance criteria necessary to demonstrate compliance with the design requirements shall be specified.

\subsubsection{Integrated Systems Test Plans}

Special plans shall be developed to manage the testing of the CVDF construction and government furnished systems. (See DOE Order 4700.1 and HNF-SD-SNF-SUP-003). These test plans shall include four phases.

a. The first phase shall be factory acceptance testing of shop fabricated items and shall include vendor shop inspections during procurement and fabrication, receiving inspections, reinstallation checkouts and operational tests.

b. The second phase is the construction acceptance testing for SSC of the CVDF before preoperational testing. This phase is primarily component testings.

c. The third phase is the preoperational acceptance testing for SSC of the CVDF before final operational testing. This phase is primarily system and subsystem testing.

d. The final phase is the operational test during dry-run testing. This will test the operator performance and the effectiveness of the procedures. 


\subsubsection{Spent Nuclear Fuel Project Process Validation Requirements}

A process validation requirements document, $\mathrm{HNF}-\mathrm{SD}-\mathrm{SNF}-\mathrm{CN}-027$, has been written to define an initial fuel processing plan which identifies unique measurements and special observations to be made during the validation period, and provide data to support and develop process control requirements for the balance of fuel processing operation. The CVDF design and operation shall support the implementation of the process validation requirements for CVDF.

\subsection{EQUIPMENT TURNOVER}

\subsubsection{Equipment Packages}

There shall be at least one turnover package for each plant system. If a system is large and can be divided into subsystems, partial system turnover packages are acceptable. Each package should contain the following elements:

a. Items common to every package

- Cover sheet with package and/or system number and construction release signatures

- Index and table of contents

- Outstanding work and equipment deficiency list

- System or component identity (listing and/or marked drawings showing exactly what is being turned over to Startup)

b. Items that should be included in the package, when applicable

- Control valve operator test record

- Instrument calibration and installation record

- Loop calibration result record (5 data points)

- Equipment installation and/or alignment record

- Motor-operated valve test record

- Electrical protective equipment test data

- Motor test record (include baseline vibration data $>1 \mathrm{hp}$

- Megger test record

- Motor control center breaker test report

- Motor overload relay test report

- $480 \mathrm{~V}$ circuit breaker test report

- Switchgear breaker test report 
- Flush/hydro/ISLT test report

- HVAC duct and housing leak test report

- HVAC system TAB report

- Electrical scheme verification (highlight drawings)

- $13.8 \mathrm{kV} / 480 \mathrm{~V}$ transformer test report

- Factory acceptance test report

- Crane load test reports

- HEPA filter aerosol (DOP) test report (when applicable)

- Tank cleanliness verification report

- HVAC damper stroke report

- Outstanding temporary modifications list

- Outstanding safety tagouts list

- Spare parts list

- Applicable vendor operation and maintenance manuals.

\subsection{DECONTAMINATION AND DECOMMISSIONING}

\subsubsection{Decontamination and Decommissioning Compliance Plans}

Decontamination and decommissioning plans for the CVDF shall be developed as required by DOE 6430.1A, Section 1300-11. The plan shall include considerations to be incorporated in the design, an analysis of the decommissioning activities, and a baseline decommissioning cost estimate.

\subsection{REFERENCES}

29 CFR 1910, "Occupational Safety and Health Standards," Code of Federal Regulations, as amended.

29 CFR 1926, "Regulations Relating to Labor," Code of Federal Regulations, as amended.

DOE Order 4700.1, 1987, Project Management System, U.S. Department of Energy, Washington, D.C.

DOE Order 5820.2A, 1988, Radioactive Waste Management, U.S. Department of Energy, Washington, D.C.

DOE Order 6430.1A, 1989, General Design Criteria, U.S. Department of Energy, Washington, D.C.

HNF-SD-SNF-CN-027, 1997, SNF Process Validation Requirements, Rev. 0, Draft, Fluor Daniel Hanford, Incorporated, Richland, Washington. 
HNF-SD-SNF-SUP-003, 1997, SNF Startup Plan, Rev. 0, Draft, Fluor Daniel Hanford, Incorporated, Richland, Washington.

ICRP Publication 37, 1982, Cost-Benefit Analysis in Optimization of Radiation Protection, International Commission on Radiological Protection, Elmsford, New York.

ICRP Publication 55, 1990, Optimization and Decision Making in Radiological Protection, International Commission on Radiological Protection, Elmsford, New York.

MIL-STD-1472E, 1996, Human Engineering Design Criteria for Military Systems, Equipment and Facilities, U.S. Department of Defense, Washington, D.C.

NUREG CR-3331, 1983, Methodology for Allocating Nuclear Power Plant Control Functions to Human or Automatic Control, U.S. Nuclear Regulatory Commission, Washington, D.C.

UCRL-15673, 1985, Human Factors Design Guidelines for Maintainability of Department of Energy Nuclear Facilities, U.S. Nuclear Regulatory Commission, Washington, D.C. 


\section{HNF-SD-SNF-DRD-002 REV I}

This page intentionally left blank. 
HNF-SD-SNF-DRD-002 REV 1

APPENDIX A

REQUIREMENTS FROM THE CODE OF FEDERAL REGULATIONS

AND U.S. DEPARTMENT OF ENERGY ORDERS 
HNF-SD-SNF-DRD-002 REV 1

This page intentionally left blank. 


\section{APPENDIX A \\ REQUIREMENTS FROM THE CODE OF FEDERAL REGULATIONS AND U.S. DEPARTMENT OF ENERGY ORDERS}

\section{CODE OF FEDERAL REGULATIONS}

- 10 CFR 20, "Standards for Protection Against Radiation"

10 CFR 20, "Standards for Protection Against Radiation," establishes standards for individual protection from ionizing radiation resulting from activities conducted under licenses issued by the U.S. Nuclear Regulatory Commission (NRC). These regulations quantify the permissible radiation doses to various body parts of an individual. The prescribed dose limits do not apply to doses due to background radiation and radiation received as part of a medical therapy or due to voluntary participation in medical research programs.

This regulation does not have direct impact on the Cold Vacuum Drying Facility (CVDF) design. However, this regulation will be maintained for reference as dose rates may have to be considered in the design process.

- 10 CFR 71, "Packaging and Transportation of Radioactive Material"

10 CFR 71, "Packaging and Transportation of Radioactive Material," is also an NRC Regulation that establishes requirements for packaging, preparation for shipment, and transportation of licensed material. This regulation also describes procedures and standards for NRC approval of packaging and shipping procedures for fissile material. The packaging and shipping aspects are also subject to other NRC regulations and requirements of other agencies, such as the Department of Transportation.

This regulation does not have direct bearing on the CVDF design. However, these regulations may have to be consulted to verify that the CVDF design poses no problems for packaging and transportation.

- 10 CFR 835, "Occupational Radiation Protection"

10 CFR 835, "Occupational Radiation Protection," is a U.S. Department of Energy (DOE) regulation that is very similar to 10 CFR 20.10 CFR 835 promulgates radiation protection standards, limits, and program requirements for protecting individuals from ionizing radiation resulting from the conduct of $\mathrm{DOE}$ activities. Activities conducted under NRC license are not covered by this regulation. Like 10 CFR 20, this requirement is also considered a reference requirement. 
- 29 CFR 1910, "Occupational Safety and Health Standards"

29 CFR 1910, "Occupational Safety and Health Standards," is promulgated by the Occupational Safety and Health Administration (OSHA) of the U.S. Department of Labor. The intent of this directive is to carry out OSHA requirements that have been found to be national consensus standards or established standards.

All routine industrial operations are covered under this requirement, from a simple administrative function such as maintaining worker exposure and medical surveillance records to complex operations such as handling hazardous materials. Minimum environmental controls required for a work area, provisions of proper personal protective equipment, fire protection requirements, noise control, and providing medical and first aid during emergencies also are covered under this requirement. These regulations may be exempt if it is determined that these standards do not improve health and safety for specially designated employees. These is no direct impact of these regulations on the CVDF design, but the design may have to be accomplished such that usage of the CVDF adheres to 29 CFR 1910. Hence, this regulation is maintained for reference.

\section{U.S. DEPARTMENT OF ENERGY ORDERS AND STANDARDS}

Table A-1 contains a list of DOE orders and DOE technical standards that contain provisions that will affect features of the design of the CVDF or that may affect the contents of the engineering and design documentation of the CVDF. A brief description of each of the entries follows.

- DOE 1300.2A, Department of Energy Technical Standards Programs

This DOE order sets forth policies and responsibilities for development and application of technical standards under DOE-controlled programs. This order stipulates that any applicable nongovernment standards (NGSs) must be used and the usage must be properly documented. This order also states that all DOE facilities, programs, and projects will use NGSs in their design, construction, testing, modification, operation, decommissioning, decontamination, and remediation when such standards are adequate. If the existing federal standards are more conservative than NGSs, DOE requirements will be used. Uses of all standards in the design have to be properly documented. This DOE order is a general guideline for using the technical standards. This document is kept on the reference list.

- DOE 1540.2, Hazardous Material Packaging for Transport - Administrative Procedures

This order establishes administrative procedures for the certification and use of packaging methods for radioactive and hazardous materials. The administrative 
procedures also summarize the actions associated with the review and approval of packaging for the transportation of radioactive and hazardous materials. This order details the review and approval procedure that provides a basis for DOE to assure the U.S. Department of Transportation, NRC, and other agencies that regulations are compiled with and the entire process is relevant to that of NRC. This DOE order has no direct impact on the CVDF design. As the packaging process has very little effect on the CVDF design, it is unlikely that this order will be used during the design process. However, DOE 1540.2 is retained for reference.

- DOE 1540.3A, Base Technology for Radioactive Material Transportation Packaging Systems

DOE 1540.3A is a culmination of DOE Orders 1330.1D, 1540.1A, 15402, and 5480.3; 10 CFR 71 and 49 CFR 171 through 179; the Atomic Energy Act; and the Department of Energy Organization Act of 1977. This order establishes DOE policies and responsibilities for coordinating and planning base technology for radioactive material transportation packaging systems. Radioactive material is defined as any material having a specific activity greater than 0.002 microcuries per gram. This DOE order is more of an administrative document than a design document. Consequently, this order will have very little impact on either the CVDF design or the design process. However, this document is maintained for reference purposes.

- DOE 5480.4, Environmental Protection, Safety, and Health

This DOE order lists requirements for the application of the mandatory environmental protection, safety, and health (ES\&H) standards applicable to all DOE operations. This order must be followed during design, construction, modification, and decommissioning. All permanent and temporary facilities must comply with this order. The requirements listed in this DOE order are divided into the following three categories:

1. Mandatory ES\&H Standards (Statutory Requirements)

Those standards that are mandatory as a result of non-DOE federal or state statutes are addressed in this category. None of these standards are applicable to CVDF design.

\section{Mandatory ES\&H Standards (Policy Requirements)}

Standards that are mandatory because of DOE policies are listed under this category. Subsection $\mathrm{F}$, which addresses nuclear safety, may be used for guidance for CVDF design. However, these standards are mainly oriented toward nuclear reactors. 


\section{Reference ES\&H Standards}

Those standards that are not mandatory but are useful to refer to as good practice and for general ES\&H purposes. None are directly applicable for CVDF design.

This DOE order does not appear to have any direct impact on the CVDF design. However, this document will be retained as reference.

\section{- DOE 5400.1, General Environmental Protection Program}

This order states that environmental notification and reporting requirements are to be determined on a case-by-case facility basis. It requires an annual environmental report that is essentially an emissions summary. It requires that an environmental protection plan and an environmental monitoring plan be developed and approved. These should be approved before authorization to initiate operations is given. The CVDF design will have to include appropriate monitoring capability.

- DOE 5400.3, Hazardous and Radioactive Mixed Waste Program

This order implements Resource Conservation and Recovery Act regulations in the DOE. The CVDF will generate radioactive waste that is regulated by the Resource Conservation and Recovery Act.

\section{- DOE 5400.4, CERCLA Requirements}

This order implements Comprehensive Environmental Response, Compensation, and Liability Act regulations in the DOE.

- DOE 5400.5, Radiation Protection of the Public and the Environment

This order sets limits on public doses from normal operations, defines derived air concentrations, and implements International Commission on Radiation Protection recommendations.

- DOE 5440.1E, NEPA Compliance Program

This order implements the National Environmental Protection Act in the DOE.5480.1B Environment, Safety, and Health Program. This document is the master document for the 5480 -series of orders.

- DOE 5480.4, Environmental Protection, Safety, and Health Protection Standards

This order implements a list of regulations that apply to private organizations but that are not automatically applied to the DOE. The order is a useful reference list. 
This notice sets policy regarding radiation exposure limits, radiation area practices, and as-low-as-reasonably-achievable (ALARA) considerations. A design program is required to achieve the ALARA goal. The guideline also contains criteria governing the design of change rooms and other radiation or radioactive material control procedures. One key criterion is the ALARA design guideline of $500 \mathrm{mrem} / \mathrm{yr}$ for an individual radiation exposure.

- DOE 5480.7A, Fire Protection

This order relates to nuclear facility safety issues such as fire protection of safety-class equipment, fire hazards analysis for the design basis fire to be included in the safety analysis report, seismic criteria for the fire protection system, and life safety codes. It sets forth provisions that address loss limitation for government-owned facilities.

\section{- DOE 5480.9, Construction Safety and Health Program}

This order implements requirements found in the OSHA regulations regarding construction safety. Construction specifications should reference appropriate requirements.

- DOE 5480.19, Conduct of Operations Requirements for DOE Facilities

Safety of workers and protection of the public requires that nuclear facilities be formally managed by an operations program that meets high standards of discipline. In the NRC nuclear power arena, the conduct of operations requirements are specified by the International Commission on Radiation Protection. This order implements similar requirements for facilities regulated by the DOE. It addresses operations procedures, shift changes, operator training, and so forth. The design team will write a draft Conduct of Operations Plan.

- DOE 5480.21, Unresolved Safety Questions

This order is analogous to 10 CFR 50.59. It establishes a process for changing the operating basis of the facility and allows the operator the freedom to perform experiments and investigate safety issues that may arise while conducting day-to-day operations.

\section{- DOE 5480.22, Technical Safety Requirements}

This order requires that safety limits for the operating parameters of the facility be established, that procedures for ensuring that these limits are not exceeded be established, that these parameters be monitored; and that response actions for conditions outside the safety limits be determined. 
- DOE 5480.23, Nuclear Safety Analysis Reports

This order applies in its entirety because it is the document that defines the requirements for safety analysis and safety analysis reports, which are the means of demonstrating that the public, environment, and workers are adequately protected. This order has the following major impacts on the project.

- A preliminary hazards analysis is to be performed and published. Guidance is given by DOE-STD-1027-92.

- A Preliminary Safety Analysis Report (PSAR) is to be developed. The PSAR is developed simultaneously with design. There is iteration between safety analysis and design. The PSAR analysis demonstrates that the design adequately mitigates the consequences of the hazards presented in the hazards analysis. The PSAR normally must be reviewed by DOE and approved before procurement and construction is initiated (generally accepted practice according to DOE Order 4700.1, but not required by DOE Order 5480.23 ). The requirement for approval before initiation of procurement and construction has been implemented to limit the federal government's financial risk and to ensure that the DOE does not have a conflict of interest in that those performing the review could be biased because the Department has a commitment requiring protection

- A Final Safety Analysis Report (FSAR) is to be developed. This report updates the PSAR to reflect the as-built facilities and incorporates the operating procedures for the facilities. Approval of the FSAR constitutes agreement that the nuclear facility safety issues have been properly addressed and is required to initiate operations.

- DOE 5480.28, Natural Phenomena Hazards Mitigation

This order establishes requirements for response of facilities to natural phenomena such as earthquakes and high winds.

- DOE 5480.31, Start-up and Restart of Nuclear Facilities

This order sets out requirements for authorization to initiate operations utilizing nuclear materials. Essentially this document establishes the DOE "licensing" criteria. The Operating Readiness Plan should be written by the design team. The plan should follow the guidance of DOE-STD-3006-95, Planning and Conduct of Operational Readiness Reviews.

- DOE 5483.1A, Occupational Safety and Health Program for DOE Contractor Employees at Government Owned Contractor Operated Facilities

This order implements OSHA within the DOE. 
- DOE 5700.6C, Quality Assurance

The document is analogous to ASME NQA-1, Quality Assurance Program Requirements for Nuclear Facilities, which is a nuclear facilities quality assurance guideline required by DOE Order 6430.1A.

- DOE 5820.2A, Radioactive Waste Management

This order requires a waste management plan, has decontamination and decommissioning requirements, and sets waste characterization standards, as well as establishing numerous other requirements that affect both the design and operation of the CVDF.

\section{- DOE 6430.1A, General Design Criteria}

This DOE order provides general design criteria (GDC) for various engineering disciplines. The GDC are mandatory for all DOE-related work and provide minimal . acceptable design requirements for DOE facilities. Although DOE facilities are not mandated to follow state, county, and other requirements, it is recommended that they interface with the non-DOE authorities to accommodate their intent as much as possible. The GDC contains 16 numerical divisions devoted to major building systems or design specialties. According to DOE instructions, the GDC must be used in the planning, design, and development of specifications for facilities, including the development of site- and equipment-specific designs. See Table A-2 for a listing of the section of DOE Order 6430.1A that apply to the design of the CVDF. Provided the GDC is not adequate, supplemental standards may be used. ASME B31.3, Chemical Plant and Petroleum Refinery Piping, and the Industrial Vacuum Practices are considered to be supplemental standards that will be used for the CVDF design.

The following sections of the GDC are considered applicable to the CVDF design. The criteria evaluation document developed for the CVDF goes into the applicability of the GDC in more extensive detail.

\section{- Division 1, General Requirements}

Section 0111-99.0.1, "Non-Reactor Nuclear Facilities"

Paragraphs 1, 4, 5, and 6 on Page 1-97,

Paragraphs 2 and 3 on Page 1-98.

Section 0111-99.0.2, "Tornado of Extreme Wind"

Portions of this section are applicable.

Section 0111-99.0.4, "Earthquakes"

The entire section is applicable.

Section 0111-99.0.7, "Explosion, Internal Pressurization, Criticality, and Other DBA Causes"

Section 0140, "Quality Assurance" 
- $\quad$ Division 13, Special Facilities

Section 1300-1, "Coverage and Objectives"

Many sub-sections are applicable.

Section 1300-2, "Safety Analysis"

Section 1300-3.2, "Safety Class Items"

Most of this section's contents are applicable. This section also proposes the use of ASME Boiler and Pressure Vessel Codes wherever they are applicable.

Section 1300-3.3, "Single Failure Criterion and Redundancy"

Section 1300-3.4, "Equipment Environment Considerations"

Most of the requirements specified in the three subsections are applicable.

Section 1300-3.5, "Maintenance"

Second paragraph of this section is especially applicable.

Section 1300-3.6, "Testing"

Portions of first and second paragraphs are applicable.

Section 1300-4, "Nuclear Criticality Safety"

This section describes the procedures to assess as early as possible if the

potential for nuclear criticality exists. Several portions of this section may be applicable.

Section 1320, "Irradiated Fissile Material Storage Facilities"

This section describes irradiated fissile material storage facilities (ISMSF).

Portion of subsections $1320-1,-2$, and -3 are applicable.

A summary of the key criteria from the 1320 paragraphs is as follows.

Criticality safety shall be maintained by geometry control preferably.

Neutron absorbers may be used but there are restrictions.

To the extent possible passive cooling will be used in dry storage facilities.

Detection systems are to be included to detect accidental release of radioactive materials into the plant.

Shielding and radiation field monitoring instruments are to be provided to achieve ALARA radiation exposure conditions.

There shall be provision for temporary handling of leaking containers.

There shall be two levels of confinement. The can (multicanister overpack) shall be the primary confinement structure. The building shall be the secondary confinement structure. The can shall provide confinement during normal operating and anticipated operational occurrences. The building shall additionally function as a confinement barrier as necessary to perform its safety functions during design basis accidents including natural phenomena events. The necessary safety functions for the building 
are to be determined by safety analysis using the offsite release exposure analysis guidelines given in Section 1300-1.4.2.

Recirculation of the secondary confinement air is acceptable provided that it is filtered by high-efficiency particulate air (HIEPA) filters. (Note that this practice has been successfully implemented for 20 years in PF-4 at TA-55 of Los Alamos National Laboratory. This is the only operational plutonium processing facility in the DOE complex at this time).

The extent of exhaust filtration (e.g., number of HEPA filter stages, iodine absorbers) is to be determined by safety analysis considering the consequences of credible releases and the guidelines of Section 1300-1.4.2.

Provisions for handling solid and liquid waste are to be provided.

Exhausts shall be monitored for transuranic and fission product contaminants. The exhaust monitoring shall comply with the requirements of Section 1589-99.0.1.

Key confinement system ventilation requirements are referred to ERDA 76-21 and to the 1550-99 paragraphs of the order. The key statement comes from 1550-99.0.1, "General Ventilation and Off-Gas Criteria," which states, "These criteria cover ventilation and off-gas systems, or portions of them, that are identified as safety class items in accordance with Section 1300-3.2, Safety Class Items." Strictly speaking, this means that the CVDF will not be governed by these requirements. Nonetheless the principles stated in 1550-99.0.2, "Confinement Ventilation Systems," should be followed as a matter of good engineering practice (except where specific references to the safety-class characteristics of the system are made). The basic design concepts for exhaust filtration performance and stack design should be derived from safety analysis that analyzes the consequences of credible release scenarios.

Section 0110-12.8.1 requires that an energy conservation report should be written for new buildings over $10,000 \mathrm{ft}^{2}$. A waver from this requirement should be requested given that the facility's operating lifetime is only 2 years and the ventilation system recirculates the majority of the air in the building so that heat lost through exhaust has already been minimized.

Section 1300-12, "Human Factors Engineering," requires that a human factors program plan be written. The level of detail in the plan is to be determined by the complexity or safety issues associated with human activities. The subsections also set out extensive human factors requirements for human factors engineering. A plan should be writen and implemented for the CVDF given that the radiation exposure during operations can severely restrict the staff planning. 


\section{HNF-SD-SNF-DRD-002 REV 1}

- DOE-STD-0101-92, Compilation of Nuclear Safety Criteria For Potential Application to DOE Non-Reactor Nuclear Facilities

This standard contains a listing of references.

- DOE-STD-1020-94, Natural Phenomena Hazards Design and Evaluation Criteria for Department of Energy Facilities

This standard gives guidance regarding the selection of design criteria to be applied to the structural design of nuclear facilities.

- DOE-STD-1021-93, Natural Phenomena Hazards Performance Categorization Guidelines For Structures, Systems and Components

See discussion above.

- DOE-STD-1027-92, Hazard Categorization and Accident Analysis Techniques for Compliance With DOE Order 5480.23, Nuclear Safety Analysis Reports

See discussion above.

- DOE-STD-1044-93, Guide to Good Practices for Equipment and Pipe Labeling

This standard sets forth guidelines for labeling equipment and piping.

- DOE-STD-3003-94, Backup Power Sources for DOE Facilities

There is no safety requirement for backup power in the CVDF. The guidance in this guideline will be followed if backup power is included for other reasons.

- DOE-STD-3006-95, Planning and Conduct of Operational Readiness Reviews

Operational readiness review planning will be addressed by the design team in order to ensure that the necessary engineering documentation is ready for the operational readiness review.

- DOE-STD-3009-94, Preparation Guide for U.S. DOE Nonreactor Nuclear Facility Safety Analysis Reports

See discussion above.

- DOE-STD-3011-94, Guidance for Preparation of DOE 5480.22 (TSR) and DOE 5480.23 (SAR) Implementation Plans

These plans will be drafted as part of the design process. 


\section{HANFORD SITE DOCUMENTS}

- WHC-CM-4-2, Quality Assurance Manual

This manual describes the requirements that apply to Hanford Site divisions and departments that prescribe, perform, or verify activities affecting quality, including operations, decommissioning and decontamination, and environmental activities. This manual emphasizes that quality assurance controls must be applied to any items and activities performed under Hanford Site contractor management. The manual consists of 19 sections with each section dedicated to a certain aspect of quality control. This is a compulsory requirement for each operation involved in the transfer of spent nuclear fuel from $\mathrm{K}$ Basins. Requirements of this manual, in conjunction with $10 \mathrm{CFR}$ Part 830.120 , should provide more than adequate quality control.

- WHC-CM-6-1, Standard Engineering Practices

This manual establishes the engineering practices that ensure that uniform methods are in place for performing all tasks under Hanford Site contractor control. These procedures provide methodologies for tasks such as design review, configuration management, change control, specification preparation, and review and approval requirements. The use of this document is strongly recommended on all engineering, development, and project tasks that culminate in a document design and/or deliverable hardware end items. Of several sections in this manual, Section 4 on design verification requirements is the most applicable for CVDF design. This section provides methods and procedures governing design verification measures to verify the design adequacy. This requirement and DOE Order $6430.1 \mathrm{~A}$ provide comprehensive guidelines for the design task.

\section{- WHC-CM-2-14, Hazardous Material Packaging and Shipping}

This manual describes requirements and procedures for packaging and shipping hazardous wastes both onsite and offsite. This manual has been prepared by the Hanford Site based on several CFRs, DOE Orders, WACs, and other pertinent documents including controlled manuals. In addition to other requirements, instructions of this requirement have to be followed only when the spent nuclear fuel is categorized as hazardous material. This requirement has no direct impact on the CVDF design. This document is maintained for reference.

\section{- WHC-CM-3-5, Document Control and Records Management Manual}

This manual was developed to provide requirements and procedures for maintaining the information that is produced for any project. The information could be in such form as paper, punched cards, magnetic tapes, or computer disks. The main objective of this program is to preserve records that may be useful and of future value in a proper manner. There is no impact of this requirement on the CVDF design. 
However, all the paper work and computer formatted data will be transferred to the Hanford Site Spent Nuclear Fuel Project for upkeeping of the records. This manual is retained for reference purposes only.

- Fiscal Year 1995, Hanford Mission Plan, Volume 1, Site Guidance, September 1994

The Hanford Mission is to cleanup the site, develop new technologies, and to help the economic diversification of the region. The transfer of $\mathrm{K}$ Basin fuel is a part of the cleanup mission. This document has no impact on either CVDF design or the design process. However, this document is the basic report in which all Hanford cleanup programs are described. This document is maintained on the reference list. 


\section{HNF-SD-SNF-DRD-002 REV 1}

Table A-1. U.S. Department of Energy Orders Summary.

\begin{tabular}{|c|c|}
\hline $\begin{array}{l}\text { Order/ } \\
\text { standard }\end{array}$ & Title \\
\hline 5400.3 & Hazardous and Radioactive Mixed Waste Program \\
\hline 5400.4 & Comprehensive Environmental Response, Compensation, and Liability Act Requirements \\
\hline 5400.1 & General Environmental Protection Program \\
\hline 5400.5 & Radiation Protection of the Public and the Environment \\
\hline $5440.1 \mathrm{E}$ & National Environmental Policy Act Compliance Program \\
\hline $5480.1 \mathrm{~B}$ & Environment, Safety, and Health Program \\
\hline 5480.4 & Environmental Protection, Safety and Health Protection Standards \\
\hline N5480.6 & DOE RadCon Manual \\
\hline $5480.7 \mathrm{~A}$ & Fire Protection \\
\hline 5480.9 & Construction Safety and Health Program \\
\hline 5480.19 & Conduct of Operations Requirements for DOE Facilities \\
\hline 5480.21 & Unreviewed Safety Questions \\
\hline 5480.22 & Technical Safety Requirements \\
\hline 5480.23 & Nuclear Safety Analysis Reports \\
\hline 5480.28 & Natural Phenomena Hazards Mitigation \\
\hline 5481.31 & Start-Up and Restart of Nuclear Facilities \\
\hline $5483.1 \mathrm{~A}$ & $\begin{array}{l}\text { Occupational Safety and Health Program for DOE Contractor Employees at Government-Owned } \\
\text { Contractor-Operated Facilities }\end{array}$ \\
\hline $5700.6 \mathrm{C}$ & Quality Assurance \\
\hline $5820.2 \mathrm{~A}$ & Radioactive Waste Management \\
\hline $6430.1 \mathrm{~A}$ & General Design Criteria \\
\hline STD-0101 & $\begin{array}{l}\text { Compilation of Nuclear Safety Criteria for Potential Application to DOE Non-Reactor Nuclear } \\
\text { Facilities }\end{array}$ \\
\hline STD-1020 & Natural Phenomena Hazards Design and Evaluation Criteria for DOE Facilities \\
\hline STD-1021 & $\begin{array}{l}\text { Natural Phenomena Hazards Performance Categorization Guidelines for Structures, Systems, and } \\
\text { Components }\end{array}$ \\
\hline STD-1027 & $\begin{array}{l}\text { Guidance For Preliminary Hazard Classification and Accident Analysis Techniques for Compliance } \\
\text { With DOE Order } 5480.23 \text {, Safety Analysis Reports }\end{array}$ \\
\hline STD-1044 & Guide To Good Practices for Equipment and Piping Labeling \\
\hline STD-3003 & Backup Power Sources for DOE Facilities \\
\hline STD-3006 & Planning and Conduct of Operations Readiness Reviews \\
\hline STD-3009 & Preparation Guide for U.S. DOE Nonreactor Nuclear Facility Safety Analysis Reports \\
\hline STD-3011 & Guidance for Preparation of DOE 5480.22 (TSR) and DOE 5480.23 (SAR) Implementation Plans \\
\hline
\end{tabular}




\section{HNF-SD-SNF-DRD-002 REV 1}

Table A-2. Screening of Process and Facility Design, Safety or Safety Analysis Report Required Applicable Sections of DOE Order 6430.1A for Chapters 2.0 and 3.0 of the Design Requirements Document. (10 sheets)

\begin{tabular}{|c|c|c|c|}
\hline Section no. & Title & Applicable & Justification \\
\hline Division 1 & General Requirements & A & Design and SAR requirements \\
\hline $1-0101$ & Criteria Purpose and Application & NA & Information Only \\
\hline $1-0106$ & Regulatory Requirements & NA & Reference Only \\
\hline $1-0109$ & Reference Standards and Guides & NA & Reference Only \\
\hline $1-0110$ & $\begin{array}{l}\text { Architectural and Special Design } \\
\text { Requirements }\end{array}$ & A & SAR requirements \\
\hline-1 & $\begin{array}{l}\text { Design, Programmatic, and Operating } \\
\text { Requirements }\end{array}$ & A & $\begin{array}{l}\text { Emergency planning, Sec. 1.3, required by } \\
\text { SAR }\end{array}$ \\
\hline-1.3 & Emergency Planning & A & SAR requirement \\
\hline-2 & Alternative Designs & NA & Not required by SAR \\
\hline-3 & Flexibility & NA & Not required by $S A R$ \\
\hline-4 & Operational Efficiency & NA & Not required by SAR \\
\hline-5 & Health and Safety & A & SAR requirement \\
\hline-6 & Fire Protection & A & SAR requirement \\
\hline-7 & $\begin{array}{l}\text { Environmental Protection and Pollution } \\
\text { Control }\end{array}$ & A & SAR requirement \\
\hline-8 & $\begin{array}{l}\text { Accommodations for the Physically } \\
\text { Handicapped }\end{array}$ & NA. & Not required by SAR \\
\hline-9 & $\begin{array}{l}\text { Operation, Maintenance, Repair, and } \\
\text { Replacement }\end{array}$ & A & SAR requirement \\
\hline-10 & Fallout Sheiters & NA. & None in design \\
\hline-11 & Work Space Management Standards & NA & Not required by SAR \\
\hline-12 & Energy Conservation & NA & Not required by SAR \\
\hline-13 & Physical Protection & NA & $\begin{array}{l}\text { Not required by SAR (Part of Security } \\
\text { Plan) }\end{array}$ \\
\hline-99 & Special Facilities & A & $\begin{array}{l}\text { Facility is classified as a special facility } \\
\text { because of radioactive contents }\end{array}$ \\
\hline-99.0 & Nonreactor Nuclear Facilities & A & $\begin{array}{l}\text { Classified as a Nonreactor Nuclear } \\
\text { Facility }\end{array}$ \\
\hline-99.0 .1 & General & A & SAR requirement \\
\hline-99.0 .2 & Building Services and Distribution & A & SAR requirement \\
\hline-99.0 .3 & Utilization Schedule & NA & Not required by SAR \\
\hline-99.0 .4 & Building Layout & A & SAR requirement \\
\hline-99.0 .5 & Interior Walls and Partitions & NA & Not required by SAR \\
\hline-99.0 .6 & Fire Resistance & A & SAR requirement \\
\hline
\end{tabular}


Table A-2. Screening of Process and Facility Design, Safety or Safety Analysis Report Required Applicable Sections of DOE Order 6430.1A for Chapters 2.0 and 3.0 of the Design Requirements Document. (10 sheets)

\begin{tabular}{|c|c|c|c|}
\hline Section no. & Title & Applicable & Justification \\
\hline-99.0 .7 & Loss Limitations & A & SAR requirement \\
\hline-99.0 .8 & Personnel and Public Safety & A & SAR requirement \\
\hline $1-0111$ & Structural Design Requirements & A & SAR requirement \\
\hline-1 & General & NA & Information only \\
\hline-2 & Loads & A & SAR requirement \\
\hline-3 & $\begin{array}{l}\text { Structural Systems for Buildings and } \\
\text { Other Structures }\end{array}$ & NA & Not required by SAR \\
\hline-4 & $\begin{array}{l}\text { Structural Systems for Highway and } \\
\text { Railway Structures }\end{array}$ & NA & None in design \\
\hline-99 & Special Facilities & A & Classified as a Special Facility \\
\hline-99.0 & Nonreactor Nuclear Facilities - General & A & $\begin{array}{l}\text { Classified as a Nonreactor Nuclear } \\
\text { Facility }\end{array}$ \\
\hline $1-0140$ & Quality Assurance & A & SAR requirement \\
\hline $1-0150$ & $\begin{array}{l}\text { Construction Facilities and Temporary } \\
\text { Controls }\end{array}$ & NA & Not required by $\mathrm{SAR}$ \\
\hline $1-0170$ & Construction Contract Closeout & NA & Not required by $\mathrm{SAR}$ \\
\hline Division 2 & Site and Civil Engineering & A & SAR requirements \\
\hline $2-0200$ & Site Development & A & SAR requirements \\
\hline-1 & Facility Siting & $\mathrm{A}$ & SAR requirement \\
\hline-2 & Building Location & A & SAR requirement \\
\hline-99 & Special Facilities & A & Classified as a Special Facility \\
\hline-99.0 & Nonreactor Nuclear Facilities - General & A. & $\begin{array}{l}\text { Classified as a Nonreactor Nuclear } \\
\text { Facility }\end{array}$ \\
\hline $2-0201$ & Subsurface Investigations & A & $\begin{array}{l}\text { Foundation seismic design, } \\
\text { Sec. 2-0201-4, required by SAR }\end{array}$ \\
\hline-4 & $\begin{array}{l}\text { Foundation Engineering Evaluation and } \\
\text { Recommendations }\end{array}$ & A & $\begin{array}{l}\text { SAR requirement for seismic foundation } \\
\text { design }\end{array}$ \\
\hline $2-0202$ & Surveying & $\mathrm{NA}$ & Not required by SAR \\
\hline $2-0203$ & Utilities Within Easements or Corridors & NA & Not required by $\mathrm{SAR}$ \\
\hline $2-0205$ & $\begin{array}{l}\text { Demolition, Decontamination, and } \\
\text { Decommissioning }\end{array}$ & A & SAR requirement \\
\hline-1 & Demolition & NA & Not required by $\mathrm{SAR}$ \\
\hline-2 & Decontamination and Decommissioning & A & SAR requirement \\
\hline $2-0210$ & Site Preparation & NA & Not required by $S A R$ \\
\hline $2-0214$ & Dewatering & $\mathrm{NA}$ & Not required by SAR \\
\hline
\end{tabular}




\section{HNF-SD-SNF-DRD-002 REV 1}

Table A-2. Screening of Process and Facility Design, Safety or Safety Analysis Report Required Applicable Sections of DOE Order 6430.1A for Chapters 2.0 and 3.0 of the Design Requirements Document. (10 sheets)

\begin{tabular}{|c|c|c|c|}
\hline Section no. & Title & Applicable & Justification \\
\hline $2-0215$ & Shoring and Underpinning & NA & Not required by SAR \\
\hline $2-0220$ & Earthwork & NA & Covered in Sec. 2-0201-4 \\
\hline $2-0235$ & Building Foundations & NA & Covered in Sec. 2-0201-4 \\
\hline $2-0245$ & Railroad Design & NA & None in design \\
\hline $2-0250$ & Paving and surfacing & NA & Not required by $\mathrm{SAR}$ \\
\hline $2-0256$ & Airports and Heliports & NA & None in design \\
\hline $2-0260$ & Piped Utility Materials & A & Sec. 2-0260-2 required by SAR \\
\hline-2 & Exterior Utilities & A & SAR requirement \\
\hline $2-0262$ & Corrosion Control & NA & Covered in Sec. $2-0260-2$ \\
\hline $2-0266$ & Water Distribution Systems & A & SAR requirement \\
\hline-1 & General & NA & Reference Only \\
\hline-2 & Regulatory Overview & A & SAR requirement \\
\hline-3 & Planning for Water Distribution Systems & A & SAR requirement \\
\hline-4 & System Design Considerations & A & SAR requirement \\
\hline $2-0267$ & Industrial Water Treatment & NA & None in design \\
\hline $2-0270$ & $\begin{array}{l}\text { Sanitary Wastewater Collection and } \\
\text { Stormwater Management Systems }\end{array}$ & A & SAR requirement \\
\hline-1 & Sanitary Wastewater Collection Systems & A & SAR requirement for Sec. -1.3 only \\
\hline-2 & Stormwater Management Systems & A & SAR requirement for Flooding Analysis \\
\hline $2-0273$ & Water Pollution Controls & A & SAR requirement \\
\hline-1 & General & & \\
\hline.-2 & Regulatory Overview & NA & Reference Only \\
\hline-3 & $\begin{array}{l}\text { Planning for Sanitary Wastewater } \\
\text { Treatment and Disposal Systems }\end{array}$ & A & SAR requirement \\
\hline-4 & $\begin{array}{l}\text { Selection of Sanitary Wastewater } \\
\text { Treatment and Disposal Methods }\end{array}$ & A & SAR requirement \\
\hline-99 & Special Facilities & A & Classified as a Special Facility \\
\hline-99.0 & Nonreactor Nuclear Facilities - General & A & $\begin{array}{l}\text { Classified as a Norreactor Nuclear } \\
\text { Facility }\end{array}$ \\
\hline $2-0275$ & Industrial Wastewater Treatment & NA & None in design \\
\hline $2-0276$ & $\begin{array}{l}\text { Construction in Floodplains or on } \\
\text { Wetlands }\end{array}$ & NA & Not required by $\mathrm{SAR}$ \\
\hline $2-0278$ & Power and Lighting & NA & Covered in Sec. 1600 \\
\hline $2-0279$ & $\begin{array}{l}\text { Exterior Communications and Alarm } \\
\text { Systems }\end{array}$ & A & Fire alarm systems only $S A R$ requirement \\
\hline
\end{tabular}


Table A-2. Screening of Process and Facility Design, Safety or Safety Analysis Report Required Applicable Sections of DOE Order 6430.1A for Chapters 2.0 and 3.0 of the Design Requirements Document. (10 sheets)

\begin{tabular}{|c|c|c|c|}
\hline Section no. & Title & Applicable & Justification \\
\hline $2-0280$ & Site Improvements & NA & Not required by $\mathrm{SAR}$ \\
\hline $2-0281$ & Vehicular and Pedestrian Circulation & A & SAR requirement for emergency vehicles \\
\hline-1 & General & A & $\begin{array}{l}\text { Emergency vehicle access SAR } \\
\text { requirement }\end{array}$ \\
\hline-3 & Vehicle Circulation Facilities & A & $\begin{array}{l}\text { Emergency vehicle access } \mathrm{SAR} \\
\text { requirement }\end{array}$ \\
\hline $2+0283$ & Physical Protection & NA & Not required by SAR \\
\hline $2-0285$ & Solid Waste Systems & NA & None in design \\
\hline $2-0290$ & Landscaping & NA & Not required by SAR \\
\hline $2-0291$ & Irrigation Systems & NA & None in design \\
\hline Division 3 & Concrete & NA & Not required by SAR \\
\hline Division 4 & Masonry & NA & Not required by $S A R$ \\
\hline Division 5 & Metals & NA & Covered in Sec. 1-0111 \\
\hline Division 6 & Wood and Plastics & NA & Not required by SAR \\
\hline Division 7 & Thermal and Moisture Protection & A & Firestopping only SAR requirement \\
\hline $7-0727$ & Firestopping & $\mathrm{A}$ & Firestopping SAR requirement \\
\hline Division 8 & Doors and Windows & A. & $\begin{array}{l}\text { Fire protection requirements for doors only } \\
\text { SAR requirement }\end{array}$ \\
\hline $8-0800-1$ & General, Doors & A & Fire protection SAR requirement \\
\hline Division 9 & Finishes & A. & $\begin{array}{l}\text { For fire protection, decontamination, and } \\
\text { suspended systems SAR requirements } \\
\text { only }\end{array}$ \\
\hline $9-0900-3$ & Hazardous Materials Contamination & A & For decontamination SAR requirements \\
\hline $9-0900-99$ & Special Facilities & A & Classified as a Special Facility \\
\hline-99.0 & Nonreactor Nuclear Facilities - General & A & For decontamination SAR requirements \\
\hline $9-0900-0910$ & Metal Support Systems & A & $\begin{array}{l}\text { For suspended systems seismic design } \\
\text { SAR requirements only }\end{array}$ \\
\hline-2 & Ceiling Suspension Systems & $\mathrm{A}$ & $\begin{array}{l}\text { For suspended systems seismic design } \\
\text { SAR requirements only }\end{array}$ \\
\hline Division 10 & Specialties & NA & None in design \\
\hline Division 11 & Equipment & A & SAR requirement for Process Hood only. \\
\hline $11-1161$ & Enclosures & A & SAR requirement for Process Hood only. \\
\hline-1 & General Considerations & NA & None in design \\
\hline-2 & Construction & NA & None in design \\
\hline-3 & Fire Protection & NA. & None in design \\
\hline
\end{tabular}


Table A-2. Screening of Process and Facility Design, Safety or Safety Analysis Report Required Applicable Sections of DOE Order 6430.1A for Chapters 2.0 and 3.0 of the Design Requirements Document. (10 sheets)

\begin{tabular}{|c|c|c|c|}
\hline Section no. & Title & Applicable & Justification \\
\hline-4 & Ventilation & A & Process Hood \\
\hline-5 & Operational Compatibility & A & Process Hood \\
\hline Division 12 & Furnishings & NA & Not required by SAR \\
\hline Division 13 & Special Facilities & A & Classified as a Special Facility \\
\hline $13-1300$ & General Requirements & A & Classified as a Special Facility \\
\hline-1 & Coverage and Objectives & A & $\begin{array}{l}\text { Design objectives requirements for Special } \\
\text { Facilities }\end{array}$ \\
\hline-1.3 & Objectives & A & Design objectives requirements \\
\hline-1.4 & $\begin{array}{l}\text { Guidance on Limiting Exposure of the } \\
\text { Public }\end{array}$ & A & SAR criteria requirement \\
\hline-2 & Safety Analysis & A & $\mathrm{SAR}$ required \\
\hline-3 & Safety Class Criteria & A & SAR requirement \\
\hline-4 & Nuclear Criticality Safety & A & SAR requirement. \\
\hline-5 & Source and Special Nuclear Material & $\mathrm{A}$ & Part of Security Plan \\
\hline-6 & Radiation Protection & A & SAR requirement \\
\hline-7 & Confinement Systems & A & SAR requirement \\
\hline-8 & Waste Management & A. & SAR requirement \\
\hline-9 & Effluent Control and Monitoring & A & SAR requirement \\
\hline-10 & $\begin{array}{l}\text { Physical Protection, Material Safeguards, } \\
\text { and Storage of Special Nuclear Material }\end{array}$ & A & Part of Security Plan. \\
\hline-11 & Decontamination and Decommissioning & A & SAR requirement \\
\hline-12 & Human Factors Engineering & A & SAR requirement \\
\hline-12.1 & Coverage & NA & Reference only \\
\hline-12.2 & Objectives & A & SAR requirement \\
\hline-12.3 & System Development & A & SAR requirement \\
\hline-12.4 & $\begin{array}{l}\text { General Human Factors Implementation } \\
\text { Criteria and Considerations }\end{array}$ & A & SAR requirement \\
\hline-13 & $\begin{array}{l}\text { Accessibility and Usability by the } \\
\text { Physically Handicapped }\end{array}$ & NA & $\begin{array}{l}\text { Hazardous area not generally open to the } \\
\text { physically handicapped. }\end{array}$ \\
\hline $13-1304$ & $\begin{array}{l}\text { Plutonium Processing and Handling } \\
\text { Facilities }\end{array}$ & A & $\begin{array}{l}\text { These requirements apply to the MCO } \\
\text { water drain piping and Process Water } \\
\text { Conditioning System only. }\end{array}$ \\
\hline-1 & Coverage & NA & Information only \\
\hline-2 & Objectives & $\mathrm{A}$ & Design objectives \\
\hline-3 & Nuclear Criticality Safety & A & SAR requirement \\
\hline
\end{tabular}


Table A-2. Screening of Process and Facility Design, Safety or Safety Analysis Report Required Applicable Sections of DOE Order 6430.1A for Chapters 2.0 and 3.0 of the Design Requirements Document. (10 sheets)

\begin{tabular}{|c|c|c|c|}
\hline Section no. & Title & Applicable & Justification \\
\hline-4 & Radiation Protection & A & SAR requirement \\
\hline-5 & Special Design Features & A & SAR requirement \\
\hline-6 & Confinement Systems & A & SAR requirement \\
\hline-7 & Effluent Control and Monitoring & A & SAR requirement \\
\hline-8 & Decontamination and Decommissioning & A & SAR requirement \\
\hline $13-1320$ & $\begin{array}{l}\text { Irradiated Fissile Material Storage } \\
\text { Facilities }\end{array}$ & A & $\begin{array}{l}\text { Applicable to Process Bays and Process } \\
\text { Water Tank Room }\end{array}$ \\
\hline-1 & Coverage & NA & Information only \\
\hline-2 & Objectives & A & Design objectives \\
\hline-3 & Nuclear Criticality Safety & A & SAR requirement \\
\hline-4 & Special Design Features & $\mathrm{A}$ & SAR requirement \\
\hline-5 & Confinement Systems & A & SAR requirement \\
\hline-6 & Effluent Control and Monitoring & A & SAR requirement \\
\hline-7 & Decontamination and Decommissioning & A & SAR requirement \\
\hline Division 14 & Conveying Systems & A & SAR requirement for crane \\
\hline Division 15 & Mechanical & A & SAR requirement \\
\hline $15-1525$ & Mechanical Insulation & A & $\begin{array}{l}\text { SAR requirement only for safe surface } \\
\text { temperatures (Sec 1525-4) }\end{array}$ \\
\hline-4 & Safe Surface Temperatures & A & SAR requirement for occupational safety \\
\hline $15-1530$ & Fire Protection & A & SAR requirement \\
\hline-1 & General & A & SAR requirement \\
\hline-2 & $\begin{array}{l}\text { Improved Risk Concept for Fire } \\
\text { Protection Systems }\end{array}$ & A & SAR requirement \\
\hline-3 & $\begin{array}{l}\text { Water Flow and Pressure Requirements } \\
\text { for Fire Protection }\end{array}$ & A & SAR requirement \\
\hline-4 & Automatic Sprinkler Protection & A & SAR requirement \\
\hline-5 & Special Protection Systems & NA & None in design \\
\hline-6 & Standpipes and Hose Systems & A & SAR requirement \\
\hline-7 & Portable Fire Extinguishers & A & SAR requirement \\
\hline-8 & Fire Detection and Alarm Systems & A & SAR requirement \\
\hline-9 & Water Storage and Distribution & A & SAR requirement \\
\hline-99 & Special Facilities & A & Classified as a Special Facility \\
\hline-99.0 & Nonreactor Nuclear Facilities - General & A & $\begin{array}{l}\text { Classified as a Nonreactor Nuclear } \\
\text { Facility }\end{array}$ \\
\hline
\end{tabular}


Table A-2. Screening of Process and Facility Design, Safety or Safety Analysis Report Required Applicable Sections of DOE Order 6430.1A for Chapters 2.0 and 3.0 of the Design Requirements Document. (10 sheets)

\begin{tabular}{|c|c|c|c|}
\hline Section no. & Title & Applicable & Justification \\
\hline $15-1540$ & Plumbing/Service Piping & A & SAR requirement \\
\hline-1 & General & A & SAR requirement \\
\hline-99 & Special Facilities & A & Classified as a Special Facility \\
\hline-99.0 & Nonreactor Nuclear Facilities - General & A & $\begin{array}{l}\text { Classified as a Nonreactor Nuclear } \\
\text { Facility }\end{array}$ \\
\hline $15-1550$ & $\begin{array}{l}\text { Heating, Ventilating and } \\
\text { Air-Conditioning Systems }\end{array}$ & A & $\begin{array}{l}\text { SAR requirement for ventilation-exhaust } \\
\text { systems only }\end{array}$ \\
\hline-1 & General Sizing and Design Criteria & A & $\begin{array}{l}\text { SAR requirement for ventilation-exhaust } \\
\text { systems, Sec. } 1550-1.5 \text {, only }\end{array}$ \\
\hline-1.5 & $\begin{array}{l}\text { Ventilation-Exhaust Systems Design } \\
\text { Requirements }\end{array}$ & A & $\begin{array}{l}\text { SAR requirement for ventilation-exhaust } \\
\text { systems }\end{array}$ \\
\hline-2 & $\begin{array}{l}\text { Heating, Ventilating and } \\
\text { Air-Conditioning Systems Selection }\end{array}$ & A & $\begin{array}{l}\text { Required for fire protection requirements } \\
\text { of ventilation equipment. }\end{array}$ \\
\hline-2.5 & $\begin{array}{l}\text { Air Handling and Air Distribution } \\
\text { Systems. }\end{array}$ & A & $\begin{array}{l}\text { Required for fire protection requirements } \\
\text { of ventilation equipment. }\end{array}$ \\
\hline-3 & Testing, Adjusting and Balancing & A & SAR requirement \\
\hline-99 & Special Facilities & A & Classified as a Special Facility \\
\hline-99.0 & Nonreactor Nuclear Facilities - General & A & $\begin{array}{l}\text { Classified as a Nonreactor Nuclear } \\
\text { Facility }\end{array}$ \\
\hline $15-1555$ & $\begin{array}{l}\text { Central Plant Heat } \\
\text { Generation/Distribution }\end{array}$ & NA & Not required by SAR \\
\hline $15-1565$ & Refrigeration & NA & Not required by SAR \\
\hline $15-1574$ & Cryogenic Systems & NA & None in design \\
\hline $15-1589$ & Air Pollution Control & A & SAR requirement \\
\hline-1 & General & A & SAR requirement \\
\hline-2 & Improved Risk Concept & A & SAR requirement \\
\hline-3 & Planning for Air Pollution Control & A & SAR requirement \\
\hline-4 & Combustion Process Installations & NA & None in design \\
\hline-5 & Refuse Disposal Facilities & NA & None in design \\
\hline-6 & $\begin{array}{l}\text { Gas Cleaning Equipment and Emission } \\
\text { Control Devices }\end{array}$ & NA & None in design \\
\hline-7 & Storage Facility for Volatile Liquids & NA & None in design \\
\hline-99 & Special Facilities & A & Classified as a Special Facility \\
\hline-99.0 & Nonreactor Nuclear Facilities - General & A & $\begin{array}{l}\text { Classified as a Nonreactor Nuclear } \\
\text { Facility }\end{array}$ \\
\hline
\end{tabular}


Table A-2. Screening of Process and Facility Design, Safety or Safety Analysis Report Required Applicable Sections of DOE Order 6430.1A for Chapters 2.0 and 3.0 of the Design Requirements Document. (10 sheets)

\begin{tabular}{|c|c|c|c|}
\hline Section no. & Title & Applicable & Justification \\
\hline $15-1595$ & Controls & A & $\begin{array}{l}\text { SAR requirement for ventilation-exhaust } \\
\text { systems only }\end{array}$ \\
\hline-1 & General & A & SAR requirement \\
\hline-2 & Zoning & A & SAR requirement \\
\hline-3 & Control Setback and Shutoff Devices & NA & Not required by SAR \\
\hline-4 & Humidity Control & NA & Not required by SAR \\
\hline-5 & Simultaneous Heating and Cooling & NA & Not required by SAR \\
\hline-6 & Control of Air Handling Systems & A & $\begin{array}{l}\text { SAR requirement for ventilation control, } \\
\text { damper control, and fire and smoke } \\
\text { detection and protection controls }\end{array}$ \\
\hline-6.1 & Mechanical Ventilation Control & A & SAR requirement \\
\hline-6.3 & Automatic Control Dampers & A & SAR requirement \\
\hline-6.5 & $\begin{array}{l}\text { Fire and Smoke Detection and Protection } \\
\text { Controls }\end{array}$ & A & SAR requirement \\
\hline-7 & $\begin{array}{l}\text { Control of Chilled and Hot Water } \\
\text { Distribution Systems }\end{array}$ & NA & Not required by $S A R$ \\
\hline-8 & $\begin{array}{l}\text { Cooling Tower and Water-Cooled } \\
\text { Condenser System Controls }\end{array}$ & NA & Not required by $S A R$ \\
\hline-9 & Control of Steam Systems & NA & None in design \\
\hline-10 & Energy Management Systems & NA & Not required by SAR \\
\hline-11 & Energy Metering & NA & Not required by $S A R$ \\
\hline Division 16 & Electrical & A & $\begin{array}{l}\text { SAR requirement for safety related } \\
\text { functions. Those functions are fire } \\
\text { detection and alarming, radiation } \\
\text { monitoring (RAMs and CAMs) and } \\
\text { alarming, emergency lighting, emergency } \\
\text { access and egress, and Safety Class } \\
\text { Instrumentation \& Control. See Electrical } \\
\text { System assumptions. }\end{array}$ \\
\hline $16-1600$ & General Requirements & NA & Reference only \\
\hline $16-1605$ & Basic Electrical Materials and Methods & A & SAR requirement \\
\hline-1 & General & A & SAR requirement \\
\hline-2 & Wiring Systems & A & SAR requirement \\
\hline $16-1620$ & Power Generation & NA & Not required by $\mathrm{SAR}$ \\
\hline $16-1630$ & Exterior Electrical Utility Service & A & SAR requirement for electrical safety only \\
\hline-1 & General & NA & $\begin{array}{l}\text { Not required by SAR for electrical safety } \\
\text { or fire protection. }\end{array}$ \\
\hline
\end{tabular}


Table A-2. Screening of Process and Facility Design, Safety or Safety Analysis Report Required Applicable Sections of DOE Order 6430.1A for Chapters 2.0 and 3.0 of the Design Requirements Document. (10 sheets)

\begin{tabular}{|c|c|c|c|}
\hline Section no. & Title & Applicable & Justification \\
\hline-2 & Supply Equipment and Facilities & NA & $\begin{array}{l}\text { Not required by SAR for electrical safety } \\
\text { or fire protection. }\end{array}$ \\
\hline-3 & Power Supply for Exterior Lighting & NA & Not required by SAR \\
\hline-4 & Power Supply for Buildings & NA & Not required by SAR \\
\hline-5 & Lightning Protection & A & SAR requirement \\
\hline-99 & Special Facilities & NA & No special facility requirements \\
\hline $16-1639$ & Grounding & A & SAR requirement for electrical safety only. \\
\hline-1 & General & A & SAR requirement for electrical safety only. \\
\hline-2 & $\begin{array}{l}\text { Substation and Switching Station } \\
\text { Grounding }\end{array}$ & NA & None in design \\
\hline-3 & Fence Grounding & NA & None in design \\
\hline-4 & Isolated Ground Systems & A & SAR requirement for electrical safety only. \\
\hline $16-1640$ & Interior Electrical Systems & A & $\begin{array}{l}\text { SAR requirement for alarm systems only. } \\
\text { Remaining systems covered by Sec. } \\
16-1605-1 \text {, General requirements. }\end{array}$ \\
\hline-3 & $\begin{array}{l}\text { Power Service for Security, } \\
\text { Communications, and Alarm Systems }\end{array}$ & A & SAR requirement \\
\hline-99 & Special Facilities & NA & No special facility requirements \\
\hline $16-1650$ & Exterior Lighting & NA & Not required by SAR \\
\hline $16-1655$ & Interior Lighting & A. & $\begin{array}{l}\text { SAR requirement for access and egress } \\
\text { safety. }\end{array}$ \\
\hline-1 & General & A & $\begin{array}{l}\text { SAR requirement for access and egress } \\
\text { safety. }\end{array}$ \\
\hline-2 & Lighting Sources & A & $\begin{array}{l}\text { SAR requirement for access and egress } \\
\text { safety. }\end{array}$ \\
\hline-3 & Fixtures & A & SAR requirement for fire safety \\
\hline-99 & Special Facilities & NA & No special facility requirements \\
\hline $16-1660$ & Special Systems & A & $\begin{array}{l}\text { SAR requirement for fire detection and } \\
\text { alarm systems, radiation monitoring and } \\
\text { alarming systems, and emergency } \\
\text { lighting. }\end{array}$ \\
\hline-1 & General & A & SAR requirement \\
\hline-2 & Emergency Power Systems & A & $\begin{array}{l}\text { SAR requirement for standby power } \\
\text { systems for these functions: fire detection } \\
\text { and alarming system, radiation monitoring } \\
\text { and alarming system, emergency lighting, } \\
\text { and communications. }\end{array}$ \\
\hline
\end{tabular}


Table A-2. Screening of Process and Facility Design, Safety or Safety Analysis Report Required Applicable Sections of DOE Order 6430.1A for Chapters 2.0 and 3.0 of the Design Requirements Document. (10 sheets)

\begin{tabular}{|c|c|c|c|}
\hline Section no. & Title & Applicable & Justification \\
\hline-3 & Uninterruptible Power Systems & A & $\begin{array}{l}\text { SAR requirement for fire detection and } \\
\text { alarming system and radiation monitoring } \\
\text { and alarming system. }\end{array}$ \\
\hline-99 & Special Facilities & A & Classified as a Special Facility \\
\hline-99.0 & Nonreactor Nuclear Facilities - General & A & $\begin{array}{l}\text { Classified as a Nonreactor Nuclear } \\
\text { Facility }\end{array}$ \\
\hline-99.0 .1 & $\begin{array}{l}\text { Safety Class (Emergency) Electrical } \\
\text { Systems }\end{array}$ & A & $\begin{array}{l}\text { SAR requirement for Safety Class } \\
\text { Instrumentation \& Control System only. }\end{array}$ \\
\hline-99.0 .2 & $\begin{array}{l}\text { Protection System and Instrumentation } \\
\text { and Controls }\end{array}$ & A & $\begin{array}{l}\text { SAR requirement for Safety Class } \\
\text { Instrumentation \& Control System only. }\end{array}$ \\
\hline-99.0 .3 & Qualification & A & $\begin{array}{l}\text { SAR requirement for Safety Class } \\
\text { Instrumentation \& Control System only. }\end{array}$ \\
\hline-99.0 .4 & Separation and Physical Protection & A. & $\begin{array}{l}\text { SAR requirement for Safety Class } \\
\text { Instrumentation \& Control System only. }\end{array}$ \\
\hline-99.0 .5 & Test and Calibration & A & $\begin{array}{l}\text { SAR requirement for Safety Class } \\
\text { Instrumentation \& Control System only. }\end{array}$ \\
\hline-99.0 .6 & Power Sources & A & $\begin{array}{l}\text { SAR requirement for Safety Class } \\
\text { Instrumentation \& Control System only. }\end{array}$ \\
\hline-99.0 .7 & Control Areas & A & $\begin{array}{l}\text { SAR requirement for Safety Class } \\
\text { Instrumentation \& Control System only. }\end{array}$ \\
\hline $16-1670$ & $\begin{array}{l}\text { Exterior Communications and Alarm } \\
\text { Systems }\end{array}$ & A & SAR requirement \\
\hline-1 & General & NA & Not required by SAR \\
\hline-2 & Fire Alarm and Supervisory Systems & A & SAR requirement \\
\hline-3 & Security Alarm and Assessment Systems & NA & None in design \\
\hline-4 & Secure Communications Systems & NA & None in design \\
\hline-5 & $\begin{array}{l}\text { Energy Management Systems and } \\
\text { Devices }\end{array}$ & NA & None in design \\
\hline-6 & Antenna Towers, Poles, and Masts & NA & None in design \\
\hline $16-1671$ & $\begin{array}{l}\text { Interior Communications and Alarm } \\
\text { Systems }\end{array}$ & A & SAR requirement \\
\hline-1 & Planning & NA. & Not required by $S A R$ \\
\hline-2 & Fire Alarm and Supervisory Systems & A & SAR requirement \\
\hline $16-1685$ & Electric Space Heating & NA & Not required by SAR \\
\hline 16-1694 & Energy Conservation & NA & None in design \\
\hline
\end{tabular}


HNF-SD-SNF-DRD-002 REV 1

This page intentionally left blank. 
HNF-SD-SNF-DRD-002 REV 1

\section{APPENDIX B \\ U.S. NUCLEAR REGULATORY COMMUSSION \\ EQUIVALENCY REQUTREMENTS}




\section{HNF-SD-SNF-DRD-002 REV 1}

This page intentionally left blank. 


\section{APPENDIX B \\ U.S. NUCLEAR REGULATORY COMMISSION EQUIVALENCY REQUIREMENTS}

\section{U.S. NUCLEAR REGULATORY COMMISSION REGULATIONS}

The U.S. Department of Energy (DOE) established in the K Basin Spent Nuclear Fuel (SNF) Project - Regulatory Policy, dated August 4, 1995, the requirement for the SNF Project facilities to achieve "nuclear safety equivalency" comparable to U.S. Nuclear Regulatory Commission (NRC) licensed facilities. An evaluation was performed to identify any additional requirements that were needed to supplement the existing and applicable DOE requirements to establish nuclear safety equivalency with the NRC licensed facilities. The additional requirements were consolidated into 29 items. All items are to be implemented per the NRC regulations with the exception of the design earthquake which will be implemented in a manner that established equivalence in safety, as opposed to direct equivalence to the regulation.

This document presents the applicability status for Cold Vacuum Drying Facility (CVDF) design and construction activities of the 29 additional NRC requirements from HNF-SD-SNF-DB-003, Spent Nuclear Fuel Path Forward Additional NRC Requirements, Rev. 2. These design and construction activities will develop structures, systems and components for the CVDF project.

\begin{tabular}{|c|c|c|}
\hline $\begin{array}{l}\text { Item } \\
\text { no. }\end{array}$ & Additional NRC requirement & Discussion \\
\hline 1 & $\begin{array}{l}\text { Evaluate Adequacy of Fire } \\
\text { Protection Design per DOE } \\
5480.7 \mathrm{~A} \text { and } 6430.1 \mathrm{~A} \text { against } \\
\text { Part } 50 \text { Appendix } R \text { and Take } \\
\text { into Account Section } 72.1220\end{array}$ & $\begin{array}{l}\text { Applicable - Fire Hazards Analysis (FHA) is in development to reflect } \\
\text { adequacy of CVD facility design as measured against Part } 50 \text { Appendix R } \\
\text { and Section } 72.122 \text { (c). As required by HNF-SD-SNF-DB-003, the FHA } \\
\text { and final design of the CVD facility will be evaluated to determine if } \\
\text { additional requirements of } 19 \text { CFR50, Appendix R are appropriate for the } \\
\text { facility. No change to the CVD facility design is expected to result from } \\
\text { this evaluation. }{ }^{* *} \text { (Roof non-combustibility is an open issue) ** }\end{array}$ \\
\hline \multirow[t]{3}{*}{2} & $\begin{array}{l}\text { Adopt Seismic Criteria in } \\
\text { HNF-SD-SNF-DB-004 }\end{array}$ & $\begin{array}{l}\text { Applicable - Seismic design of the CVD facility is in accordance with } \\
\text { HNF-SD-SNF-DB-004. CVD facility will be PC-3 (Safety Significant per } \\
\text { CM-4-46 })\end{array}$ \\
\hline & $\begin{array}{l}\text { Incorporate Design Basis } \\
\text { Tornado for SC-1 SSCs }\end{array}$ & $\begin{array}{l}\text { Applicable - Evaluation of CVD facility designs for tornado effects is } \\
\text { underway. }{ }^{* *} \text { Probabilistic evaluation of tornado impacts has been } \\
\text { completed and determined that tornado generated missile impacts on CVD } \\
\text { safety class equipment were not credible. }{ }^{* *}\end{array}$ \\
\hline & $\begin{array}{l}\text { Ensure Sharing of Utilities and } \\
\text { Services and Physical } \\
\text { Interaction do not Impair } \\
\text { Performance of Safety } \\
\text { Functions }\end{array}$ & $\begin{array}{l}\text { Applicable - However, to date, no active Safety Class } 1 \text { utilities or services } \\
\text { have been identified for the CVD facility. Any CVD facility } \\
\text { utility/services interfaces which come into existence when the design is } \\
\text { completed will be designed so as not to interfere with performance of } \\
\text { safety functions. }\end{array}$ \\
\hline
\end{tabular}




\begin{tabular}{|c|c|c|}
\hline $\begin{array}{l}\text { Item } \\
\text { no. }\end{array}$ & Additional NRC requirement & Discussion \\
\hline 3 & $\begin{array}{l}\text { SC-1 Electrical Equipment } \\
\text { Qualification }\end{array}$ & $\begin{array}{l}\text { Applicable - However, no Safety Class } 1 \text { electrical systems have been } \\
\text { identified for the CVD facility. }\end{array}$ \\
\hline 4 & $\begin{array}{l}\text { ISMP to Require Evaluation of } \\
\text { Loss of AC Power in SARs }\end{array}$ & $\begin{array}{l}\text { Applicable - The CVD facility Performance Spec. (WHC-S-0435, Rev 0) } \\
\text { and related design directions requires accommodation of loss of off-site } \\
\text { (AC) power for up to } 48 \text { hrs. Integrated Safety Management Plan will be } \\
\text { issued by WHC. }\end{array}$ \\
\hline 5 & $\begin{array}{l}\text { Incorporate Requirements of } \\
\text { IEEE Std } 484 \text { - Installation } \\
\text { Design of Large Lead Storage } \\
\text { Batteries - into Design }\end{array}$ & $\begin{array}{l}\text { Applicable - However, no Safety Class large lead storage batteries are in } \\
\text { current design. }\end{array}$ \\
\hline 6 & $\begin{array}{l}\text { Incorporate Requirements of } \\
\text { IEEE Std } 535 \text { - Qualification of } \\
\text { Class 1E Lead Storage } \\
\text { Batteries - into Design }\end{array}$ & $\begin{array}{l}\text { Applicable - However, no Safety Class electrical systems are required in } \\
\text { current design. Battery backup power (Safety-significant) for the control } \\
\text { room computer equipment and PLC's have been incorporated into the } \\
\text { design. It is not an equivalency requirement that IEEE std. } 535 \text { be applied } \\
\text { to these batteries. }\end{array}$ \\
\hline 7 & $\begin{array}{l}\text { Incorporate Requirements of } \\
\text { IEEE Std } 603 \text { - Criteria for } \\
\text { I\&C Safety Systems - for SC-1 } \\
\text { I\&C Items }\end{array}$ & $\begin{array}{l}\text { Applicable - Safety Class electrical I\&C systems are required for the } \\
\text { current CVD facility design. All Safety Class or Safety-significant } \\
\text { interlocks are expected to be "hard-wired" and rely on "relay logic" rather } \\
\text { than computers. }\end{array}$ \\
\hline 8 & $\begin{array}{l}\text { Incorporate Criticality Accident } \\
\text { Alarm System Requirements } \\
\text { from ANSI/ANS-8.3-1986 into } \\
\text { Design }\end{array}$ & $\begin{array}{l}\text { Normal Practice - A DOE required safety analysis (CVD facility SAR Ch. } \\
6 \text { and CSER updates) will evaluate the potential of an inadvertent } \\
\text { criticality in consideration of the new activities. Determination of the need } \\
\text { for a Criticality Accident Alarm System will be based on the results of this } \\
\text { analysis. It is not anticipated that additional Criticality Accident Alarm } \\
\text { System instrumentation will be required in the CVD facility design. }\end{array}$ \\
\hline 9 & $\begin{array}{l}\text { Review NRC Guidance for } \\
\text { Human Factors (NUREG-0700 } \\
\text { and SRP 18.1) against DOE } \\
6430.1 \mathrm{~A}, \text { Section } 1300-12.4 \\
\text { and DOE draft Standard } \\
\text { Human Factors Eng. Design } \\
\text { Criteria: Vol. Ito Identify } \\
\text { Appropriate Additional } \\
\text { Guidance. }\end{array}$ & $\begin{array}{l}\text { Applicable - The NRC limited the application of NUREG-0700 to review } \\
\text { of main control rooms and remote shutdown panels. The NRC did not } \\
\text { extend application of NUREG-0700 to, for example, nuclear power plant } \\
\text { radwaste control rooms or control stations used to support refueling } \\
\text { activities. The CVD facility design contains a control room and remote } \\
\text { shutdown monitoring stations in the process bays. As such, the control } \\
\text { room and monitoring stations are simplistic, rather than complex for which } \\
\text { NUREG-0700 was envisioned. In consideration of the above, a graded } \\
\text { approach to the application of NUREG-0700 will be applied. }\end{array}$ \\
\hline 10 & $\begin{array}{l}\text { Use Reg. Guide } 1.26 \text { for } \\
\text { ASME Section III Code Class } \\
\text { Assistance }\end{array}$ & $\begin{array}{l}\text { Applicable - An evaluation of the contribution of Reg. Guide } 1.26 \text { to code } \\
\text { class identification assistance for ASME Section III items in the CVD } \\
\text { facility design will be performed. Currently no CVD facility ASME } \\
\text { Section III Code items have been identified. }\end{array}$ \\
\hline 11 & $\begin{array}{l}\text { Use Reg. Guides } 1.84 \text { and } 1.85 \\
\text { for screening ASME Section III. } \\
\text { Code Cases for SC-1 }\end{array}$ & $\begin{array}{l}\text { Currently no CVD facility ASME Section III Code items have been } \\
\text { identified. Therefore a need for ASME Code cases has not been identified. }\end{array}$ \\
\hline 12 & $\begin{array}{l}\text { Ensure ANSI/ANS N509 and } \\
\text { N510 used in design of SC-2 } \\
\text { and } 3 \text { HVAC systems }\end{array}$ & $\begin{array}{l}\text { Normal Practice - ANSU/ANS N509 and N510 will be used in design of } \\
\text { Safety-significant CVD facility HVAC systems. }\end{array}$ \\
\hline
\end{tabular}


HNF-SD-SNF-DRD-002 REV 1

\begin{tabular}{|c|c|c|}
\hline $\begin{array}{c}\text { Item } \\
\text { no. }\end{array}$ & Additional NRC requirement & Discussion \\
\hline 13 & $\begin{array}{l}\text { Incorporate Design Reqs. of } \\
\text { ANSI/ANS }-57.1 \text { and } 57.2 \text { for } \\
\text { Cranes. }\end{array}$ & $\begin{array}{l}\text { Evaluation of ANSI/ANS } 57.1 \text { and } 57.2 \text { for additional design requirements } \\
\text { has not been completed. It is anticipated that the CVD facility crane } \\
\text { design criteria will be tailored to fit the XSAM (eXtra SAfety \& } \\
\text { Monitoring) crane series design criteria (essentially CMAA Spec. 74, } \\
\text { supplemented by appropriate seismic req., e.g., ASME NOG-1 } \\
\text { equivalency). }\end{array}$ \\
\hline 14 & $\begin{array}{l}\text { Incorporate Design Reqs. of } \\
\text { Generic Letters } 88-14,89-10 \\
89-13\end{array}$ & $\begin{array}{l}\text { Partially Applicable - Comparison of the requirements of two of these } \\
\text { NRC Generio letters (for Safety Class instrument air systems and } \\
\text { motor-operated valves) with the CVD facility design is not expected to } \\
\text { impose new requirements. The third letter, on open cycle cooling water } \\
\text { systems, does not apply to the CVD facility design. }\end{array}$ \\
\hline 15 & $\begin{array}{l}\text { Reporting of Defects and } \\
\text { Non-Compliances per WHC } \\
\text { Procurement Clause E13 }\end{array}$ & $\begin{array}{l}\text { Being Implemented - Procurement documents for Safety Class items and } \\
\text { services will include a requirement to report defects and non-compliances. }\end{array}$ \\
\hline 16 & $\begin{array}{l}\text { DOE Approval of QA Program } \\
\text { and Implementation Plan } \\
\text { Changes }\end{array}$ & $\begin{array}{l}\text { Being Implemented - Compliance with this criterion will be met by the } \\
\text { SNF Project QA organization. The subject activities will be performed in } \\
\text { accordance with the appropriate QA programs and procedures. }\end{array}$ \\
\hline 17 & $\begin{array}{l}\text { Occurrence Reporting System } \\
(10 \mathrm{CFR} 50.55(\mathrm{e}))\end{array}$ & $\begin{array}{l}\text { Being Implemented - This requirement will be met by the SNF Project. } \\
\text { The subject activities will be performed in accordance with the appropriate } \\
\text { SNFP procedures as required by the SNF Project. }\end{array}$ \\
\hline 18 & $\begin{array}{l}\text { Changes to Existing PMHC } \\
\text { Procedures and Instructions }\end{array}$ & $\begin{array}{l}\text { Being Implemented - Compliance with this requirement is being met by } \\
\text { the SNF Project. The subject activities will be performed in accordance } \\
\text { with the appropriate PMHC procedures and instructions. }\end{array}$ \\
\hline 19 & $\begin{array}{l}\text { Identify Potentially Defective } \\
\text { Safety Class Equipment per } \\
\text { Commercial Nuclear Power } \\
\text { Industry \& Audits of Safety } \\
\text { Class Purchased Material, } \\
\text { Equipment and Service } \\
\text { Suppliers }\end{array}$ & $\begin{array}{l}\text { Being Implemented - The SNF Project QA organization will ensure that } \\
\text { proper quality assurance documentation and controls are applied to all } \\
\text { Safety Class components in accordance with existing WHC procedures } \\
\text { and instructions. }\end{array}$ \\
\hline \multirow[t]{2}{*}{20} & $\begin{array}{l}\text { Access Control Devices for } \\
\text { High Radiation Areas Conform } \\
\text { with Section } 20.1601 \text { and } \\
\text { Hourly Exposure Rate Limit } \\
\text { Incorporated from Section } \\
20.1003\end{array}$ & $\begin{array}{l}\text { Not Applicable - The CVD facility currently has no radiation areas that } \\
\text { exceed the } 0.1 \text { rern in one hour at } 30 \mathrm{~cm} \text { criterion. The subject activities } \\
\text { will however comply with } 10 \text { CFR } 835 \text { and the HSRCM-1. }\end{array}$ \\
\hline & $2 \mathrm{mrem} / \mathrm{hr}$ Public Dose & $\begin{array}{l}\text { Normal Practice - Radiological releases for the Hanford site from normal } \\
\text { operations and anticipated events is limited by DOE } 5400.5 \text { to } 100 \\
\text { mrem/yr to the public from all sources and pathways. In addition, for } \\
\text { CVD facility operations, releases to the public are expected to be } \\
\text { substantially less than } 10 \text { mrem/yr. Further, for normal operations and } \\
\text { anticipated events associated with the subject activities, no periodic } \\
\text { releases of a substantially higher magnitude are planned or expected. The } \\
\text { above provides reasonable assurance that the } 2 \text { mrem/hr public dose } \\
\text { criterion will not be exceeded. }\end{array}$ \\
\hline
\end{tabular}




\begin{tabular}{|c|c|c|}
\hline $\begin{array}{l}\text { Item } \\
\text { no. }\end{array}$ & Additional NRC requirement & Discussion \\
\hline 21 & $\begin{array}{l}\text { Apply Exposure Criteria of } \\
\text { Section } 72.104 \text { to Design for } \\
\text { Assessment of Annual Public } \\
\text { Dose }\end{array}$ & $\begin{array}{l}\text { Normal Practice - Radiological releases for the Hanford site from normal } \\
\text { operations and anticipated events is limited by DOE } 5400.5 \text { to } 100 \\
\text { mrem/yr to the public from all sources and pathways. In addition, for } \\
\text { CVD facility operations, releases to the public are expected to be } \\
\text { substantially less than } 10 \text { mrem/yr. The NRC criteria are } 25 \text { mrem whole } \\
\text { body, } 75 \text { mrem thyroid, and } 25 \text { mrem to other critical organs. The DOE } \\
\text { criteria are } 25 \text { mrem whole body and } 75 \text { mrem to critical organs (including } \\
\text { the thyroid). In consideration of the above, there is reasonable assurance } \\
\text { that the } 25 \text { mrem criterion for critical organs will be met. }\end{array}$ \\
\hline 22 & Onsite Worker Dose & $\begin{array}{l}\text { Not Applicable - This requirement is being deleted in consideration of a } \\
\text { change in the manner in which the Part } 72 \text { criterion for "important to } \\
\text { safety" is being implemented. As a result, DOE requirements control } \\
\text { onsite worker dose. }\end{array}$ \\
\hline 23 & ALARA - NRC Reg. Guide 8.8 & $\begin{array}{l}\text { Normal Practice - In consideration of the nature of the subject activities, } \\
\text { and that DOE } 6430.1 \text { A already references NRC Regulatory Guide } 8.8 \text { for } \\
\text { piping design considerations, it is believed that Regulatory Guide } 8.8 \text { is } \\
\text { being implemented. Considerations included among other items: } \\
\text { shielding, local ventilation, control panel locations, and the nature of } \\
\text { equipment associated with the subject activities. A design review against } \\
\text { the specifics of RG } 8.8 \text { for design issues will be performed. }\end{array}$ \\
\hline 24 & $\begin{array}{l}\text { SAR Update - to include } \\
\text { Information Required by NRC } \\
\text { Reg Guide } 3.26\end{array}$ & $\begin{array}{l}\text { Integrated Safety Management Plan is issued by SNFP. SAR input } \\
\text { provided by Merrick Engineers is as required by SNFP and is considered } \\
\text { to be compliant with the intent of NRC Reg. Guide } 3.26 \text {. }\end{array}$ \\
\hline 25 & $\begin{array}{l}\text { Review Effluent Monitoring } \\
\text { Requirements of 10CFR20, } \\
10 \text { CFR70.59, and 10CFR } 835 \\
\text { to Identify Instrumentation } \\
\text { Needed Due to Venting of } \\
\text { MCOs }\end{array}$ & $\begin{array}{l}\text { Partially Applicable - Liquid effluents (bulk water from the MCO's) and } \\
\text { gaseous effluents (e.g., Kr- } 85 \text {, hydrogen) have been analyzed to be in } \\
\text { compliance with regulatory requirements. CVD facility design } \\
\text { incorporates required instrumentation. }\end{array}$ \\
\hline 26 & $\begin{array}{l}\text { General Design Criteria - } \\
\text { 10CFR50, App. A. }\end{array}$ & $\begin{array}{l}\text { Not Applicable - There are no specific 10CFR50, App. A applicable } \\
\text { criteria for the CVD facility. }\end{array}$ \\
\hline 27 & $\mathrm{~K}_{\mathrm{eff}}$ of 0.95 & $\begin{array}{l}\text { Applicable - The SNF CVD facility design has incorporated a maximum } \\
\mathrm{K}_{\text {eff }} \text { of } 0.95 \text { according to accepted practice. }\end{array}$ \\
\hline 28 & $\begin{array}{l}\text { Review ANSI/ANS-57.9 to } \\
\text { Identify Additional Design } \\
\text { Requirements }\end{array}$ & $\begin{array}{l}\text { Not Applicable }-* * \text { However, studies to analyze CVD facility design } \\
\text { relative to } 5 \% \text { dead load and tornado loading are complete for the CVD } \\
\text { process bay design areas and have been shown to be acceptable.** }\end{array}$ \\
\hline 29 & $\begin{array}{l}\text { Part } 72 \text { - Identify SSCs } \\
\text { Important to Safety in } \\
\text { Accordance with } 10 \text { CFR } 72.3 \\
\text { as Implemented through } \\
\text { Section } 72.106 . \text { Impose } \\
\text { CM-4-46 } \\
\text { SC-1 in Items Identified as } \\
\text { Important to Safety. }\end{array}$ & Not applicable to the CVDF. \\
\hline
\end{tabular}

${ }^{1} \mathrm{CM}-4-46$ is superceeded by HNF-PRO-430, $-509,-510,-511,-513,-514$, and 
HNF-SD-SNF-DRD-002 REV 1

APPENDIX C

DEFINITION OF LOW SPECIFIC ACTIVITY MATERIAL 
HNF-SD-SNF-DRD-002 REV 1

This page intentionally left blank. 


\section{APPENDIX C DEFINITION OF LOW SPECIFIC ACTIVITY MATERIAL}

Low specific activity material means any of the following (10 CFR 71, Subpart 71.4):

1. Uranium or thorium ores and physical or chemical concentrates of those ores

2. Unirradiated natural or depleted uranium or unirradiated natural thorium

3. Tritium oxide in aqueous solutions provided the concentration does not exceed 5.0 millicuries per milliliter

4. Material in which the radioactivity is essentially uniformly distributed and in which the estimated average concentration per gram of contents does not exceed

i. 0.0001 millicurie of radionuclides for which the A2 quantity in Appendix A of 10 CFR 71 is not more than 0.05 curie

ii. 0.005 millicurie of radionuclides for which the A2 quantity in Appendix A of 10 CFR 71 is more than 0.05 curie but not more than 1 curie, or

iii. 0.3 millicurie of radionuclides for which the A2 quantity in Appendix A of 10 CFR 71 is more than 1 curie

5. Objects of nonradioactive material externally contaminated with radioactive material provided that the radioactive material is not readily dispersible and the surface contamination when averaged over an area of 1 square meter does not exceed 0.0001 millicurie $(220,000$ disintegrations per minute) per square centimeter of radionuclides for which the A2 quantity in Appendix A of 10 CFR 71 is not more than 0.05 curie or 0.001 millicurie $(2,200,000$ disintegrations per minute) per square centimeter for other radionuclides. 


\section{HNF-SD-SNF-DRD-002 REV 1}

This page intentionally left blank. 
HNF-SD-SNF-DRD-002 REV 1

APPENDIX D

\section{PROCESS CONDITIONS OF OPERATION}




\section{HNF-SD-SNF-DRD-002 REV 1}

This page intentionally left blank. 


\section{APPENDIX D \\ PROCESS CONDITIONS OF OPERATION}

\section{NORMAL CONDITIONS OF OPERATIONS (LEVEL A)}

Level A event design frequencies have been arbitrarily increased by a factor of one-third above the planned frequency to provide margin for unanticipated operations. Frequencies apply to each process bay. Four process bays and 430 multicanister overpacks (MCOs) have been assumed. A 2-year operational period is assumed with a 6-month startup program.

\section{Event Descriptions}

A-0 Cask-Multicanister Overpack Receiving at a Cold Vacuum Drying Facility Process Bay (Frequency $=140 /$ Life per Process Bay)

The cask and vented $\mathrm{MCO}$ are moved in the vertical position to the Cold Vacuum Drying Facility (CVDF) for the drying cycle. The MCO is transferred on a special purpose transporter, and the $\mathrm{MCO}$ is not actively cooled during transport. The MCO containing spent nuclear fuel (SNF) is transferred from the $\mathrm{K}$ Basins in a water-flooded condition with the MCO vent path open through a single-stage, low-flow, high-efficiency particulate air (HEPA) filter (internal to the MCO).

The cask-MCO transporter is driven to the door of one of the four process bays, selected by the CVDF shift operations manager. At the CVDF, an "elephant trunk" exhauster is connected to the truck exhaust pipe to remove diesel fumes, the bay door is opened, and the trailer is positioned within the bay. The trailer is then jacked up using an on-board hydraulic motor and restrained to the foundation to allay seismic concerns. The truck is disconnected from the transporter trailer and driven out of the process bay. The process bay doors are closed, sealing the trailer within a confinement zone.

A group of receiving and inspection activities is performed next to verify that the $\mathrm{MCO}$ is properly labeled so that spent nuclear material accountability is maintained, to verify that there is no removable contamination on the exposed surfaces of the cask or MCO, and to assay the radiation field in the vicinity of the cask and MCO top where workers will be present. Decontamination and resurvey will occur if contamination is found.

A-1 Multicanister Overpack at Cold Standby Condition at $15^{\circ} \mathrm{C}\left(59^{\circ} \mathrm{F}\right)$ (Frequency $=10 /$ Life per Process Bay)

The objective of this event is to maintain the $\mathrm{MCO}$ vessel at a temperature of $15^{\circ} \mathrm{C}\left(59^{\circ} \mathrm{F}\right)$ for system stability. At this temperature, the reaction rate of water and oxygen with the 
SNF is minimal. This temperature will maintain the SNF in a safe condition prior to the vacuum drying operation. Note that this operational step shall be considered optional depending on the outcome of the required thermal analyses. Direct-to-drying upon receipt of the MCO may be accomplished without first going to the cold standby condition.

The initial cold standby operation commences after the cask-MCO is placed in a vacuum drying process bay and the MCO tempered water system (TWS) is connected. The TWS cooling water flow is started to reduce the temperature of the average $\mathrm{MCO}$ vessel wall to $15^{\circ} \mathrm{C}\left(59^{\circ} \mathrm{F}\right)$. The initial $\mathrm{MCO}$ wall temperature (following receipt at the vacuum process bay) is determined from analysis based upon the design of the cask-MCO transporter, supplemental shielding, transport time, and assumed environmental conditions. A helium purge of 0.06 standard $\mathrm{m}^{3} / \mathrm{min}$ to 0.14 standard $\mathrm{m}^{3} / \mathrm{min}$ ( 2 to 5 standard $\mathrm{ft}^{3} / \mathrm{min}$ ) with an MCO gauge pressure of $21 \mathrm{kPa}\left(3 \mathrm{lb} / \mathrm{in}^{2}\right.$ [900 torr] $)$ is maintained during cold standby.

The cold standby condition will also be achieved following any off-normal events where the normal drying operation is not completed as scheduled. The primary action of the cold standby condition is to reduce the $\mathrm{MCO}$ average wall temperature to $15^{\circ} \mathrm{C}\left(59^{\circ} \mathrm{F}\right)$.

A-2 Multicanister Overpack Heatup to $50^{\circ} \mathrm{C}\left(122^{\circ} \mathrm{F}\right)$

(Frequency $=140 /$ Life per Process Bay)

This event sequence starts with the $\mathrm{MCO}$ in the range of $15^{\circ} \mathrm{C}$ to $30^{\circ} \mathrm{C}\left(59^{\circ} \mathrm{F}\right.$ to $\left.86^{\circ} \mathrm{F}\right)$ prior to the initial water drain and inert gas purge (A-3) and with the MCO pressure at a gauge pressure of approximately $21 \mathrm{kPa}$ to $379 \mathrm{kPa}\left(3\right.$ to $\left.55 \mathrm{lbf} / \mathrm{in}^{2}\right)$. The MCO pressure is vented to the CVDF heating, ventilating, and air conditioning (HVAC) system through a temporary connection through the cask lid. Next the cask lid is removed, the cask-MCO seal ring-hood is installed, and the cask-MCO TWS and vacuum purge system (VPS) are connected to the cask and MCO. The vacuum line is opened to provide a vent path for the $\mathrm{MCO}$, and the cask-MCO annulus is filled with water from the temperature control system.

The MCO vessel heater system is activated and the temperature is increased in increments up to the maximum level of $50^{\circ} \mathrm{C}\left(122^{\circ} \mathrm{F}\right)$. The heatup rate shall be controlled to $10^{\circ} \mathrm{C} / \mathrm{hr}$ $\left(18^{\circ} \mathrm{F} / \mathrm{hr}\right)$ and is achieved by circulating heated water at the rate of $76 \mathrm{~L} / \mathrm{min}(20 \mathrm{gal} / \mathrm{min})$ in the cask-MCO annulus. Note that cask-MCO heatup is not allowed until the ventilation and MCO process penetrations are connected. During this operation, the annulus water shall be monitored for loss of flow or loss of water.

A-3 Multicanister Overpack Bulk Water Drain at $50^{\circ} \mathrm{C}\left(122^{\circ} \mathrm{F}\right)$ (Frequency $=140 /$ Life per Process Bay)

The objective of this event is to drain the MCO vessel of its bulk water and purge the MCO with an inert gas while maintaining an average $\mathrm{MCO}$ wall temperature of $50^{\circ} \mathrm{C}\left(122^{\circ} \mathrm{F}\right)$.

The initial removal of the bulk water from the $\mathrm{MCO}$ is accomplished by inert gas (helium) purging and/or suction pumping (nominal removal rate shall be $19 \mathrm{~L} / \mathrm{min}[5 \mathrm{gal} / \mathrm{min}]$ ). The 
bulk water is drained to the CVDF process water collection (PWC) system receiver tank. Water is removed to a preset limit of approximately $90 \%$ of the total volume, followed by a 20-minute hold period for drainage from the MCO's internal structures. Water removal then continues to remove the remaining $10 \%$ of the volume. Following bulk water draining, the MCO is purged with helium at the rate of 0.06 standard $\mathrm{m}^{3} / \mathrm{min}$ to 0.14 standard $\mathrm{m}^{3} / \mathrm{min}$ ( 2 to 5 standard $\mathrm{ft}^{3} / \mathrm{min}$ ) for approximately 30 to 60 minutes. This step partially dries the fuel and purges any accumulated hydrogen out of the MCO. The residual water removed by the vacuum system is collected in a condenser and then drained to the CVDF PWC system receiver tank.

Following this operation, free water is still left on the internal surfaces of the MCO, surfaces of the MCO internals, surfaces and cavities of the SNF elements and within any fuel corrosion product. Also a small heel, less than $0.3 \mathrm{~L}$ (10 liquid oz) of water, is left at the lower end of the axial process tube. Total residual free water (i.e., not chemically bound) content is estimated to be less than $32 \mathrm{~L}(8.5 \mathrm{gal})$.

\section{A-4 Normal Vacuum Pump Down and Inert Gas Purge at $50^{\circ} \mathrm{C}\left(122^{\circ} \mathrm{F}\right)$} (Frequency $=140 /$ Life per Process Bay)

The objective of this event is to evacuate the MCO to approximately $67 \mathrm{~Pa}(0.5$ torr $)$ and purge the $\mathrm{MCO}$ with an inert gas while maintaining an average $\mathrm{MCO}$ wall temperature of $50^{\circ} \mathrm{C}\left(122^{\circ} \mathrm{F}\right)$. The $\mathrm{MCO}$ is evacuated to an initial pressure in the range of $13 \mathrm{kPa}$ to $20 \mathrm{kPa}$ (100 to 150 torr) (depending on vapor pressure of water at the saturation temperature, $P_{\text {sat }}=92.5$ torr at $50^{\circ} \mathrm{C}$ ) by the vacuum pump system. A minimal inert gas purge, control valve position, or condenser operation is maintained on the MCO to prevent the water from freezing within the MCO by maintaining the pressure at $667 \mathrm{~Pa}$ (5 torr) or above within the MCO.

The $\mathrm{MCO}$ pressure rises as the mean temperature increases until the vacuum pump has removed the evolved gases; the pressure stabilizes at the saturated vapor pressure corresponding to mean temperature of the water vapor in the MCO.

The MCO is evacuated for up to 8 hours maximum by the vacuum pump system. If the pressure is less than $10 \mathrm{kPa}$ (75 torr) before that time, pumping will be continued until the pressure reaches $67 \mathrm{~Pa}$ ( 0.5 torr). If the pressure is not less than $10 \mathrm{kPa}$ ( 75 torr) at the end of the initial 8-hour period, a purge of helium in the range of 0.06 standard $\mathrm{m}^{3} / \mathrm{min}$ to 0.28 standard $\mathrm{m}^{3} / \mathrm{min}$ ( 2 to 10 standard $\mathrm{f}^{3} / \mathrm{min}$ ) at a total gauge pressure of $21 \mathrm{kPa}$ $\left(3 \mathrm{lbf} / \mathrm{in}^{2}\right)$ is performed for a minimum of 4 hours to reacheive stable temperatures within the MCO. The evacuation and helium purge process is repeated until the pressure setpoint of $10 \mathrm{kPa}$ (75 torr) is achieved. The second and any subsequent evacuation steps are held to a maximum 4-hour period and all purges are for a minimum of 4 hours. For the final evacuation step, the inert gas purge system and the condenser are isolated and the MCO total pressure decreases to the base capability of the vacuum pump (approximately $67 \mathrm{~Pa}$ [0.5 torr]); the unpurged condition has a time limit of 1 hour. 
To satisfy an initial drying criterion, a water vapor pressure of less than $400 \mathrm{~Pa}$ ( 3 torr) is required during a 1-hour hold period with the vacuum system isolated. An automatic pressure rebound test is carried out by closing valves to isolate the $\mathrm{MCO}$ and monitoring the pressure. The duration is approximately 15 minutes. The cold vacuum drying control system then predicts the pressure that would be reached if the test were extended an additional 45 minutes. If the prediction is $400 \mathrm{~Pa}$ ( 3 torr) or less, the hold period is continued for 45 minutes. If the prediction is greater than $400 \mathrm{~Pa}$ ( 3 torr), or the pressure is greater than $400 \mathrm{~Pa}$ ( 3 torr) after the 45 minute hold period, the purge and evacuation cycle is repeated.

Following the final unpurged pumpdown, the inert gas purge will be reintroduced and the pressure returned to a gauge pressure of $21 \mathrm{kPa}\left(3 \mathrm{lbf} / \mathrm{in}^{2}\right)$. The transition to shipping acceptance test gas evolution monitoring is then started (Event A-5).

A-5 System Heat up to $75^{\circ} \mathrm{C}\left(167^{\circ} \mathrm{F}\right)$ For Shipping Acceptance Test (Frequency $=140 /$ Life per process Bay)

A final processing step, a slow ramp $\left(\sim 5^{\circ} \mathrm{C} / \mathrm{hr}\left[\sim 9^{\circ} \mathrm{F} / \mathrm{hr}\right]\right)$ to $75^{\circ} \mathrm{C}\left(167^{\circ} \mathrm{F}\right)$, is performed to ensure that fuel reactions occurring during subsequent sealed transport at $75^{\circ} \mathrm{C}\left(167^{\circ} \mathrm{F}\right)$ or lower will be no more rapid than those during cold vacuum drying where pressure monitoring and venting capabilities are available. A minimum 6 -hour hold at $75^{\circ} \mathrm{C}$ $\left(167^{\circ} \mathrm{F}\right)$ will take place to ensure thermal equilibrium of the MCO.

Following heat up to $75^{\circ} \mathrm{C}\left(167^{\circ} \mathrm{F}\right)$ the total and partial pressures are monitored for the minimum 6 hour period, the partial pressure increase rates for hydrogen, water and krypton are measured and recorded. If the increase in partial pressure rates are less than prescribed limits (determined by Cask shipping requirements of $1.4 \mathrm{kPa} / \mathrm{hr}\left[0.2 \mathrm{lbf} / \mathrm{in}^{2} / \mathrm{hr}\right]$ ) then the MCO is suitable for shipping. If the limits are exceeded, then drying step A-4 is repeated.

A-6 System Cooldown to $15^{\circ} \mathrm{C}\left(59^{\circ} \mathrm{F}\right)$ for Cask-MCO Transport Preparation (Frequency $=140 /$ Life per Process Bay)

Following heatup to $75^{\circ} \mathrm{C}\left(167^{\circ} \mathrm{F}\right)$ and vacuum monitoring, the temperature is decreased at the maximum rate to $15^{\circ} \mathrm{C}\left(59^{\circ} \mathrm{F}\right)$ using the MCO TWS. The maximum cooldown rate for the average wall temperature is held at $10^{\circ} \mathrm{C} / \mathrm{hr}\left(18^{\circ} \mathrm{F} / \mathrm{hr}\right)$ or lower.

After the drying cycle, which fully reacts the free water in the $\mathrm{MCO}$ or removes the water as vapor, the dried MCO is backfilled with an inert gas (helium) and slightly pressurized to a gauge pressure of approximately $21 \mathrm{kPa}\left(3 \mathrm{lbf} / \mathrm{in}^{2}\right.$ [900 torr]), then isolated.

A-7 System Shutdown and Preparation for Cask-MCO Transport (Frequency $=140 /$ Life per Process Bay)

Upon acceptance of the drying process, the process connections are removed and $\mathrm{MCO}$ process port plugs replaced. The $\mathrm{MCO}$ connections are leak tested and verified to be 
acceptable to ship (leak rate less than $1.0 \times 10^{-3}$ standard $\mathrm{cm}^{3} / \mathrm{sec}$, test with bubble solution at a gauge pressure of $21 \mathrm{kPa}\left[3 \mathrm{lbf} / \mathrm{in}^{2}\right]$ of helium inside the $\mathrm{MCO}$ ). The cask-MCO TWS is isolated and the water in the annulus is drained to the PWC receiver tank. The annulus is purged with instrument air to dry the annulus.

The cask and MCO are prepared for shipping; the top of the MCO is decontaminated, and the cask is sealed by reinstalling the cask lid. The annulus is purged with and backfilled with helium to a gauge pressure of $21 \mathrm{kPa}\left(3 \mathrm{lbf} / \mathrm{in}^{2}\right)$. The cask annulus process connections are removed, and the cask ports are sealed. No leak checking of the cask is performed.

The cask trailer is disconnected from the process bay's physical restraints, the trailer is connected to the truck in a similar (but reverse) sequence to that described above in step A-0, then released for transport to the Canister Storage Building (CSB).

Prior to transport of the cask-MCO to the CSB, the CVDF operations shift manager shall receive acknowledgment from the CSB operations shift manager that the CSB is available, operational, and ready to receive a cask-MCO transporter.

The drained water from the cask-MCO annulus and vacuum system condenser is collected in the PWC receiver tank and then transferred to the CVDF PWC holding tank. The water is periodically removed by tanker truck and transferred to the KW-Basin Integrated Water Treatment System.

A-8 Hot Standby at $50^{\circ} \mathrm{C}\left(122^{\circ} \mathrm{F}\right)$ (Frequency $=10 /$ Life per Process Bay)

The hot standby condition is achieved by increasing the $\mathrm{MCO}$ temperature to $50^{\circ} \mathrm{C}$ $\left(122^{\circ} \mathrm{F}\right)$ using event sequence $\mathrm{A}-2$ and while maintaining a purge condition in the range of 0.06 standard $\mathrm{m}^{3} / \mathrm{min}$ to 0.14 standard $\mathrm{m}^{3} / \mathrm{min}$ ( 2 to 5 standard $\mathrm{f}^{3} / \mathrm{min}$ ) of helium flow with the $\mathrm{MCO}$ at a gauge pressure of $21 \mathrm{kPa}\left(3 \mathrm{lb} / \mathrm{in}^{2}\right.$ [900 torr]).

A-9 Multicanister Overpack Cold Vacuum Drying System Normal Emergency Shutdown and Restart

(Frequency $=10 /$ Life per Process Bay)

\section{Normal Emergency Shutdown}

Normal emergency shutdown is accomplished by first establishing a steady state condition at the cold standby condition via the CVDF monitor and control system (MCS) controller. The system is then shut down by the operator. The water outlet temperature setpoint is adjusted downward to $15^{\circ} \mathrm{C}\left(59^{\circ} \mathrm{F}\right)$ in 500 seconds to produce MCO temperature variations that are representative of the system during this event. 


\section{Restart to Standby Condition}

After steady state is achieved at cold standby, the purge and vacuum drying process is restarted and the load demand is increased to and held at the hot standby state under automatic control.

\section{UPSET CONDITIONS OF OPERATIONS (LEVEL B)}

\section{Event Descriptions}

\section{B-1 Loss of Normal Site Power (Frequency $=5 /$ Life per Process Bay)}

This event is defined as the sudden loss of site electrical power followed by a drying system emergency shutdown on low-MCO-TWS-flow trip signal. Immediately upon loss of site power, the primary pump has step drops in output due to loss of power and the chiller system coasts down. The facility backup batteries receive an initiating signal and provide emergency shutdown power. Subsystems that are employed for normal decay heat removal, such as the cask-MCO TWS, all fail to operate. The cask-MCO TWS control valves fail "as is" upon loss of electric power. (Note that proposed designs may consider an engineered safety feature to have the control valves fail to nominal cooling flow upon loss of power).

For this event an evaluation shall be made to determine the operating condition of the SNF due to initially increased MCO wall temperatures. During the initial transient, the $\mathrm{MCO}$ will reject heat principally through natural convection and thermal radiation to the process bay environment. Until normal power is restored, the MCO vessel will continue to cool toward ambient conditions.

Once normal power is available, the above components operate according to prescribed post-emergency operations to meet minimum flows and conditions for residual heat removal. After normal power is restored, the long term transient becomes more like a normal emergency shutdown (Event A-7). A new steady state equilibrium is eventually achieved at cold standby.

\section{B-2 Cask-Multicanister Overpack Tempered Water System Upsets}

Loss of Cooling Water Flow

(Frequency $=4 /$ Life)

This event sequence shall be described by the seller based upon final cooling system design. This event shall include the condition where there is a $50 \%$ loss of normal MCO tempered water cooling system flow. Loss of flow could result from either loss of pumps (mechanical or electrical failure), control and isolation valve closures, or pipe breaks. This event will 
result in a temperature rise in the $\mathrm{MCO}$ when cooling is lost. This will create temperature gradients in the shell and could possibly lead to seal failures and resulting air in leaks.

In the event that MCO temperature limits in the areas of the seals are reached, operator alarms are activated by the MCS and an orderly power runback and/or emergency shutdown of the drying system will be required until the faulty cooling system component can be repaired. The partial loss of cooling event results in a sudden approximate temperature increase, followed by a temperature down transient in the affected cooling system. It is experienced by the other operational cooling systems as a normal shutdown or emergency shutdown sequence.

Because of radiation heat transport coupling and physical isolation, these MCO cooling system events have negligible thermal-hydraulic impact on the MCO.

Excess Chilled Water to the Multicanister Overpack (Frequency $=4 /$ Life)

An excess cooling condition would result if the chilled water heat exchanger bypass valve were to abruptly admit excess chilled water beyond the demand signal. The transient could be minor if the modulating effect of a storage tank is assumed. The major transient would occur at zero SNF decay power where the MCO and cooling system could be cooled from $52{ }^{\circ} \mathrm{C}\left(125^{\circ} \mathrm{F}\right)$ to the chilled water supply temperature of approximately $0^{\circ} \mathrm{C}\left(32{ }^{\circ} \mathrm{F}\right)$.

Loss of Circulator Water

(Frequency $=4 /$ Life)

The normal heat sink for the MCO is the facility chilled water system, with the system giving up heat through heat exchangers to the environment. The chilled water system is not safety class, and it is assumed be individually lost and/or to fail during relevant accident conditions. A complete loss of the chilled water system is therefore a design condition for this system.

Upon complete loss of the chilled water heat sink, the cooling control logic responds to the thermal up transient by causing the chilled water bypass valve to run to full closed, attempting to send full flow to the heat exchangers.

Since the MCO temperature setpoint cannot be maintained, the controls verify and maintain both circulators operating. The coolant temperature in the cooling system gradually continues to increase, from the normal operating point of about $10^{\circ} \mathrm{C}\left(50^{\circ} \mathrm{F}\right)$, at about $10^{\circ} \mathrm{C} / \mathrm{hr}\left(18^{\circ} \mathrm{F} / \mathrm{hr}\right)$ to the maximum ambient condition of $45^{\circ} \mathrm{C}\left(113^{\circ} \mathrm{F}\right)$. If the chilled water cannot be restored within 15 minutes, the operator is required to initiate a planned shutdown.

A partial loss of chilled water results in a modest upward temperature transient. It is dealt with by modulating the chilled water heat exchanger bypass valve toward closure, sending increasing quantities of chilled water through the unit until the temperature setpoint can be 
met. If the MCO temperature continues to increase beyond a preset limit, an operator alarm is generated via the MCS, is decreased to ensure these temperatures remain within the specified limit. It should be noted that the effect on heat transfer from the $\mathrm{MCO}$ to the heating and cooling system caused by the elevated vessel temperatures will not greatly affect the heat transferred from the SNF although there may be increased chemical reactivity on the surface of the fuel.

During these events, the vacuum pumping system maintains the allowable total pressure, as shown in Table D-1. An evaluation shall be made to determine the operating condition of the vacuum system caused by increased MCO wall temperature. The increased material temperature increases the outgasing load to the vacuum system and thus increases the total pressure. Events that result in enhanced heat loads to the vacuum system may require the automatic shutdown of selected vacuum pumps because of overheating. The vacuum system cooling system will also experience a $50 \%$ reduction in cooling capability. No $\mathrm{MCO}$ in leakage above the design rate is expected.

Inadvertent Drain of Circulator Water

(Frequency $=4 /$ Life)

Excessive Heatup of Circulator Water

(Frequency $=4 / \mathrm{Life}$ )

B-3 Loss of Vacuum with Multicanister Overpack at $50^{\circ} \mathrm{C}\left(122^{\circ} \mathrm{F}\right)$

(Frequency $=2 /$ Life per Process Bay)

Vacuum system difficulties lead to loss of vacuum pumping and/or chamber pressure increases. The MCS shall alarm the operator as to its status and be prepared to isolate the MCO.

By technical specifications, the MCO will be brought to the cold shutdown state within 1 hour. The MCO may be returned to temperature when conditions are brought back within operating limits. No additional intrusion of gas species into the MCO is expected.

\section{B-4 Inadvertent Inert Gas Flood of Multicanister Overpack}

(Frequency $=2 /$ Life per Process Bay)

For this event, it is assumed that an inadvertent initiation of the inert gas purge of the MCO occurs with the MCO at maximum operating temperature. MCO pressure rises to atmospheric levels within 60 seconds. There is no leakage of air into the MCO. However, the introduction of oxygen and other reactive species by the purge system shall be assumed.

Pressure instrumentation in the inert gas purge control system detects this event and sends a signal to the protection system to request a system emergency shutdown. The SNF experiences an induced transient cooling due to the greater heat rejection to the MCO. The $\mathrm{MCO}$ heating and cooling system continues to operate under automatic control, in 
accordance with prescribed post-emergency shutdown operations. The system reaches equilibrium at the cold standby state.

The vacuum system trips off during this event and the $\mathrm{MCO}$ isolation valves close. During this event, the average $\mathrm{MCO}$ wall temperature is held at a nominal $50^{\circ} \mathrm{C}\left(122^{\circ} \mathrm{F}\right)$.

\section{EMERGENCY CONDITIONS OF OPERATIONS (LEVEL C)}

\section{Event Descriptions}

To be developed.

\section{FAULTED CONDITIONS OF OPERATIONS (LEVEL D)}

\section{Event Description}

D-1 Design Basis Earthquake

(Frequency $=1 /$ Life per Drying Facility)

For this transient, all safety-related structures, systems, and components important to safety shall be capable of withstanding the effects of the safe shutdown earthquake (SSE) without loss of capability to perform their safety functions. This ensures the capability to shut down the vacuum drying system and maintain it in a safe shutdown condition. The SSE is assumed to occur concurrent with the most severe Level A or B condition, including the failure of those non-safety grade components and or subsystems that are not designed to perform during an SSE (e.g., the MCO heating and cooling pump, the chilled water system, and MCS).

In addition to seismic loads the SSE may cause reactivity changes due to SNF differential motions. The magnitude and characteristic of the induced reactivity change will be further refined as the design proceeds. Following an SSE, the vacuum drying system is manually shut down by the operator if the MCS does not reach a trip setpoint. The responsible engineers for each subsystem and component shall call out the SSE combined event in their specifications. In addition, seismic aftershock shall be considered for those components and/or subsystems whose temperature would increase following an SSE. (An sxample is the MCO cooling system, where the aftershock temperature environment is hotter than the initial event.

NOTE: For detailed information on ground seismic response spectra, refer to WHC-SD-SNF-DB-010, Cold Vacuum Drying System Natural Phenomena Hazards. 
HNF-SD-SNF-DRD-002 REV 1

D-2 Design Basis Volcanic Ashfall

$+\quad$ (Frequency $=1 /$ Life per Drying Facility)

The cask-MCO and CVDF are returned to service following this event after repairs are made. No damage to the cask-MCO is expected from this event.

NOTE: For detailed information on the design basis for the volcanic ashfall, refer to WHC-SD-SNF-DB-010.

D-3 Design Basis Tornado

(Frequency $=1 /$ Life per Drying Facility)

The cask-MCO and CVDF are returned to service following this event after repairs are made.

NOTE: For detailed information on the design basis for the Tornado, refer to WHC-SD-SNF-DB-010.

\section{D-4 Design Basis Fire ** Bounding Event **}

(Frequency $=1 /$ Life per Drying Facility)

For this transient, all safety-related structures, systems, and components important to safety shall be capable of withstanding the effects of the design basis fire without loss of capability to perform their safety functions. This ensures the capability to shut down the vacuum drying system and maintain it in a safe shutdown condition. The design basis fire is assumed to occur concurrent with the most severe Level A or B condition, including the failure of those non-safety grade components and or subsystems that are not designed to perform during an design basis fire (e.g., the MCO heating and cooling pump, the chilled water system, and MCS).

The design basis fire shall consist of a gasoline or diesel fuel fire lasting 30 minutes, having a peak temperature of $800^{\circ} \mathrm{C}\left(1,472{ }^{\circ} \mathrm{F}\right)$, and an emissivity of 0.9 . The fire shall engulf the shipping cask. Following the fire, the cask shall reject heat to the environment by natural convection and thermal radiation with an emissivity of 0.9 . The ambient temperature shall be assumed to be $45^{\circ} \mathrm{C}\left(113^{\circ} \mathrm{F}\right)$. The detection of the fire shall be by the facility fire alarm system.

The system condition at the start of the event shall be the full vacuum case just following bulk water drain and with the $\mathrm{MCO}$ at $50^{\circ} \mathrm{C}\left(122^{\circ} \mathrm{F}\right)$. The fire shall cause the loss of system power, which causes the system valves to fail to fail-safe condition. This isolates the vacuum system, the inert gas system, and the cask-MCO temperature control system.

Water shall remain in the cask annulus during the fire and shall be expelled by pressure relief just as the post-fire-cooldown starts. 
NOTE: For detailed information on the design basis for the hypothetical fire event, refer to 10 CFR 71, "Packaging and Transportation of Radioactive Material."

D-5 Spent Nuclear Fuel Ignition during Vacuum Drying ** Bounding Event **. (Frequency $=1 /$ Life per Drying Facility)

For this transient, all safety-related structures, systems, and components important to safety shall be capable of withstanding the effects of the SNF ignition without loss of capability to perform their safety functions. This ensures the capability to shut down the vacuum drying system and maintain it in a safe shutdown condition. The SNF ignition is assumed to occur concurrent with the most severe Level A or B condition.

The system condition at the start of the event shall be the full vacuum case during the bulk water drain and with the $\mathrm{MCO}$ at $50^{\circ} \mathrm{C}\left(122^{\circ} \mathrm{F}\right)$. The SNF ignition will be detected by an increase in $\mathrm{MCO}$ total pressure above the normal setpoint. A secondary indication would be an increase in krypton levels at the gas analyzer (if present and operable). The system trip will isolate the vacuum system, initiate an inert gas system purge, and the cask-MCO temperature control system will initiate an emergency shutdown.

D-6 Hydrogen Ignition within the Multicanister Overpack during Vacuum Drying

** Bounding Event **

(Frequency $=1 /$ Life per Drying Facility)

For this transient, all safety-related structures, systems, and components important to safety shall be capable of withstanding the effects of the hydrogen ignition without loss of capability to perform their safety functions. This ensures the capability to shut down the vacuum drying system and maintain it in a safe shutdown condition. The hydrogen ignition is assumed to occur concurrent with the most severe Level A or B condition.

The system condition at the start of the event shall be the full vacuum case during the bulk water drain and with the $\mathrm{MCO}$ at $50^{\circ} \mathrm{C}\left(122^{\circ} \mathrm{F}\right)$. The hydrogen ignition within the $\mathrm{MCO}$ will be detected by an increase in MCO total pressure above the normal set point. $\mathrm{A}$ secondary indication would be an increase in hydrogen levels at the gas analyzer (if present and operable) prior to ignition. The system trip will isolate the vacuum system, initiate an inert gas system purge, and the cask-MCO temperature control system will initiate an emergency shutdown.

\section{REFERENCES}

10 CFR 71, "Packaging and Transportation of Radioactive Material," Code of Federal Regulations, as amended.

WHC-SD-SNF-DB-010, 1996, Cold Vacuum Drying System Natural Phenomena Hazards, Rev. 1, Westinghouse Hanford Company, Richland, Washington. 
HNF-SD-SNF-DRD-002 REV 1

This page intentionally left blank. 
HNF-SD-SNF-DRD-002 REV 1

APPENDIX E

SAMPLE STRUCTURES AND EQUIPMENT LIST FOR THE COLD VACUUM DRYING FACILITY 
HNF-SD-SNF-DRD-002 REV 1

This page intentionally left blank. 
Table E-1. Cold Vacuum Drying Facility Sample Structures and Equipment List.

\begin{tabular}{|c|c|c|c|c|c|c|c|c|}
\hline \multicolumn{2}{|c|}{ Components } & \multirow{2}{*}{$\begin{array}{c}\text { Safety } \\
\text { category } \\
\text { designation }\end{array}$} & \multicolumn{2}{|c|}{ Design criteria } & \multirow{2}{*}{ OCRWM requirement } & \multirow{2}{*}{$\begin{array}{l}\text { Design calculation } \\
\text { reference }\end{array}$} & \multirow{2}{*}{$\begin{array}{l}\text { Procurement } \\
\text { specification or } \\
\text { specification sheet } \\
\text { refercence }\end{array}$} & \multirow{2}{*}{ CVI reference } \\
\hline P\&ID & Conponent description & & $\begin{array}{l}\mathrm{NPH} \text { and } \\
\text { performance } \\
\text { category }\end{array}$ & $\begin{array}{l}\text { Codes and } \\
\text { standards }\end{array}$ & & & & \\
\hline \multicolumn{9}{|c|}{ Process bay and process water tank room structure } \\
\hline & Structure & & . & \multirow{10}{*}{ 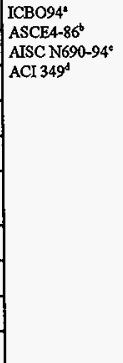 } & & & & \\
\hline H-1-82125, 126 & Precast wall panels & SS & 3 & & & & & \\
\hline $\mathrm{H}-1-82128,110$ & Roof & sS & 3 & & & & & \\
\hline $\mathrm{H}-1-82112$ & Doors & SS & 3 & & & & & \\
\hline H-1-82203 & Penetrations & ss & 3 & & & & & \\
\hline $\begin{array}{l}\text { H-1-82121 } \\
\text { through } 124\end{array}$ & Foundation and floors & ss & 3 & & . & & & \\
\hline $\mathrm{H}-1-82129,130$ & Structural framing & ss & 3 & & & & & \\
\hline $\mathrm{H}-1+82125,126$ & Precast wall panels & SS & 3 & & & & & \\
\hline $\mathrm{H}-1-82127$ & Second floor framing & ss & 3 & & & & & \\
\hline H-1-82131 & Stairs/mezzanires & ss & 2 & & & & & \\
\hline
\end{tabular}

"ICBO, 1994, Uniform Building Code, Intemational Conference of Building Officials, Whittier, California.

WB, 194, Seismic Analysis of Safety-Related Nuclear Structures and Commentary on Standard for Seismic Analysis of Safety-Related Nuclear Structures, ASCE-4-86, American Society of Civil Engineers, New York, New York.

'ANS1/AISC, 1994, Specification for the Design, Fabrication, and Erection of Steel Saffety-Related Structures for Nuclear Facilities, ANSVAISC N690-94, American Institute of Stcel Construction, Chicago, Illinois.

'ANSJ/ACI, 1990, Code Requirements for Nuctear Sofety Related Concrete Struatures, ANSWACI 349-90, American Concrete Institute, Detroit, Michigan.

CVI = certified vendor information.

$\mathrm{NPH}=$ ratural phenomena hazard.

OCRWM = U.S. Department of Energy, Office of Civilian Radioactive Waste Management.

$P \& D=$ piping and instrumentation drawing.

SS $=$ safety sionificant. 
HNF-SD-SNF-DRD-002 REV 1

This page intentionally left blank. 